Szegedi Tudományegyetem

Gyógyszerésztudományi Kar

Gyógyszeranalitikai Intézet

Kémia Doktori Iskola

\title{
CINKÓNA ÉS POLISZACHARID ALAPÚ KIRÁLIS \\ ÁLLÓFÁZISOK KÖLCSÖNHATÁSAINAK VIZSGÁLATA
}

\author{
Ph.D. ÉRTEKEZÉS
}

Készítette:

Bajtai Attila

Témavezető:

Prof. Dr. Ilisz István

Intézetvezető egyetemi tanár

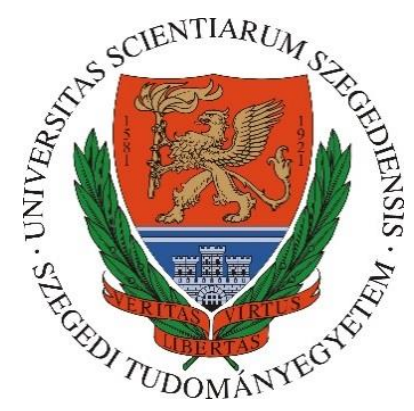

SZEGED

2021 
Tartalomjegyzék

RöVIDÍTÉSEK JEGYZÉKE ......................................................................................................... 1

1. BEVEZETÉS ............................................................................................................................................ 2

2. CÉLKITỦZÉS …………............................................................................................................. 3

3. IRODALMI ÁTTEKINTÉS........................................................................................................ 4

3.1. A kiralitás fogalma és jelentősége ....................................................................... 4

3.2. Az abszolút és relatív konfiguráció meghatározási módszereinek áttekintése .............5

3.2.1. Relatív módszerek az abszolút konfiguráció meghatározására ............................... 6

3.2.2. Abszolút módszerek az abszolút konfiguráció meghatározására............................ 6

3.2.3. A relatív konfiguráció meghatározásának lehetőségei ............................................ 8

3.3. Királis vegyületek kromatográfiás elválasztása......................................................... 9

3.4. A királis felismerés folyamata .............................................................................. 11

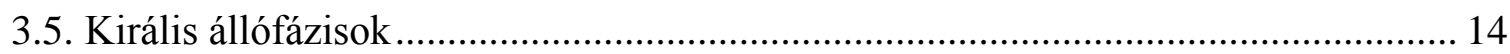

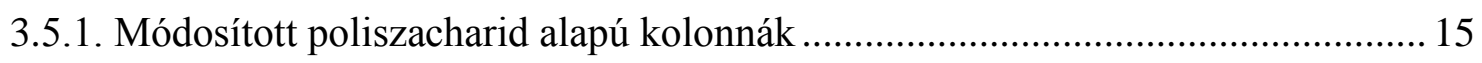

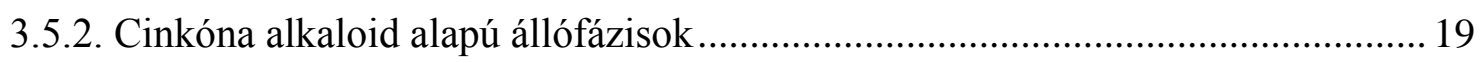

3.6. Az SFC technika alkalmazása királis vegyületek elválasztására................................ 21

3.6.1. Az SFC technika fontosabb jellemzöi .......................................................... 21

3.6.2. Az SFC technika alkalmazása királis komponensek elválasztására ..................... 23

3.7. A királis kromatográfia termodinamikai háttere...................................................... 25

3.7.1. A van’t Hoff egyenlet szerepe a királis kromatográfiában .................................... 25

3.7.2. A királis kromatográfia termodinamikai sajátságai .............................................. 27

3.8. A vizsgált vegyületek kémiai és biológiai jelentösége .............................................. 28

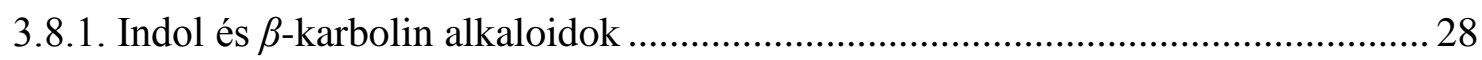

3.8.2. Tetrahidroizokinolin- és 1-naftol-származékok ……………………………....... 29

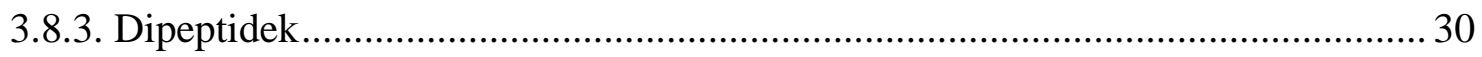

4. KÍSÉRLETI RÉSZ …......................................................................................................... 30

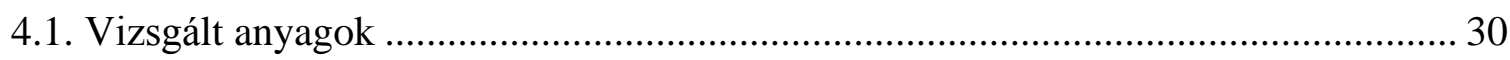

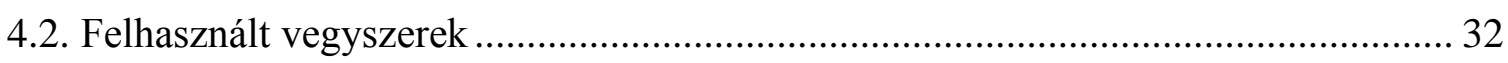

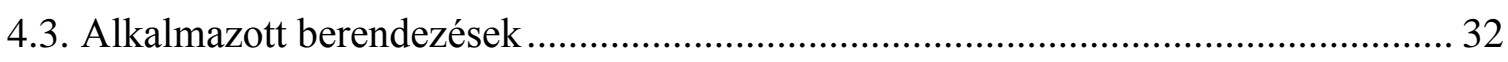

4.4. Alkalmazott folyadékkromatográfiás állófázisok ...................................................... 33

5. EREDMÉNYEK ÉS ÉRTÉKELÉSÜK .................................................................................. 34

5.1. A mozgófázis összetétel hatása a királis elválasztásra ................................................. 34 
5.1.1. A mozgófázis összetétel hatása a királis elválasztásra cinkóna alkaloid alapú szelektorok esetén

5.1.1.1. A kromatográfiás paraméterek változása a MeOH/MeCN 0-100 v/v tartományban

5.1.1.2. A mozgófázis összetétel változtatás hatásának összehasonlítása ikerionos és monoionos állófázisok esetén ................................................................... 36

5.1.1.3. A tetrahidrofurán tartalom hatása a kromatográfiás paraméterekre. 38

5.1.2. Az eluensösszetétel hatása az elválasztásra poliszacharid alapú szelektorok esetén 40

5.1.2.1. A mozgófázis alkotók anyagi minőségének hatása az elválasztásra. 41

5.1.2.2. A mozgófázis összetétel hatása a kromatográfiás paraméterekre .42

5.1.3. A mozgófázis összetétel hatása SFC technika esetén 43

5.1.3.1. Az SFC és HPLC technika mozgófázis összetétel hatásának összehasonlítása cinkóna alkaloid alapú szelektorok esetén 43

5.1.3.2. Az SFC mozgófázis alkotók anyagi minőségének vizsgálata poliszacharid alapú állófázisok esetén .45

5.1.3.3. Az SFC mozgófázis összetétel hatása az enantioszelektivitásra poliszacharid alapú állófázisok esetén .48

5.2. A mozgófázishoz adott ionos módosítók mennyiségének hatása az elválasztásra.... 49

5.2.1. A mozgófázishoz adott ellen- és kísérő ionok jelenlétének hatása. 50

5.2.2. A mozgófázishoz adott ellen- és kísérő ionok mennyiségének hatása az elválasztásra ikerionos és monoionos állófázisok esetén 52

5.2.3. Az SFC és HPLC mozgófázishoz adott ellen- és kísérő ionok hatásának összehasonlítása cinkóna alkaloid alapú állófázisok esetén. 54

5.3. A molekula szerkezet és a kromatográfiás jellemzők összefüggései 56

5.3.1. A cinkóna alkaloid alapú állófázisok szerkezetének hatása az elválasztásra 56

5.3.2. A poliszacharid alapú állófázisok szerkezete és a kromatográfiás viselkedés összefüggése 61

5.3.3. A királis szelektorok szerkezete és a kromatográfiás paraméterek összefüggése SFC technika esetén .65

5.3.3.1. Az SFC és HPLC technika összehasonlítása cinkóna alkaloid alapú állófázisok alkalmazásával

5.3.3.2. A poliszacharid alapú állófázisok vizsgálata SFC technika alkalmazásával 67 5.4. A hőmérséklet hatása a királis kromatográfiás rendszerekre 71 
5.4.1. A hőmérséklet hatása az elválasztásra cinkóna alkaloid alapú állófázisok esetén

5.4.2. A hőmérséklet hatása az elválasztásra poliszacharid alapú szelektorok esetén... 73

5.4.3. A hőmérséklet hatása az elválasztásra SFC technika esetén .75

5.4.3.1. A hömérséklet hatása SFC technika és cinkóna alkaloid alapú szelektorok alkalmazása esetén.

5.4.3.2. A hőmérséklet hatása SFC technika és poliszacharid alapú szelektorok alkalmazása esetén. .77

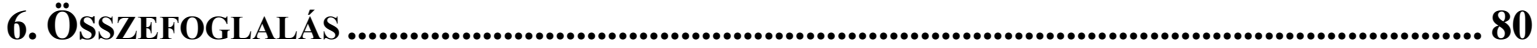

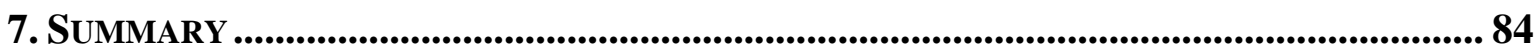

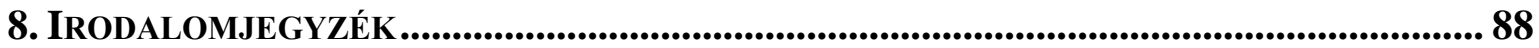

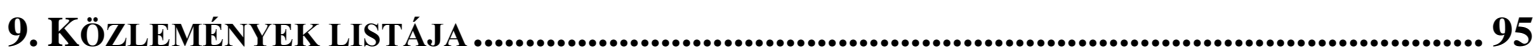

9.1. Az értekezés alapját képező közlemények ................................................................ 95

9.2. Az értekezés témájához kapcsolódó fel nem használt közlemények......................... 95

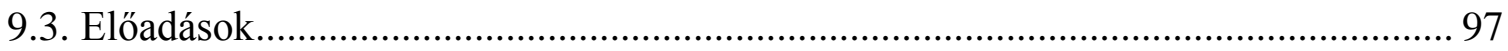

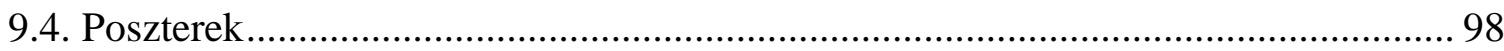

10. KöSZÖNETNYILVÁNíTÁS ................................................................................. 100

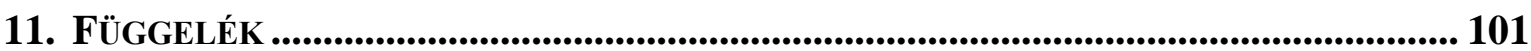




\section{RöVIDÍTÉSEK JEGYZÉKE}

AcOH: ecetsav

BuOH: 1-butanol

t-BuOH: 2-metil-propán-2-ol

CD: cirkuláris dikroizmus

DEA: dietil-amin

DEOA: dietanol-amin

EA: etil-amin

EtOH: etanol

FA: hangyasav

HPLC: nagyhatékonyságú folyadékkromatográfia

$\mathrm{MeCN}$ : acetonitril

$\mathrm{MeOH}$ : metanol

NMR spektroszkópia: mágneses magrezonancia spektroszkópia

NPM: normál fázisú mód

ORD: optikai rotációs diszperzió

PI: poláris-ionos

PIM: poláris-ionos mód

PO: poláris-szerves

PrOH: propán-1-ol

2-PrOH: propán-2-ol

QD: kinidin

QN: kinin

SFC: szuperkritikus folyadékkromatográfia (Supercritical Fluid Chromatography)

TEA: trietil-amin

THF: tetrahidrofurán

ZWIX: királis ikerionos ioncserélö 


\section{BEVEZETÉS}

Az élő rendszerek működésének megértése, megismerése és magyarázata évezredes múltra nyúló természetes emberi igény. Ennek része az emberi élet minőségét és tartalmát korlátozó megbetegedések, patológiás állapotok, melyek elleni küzdelem a gyógyszerkutatás egyik legjelentősebb motivációja. A gyógyszerkutatás értékteremtő folyamat, amely egyben a tudományos megismerés útja is. Eredményességéhez nélkülözhetetlen a legkülönbözőbb kutatási területek, mint a biológia, kémia és az orvostudományok folyamatosan fejlődő ismereteinek magas szintü integrálása. Így a gyógyszerfejlesztés egyszerre számos kutató összehangolt közös erőfeszítésén alapul. Ennek a folyamatnak része az analitikai kémia, melynek eredményeire a felfedező kutatástól a preés klinikai fejlesztésen át egészen a törzskönyvezésig szükség van. Mivel az élő szervezeteket felépítő molekulák királis rendszert alkotnak, pl.: aminosavak, fehérjék, cukrok, enzimek, polinukleotidok, így kiemelt figyelemmel kell vizsgálni a velük kölcsönhatásba kerülő szintén királis komponenseket.

Az enantiomerpárok kémiai és biológiai hatására jellemző, hogy az egyik enantiomer terápiás hatású (eutomer), míg a másik a terápiástól eltérő biológiai hatást fejthet ki (disztomer). A disztomer eltérő biológiai hatása széles spektrumon mozoghat, ez lehet csak egy kellemetlen mellékhatás, de akár toxikus metabolitot is eredményezhet. Ritka az olyan királis vegyület, melynek mindkét enantiomere hasonlóan kedvező terápiás hatást fejt ki. Ilyen kivételes molekula az ibuprofen, fájdalom, láz és gyulladáscsökkentő, valamint a fluxetin, antidepresszáns, melyek racém elegyként is használhatók. Azonban még az ilyen molekulák esetén sem teljesen azonos az enantiomerek farmakológiai viselkedése, mivel metabolizmusuk jelentősen eltér egymástól [1]. Ezért nélkülözhetetlen a gyógyszerfejlesztés során, hogy a végtermékben található összes királis komponens hatását alaposan megvizsgálják és mennyiségüket az évről-évre szigorodó hatósági követelményeknek megfelelve szabályozzák. Emellett királis molekulák esetén kiemelt fontosságú, hogy mind az alapanyagok, mind a gyártás köztitermékei megfelelö tisztasággal rendelkezzenek és ezt folyamatos ellenőrzés támassza alá. Ez a több mint 50 éves múltra visszatekintő elvárás kutatók generációit ösztönözte a lehető leghatékonyabb módszerek kifejlesztésére, ami a királis kromatográfiás technikák széleskörü elterjedéséhez vezetett.

A gyógyszeripar mellett számos más, az emberi életminőséget befolyásoló terület, mint az élelmiszeripar, kozmetikai ipar vagy a növényvédelem is felhasználja a királis kromatográfia eredményeit, ezért fontos, hogy a jövő perspektívái stabil alapokra épüljenek. 


\section{CÉLKITÜZÉS}

Munkám során célul tủztem ki folyadékkromatográfiás módszerek fejlesztését biológiai és gyógyszeripari szempontból fontos vegyületek sztereoizomerjeinek elválasztására, valamint eltérő müködési mechanizmusú királis kolonnák elválasztóképességének tanulmányozását változatos szerkezetủ vegyületekkel.

Vizsgálni kívántam:

- biológiailag aktív dipeptidek elválasztását cinkóna alkaloid alapú állófázisokon nagyhatékonyságú folyadékkromatográfiával (HPLC),

- bázikus és amfolit indol analógok elválasztását cinkóna alkaloid alapú ikerionos, valamint módosított poliszacharid alapú állófázisokon HPLC és szuperkritikus folyadékkromatográfia (SFC) alkalmazásával,

- 1,2,3,4-tetrahidroizokinolin-vázas és 1-naftol vegyületek és szerkezeti analógjaik elválasztását módosított poliszacharid alapú állófázisokon HPLC és SFC technikával.

A vizsgált vegyületek kromatográfiás paramétereinek meghatározásán keresztül értelmezni kívántam az eluensösszetétel és a poláris módosító (alkohol) minőségének és mennyiségének hatását az elválasztásra. A vegyületek szerkezetének rendszerezett változtatásával következtetéseket kívántam levonni a vegyület és a királis szelektor között kialakuló kölcsönhatásokra. Az ioncserélő állófázisok esetén a mozgófázis sav- és bázistartalmának változtatásával az ellenion koncentráció elválasztásra gyakorolt hatását kívántam tanulmányozni. Emellett célom volt a hőmérséklet kromatográfiás paraméterekre gyakorolt hatásának tanulmányozásával az elválasztási mechanizmus termodinamikai hátterének mélyebb megismerése. 


\section{IRODALMI ÁTTEKINTÉS}

\subsection{A kiralitás fogalma és jelentősége}

A szénatom tetraéderes vegyérték-orintációjának felismerése 1894-ben a kémia kétdimenziós szemléletét háromdimenziósra terjesztette ki és egyben a sztereokémia megszületéséhez vezetett. A sztereokémiai fogalmak pontos definiálása nélkülözhetetlen a molekulák térszerkezetével kapcsolatos következtetések megértéséhez. A sztereokémia egyik legfontosabb feladata a molekulák lehetséges szerkezeti, konfigurációs és konformációs izomerjeinek a meghatározása. Szerkezeti izoméria áll fenn két vegyület esetén, ha molekulaképletük azonos, de az atomok kapcsolódási sorrendje különböző a molekulákban. Ha az atomok kapcsolódási sorrendje megegyezik és egymással fedésbe nem hozható tükörképei egymásnak, akkor enantiomerek, ha tükörképi viszony nem tapasztalható, akkor diasztereomer a viszonyuk. A disztereomerek fizikai és kémiai tulajdonságai eltérnek egymástól, míg az enantiomerek akirális környezetben nem különböztethetők meg egymástól. Enantiomer viszony csak királis szerkezet esetén fordulhat elő. A kiralitás fogalmát Lord Kelvin ír Nobel-díjas fizikus használta először 1904ben, miszerint királis egy molekula, ha annak síktükörben látható tükörképe nem hozható fedésbe az eredetivel. Tehát egy molekula királis, ha nem tartalmaz tükrözési szimmetriatengelyt.

\section{A kiralitás négy fő típusba sorolható a királis molekularész szerkezete alapján [2]:}

- Centrális: a királis atomhoz legalább négy különböző atom vagy atomcsoport kapcsolódik (a nemkötő elektronpár is tekinthető egy kapcsolódó „atomnak”), (pl.: aminosavak).

- Axiális: a molekula kiralitástengellyel rendelkezik, amely körül a szubsztituensek úgy helyezkednek el a térben, hogy a molekula nem hozható fedésbe a tükörképével (pl.: allének, spiro vegyületek).

- Planáris: a molekula két, egymással nem azonos síkban levő diszimmetrikus gyürüt tartalmaz, amelyek az öket összekapcsoló kémiai kötés mentén nem tudnak könnyen elfordulni (pl.: aromás fémkomplexek).

- Helikális: a molekula nem síkbeli csavarmenettel rendelkezik (pl.: DNS kettős hélixe, keményítő).

Ezek közül leggyakrabban a centrális kiralitás fordul elő a természetben. Azonban fontos megjegyezni, hogy a királis centrum jelenléte a molekulában nem szükséges és nem elégséges feltétele a kiralitásnak. $\mathrm{N}$ darab aszimmetriacentrumot tartalmazó molekula esetén 
a lehetséges sztereoizomerek száma $2^{\mathrm{N}}$. Azokat a vegyületeket, amelyek csak egy kiralitáscentrum konfigurációjában térnek el egymástól, epimereknek nevezzük.

A kiralitás számos formában megnyilvánulhat, például előfordulhat két vagy három dimenzió esetén [3]. Továbbá a kiralitás következményei tapasztalhatók molekuláris, mikroszkópikus és makroszkópikus szinten [4], valamint a természetben található élő (1. ábra) és élettelen formák (pl.: kvarc kristály) szerkezetében is [3, 5].
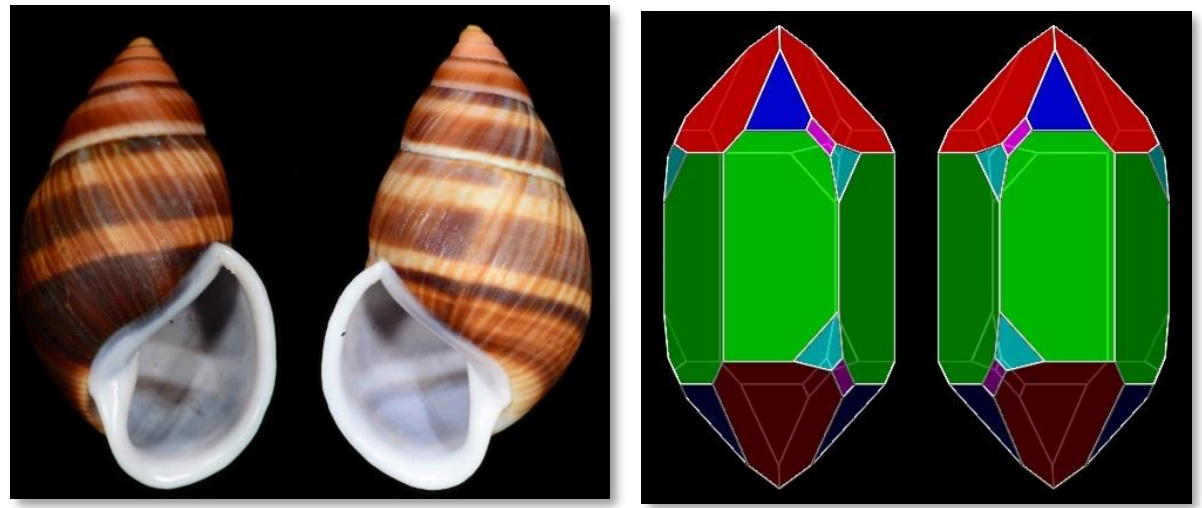

1. ábra Kiralitás előfordulása a természetben. Enantiomer szerkezetü csigaházak és enantiomer kvarc kristály elemi cellák

\subsection{Az abszolút és relatív konfiguráció meghatározási módszereinek áttekintése}

Királis molekulák esetén az egy enantiomerből álló tiszta anyag optikailag aktív, vagyis a lineárisan polarizált fény síkját elforgatja. A másik enantiomerből álló tiszta anyag ellentétes irányba forgatja el a fényt, ezért a két enantiomert egyenlő mennyiségben tartalmazó racém elegy optikailag inaktív, mivel az ellentétes irányú forgatások kompenzálják egymást. Fontos megjegyezni, hogy az optikai forgatóképesség nincs közvetlen kapcsolatban a molekula valós térszerkezetével, másnéven az abszolút konfigurációjával. Az abszolút konfiguráció jelölésére legelterjedtebben a Cahn-Ingold-Prelog rendszer $(R) /(S)$ jelölése használt. A jelölés lényege, hogy az aszimmetriacentrumhoz kapcsolódó atomokat, illetve atomcsoportokat a periódusos rendszerben elfoglalt helyük alapján rangsorolni kell, majd a térszerkezetet, illetve annak modelljét a rangsor alapján utolsó helyen álló atommal vagy atomcsoporttal ellentétes oldalról szemlélve, meg kell határozni a többi atom vagy atomcsoport sorrendszerinti körüljárásának irányát. Az óramutató járásával azonos körüljárási irány jelzése $R$ (,,rectus”), az ellentétesé pedig $S$ (,sinister”). Azonban fontos kiemelni, hogy ez a jelölésmód csak a már meghatározott abszolút konfiguráció leírására szolgál, nem pedig a valódi térszerkezet megállapítására. Továbbá a Cahn-Ingold-Prelog rendszer merev formalizmusa miatt két azonos konfigurációjú molekula esetén is lehet ellentétes a jelölés. Ez megfigyelhető az L- $(S)$-szerin és L- $(R)$-cisztein vagy a szénhidrátok 
gyürüs és nyílt láncú formái esetén. Ezért az aminosavak és a szénhidrátok esetében az abszolút konfiguráció helyett gyakran a relatív konfiguráció használatos. A relatív konfiguráció leírására jellemzően a Fischer által a glicerinaldehid konfigurációjára alapozott L (,laevus”-bal) és D (,dexter”-jobb) jelölést alkalmazzák.

A relatív konfigurációt kémiai átalakításokkal meg lehet határozni, azonban a valódi térszerkezetet csak kémiai módszerekkel nem lehetséges megállapítani. Egy optikailag aktív anyag abszolút konfigurációját először 1951-ben Bijvoet és munkatársainak sikerült meghatároznia, a D-borkősav röntgendiffrakciós szerkezetvizsgálatával [6]. Előtte csak a Dglicerinaldehidre visszavezetett Fischer-féle relatív konfiguráció alapján volt lehetséges a térszerkezet vizsgálata. Azonban Bijvoeték eredményeinek köszönhetően egyszerre az összes relatív konfigurációval rendelkező molekula valós térszerkezete ismert lett.

Ha a relatív konfiguráció ismert, akkor az abszolút konfiguráció meghatározása történhet relatív vagy abszolút módszerekkel [7]. A relatív módszereknél minden esetben szükség van egy összehasonlítási alapra, ami lehet egy királis nem racém anyag vagy ismert konfigurációjú referencia molekula.

\subsubsection{Relatív módszerek az abszolút konfiguráció meghatározására}

- Kémiai korreláció: ismert abszolút konfigurációjú vegyületté alakítás olyan reakciókkal, melyek nem befolyásolják, vagy csak sztereoszelektíven változtatják meg a kiralitásért felelős molekularészt.

- NMR spektroszkópiai módszerek: diasztereomerek képzése ismert konfigurációjú királis reagensekkel (pl.: Mosher reagens) és a kapott diasztereomerek konfigurációjának meghatározása a mágneses anizotrópia miatt kialakuló kémiai eltolódás különbségek alapján [8].

- Röntgendiffrakció: abban az esetben tekinthető relatív módszernek, ha a vizsgálandó vegyület tartalmaz legalább egy ismert abszolút konfigurációjú királis molekularészt, amihez a többi királis elem konfigurációja viszonyítható. A röntgendiffrakciós analízis ilyen célú alkalmazásához gyakran szükséges származékképzéssel nehéz atom (pl. bróm) vagy ismert konfigurációjú csoport bevitele, melynek jelenléte megfelelő fáziskülönbséget vagy referenciát ad az abszolút konfiguráció meghatározásához [9]

\subsubsection{Abszolút módszerek az abszolút konfiguráció meghatározására}

A referencia anyag nélküli abszolút konfiguráció meghatározása többek között történhet anomális röntgendiffrakcióval, kristálymorfológia adalékokkal történő módosításának vizsgálatával vagy kiroptikai módszerekkel [10]. 
Az anomális röntgendiffrakció (Bijvoet módszer) esetén a vizsgált anyag kristályában jellemzően kénnél nehezebb atom jelenléte szükséges. Olyan röntgensugárzás hatására, amelynek hullámhossza közel van a nehéz atom abszorpciós határához, fáziskülönbség tapasztalható, aminek következtében a diffrakciós mintázat centrális szimmetriája megszünik, vagyis a centrális szimmetria alapján összetartozó foltpárok intenzitása különbözővé válik [11].

A kristálymorfológia adalékokkal történő módosítása esetén a kristálynövekedés irányát a vegyület polaritásától szerkezetileg vagy konfiguráció tekintetében különböző adalékok megváltoztathatják, ami a növekedés sebességének megváltozását okozza. Ez valamilyen irányba jól megfigyelhető eltérést eredményez, amiből a konfiguráció meghatározható [12].

A kiroptikai módszerek alapja, hogy a királis, nem racém anyag eltérően hat kölcsön a fény jobbra és balra cirkulárisan polarizált komponenseivel.

\section{Az abszolút konfiguráció meghatározására használható legfontosabb kiroptikai módszerek $[11,13]$ :}

- Optikai rotációs diszperzió (ORD): az optikai forgatóképesség függése a fény hullámhosszától UV-látható tartományban.

- Elektronikus cirkuláris dikroizmus (ECD): az anyag moláris abszorbancia különbségének változása az UV-látható tartományban.

- Fluoreszcens fénnyel detektált cirkuláris dikroizmus (FDCD): a moláris abszorbancia különbség változásának követése az UV-látható tartományban fluoreszcens detektálással.

- Vibrációs cirkuláris dikroizmus (VCD): a molekula rezgési átmenetéhez kapcsolódó abszorpciós különbség mérése az infravörös tartományban.

- Raman optikai aktivitás (ROA): a Raman spektroszkópia királis megfelelője.

A CD-spektroszkópia egy molekula alapállapotból elektronikusan gerjesztett állapotba való átmenetéhez szükséges energiát és a gerjesztés valószínűségét méri. CD-spektroszkópia esetén az optikailag aktív közegen áthaladó cirkulárisan balra, ill. jobbra polarizált fény egymáshoz képest eltérő sebességgel terjednek, azaz a közeg törésmutatója eltérő a két fény esetén. Továbbá az optikailag aktív közeg különböző mértékben abszorbeálja a cirkulárisan balra, ill. jobbra polarizált fényt, így a síkban polarizált fény áthaladva az optikailag aktív közegen elliptikusan polarizálttá válik. A két cirkulárisan polarizált fény összetevő eltérő mértékü abszorpcióját, illetve a kilépő fény ezzel kapcsolatos ellipticitását cirkuláris dikroizmusnak nevezzük. A cirkulárisan polarizált fény abszorbancia különbségét a 
hullámhossz függvényében mérve kapjuk meg az adott anyagra jellemzö CD-spektrumot [11].

Az optikai rotációs diszperzió az optikai forgatóképesség függése a fény hullámhosszától. Az ORD-spektropolariméter és polariméter müködése között nincs elvi különbség. Azonban a CD-jelenség csak az abszorpciós sáv környezetében észlelhető, míg az ORD-spektrum a távoli hullámhossz tartományban is mérhetö, mivel fénytörést gyakorlatilag minden hullámhosszúságú fény mutat. Az ORD és a CD-spektrum egymásba átszámítható.

A Raman optikai aktivitás (ROA) a rezgési optikai aktivitások közé tartozik [14]. A Raman-szórást legegyszerübben a fény, mint elektromágneses sugárzás elektromos tere és a molekula polarizálhatósága közötti kölcsönhatásként lehet leírni. A ROA azon alapszik, hogy a királis molekulák enantiomerei eltérő polarizálhatósági tenzora miatt különböző intenzitással szórják a cirkulárisan polarizált fényt [15]. Az intenzitáskülönbségek hullámszám függvényében rögzített spektruma lehetővé teszi a vizsgált vegyület királis konfigurációjának jellemzését.

A fentebb bemutatott módszerek abszolút konfiguráció meghatározására csak a megfelelő elméleti számítások és modellek használatával alkalmazhatók. Így szemi-empirikus és kvantumkémiai modellezést egyaránt felhasználnak, hogy a mért spektrumokat elméleti alapon is leírhassák [16]. A számításokkal meghatározott spektrumok és a kísérleti adatok összehasonlításával meghatározható az abszolút konfiguráció [17].

Természetesen mindegyik módszer rendelkezik elönyökkel és korlátokkal egyaránt. Például a kiroptikai módszerek esetén a vizsgált molekula konformáció eloszlását vagy preferált oldatbeli konformációját ismerni kell, ami a változatos konformációval rendelkező komponensek vizsgálatánál jelentős kihívást jelenthet [13]. Ezzel szemben a röntgendiffrakció esetén a szilárd fázisban az adott enantiomer egyértelmüen meghatározott, és még az egyes molekulák relatív orientációja is ismert a rácsban. Kiroptikai módszerekkel nem kristályos vegyületek is vizsgálhatók, míg a röntgendiffrakciós vizsgálatokhoz elengedhetetlen a kristályosítás. Az ECD módszer alkalmazásának feltétele a megfelelö kromofor jelenléte a molekulában, aminek hiánya a VCD és ROA módszereknél nem jelent akadályt.

\subsubsection{A relatív konfiguráció meghatározásának lehetőségei}

A relatív konfiguráció számos módszerrel meghatározható. Ezek egyaránt alkalmazhatók a molekulán belüli, illetve a molekulák közötti relatív konfiguráció meghatározására. Mivel az abszolút konfiguráció meghatározására alkalmas kísérleti módszerek csak korlátozottan 
állnak rendelkezésre, ezért a relatív konfiguráció meghatározása továbbra is fontos szerkezetvizsgálati feladat.

\section{A relatív konfiguráció meghatározására széles körben használt módszerek:}

- röntgenkrisztallográfia,

- szimmetriatulajdonságokon alapuló technikák,

- diasztereomereken keresztül történő korreláció (konfrontációs analízis),

- kiroptikai és NMR (pl.: NOE) spektroszkópiai módszerek,

- aszimmetriás szintézisek,

- a kiralitáscentrumhoz közvetlenül nem kapcsolódó kötések kémiai átalakítása,

- kiralitáscentrumot érintő ismert sztereokémiájú reakciók,

- korreláció kváziracemátokon keresztül.

Ezek közül az utolsó három technika napjainkban inkább csak történeti szempontból jelentős. Az aszimmetriás szintézisek csak korlátozottan használhatók ilyen célra, jelentőségük inkább az enantiomertisztaság vizsgálatában jelenik meg [18].

Összefoglalásként kijelenthető, hogy minden esetben használható módszer nem ismert sem a relatív sem az abszolút konfiguráció megállapítására, ezért a gyakorlatban hasznos számos szerkezet meghatározó módszer sokoldalú ismerete.

\subsection{Királis vegyületek kromatográfiás elválasztása}

A sztereoizomerek konfiguráció vizsgálatához és a királis molekulák gyakorlati hasznosításához szükséges az enantiomerek királisan tiszta formára hozása. Ez számos módon megvalósítható (2. ábra) [19], azonban előnyös tulajdonságai miatt mind az analitikai, mind az ipari felhasználás esetén a kromatográfiás technika vált a legelterjedtebbé [20]. Ezért a királis vegyületek kromatográfiás elválasztása kiemelt jelentőségüvé vált az elmúlt három évtizedben.

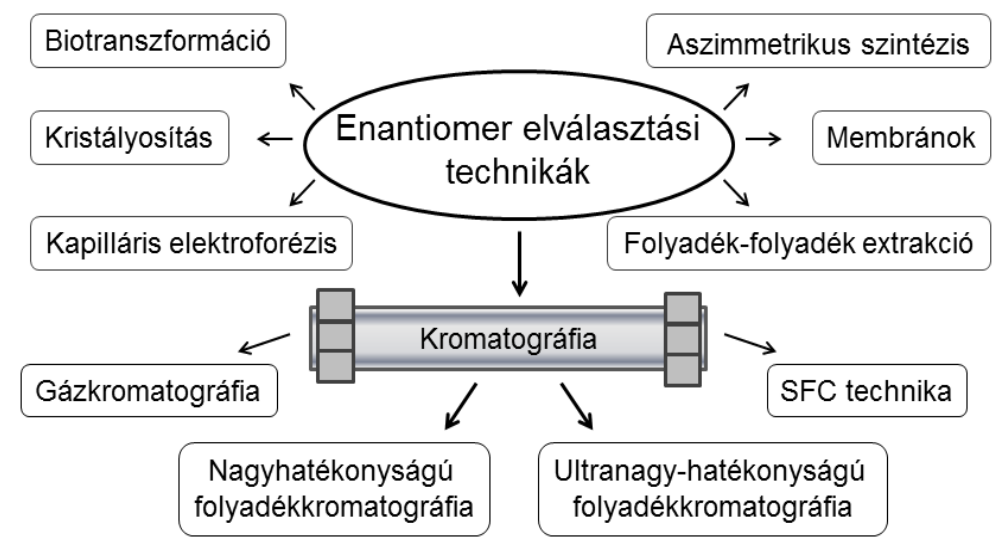

2. ábra Királis vegyületek elválasztási lehetőségei 
Akirális környezetben az enantiomerek fizikai és kémiai tulajdonságaik megegyeznek, így azok elválasztásához nélkülözhetetlen, hogy királis környezetnek legyenek kitéve. Ezért az enantiomerek kromatográfiás elválasztása minden esetben diasztereomerpár képzésén alapul. Az 1. és 2. egyenlet bemutatja, az állófázis felületén reverzibilis módon kialakuló átmeneti diasztereomerpár általános képződési folyamatát.

$$
\begin{aligned}
& (R)-\mathrm{Sz}+(S)-\mathrm{E} \stackrel{K_{S}}{\rightleftharpoons}[(R)-\mathrm{Sz}---(S)-\mathrm{E}] \\
& (R)-\mathrm{Sz}+(R)-\mathrm{E} \stackrel{K_{R}}{\rightleftharpoons}[(R)-\mathrm{Sz}---(R)-\mathrm{E}]
\end{aligned}
$$

Az 1-es és 2-es egyenletekben az $R$ konfigurációjú szelektort $(R)$-Sz, az $S$ vagy $R$ konfigurációjú enantiomert $(S)$-E és $(R)$-E, az $S$ vagy $R$ konfigurációjú enantiomer által a szelektorral kialakított átmeneti diasztereomer komplex egyensúlyi állandóját $K_{S}$ és $K_{R}$ jelöli. A különböző retenciós viselkedés a diasztereomerpár képződéséhez vezető reakciók egyensúlyi állandóinak eltérő értékéből adódik.

A diasztereomerpár képzés alapján két folyadékkromatográfiás módszer különböztethető meg, a közvetlen és a közvetett technika. Közvetlen az elválasztás, ha a vizsgált komponens diasztereomerpárt képez a mozgófázis vagy az állófázis királis komponensével [21]. Ezzel szemben közvetettnek tekinthető az elválasztás, ha a vizsgált komponensek előszőr királis származékképzővel reagálnak, majd ezt követően diasztereomer formában kerülnek elválasztásra az állófázissal [22]. A közvetett és a közvetlen módszerek előnyeit és hátrányait

\begin{tabular}{|c|c|}
\hline Közvetlen módszerek & Közvetett módszerek \\
\hline \multicolumn{2}{|c|}{$\begin{array}{ll}\text { Előnyök } \\
\end{array}$} \\
\hline $\begin{array}{l}\text { A királis szelektor enantiomer tisztasága } \\
\text { nem kritikus. }\end{array}$ & $\begin{array}{l}\text { Akirális kolonna is használható, ami } \\
\text { olcsóbb, mint a királis. }\end{array}$ \\
\hline $\begin{array}{l}\text { Racemizáció nem valószínü az analízis } \\
\text { során. }\end{array}$ & $\begin{array}{l}\text { Az elúciós sorrend következtethetö, illetve } \\
\text { megfordítható. }\end{array}$ \\
\hline $\begin{array}{l}\text { Funkciós csoportot nem tartalmazó } \\
\text { racemátok is elválaszthatók. }\end{array}$ & A detektálás alsó határa csökkenthető. \\
\hline Preparatív célra is használható. & A szelektivitás növelhető (pl.: előtisztítás). \\
\hline $\begin{array}{l}\text { A hőmérséklet változtatása gyakran } \\
\text { kedvező az elválasztás szempontjából. }\end{array}$ & A módszerfejlesztés kevésbé időigényes. \\
\hline Általában egyszerübb a mintaelőkészítés. & \\
\hline $\begin{array}{l}\text { Az enantiomerek moláris abszorbanciája } \\
\text { azonos. }\end{array}$ & \\
\hline
\end{tabular}
az 1. táblázat foglalja össze [23].

1. táblázat A közvetlen és a közvetett királis folyadékkromatográfiás módszerek összehasonlítása 


\begin{tabular}{|c|c|}
\hline Közvetlen módszerek & Közvetett módszerek \\
\hline \multicolumn{2}{|c|}{ Hátrányok } \\
\hline $\begin{array}{l}\text { Az elméleti tányérszám általában kisebb, } \\
\text { mint közvetett esetben. }\end{array}$ & $\begin{array}{l}\text { A származékképző enantiomer tisztasága } \\
\text { kritikus. }\end{array}$ \\
\hline $\begin{array}{l}\text { A deszorpció kinetikája egyes esetekben } \\
\text { lassú. }\end{array}$ & $\begin{array}{l}\text { A származékképzés során racemizáció } \\
\text { léphet fel. }\end{array}$ \\
\hline $\begin{array}{l}\text { Az elúciós sorrend és a királis } \\
\text { kölcsönhatások háttere nincs teljesen } \\
\text { felderítve. }\end{array}$ & $\begin{array}{l}\text { A származékképzés során előfordulhat } \\
\text { „kinetikai rezolúció”. }\end{array}$ \\
\hline Nincs általánosan használható állófázis. & $\begin{array}{l}\text { A képzödött diasztereomerek moláris } \\
\text { abszorbanciája különböző lehet. }\end{array}$ \\
\hline $\begin{array}{l}\text { A királis állófázisok nagyon érzékenyek az } \\
\text { elválasztás körülményeinek változtatására. }\end{array}$ & $\begin{array}{l}\text { A reagens feleslege és a melléktermékek } \\
\text { zavaró csúcsként jelentkezhetnek. }\end{array}$ \\
\hline A királis állófázisok költségesek. & $\begin{array}{l}\text { Az enantiomerek visszanyerése további } \\
\text { müveleteket igényel. }\end{array}$ \\
\hline & $\begin{array}{l}\text { A származékképzés jelentősen } \\
\text { megnehezítheti a mintaelőkészítést. }\end{array}$ \\
\hline
\end{tabular}

1. táblázat (folytatás) A közvetlen és a közvetett királis folyadékkromatográfiás módszerek összehasonlítása

\subsection{A királis felismerés folyamata}

A királis vegyületek élő szervezetekben kifejtett eltérő hatásmechanizmusait előszőr 1933-ban Easson és Stedman kísérelte meg sztereoszelektív kölcsönhatásokra épülő szerkezeti modellel magyarázni. Hárompontos illeszkedési modelljük alapján az optikailag aktív molekulák és a kölcsönható komponensek, esetükben a fehérje receptor között akkor alakul ki stabilis kapcsolat, mely az enantiomer megkülönböztetést lehetővé teszi, ha legalább három konfiguráció-függő ponton vonzó kölcsönhatás lép fel. Ezt a modellt az elválasztástechnika már 1952-ben használta optikailag aktív vegyületek (aromás aminosavak) vékonyrétegkromatográfiás elválasztása során kapott eredményeinek magyarázatára [24]. Újabb ismeretek alapján kijelenthető, hogy a királis felismeréshez nincs szükség egyszerre három vonzó kölcsönhatásra [25, 26]. Akár két taszító kölcsönhatás is részt vehet a sztereoszelektivitás kialakításában, ha a harmadik kölcsönhatás által kifejtett vonzás képes legalább az egyik átmeneti diasztereomert létrehozni [27]. Korábban Pirkle és Pochapsky fogalmazta meg, hogy a királis felismerés kialakulásához, elég ha a három kölcsönható pont közül csak egy sztereoszelektív [28]. A hárompontos illeszkedés modelljét a 3. ábra mutatja be. 


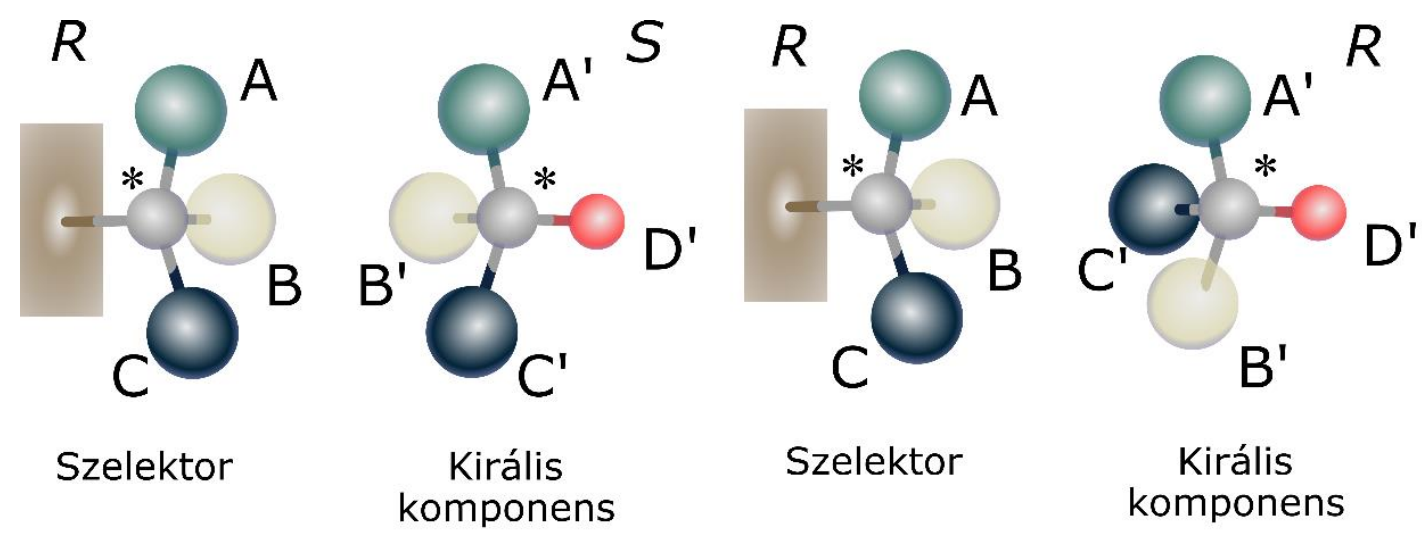

3. ábra A királis felismerést leíró hárompontos illeszkedés modellje

Ha az enantiomer és a szelektor által alkotott átmeneti diasztereomerpár kialakulásában két- vagy háromdimenziós (pl.: elágazás nélküli lánc, kondenzált gyürü) szerkezeti elemeket tartalmazó molekula vesz részt, akkor egy molekularész akár több kölcsönható helyet is biztosíthat [29]. Fontos figyelembe venni, hogy az adott enantiomer és az állófázis között kialakuló eltérő típusú kölcsönhatások típusuktól függően egyszerre több ponton is kifejthetik hatásukat. Vagyis, míg a hidrogénhíd csak egy-egy ponton fejti ki hatását az elválasztandó molekula és a szelektor között, addig a $\pi$ - $\pi$ kötés és a dipólus-dipólus kölcsönhatás egyszerre több kölcsönhatási pontot is biztosít a szükséges háromból.

Az enantiomer és az állófázis között kialakuló bármely nem kovalens kölcsönhatás részt vehet a királis felismerés létrejöttében, így a fellépő kölcsönhatások hatóereje és iránya jelentősen befolyásolja az átmeneti diasztereomerpár stabilitását. A diasztereomerpár létrejötteért felelős kölcsönhatások eltérő hatótávolsága a királis felismerésben betöltött funkciójukat is meghatározza. A távolra ható kölcsönhatások teszik lehetővé, hogy az enantiomer és a szelektor egymás közelébe jusson, és meghatározzák a retenciós tulajdonságokat. Azonban a nagy távolságra ható kölcsönhatások jellemzően nem sztereoszelektívek, ezért az enantiomerek sikeres elválasztásához önmagukban nem elegendők. A kisebb hatótávolságú kölcsönhatások általában sztereoszelektívek és a diasztereomerpár stabilizálásában meghatározók [30]. Azonban fontos kiemelni, hogy a rövid hatótávolságú kölcsönhatások érvényesülése gyakran függ az elválasztandó komponens és a szelektor geometriájától, ezért a királis felismerésért felelős csoportok térszerkezetének csekély megváltoztatása az elválasztás hatékonyságának jelentős módosulásához vezethet. A szelektorhoz vagy az elválasztandó komponenshez eltérö térkitöltésü csoportot kapcsolva az enantioszelektivitás jelentős változása egyértelmüen alátámasztja ezt a sajátságot [21,31]. A királis felismerésben meghatározó kölcsönhatások legfőbb sajátságait a 2. táblázat mutatja be [32]. 


\begin{tabular}{|cccc|}
\hline Kölcsönhatás típusa & Hatóerő & Irányultság & Hatótávolság \\
\hline $\begin{array}{c}\text { Coulomb vagy elektromos } \\
\text { kölcsönhatás }\end{array}$ & Nagyon erös & $\begin{array}{c}\text { Vonzó vagy } \\
\text { taszító }\end{array}$ & Nagy \\
\hline Hidrogénhíd & Erös & Vonzó & Közepes \\
\hline Sztérikus gátlás & $\begin{array}{c}\text { Nagyon erőstöl } \\
\text { nagyon gyengéig }\end{array}$ & Taszító & Kicsi \\
\hline $\boldsymbol{\pi}$ - $\boldsymbol{\pi}$ kölcsönhatás & Erös & Vonzó & Közepes \\
\hline $\begin{array}{c}\text { Ion-dipólus kölcsönhatás } \\
\text { Dipólus-dipólus } \\
\text { kölcsönhatás }\end{array}$ & Erős & Vonzó & Kicsi \\
\hline $\begin{array}{c}\text { Dipólus-indukált dipólus } \\
\text { kölcsönhatás }\end{array}$ & Gyenge & Vonzó & Kicsi $\left(1 / \mathrm{d}^{3}\right)$ \\
\hline $\begin{array}{c}\text { London-féle diszperziós } \\
\text { vagy van der Waals erők }\end{array}$ & Nagyon gyenge & Vonzó & Nagyon kicsi $\left(1 / \mathrm{d}^{6}\right)$ \\
\hline
\end{tabular}

2. táblázat A királis felismerésben szerepet játszó molekuláris kölcsönhatások és jellemző tulajdonságaik, d: két komponens közötti távolság

Az enantiomer és a királis állófázis szelektorából álló átmeneti diasztereomerpár stabilitását növelő sajátság:

- a sztérikus megfelelőség, amikor a forma és a méret komplementer,

- az elektrosztatikus illeszkedés, melynek során a töltéssel rendelkező funkciós csoportok térbeli helyzete és iránya kedvező,

- a hidrofób illeszkedés, amikor a lipofil molekularészek egymáshoz közel kerülve a hidrofób régiók intermolekuláris kapcsolódását eredményezik,

- dinamikus és indukált megfelelőség, azaz a konformációs viszonyok megváltozása a kedvezőbb kötések kialakításához [33],

- az enantiomer és a szelektor felszín szűk környezete kölcsönösen kiegészíti egymást [27].

A felsorolt tulajdonságok alapján a legtöbb esetben a nem kovalens kölcsönhatások határozzák meg a királis felismerés hatékonyságát. Ebből következően az eluens összetétel meghatározó jelentőségű a királis felismerés folyamatában. A mozgófázis összetételének megváltoztatása lehetővé teszi az átmeneti diasztereomerpár stabilitásának és a királis felismerés mechanizmusának befolyásolását. Az elválasztandó komponensek és a szelektor felületét borító szolvátburok vastagsága és polaritása jelentős hatást gyakorolhat a sztereoszelektív kölcsönhatásokra [25]. Például a nagyon poláris oldószerek képesek csökkenteni az elektrosztatikus kölcsönhatások erejét, ezzel szemben a hidrofób környezet jelentősen erősíthet rajtuk. Emellett érdemes kiemelni, hogy a hidrofób kölcsönhatások csak 
vizes mozgófázisok (pl. fordított fázis, hidro-organikus elválasztás) esetében tudnak érvényesülni. Az ionos kölcsönhatások még poláris protikus oldószer esetén is viszonylag erősek, azonban megfelelő só vagy puffer rendszer használatával jól szabályozható a hatásuk. Az elmúlt években ugyan többen is megkérdőjelezték érvényességét, azonban a felsorolt tulajdonságok és szempontok alapján, a királis felismerés leírására a mai napig széles körben elfogadott és használt a hárompontos illeszkedés modellje [34].

\subsection{Királis állófázisok}

A királis felismerésben szerepet játszó fontosabb tényezők mélyebb megismerése változatos szerkezetü királis állófázisok fejlesztését ösztönözte [35-37].

$\mathrm{Az}$ állófázisok eredetük szerint lehetnek természetes vagy mesterséges alapúak. A két csoport között van átfedés, mivel a természetes kiindulási vegyületeket jellemzően a sztereoszelektivitás növelése érdekében módosítva alkalmazzák, illetve a ligandumcserélő és donor-akceptor típusú állófázisok gyakran tartalmaznak természetes aminosavakat. A gyakorlati jelentőséggel rendelkező királis állófázisokat, szelektoraikat és a meghatározó kölcsönhatásokat a 3. táblázat foglalja össze [32].

\begin{tabular}{|c|c|c|c|}
\hline & Állófázis típusa & Szelektor & $\begin{array}{c}\text { Meghatározó } \\
\text { kölcsönhatások }\end{array}$ \\
\hline \multirow{6}{*}{ 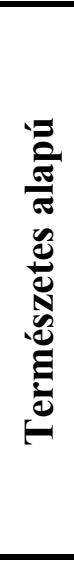 } & $\begin{array}{c}\text { módosított } \\
\text { poliszacharidok }\end{array}$ & $\begin{array}{c}\text { módosított amilóz és } \\
\text { cellulóz }\end{array}$ & $\begin{array}{l}\text { H-híd, } \pi \text { - } \pi \text {, dipólusos, } \\
\text { sztérikus }\end{array}$ \\
\hline & $\begin{array}{c}\text { cinkóna alkaloid alapú } \\
\text { ioncserélők }\end{array}$ & $\begin{array}{l}\text { módosított cinkóna } \\
\text { alkaloid }\end{array}$ & $\begin{array}{l}\text { ionos, H-híd, } \pi-\pi \text {, } \\
\text { sztérikus }\end{array}$ \\
\hline & fehérje alapú & természetes fehérjék & $\begin{array}{c}\text { ionos, H-híd, } \pi-\pi, \\
\text { diszperziós }\end{array}$ \\
\hline & \multirow{2}{*}{$\begin{array}{c}\text { zárványkomplex } \\
\text { képzők }\end{array}$} & ciklodextrinek & \multirow{2}{*}{$\begin{array}{l}\text { zárványkomplexképzés, } \\
\text { ionos, hidrofób, H-híd, } \pi \text { - } \\
\pi \text {, diszperziós, sztérikus }\end{array}$} \\
\hline & & ciklofruktánok & \\
\hline & $\begin{array}{l}\text { makrociklusos } \\
\text { antibiotikumok }\end{array}$ & $\begin{array}{c}\text { makrociklusos } \\
\text { glikopeptidek }\end{array}$ & $\begin{array}{l}\text { elektrosztatikus, H-híd, } \\
\pi-\pi, \text { hidrofób, sztérikus }\end{array}$ \\
\hline \multirow{6}{*}{ 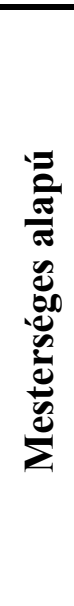 } & ligandum cserés & aminosav-fém komplex & komplexképződés \\
\hline & $\begin{array}{c}\text { zárványkomplex } \\
\text { képzők }\end{array}$ & királis koronaéter & $\begin{array}{l}\text { zárványkomplexképzés, } \\
\text { ionos, hidrofób, H-híd, } \pi \text { - } \\
\pi \text {, diszperziós, sztérikus }\end{array}$ \\
\hline & $\begin{array}{c}\text { donor-akceptor (Pirkle- } \\
\text { típusú) }\end{array}$ & $\begin{array}{l}\pi \text {-savas, } \pi \text {-bázikus } \\
\text { vegyületek }\end{array}$ & H-híd, $\pi$ - $\pi$, dipólusos \\
\hline & szintetikus polimerek & $\begin{array}{l}\text { poliakrilamid, } \\
\text { poliizocianid stb. }\end{array}$ & H-híd, $\pi-\pi$, sztérikus \\
\hline & $\begin{array}{l}\text { molekuláris lenyomatú } \\
\text { polimerek }\end{array}$ & $\begin{array}{l}\text { szelektív szorbensek (pl.: } \\
\text { szerves kopolimerek) }\end{array}$ & H-híd, $\pi$ - $\pi$, sztérikus \\
\hline & mesterséges ioncserélők & $\begin{array}{l}\text { anion- és kationcserélők, } \\
\text { ikerionos ioncserélők }\end{array}$ & $\begin{array}{l}\text { ionos, H-híd, } \pi-\pi \text {, } \\
\text { sztérikus }\end{array}$ \\
\hline
\end{tabular}

3. táblázat A gyakorlati jelentőséggel rendelkező királis állófázisok és főbb jellemzőik 
Munkám középpontjában a módosított poliszacharid alapú és a cinkóna alkaloid alapú királis állófázisok állnak, ezért a következőkben ezek jellemző tulajdonságait és alkalmazásait foglalom össze.

\subsubsection{Módosított poliszacharid alapú kolonnák}

A poliszacharid alapú királis elválasztást először 1951-ben alkalmazták királis aminosavak papírkromatográfiás elválasztására. Ezt követően a hordozó nélküli mikrokristályos cellulóz-triacetát alkalmazása került előtérbe. Ennek fő oka a poliszacharid duzzadása során kialakuló másodlagos szerkezet volt, amely enantioszelektív királis üregek kialakulását teszi lehetővé [38]. A kicsi mechanikai szilárdság és a használható oldószerek szük köre korlátozta a szelektor alkalmazhatóságát.

A széleskörü elterjedéshez szükséges áttörést Okamoto és munkatársai 1984-ben érték el, a szilikagélhez történő fenilkarbamát cellulózszármazék fizikai rögzítésével. Ennek hatására megváltozott a poliszacharid enantiomerfelismerő-képessége, javult az anyagátadás hatékonysága, a mechanikai szilárdság, valamint a hidroxilcsoportok módosításával a szelektivitás növelése is lehetővé vált. A számos poliszacharid típus közül a gyakorlatban egyedül a cellulóz és az amilóz alapú karbamát- és észterszármazékok váltak analitikai és preparatív méretben egyaránt kereskedelmi forgalomban elérhetővé [39]. Elterjedésüket elősegítette a hatékony királis felismerőképesség, a kiindulási anyag tiszta formában való hozzáférhetősége és a kémiai módosításuk egyszerüsége [40]. A poliszacharid alapú állófázisok fejlődésének következő állomása 1987-ben a szilikagélhez kémiai kötéssel való rögzítés volt, amely módszer igazán a 2000-es években vált elterjedté [40]. Így lehetővé vált korában ilyen célra nem használható oldószerek (pl.: kloroform, aceton, tetrahidrofurán, etilacetát) széleskörü használata, ami a preparatív célú elválasztás számára különösen hasznos sajátság. Az új oldószerek használata jelentősen bővítette a szelektorok alkalmazási körét, mivel a fizikai kölcsönhatásokkal rögzített szelektorok esetén a kolonnát dedikáltan alkánalkohol alapú normál fázisú (NP) eluensrendszerrel vagy poláris-szerves (PO) körülmények között (pl.: alkohol és acetonitril alkalmazása), valamint későbbi fejlesztéseknek köszönhetően fordított fázisú (RP) elválasztásra lehetett csak alkalmazni [27, 41]. Az összes királis állófázist tekintve a módosított poliszacharid alapú kolonnák a legelterjedtebbek a királis folyadékkromatográfia területén [35].

Kromatográfiás hatékonyság tekintetében összehasonlítva a fizikailag és a kémiailag kötött poliszacharid állófázisokat gyakran a kémiailag kötöttek rosszabb enantiomerfelismerő-képességgel rendelkeznek [42]. Ennek feltehetően az az oka, hogy a 
kémiai kötést lehetővé tevő csoportok kapcsolása a polimerlánchoz rögzíti annak szerkezetét. Azonban a gyengébb enantiomer elválasztóképesség jól ellensúlyozható a változatos eluensrendszerek segítségével. A fizikailag és a kémiailag kötött szelektorok eltérő királis felismerőképességét és működését jól illusztrálja, hogy azonos szerkezetü szelektor esetén az enantiomer sorrend akár meg is fordulhat [43, 44].

Az eltérő felhasználási célok miatt a két különböző módon rögzített állófázis közül egyik sem vált egyeduralkodóvá a gyakorlatban, a gyártók egyaránt forgalmazzák őket. Bár a forgalmazott poliszacharid oszlopok közül sok azonos szelektorral rendelkezik, azonban az eltérő minőségü hordozó, a különböző polimerizációs fok, valamint a szelektor változatos rögzítési módjai jelentős szelektivitásbeli különbséget okozhatnak közöttük.

A módosított poliszacharid alapú állófázisok kiemelkedő enantioszelektivitása három fő szerkezeti tulajdonság együttes hatásának következménye [27]:

- Molekuláris kiralitás: a glükopiranóz egységen található kiralitáscentrumok okozzák.

- Konformációs kiralitás: a D-glükóz molekulákból felépülő polimerlánc lineáris (cellulóz esetén), vagy helikális (amilóz esetén) térszerkezetéből adódik.

- Szupramolekuláris kiralitás: a szomszédos polimerláncok egymáshoz képest való elrendeződése.

Napjainkban a poliszacharid alapú állófázisok fő fejlesztési iránya a szilikagél hordozó szemcseméretének csökkentése, illetve a polimerlánchoz kapcsolt aromás gyürükön található szubsztituensek minőségének és helyzetének optimalizálása [35]. Az alkilcsoportokkal módosított poliszacharidok használata jelentősen visszaszorult [20]. Emellett a cikloalkil-csoportokat tartalmazó poliszacharid állófázisok az alacsony UV-fény elnyelésük és jó királis felismerőképességük miatt a vékonyrétegkromatográfiában válhatnak elterjedtté [39]. A fenilcsoporthoz kapcsolt szubsztituensek helyzetét vizsgálva jellemző, hogy az orto helyzetben szubsztituenst tartalmazó poliszacharid szelektorok kisebb királis felismerést mutatnak, mint a meta és para helyzetü szubsztituenssel rendelkezök [27].

A 4. táblázat néhány széleskörben elterjedt cellulóz és amilóz alapú poliszacharid állófázis szerkezetét mutatja be. A fenilkarbamát-csoportokon található elektronszívó (pl.: halogének) vagy elektronküldő (pl.: alkil) szubsztituensek megváltoztatják a karbamátcsoport elektronsürüségét és így hatással vannak az enantioszelektivitás mértékére. Elektronszívó csoportok esetén a karbamátcsoport nitrogénje könnyebben leadja a hozzá kapcsolódó hidrogént, ezért, ha a szelektor és az elválasztandó enantiomer között kialakuló 
kölcsönhatások közül a hidrogénhíd a meghatározó, akkor a retenciós idő növekedése várható [45]. Ezzel szemben, ha a fenilcsoport elektronküldő szubsztituenst tartalmaz, akkor a karbamátcsoporton található oxigén atom elektronsürüsége nő meg, így a szintén nagyobb elektronsűrüségü szubsztituenseket tartalmazó enantiomerekkel alakulhat ki erősebb kölcsönhatás. Az elektronszívó és elektronküldő szubsztituenst egyaránt tartalmazó fenilcsoport esetén széleskörübb királis felismerés figyelhető meg, mintha csak az egyik típusú módosító lenne jelen [46]. Emellett a fenilcsoporton található szubsztituens minősége önmagában is jelentősen befolyásolhatja a kialakuló kölcsönhatásokat és az enantioszelektivitás hatékonyságát. Például a kifejezetten poláris nitro- vagy metoxicsoport esetén csökken az enantiomerfelismerö-képesség, ezért poláris szubsztituensekkel ritkán módosítják a fenilcsoportot. A hatékonyságcsökkenés legvalószínűbb oka, hogy az erősen poláris szubsztituensek miatt kialakuló kölcsönhatások nem enantioszelektívek, mivel a glükopiranóz királis szénatomjaitól messze találhatók.

A kialakuló kölcsönhatások típusát tekintve jellemzően a hidrogénhíd, a $\pi$ - $\pi$, és a dipólusdipólus kölcsönhatások meghatározók. A hidrogénhíd és a dipólusos kölcsönhatás föként a karbamátcsoporthoz, míg a $\pi$ - $\pi$ kötések a fenilcsoporthoz rendelhetők. A $\pi$ - $\pi$ kölcsönhatások esetén az általános sav-bázis elmélet alapján Lewis savnak tekinthető az aromás rendszer, ha elektronsürüség csökkentő szubsztituens kapcsolódik hozzá, illetve elektronküldő csoport esetén, Lewis bázisként viselkedhet. A hidrogénhíd meghatározó hatása az enantiomerfelismerő-képességre jelentősen csökkenhet a mozgófázisban található víz hatására, ezért ezek az állófázisok jellemzően normál fázisú körülmények között alkalmazhatók. A szelektor és a vizsgált komponensek között fellépő kölcsönhatásokkal kapcsolatban nem szabad figyelmen kívül hagyni, hogy a kialakuló kölcsönhatások erősségének növekedése nem feltétlenül vezet az enantioszelektivitás növekedéséhez.

A királis felismerésben részt vevő kölcsönhatások szerepét többek között NMR, IR, termodinamikai sajátosságokat, molekulamodellezési és szerkezet-retenciós tulajdonság kapcsolatot vizsgáló módszerekkel kutatják [47-49]. 


\begin{tabular}{|c|c|c|c|}
\hline Polimer lánc & \multirow[t]{2}{*}{$R$ csoport } & \multirow{2}{*}{$\begin{array}{c}\begin{array}{c}\text { Szelektor } \\
\text { neve }\end{array} \\
\text { trisz-(3,5- } \\
\text { dimetilfenil- } \\
\text { karbamát) }\end{array}$} & \multirow{2}{*}{$\begin{array}{c}\begin{array}{c}\text { Kolonna } \\
\text { név }\end{array} \\
\begin{array}{c}\text { Chiralpak } \\
\text { IA }\end{array}\end{array}$} \\
\hline \multirow{6}{*}{ amilóz } & & & \\
\hline & & $\begin{array}{l}\text { trisz-(3- } \\
\text { klórfenil- } \\
\text { karbamát) }\end{array}$ & $\begin{array}{c}\text { Chiralpak } \\
\text { ID }\end{array}$ \\
\hline & & $\begin{array}{l}\text { trisz-(3,5- } \\
\text { diklórfenil- } \\
\text { karbamát) }\end{array}$ & $\begin{array}{c}\text { Chiralpak } \\
\text { IE }\end{array}$ \\
\hline & & $\begin{array}{l}\text { trisz-(3-klór- } \\
\text { 4-metilfenil- } \\
\text { karbamát) }\end{array}$ & $\begin{array}{c}\text { Chiralpak } \\
\text { IF }\end{array}$ \\
\hline & & $\begin{array}{l}\text { trisz-(3-klór- } \\
\text { 5-metilfenil- } \\
\text { karbamát) }\end{array}$ & $\begin{array}{c}\text { Chiralpak } \\
\text { IG }\end{array}$ \\
\hline & & $\begin{array}{l}\text { trisz-(S)- } \\
\text { (metilbenzil- } \\
\text { karbamát) }\end{array}$ & $\begin{array}{c}\text { Chiralpak } \\
I H\end{array}$ \\
\hline & & $\begin{array}{l}\text { trisz-(3,5- } \\
\text { dimetilfenil- } \\
\text { karbamát) }\end{array}$ & $\begin{array}{c}\text { Chiralpak } \\
\text { IB }\end{array}$ \\
\hline cellulóz & & $\begin{array}{l}\text { trisz-(3,5- } \\
\text { diklórfenil- } \\
\text { karbamát) }\end{array}$ & $\begin{array}{c}\text { Chiralpak } \\
\text { IC }\end{array}$ \\
\hline
\end{tabular}

4. táblázat Poliszacharid alapú királis állófázisok szerkezete (Daicel, Tokyo, Japán) 


\subsubsection{Cinkóna alkaloid alapú állófázisok}

A cinkóna alkaloidok csoportja hozzávetőlegesen 35 különböző heterociklusos vegyületböl áll [50], melyek bioszintézisének közös kiindulási pontja a triptofán [51]. A természetben legnagyobb mennyiségben a kínafa és a remijiafa kérgében találhatók meg, felhasználásuk alapján legjelentősebbnek a kinolin vázas vegyületek tekinthetők: kinin, kinidin, kinkonin és kinkonidin [51]. A kinin gyógyszerként való felhasználása miatt kiemelkedő fontossággal rendelkezik, Európában malária kezelésére az 1630-as évektől egészen napjainkig használják [52]. Gyógyszerészeti felhasználása mellett számos területen hasznosítják, többek között katalizátorként királis szintézisek esetén, enantioszelektív állófázisok szelektoraként, ízesítőszerként, valamint a szintén jelentős, szívritmus szabályozó gyógyszerként használt, kinidin alapanyaga. Bár a kinint 1820-ban izolálták először, a teljes szintézisére 2001-ig kellett várni, így legfőbb forrása továbbra is a kínafa kérge [53].

A cinkóna alkaloidok királis állófázisként való felhasználására már az 1950-es évektől van példa, azonban szilikagélhez kapcsolt szelektorként csak az 1980-as évektől vizsgálták őket [54]. Ezekben az években a kinin és kinidin alapú állófázisok nem terjedtek el széles körben, mivel az állófázisok kis stabilitása és az alkalmazhatóság szük köre mellé, csekély enantioszelektivitás társult. Mindez megváltozott az 1990-es években, amikor Lindner és munkatársai a kinin és kinidin szekunder C9-es szénatomján található hidroxilcsoportot először karbamoilcsoportra [55], később tercier-butil-karbamoil-csoportra cserélték [56]. Ennek hatására a gyenge anioncserélő szelektor enantiomerfelismerő-képessége jelentősen javult és széles körben elterjedtté vált. Az évek során számos cinkóna alkaloid alapú királis állófázist terveztek, azonban széleskörüen csak a kinin és kinidin alapú kolonnák terjedtek el [31]. A leggyakrabban használt cinkóna alkaloid alapú gyenge anioncserélő kolonna kereskedelmi forgalomba Chiralpak $Q N-A X$ és $Q D-A X$ néven került, szerkezetét és egy általános modellvegyülettel való kölcsönhatását a 4. ábra mutatja be. A kinin és kinidin molekulák diasztereomerei egymásnak, mivel négy királis szénatomjuk közül kettő ellentétes konfigurációjú, a kinin $8 S$, $9 R$; a kinidin $8 R$, $9 S$. Jellemzően egy ötödik kiralitáscentrum is kialakul mindkét molekulán a tercier-aminocsoport protonálódásával. Ha az enantiomer felismerés folyamata során a C8 és C9 szénatom konfigurációja meghatározó, akkor az ellentétes térbeli elrendeződés hatására a királis szelektorok úgynevezett pszeudoenantiomer viselkedést mutatnak. A pszeudoenantiomer viselkedés során az egymással disztereomer viszonyban álló $Q N-A X$ és $Q D-A X$ kolonnák szelektorai 
enantiomerpárként viselkednek, az oszlopok cseréjével az adott enantiomerek elúciós sorrendje megfordítható $[57,58]$.

A gyenge anioncserélő szelektorok alkalmazhatósági körének bővítése érdekében, a tercier-butil-karbamoil-csoport helyére karbamát kötéssel, erős kationcserélő szelektorokban alkalmazott, királis amino-ciklohexánszulfonsav-csoport került beépítésre [59]. Az így előállított új szelektorok ikerionos sajátságúak, kation- és anioncserélő funkciós csoportokat egyaránt tartalmaznak, szerkezetüket a 4. ábra mutatja be. Mivel a királis amino-ciklohexánszulfonsav-csoportok $S, S$ - vagy $R, R$-konfigurációval rendelkeznek, így a szintén királis kinin és kinidin alapmolekulákhoz kapcsolva őket, 4 féle konfigurációjú ikerionos szelektor hozható létre.

A cinkóna alkaloid alapú királis állófázisok összetett szerkezetük révén számos kölcsönhatást kialakíthatnak az elválasztandó komponensekkel. A heterociklusos aromás kinolin $\pi$ - $\pi$ kötést alakíthat ki, valamint méretéböl fakadóan sztérikus taszítással bír. A szintén terjedelmes kinuklidin gyürürendszerben található nitrogén protonálódása révén $\left(\mathrm{pK}_{\mathrm{s} \text { (aq.) }} \approx 9,8\right)$ elektrosztatikus kölcsönhatást alakíthat ki [37]. Emellett az ikerionos szerkezetü ZWIX kolonnák szelektorain a szulfonsavcsoport $\left(\mathrm{pK}_{\mathrm{s}(\mathrm{aq} .)} \approx 1\right)$ szintén kialakíthat erős elektrosztatikus kölcsönhatást. A szelektorokon található karbamát kötés H-híd kialakításával jelentősen segítheti a szelektor enantiomerfelismerő-képességét. Az enantiomer felismerés folyamata során nem elhanyagolhatók a gyengébb dipólusos és van der Waals kölcsönhatások sem [31, 55, 60].

Ioncserélő állófázisként jellemzően a szelektor és az elválasztandó komponensek töltéssel rendelkező funkciós csoportjai között kialakuló elektrosztatikus kölcsönhatások határozzák meg a vizsgált vegyületek visszatartását. Ezért a retenciót kialakító ionizálható funkciós csoportok megfelelő protonáltsági állapotához a mozgófázis sav, illetve bázis módosítókat kell tartalmazzon. Mivel az elválasztás során az ioncserélő szelektor kötőhelyeiért versengenek a mozgófázisban található elválasztandó komponensek és a mozgófázisban található egyéb ionok, ezért a hozzáadott sav és bázis módosítók mennyiségével a vizsgált komponensek visszatartása hangolható. Ikerionos szelektorok esetén a kationcserélő szulfonsavcsoport, illetve az anioncserélő protonált tercier-amin-csoport, elég messze vannak egymástól, hogy külön-külön kölcsönhatásba lépjenek a nekik megfelelő ionos állapotú molekulával, így monoionos szelektorként is használhatók [61]. Az ikerionos szelektor ionizálható funkciós csoportjai egyidejűleg is ionizálódhatnak, ez esetben amfolit komponensekkel kettős ionpár kölcsönhatás alakulhat ki [59, 62, 63]. Mivel az ikerionos szelektor egyaránt tartalmaz pozitív és negatív töltésü funkciós csoportot, ezért a szelektor 
és az elválasztandó komponens között kialakuló vonzó elektrosztatikus kölcsönhatás mellett, egyidejűleg megjelenhet taszító kölcsönhatás is, a szelektor és a vizsgált molekula azonos töltésü funkciós csoportjai következtében [64].
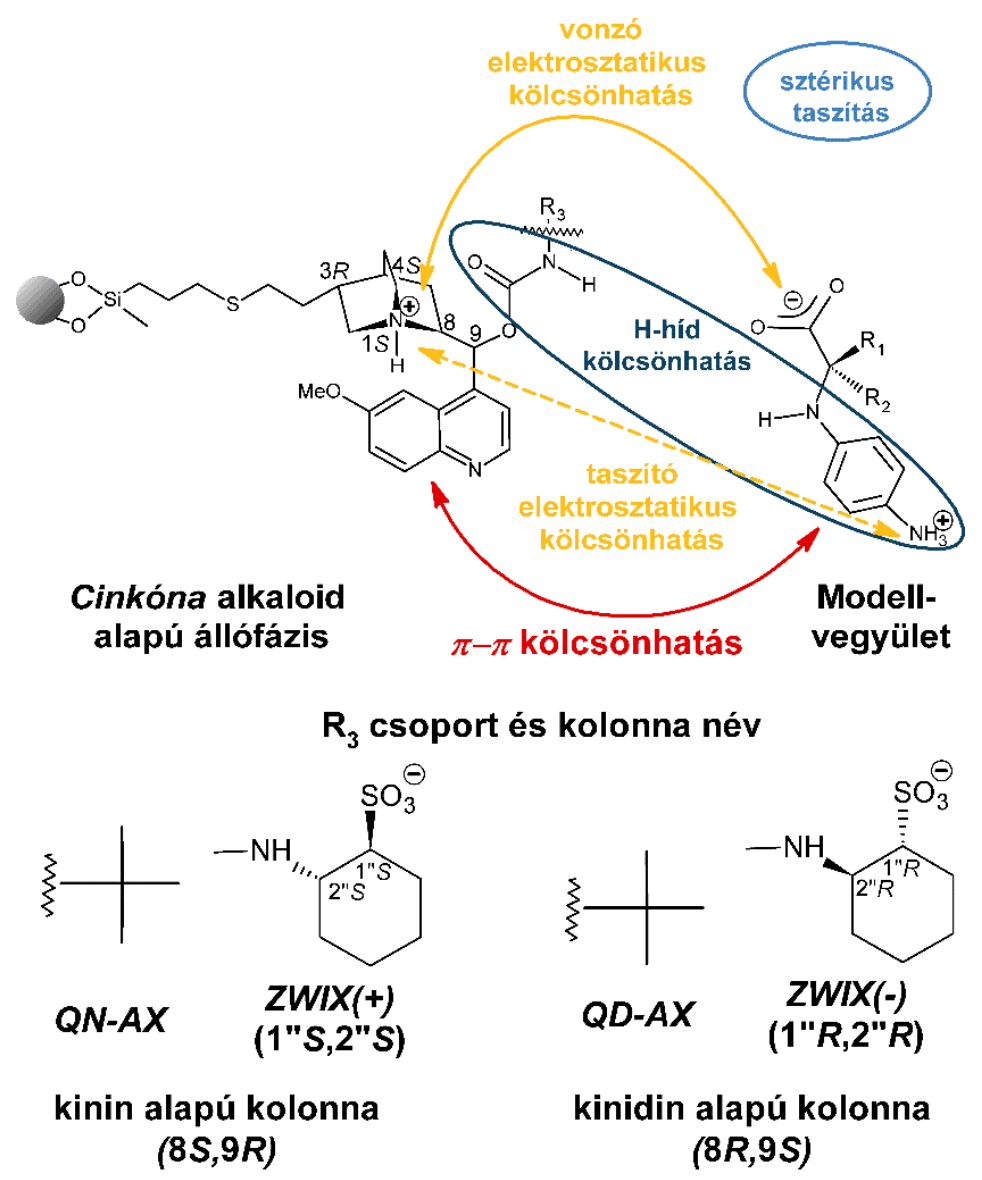

4. ábra A legjelentősebb cinkóna alkaloid alapú királis állófázisok szerkezete és néhány lehetséges kölcsönhatása egy ikerionos szerkezetủ modellvegyülettel

\subsection{Az SFC technika alkalmazása királis vegyületek elválasztására}

\subsubsection{Az SFC technika fontosabb jellemzői}

Az SFC technika, angolul Supercritical Fluid Chromatography, jelenleg nem rendelkezik általánosan elfogadott magyar névvel, ezért dolgozatomban az angol rövidítéssel jelölöm. A pontos elnevezés hiányának egyik fö oka, hogy az eluensként cseppfolyós gázt és folyékony módosítókat együtt használó kromatográfiás rendszert leíró fizikai sajátságok és az eluens halmazállapota kizárólag kromatográfiás módszerekkel nem ismerhetők meg. Továbbá e technika angol elnevezése, bár nevével nem fejezi ki, azonban magába foglalja a szubkritikus állapotú eluenst alkalmazó kromatográfiás rendszereket is [65]. Napjaink SFC müszerei nem minden esetben teszik lehetővé a gyakorló kromatográfus számára, hogy megállapítsa, vajon az alkalmazott mérési körülmények során szub- vagy 
szuperkritikus állapotú a használt eluensrendszer [66]. Emellett, összetett eluensrendszer esetén, a két állapot közötti átmenet nem definiálható éles határvonallal [67, 68]. Ezért a szub- és szuperkritikus folyadék (vagy fluidum) kromatográfia a gyakorlatban nem osztható fel további részekre az alkalmazott mozgófázis halmazállapota alapján.

A kritikus pont közelében az anyagok egyedi, a folyékony vagy gáz halmazállapotuktól eltérő fizikai tulajdonságokkal rendelkeznek, ami felhasználásuk új lehetőségeit teremti meg $[69,70]$. A kritikus pontot meghaladó nyomás vagy hőmérséklet esetén szuperkritikus halmazállapot figyelhető meg, amikor a rendszer fizikai és kémiai tulajdonságai a gáz és folyadék halmazállapot közé esnek. A szuperkritikus fluidumra jellemző, hogy kitölti a rendelkezésére álló teret, felületi feszültséggel nem rendelkezik, viszkozitása és diffúziója a gázokhoz, sűrüsége és oldóképessége inkább a folyadékokhoz hasonló. A kisebb viszkozitás következtében kisebb a kolonnán létrejövő nyomásesés, ezért hosszabb kolonna vagy nagyobb áramlási sebesség használható a HPLC technikához képest. A folyadékhoz képest nagyobb diffúziós együttható kedvezően hat a mozgófázis anyagátadási képességére, így hatékonyabb elválasztás érhető el. Azonban fontos megjegyezni, hogy a kritikus pont közelében, a mozgófázis fizikai-kémiai tulajdonságai nagymértékben függenek a rendszer hőmérsékletétől és nyomásától [71]. Ez felveti a lehetőséget, hogy a hőmérséklet vagy a nyomás változtatásával a kromatográfiás rendszer fizikai-kémiai tulajdonságai „hangolhatók” [70, 72]. Ezzel szemben, egy adott kromatográfiás rendszer vizsgálata során, ezen állapothatározók állandó értéken való tartása nélkülözhetetlen, a mozgófázis változatlan fizikai-kémiai jellemzőinek biztosításához.

Az ideális SFC mozgófázis keresése során számos vegyület szuperkritikus állapotát megvizsgálták, azonban előnyös tulajdonságai következtében a folyékony szén-dioxid terjedt el a legszélesebb körben. A folyékony szén-dioxidot kedvező SFC mozgófázis alkotóként használni, mivel [73]:

- alacsony a kritikus nyomása és hőmérséklete (73 bar és $31{ }^{\circ} \mathrm{C}$ ), így kevesebb energia szükséges a kritikus állapot fenntartásához,

- kémiailag inert, nem gyúlékony, korlátozottan mérgező és nem szennyezi a környezetet (,zöld kémia”),

- megfelelő tisztasággal költséghatékonyan beszerezhető,

- nagy mennyiségü felhasználás esetén újrahasznosítható, pl.: preparatív elválasztások,

- a legtöbb szerves oldószerrel jól elegyedik és UV-elnyelése alacsony hullámhosszak esetén sem jelentős. 
Az SFC technika már az 1960-as években létezett, azonban a HPLC-hez képest jelentősen lassabban fejlődött egészen az 1980-as és 90-es évekig [74]. Az SFC fejlesztések újabb fellendülését nagy mértékben segítette a királis elválasztás területe, ahol rövidebb mérési idő mellett a HPLC technikát meghaladó elválasztásokat sikerült elérni $[69,73,75]$. Napjaink modern SFC müszerei felépítésükben számos pontban különböznek a HPLC készülékektől. A holttérfogatokat tekintve az SFC rendszerek közelebb állnak az ultranagy-hatékonyságú folyadékkromatográfiás (UHPLC) müszerekhez, mint a HPLC készülékekhez. További eltérés a két müszertípus között, hogy az SFC esetén, mivel az eluens folyékony széndioxidot is tartalmaz, ezért folyamatosan precízen szabályozott ellennyomást kell fenntartani a rendszerben, nehogy a kolonnában vagy a detektorban gáz fejlődhessen. A pontosan szabályozott nyomás mellett a rendszer hőmérséklete is a HPLC berendezéseknél megszokott mértéknél jobban szabályozott, így biztosítva az eluens állandó fizikai tulajdonságait és az analitikai meghatározásokhoz szükséges ismételhetőséget [76].

\subsubsection{Az SFC technika alkalmazása királis komponensek elválasztására}

A királis vegyületek SFC technikával történő elválasztásának több mint 30 évre nyúló hagyománya van [77], azonban a kromatográfiás rendszerben lezajló folyamatok pontos feltérképezése még napjainkban sem ért véget [65]. Az SFC rendszerek összetettsége következtében, lásd 5. ábra, a mérési körülmények optimalizálása mellett, a sikeres elválasztáshoz nélkülözhetetlen a megfelelő mozgófázis összetétel és királis kolonna kiválasztása.

Az SFC technika mozgófázisa jellemzően 1 - 50\%-ban tartalmaz szerves oldószereket vagy 1 -10\%-ban vizet a szén-dioxid mellett, így az eluens polaritása és oldóképessége, a kialakuló kölcsönhatások és az elválasztás hatékonysága jól szabályozható. A leggyakrabban metanol $(\mathrm{MeOH})$, etanol $(\mathrm{EtOH})$ vagy 2-propanol (2-PrOH) használatos eluens módosítóként $[66,78]$. A szerves oldószerek használata összetett változásokat okoz a kromatográfiás rendszerben, megváltoztathatja az állófázis polaritását, konformációját, valamint a felületén feldúsulva a mozgófázistól jelentősen eltérő környezetet alakíthat ki [79]. A mérési körülményektől függően, ha az eluens csak 2,0\% $\mathrm{MeOH}-\mathrm{t}$ tartalmaz, az állófázis felületén kialakuló oldószer rétegben képes akár 25\%-os mennyiségre is feldúsulni [80]. A szerves módosítók mellett a mozgófázis kis mennyiségben (jellemzően 0,1 - 0,5\%ban) gyakran tartalmaz savas vagy bázikus komponenseket [81]. Kis mennyiségü sav vagy bázis hatására gyakran tapasztalható, hogy a csúcsalak, illetve a detektálás javul, valamint a szelektivitás növekszik [66]. Emellett a szén-dioxid és az eluensben található alkohol egy 
része nyomás alatt in situ alkoxikarbonsav képződéséhez vezet, mely szintén hatással van az eluens polaritására $[82,83]$.

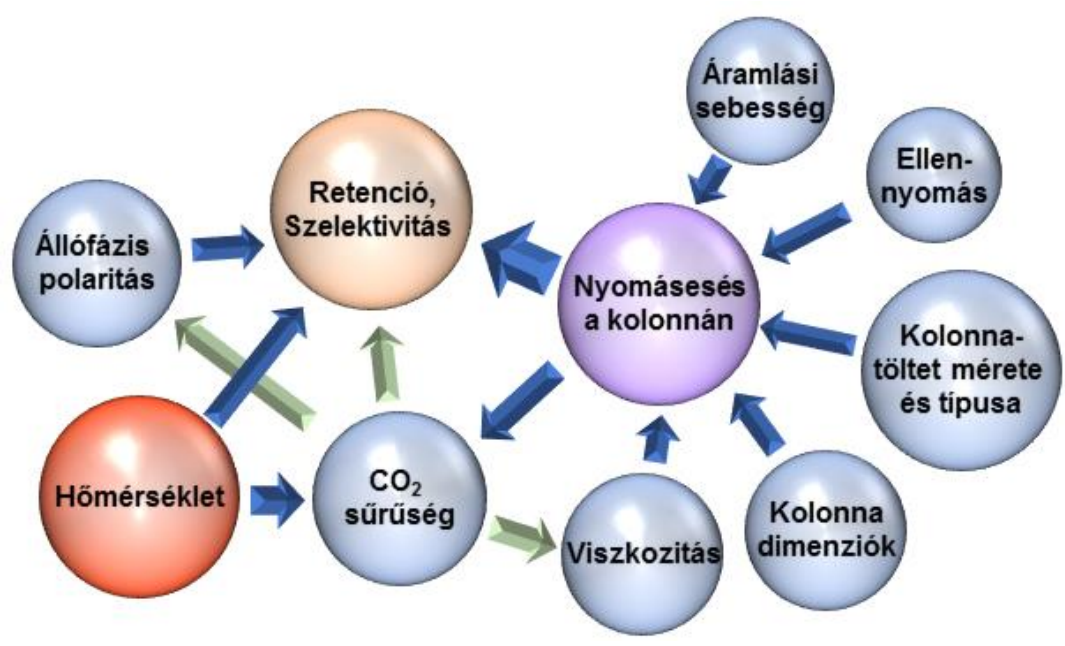

5. ábra A kromatográfiás rendszer müködését befolyásoló néhány mérési körülmény egymásra gyakorolt hatásai SFC technika esetén. Zöld nyíl jelöli a szén-dioxidhoz adott módosítók hatását

Ezek alapján, a kromatográfiás rendszerben kialakuló összetett kölcsönhatások miatt az eluenshez adott módosítók és szerves oldószerek elválasztásra kifejtett hatása jelenleg csak kísérleti úton határozható meg. Ezzel összefüggően, a mozgófázis összetételének optimalizálása csak a megfelelő királis állófázis használatával vezethet sikeres elválasztáshoz.

Napjainkban, az SFC technikával történő elválasztáshoz, több mint 200 királis kolonna kapható kereskedelmi forgalomban [66]. Ezek szinte kivétel nélkül töltetes kolonnák, melyek többsége folyadékkromatográfiában is használható. A föbb királis állófázis típusok közül egyedül a fehérje alapúak nem használhatók SFC technikával. Az SFC módszerrel történő enantiomer elválasztáshoz, a HPLC technikához hasonlóan, leggyakrabban módosított poliszacharid alapú kolonnát használnak [65]. A fizikailag és a kémiailag kötött poliszacharid állófázisok jellemzően nem mutatnak jelentős szelektivitásbeli különbséget SFC technika esetén, azonban a kémiailag kötött szelektorokat a szélesebb oldószer kompatibilitásuk miatt előnyben részesítik.

Királis HPLC technika alkalmazásánál, számos esetben megfigyelhető, hogy a királis komponensek szerkezetének csekély különbsége a szelektivitás és a felbontás jelentős eltérését okozza. Mivel az SFC technika müködése kevésbé felderített a királis elválasztások esetén, ezért a királis felismerés és az elválasztási mechanizmusok hátterében álló folyamatok megértéséhez számos további vizsgálat szükséges. 


\subsection{A királis kromatográfia termodinamikai háttere}

A királis kromatográfiás folyamatokra gyakran jelentősebb hatást gyakorol a kromatográfiás rendszer hőmérséklete, mint a hagyományos folyadékkromatográfiára, ezért az optikai izomerek hatékony elválasztásához fontos az elválasztás folyamatát jellemző termodinamikai tulajdonságok vizsgálata.

\subsubsection{A van't Hoff egyenlet szerepe a királis kromatográfiában}

A két enantiomer csúcs egymáshoz viszonyított helyzetét a szelektivitás írja le,

$$
\alpha=\frac{k_{2}}{k_{1}}
$$

ahol $k_{1}$ és $k_{2}$ az elsőként és másodikként eluálódó komponens retenciós tényezőjét jelöli. Az elválasztás során alkalmazott hömérséklet növelése gyakran csökkenti a szelektivitást, mivel a komponensek megoszlása az álló és mozgófázis között változó mértékü hőmérsékletfüggéssel rendelkezik. Ez az ún. termodinamikai hatás, amely ionos komponenseket tartalmazó rendszerek esetén kiegészül a disszociációs állandók hőmérsékletfüggésével is. A hőmérséklet növelésének hatására azonban az eluens viszkozitása is csökken, valamint megnő az oldott anyag diffúziós állandója. E kinetikai hatások segíthetik az elválasztást, mivel megkönnyítik a mozgó- és állófázis közötti anyagátadási folyamatokat. Az egymással ellentétes hatású folyamatok eredményeként a hőmérséklet elválasztásra gyakorolt eredő hatását minden esetben kísérleti úton kell meghatározni.

Az optikai izomerek és az állófázis szelektora közötti kölcsönhatás erőssége, az 1. és 2. egyenlet alapján, arányos az átmeneti diasztereomer komplex képződését jellemző $K_{S}$ és $K_{R}$ egyensúlyi állandóval. A diasztereomer komplex egyensúlyi állandója ( $R$ - vagy $S$ enantiomer esetén általánosan $K_{\mathrm{i}}$ ) és az egyensúlyi folyamatot jellemző standard szabadentalpia változás közötti kapcsolat a 4. egyenlettel írható le,

$$
-\Delta G^{\circ}=R T \ln K_{i}
$$

ahol $\Delta G^{\circ}$ a standard szabadentalpia-változás és $R$ az egyetemes gázállandó és $T$ az abszolút hőmérséklet Kelvin-fokban megadva. Tehát, minél stabilabb a szelektor és az enantiomer által létrehozott komplex, annál több energia szabadul fel a rendszerben. Az egyensúlyi folyamat standard szabadentalpia-változása a Gibbs-Helmholtz összefüggés alapján a rendszer standard entalpia $\left(\Delta H_{i}{ }^{\circ}\right)$ és entrópia $\left(\Delta S_{i}^{\circ}\right)$ változásának együttes hozzájárulásából tevődik össze:

$$
\Delta G_{i}^{\circ}=\Delta H_{i}^{\circ}-T \Delta S_{i}^{\circ} .
$$

A 3. és 4. egyenlet felhasználásával kifejezhető az egyensúlyi állandó, 


$$
\ln K_{i}=-\frac{1}{T} \frac{\Delta H^{\circ}}{R}+\frac{\Delta S^{\circ}}{R}
$$

ami közvetlen összefüggésbe hozható a retenciós tényezővel az alábbi egyenlet alapján,

$$
\ln k_{i}=K_{i} \varphi=K_{i} \frac{V_{s}}{V_{m}}
$$

ahol $\varphi$ a fázisarány, $V_{s}$ az állófázis térfogata, $V_{m}$ a mozgófázis térfogata a kolonnában. $\mathrm{Az}$ értekezésben a fázisarányt a IUPAC ajánlástól eltérően, annak reciprokaként használom. Így a 6. és 7. egyenlet egyesítésével megkapjuk a kromatográfiában használt van’t Hoff egyenletet:

$$
\ln k_{i}=-\frac{1}{T} \frac{\Delta H^{\circ}}{R}+\frac{\Delta S^{\circ}}{R}+\ln \varphi
$$

A 8. egyenlet leírja a vizsgált komponens közvetlenül mérhető retenciós tényezője és a termodinamikai jellemzők egymástól való függését. A van’t Hoff egyenlet szerint, ha ln $k_{i}$ vs. 1/T függvényt ábrázoljuk és a mért adatokra megfelelö jósággal egyenes illeszthető, akkor az egyenes meredeksége $-\Delta H^{\circ} / R$, tengelymetszete $\Delta S^{\circ} / R+\ln \varphi$ értékét adja meg. Azonban $\Delta S^{\circ}$ értéke csak akkor használható, ha fázisarány ismert, ez viszont csak nagyon ritkán határozható meg [84]. Ezért a $\Delta H^{\circ}$ és a $\Delta S^{\circ}$ értékek helyett, termodinamikai jellemzésre, a két enantiomerre vonatkozó $\Delta\left(\Delta H^{\circ}\right)$ és a $\Delta\left(\Delta S^{\circ}\right)$ különbségeket használjuk, amint azt a következőkben tárgyalom.

Két optikai izomer standard szabadentalpia-változásának különbsége a kromatográfiás elválasztás mechanizmusába enged betekintést. Ha az elsőként és másodikként eluálódó komponens standard szabadentalpia-változását 1-es és 2-es jelöli, akkor az enantiomerek standard szabadentalpia-változás különbsége:

$$
\Delta\left(\Delta G^{\circ}\right)=\Delta G_{2}^{\circ}-\Delta G_{1}^{\circ}=-\mathrm{RT} \ln \frac{k_{2}}{k_{1}} .
$$

Így a 3., 5. és 9. egyenlet egyesítésével kifejezhető a van’t Hoff egyenlet fázisarányt nem tartalmazó formája:

$$
\ln \alpha=-\frac{1}{T} \frac{\Delta\left(\Delta H^{\circ}\right)}{R}+\frac{\Delta\left(\Delta S^{\circ}\right)}{R} .
$$

Mivel az állófázisok tényleges térfogata nem ismert és a fázisarány pontos értékét, mely a körülményektől függően akár változhat is [85], csak független mérésekkel lehet meghatározni, az elhanyagolásoktól mentes, valós entalpia és entrópia értékek meghatározására a van’t Hoff egyenlet önmagában nem alkalmas. Azonban megfelelő egyszerüsítések figyelembevételével a van’t Hoff egyenlet használatával kapott 
termodinamikai adatokból hasznos elméleti és gyakorlati következtetések tehetők az elválasztás mechanizmusának részletesebb megértéséhez [86].

\subsubsection{A királis kromatográfia termodinamikai sajátságai}

Királis kromatográfiás rendszerek esetén fontos figyelembe venni, hogy az állófázis királis szelektora egyaránt tartalmaz enantioszelektív és nem szelektív kötőhelyeket és kölcsönhatásokat is. Ezért az adott rendszer esetén mért szelektivitás mindig kisebb, mint a tisztán enantioszelektív kölcsönhatások esetén lehetséges lenne. Az enantioszelektív és nem szelektív kölcsönhatások megkülönböztetése jelenleg ritkán célja a kromatográfiás folyamatok vizsgálatának. Mivel az állófázis tulajdonságai (pl.: fizikai tulajdonságok, borítottság, szelektor rögzítése, szelektor anyagi minősége stb.) és a mozgófázis összetétele egyaránt meghatározó az adott elválasztásban szerepet játszó kötőhelyek számát és eloszlását tekintve, ezért a kétféle típusú kölcsönhatás megkülönböztetése jelentős kihívásokkal rendelkezik [84, 87]. Az enantioszelektív és nem szelektív kölcsönhatások megkülönböztetésére leggyakoribb módszer az adszorpciós izotermák meghatározása [88, 89] és az inverz kromatográfiás módszer [90].

A kromatográfiás rendszerek esetén az adszorpció az oldott komponensek átmenetét jelenti a mozgófázis és az állófázis között. Folyadékkromatográfia esetén az adszorpciós folyamat magába foglalja az oldott anyag, illetve az állófázis oldószerburkától való deszolvatációját, az átmeneti komplex kialakulását az állófázis felületén, az átmeneti komplex szolvatációját és a mozgófázis hígulását a deszolvatáció révén tömbfázisba kerülő molekulák miatt [84]. Ezek alapján a termodinamikai állapotjelzők változása $\Delta X(X=H, S$, $G)$ a fenti folyamatok eredőjeként adhatók meg:

$$
\Delta X=\Delta X_{\text {o. a. deszolv. }+} \Delta X_{\text {álllóf. deszolv. }}+\Delta X_{\text {átm. komp. képz. }}+\Delta X_{\text {átm. komp. szolv. }}+\Delta X_{\text {hígul. }}
$$

A 11. egyenlet megmutatja, hogy a királis felismerés és az elválasztás folyamata jelentősen függ az elválasztási körülményektől, valamint, hogy az elválasztást befolyásoló nem minden folyamat mérhető csak kromatográfiás módszerekkel. Például nem szabad figyelmen kívül hagyni, hogy az állófázis szerkezete, konformációja is változhat eltérő mozgófázisok alkalmazása esetén [91].

A termodinamikai állapotjelzők összetettsége ellenére az elválasztáshoz nélkülözhetetlen átmeneti komplexek jellemezhetők az elválasztást kísérő entalpia és entrópia változás értékével. A spontán lejátszódó folyamatok termodinamikai feltétele a szabadentalpia csökkenés, mely a 10 . egyenlet alapján vagy az entalpiatag $\Delta\left(\Delta H^{\circ}\right)$ csökkenésével, vagy az entrópiatag $\Delta\left(\Delta S^{\circ}\right)$ növekedésével valósulhat meg. A mozgófázisból kilépő komponens 
állófázis felületén való megkötődése jellemzően exoterm folyamat, így a hőmérséklet növelésével a visszatartás és a szelektivitás is csökken. Az elválasztás során minél hatékonyabban tud a mozgófázisból az állófázisra jutni a vizsgált komponens és/vagy minél erősebb kölcsönhatásokat alakít ki a másodikként eluálódó enantiomer, abszolútértékben annál nagyobb érték társul az entalpiaváltozáshoz [92]. Ezzel szemben az átmeneti komplex kialakulását kísérő rendezettség változás és a megkötött enantiomer szabadsági fokának csökkenése az entrópiatag változását okozza. Feltételezve, hogy az enantiomerek elválasztása alapvetően azonos felismerési mechanizmussal megy végbe, az entalpia és entrópiatag arányával jellemezhető az elválasztás:

$$
Q=\frac{\Delta\left(\Delta H^{\circ}\right)}{\operatorname{T\times } \Delta\left(\Delta S^{\circ}\right)}
$$

A 12. egyenletben feltüntetett $\mathrm{T}$ egy adott referencia hömérsékletre vonatkozik, ha nincs feltüntetve egyéb érték, akkor 298 Kelvin. Ha $Q$ értéke nagyobb 1-nél, vagyis $\left|\Delta\left(\Delta H^{\circ}\right)\right|>\left|\mathrm{T} \times \Delta\left(\Delta S^{\circ}\right)\right|$, akkor entalpiavezérelt az elválasztás, ha kisebb egynél, tehát $\left|\Delta\left(\Delta H^{\circ}\right)\right|<\left|\mathrm{T} \times \Delta\left(\Delta S^{\circ}\right)\right|$, akkor entrópiavezérelt a folyamat. Entrópiavezérelt elválasztás figyelhető meg, ha a hőmérséklet növelésének hatására a szelektivitás növekszik [93].

A hőmérséklet változtatás hatására a visszatartás és a szelektivitás számos irányt követhet, ioncserélő állófázisok esetén a hőmérséklet növelés hatására négy jellegzetes viselkedés figyelhető meg [31]:

- I. Típus: a visszatartás és a szelektivitás is csökken (leggyakrabban megfigyelhető)

- II. Típus: a visszatartás csökken és a szelektivitás növekszik,

- III. Típus: a visszatartás növekszik és a szelektivitás csökken,

- IV. Típus: a visszatartás és a szelektivitás is növekszik.

Érdemes megemlíteni, hogy az SFC rendszerek termodinamikai vizsgálata a folyadékkromatográfiához képest további kihívásokat támaszt, mivel az adszorpciós folyamatok rendelkezhetnek nyomásfüggéssel is, valamint a van’t Hoff ábrázolás nem lineáris adatsorokat eredményez a kritikus hőmérséklet közelében [94].

\subsection{A vizsgált vegyületek kémiai és biológiai jelentősége}

\subsubsection{Indol és $\beta$-karbolin alkaloidok}

$\mathrm{Az}$ indol pontos szerkezetét először Adolf von Baeyer Nobel-díjas kémikus javasolta 1869-ben az indigóból való izolálást követően. Az izolálása óta eltelt 150 évben több mint 80000 közleményben vizsgálták az indol vegyületek kémiáját, így jelentősége és széleskörü felhasználása miatt az „aromás gyürük ura” címmel is illethető [95]. Az indolvázas 
vegyületek számos kutatási területei közül napjainkban a gyógyszeripari, az illatanyag és agrokémiai felhasználás a leggyakoribb. Indolszármazék nagyszámú gyógyszerhatóanyagban megtalálható, így alkalmazzák gyulladáscsökkentőként, rákellenes szerekben, maláriaellen, tuberkulózis kezelésére, valamint a világon közel 50 millió embert érintő epilepszia kezelésére antiepilektikumként [96].

Az indolvázas alkaloidok közé tartozik a triciklusos pirido[3,4-b]indol gyürüt tartalmazó $\beta$-karbolin és származékai. Széles körben elöfordulnak növények és gombák szöveteiben, illetve állati szövetek esetében is megtalálhatóak, valamint a triptamin vagy triptofán enzimatikus úton lejátszódó átalakulása következtében néhány képviselőjük akár endogén formában is fellelhető az emberi szervezetben [97]. Endogén származásuk ellenére a szervezetben mérhető mennyiségük nem állandó, kóros folyamatok, mint a neurológiai betegségek [98], valamint dohányzás [99] hatására mennyiségük emelkedhet és az élettani folyamatoktól eltérő változásokat indíthatnak el a szervezetben. A $\beta$-karbolin vegyületek biológiai hatásai igen sokrétüek lehetnek: tumorellenes, antivirális, malária és parazitaellenes szerekben is megtalálhatóak [100]. A központi idegrendszer eltérö receptoraihoz való kötődés következtében változatos hatást fejthetnek ki, így például nyugtató hatással is rendelkezhetnek [101]. Továbbá a harmán és norharmán vegyületek esetén megfigyelték, hogy kis méretük és merev, síkalkatú szerkezetük révén akár a DNS molekula polinukleotid láncaiba is beékelődhetnek, ami a hidrogénhíd megszünése esetén a kettős spirál kitekeredéséhez vezethet az adott szakaszon [102].

\subsubsection{Tetrahidroizokinolin- és 1-naftol-származékok}

A növényekben széles körben előforduló egyszerü izokinolin alkaloidok legnépesebb családját több mint 50 vegyülettel az 1,2,3,4-tetrahidroizokinolin-vázas molekulák alkotják [103]. E vegyületek kiemelkedő biológiai jelentőségét mutatja, hogy daganatellenes hatású antibiotikumként 1974 óta vizsgálják őket, valamint számos terápiás hatással rendelkező gyógyszermolekulának alapvető építő elemei [104]. Előnyös hatásuk ellenére e vegyületcsoportot kezdetben az idegrendszert károsító hatásukról ismerték [105]. Később azonban például az 1-metil-1,2,3,4-tetrahidroizokinolinról bebizonyosodott, hogy endogén úton termelődve Parkinson-kór megelőző hatást fejt ki emlősökben [106].

A tetrahidroizokinolin váz kombinálása kedvező biológiai hatású vegyületekkel új, az eredeti vegyületek hatását egyesítő vagy akár attól eltérő terápiás lehetőségeket teremthet [107]. Az 1-naftol származékok előnyös biológiai sajátságai közé tartozik többek között a mikróbaellenes, gombaölő [108], valamint antioxidáns [109] hatás. Így a 
tetrahidroizokinolin-származékokhoz való kapcsolása változatos szerkezetủ és hatású királis farmakonok létrehozását teszi lehetővé.

\subsubsection{Dipeptidek}

A peptidek a gyógyszervegyületek egyedi csoportját képezik, mivel méretük alapján a kis molekulák és a fehérjék között helyezkednek el, de biokémiai és gyógyászati szempontból mindkettőtől különböznek. A természetben előforduló peptidek száma 7000-et is meghaladja, és közülük számos nélkülözhetetlen az emberi szervezet egészséges működéséhez [110]. A peptidek változatos és kiemelkedő fontosságú biológiai szerepét mutatja többek között ideg ingerület átvivő [111], növekedési faktor [112], ion csatorna kialakító [113], mikróbaellenes [114], valamint hormon (pl.: inzulin) [115] funkciójuk is. A peptidek sztereokémiája meghatározza kémiai és biológiai aktivitásukat, így e királis vegyületek konfigurációjának megváltozása jelentősen eltérő hatást fejthet ki környezetükre. Ez a sajátság már a legegyszerübb szerkezetű peptideknél, a két aminosav kapcsolódásából létrejövő dipeptideknél is egyértelmüen megfigyelhető. Például a dipeptidek gyakran keserü ízzel bírnak [116], azonban az L-aszparaginsav-L-fenilalanin-metilészter, más néven az aszpartám, a szacharóznál 180-szor édesebb ízzel rendelkezik. Emellett fontos figyelembe venni, hogy a dipeptidek tulajdonságai jelentősen eltérhetnek a kiindulási aminosavakétól. Ezt igazolja például a glutamin és alanin, melyek oldhatósága vízben $36 \mathrm{~g} / \mathrm{L}$ és $167 \mathrm{~g} / \mathrm{L}$, míg az alanil-glutamin oldhatósága 568 g/L [117]. A dipeptidek terápiás célra való hasznosítása, megfelelő enantiomer tisztaság biztosítása esetén, számos új gyógyszervegyület létrejöttéhez vezethet $[118,119]$.

\section{KÍSÉRLETI RÉSZ}

\subsection{Vizsgált anyagok}

A vizsgált vegyületek biológiai jelentőséggel rendelkező anyagok, melyek együttmüködő partnereink laboratóriumaiban készültek. Előállításukra a dolgozatban nem térek ki a leírások terjedelme miatt, a leírások rövidített változata eredeti közleményeinkben megtalálható. A vizsgált vegyületeket a könnyebb átláthatóság érdekében szerkezetük szerint három csoportra osztottam és a királis szén atomokat csillaggal vagy konfigurációjuk megadásával jelöltem. 


\section{Biológiailag aktív dipeptidek}

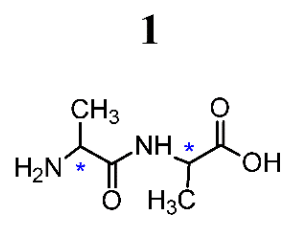

LL, DD, LD, DL alanil-alanin<smiles>CC(=N)C(=O)N[C@@H](C(=O)O)c1ccccc1</smiles>

LL, DD<smiles>CC(=N)C(=O)N[C](CC(=O)O)c1ccccc1</smiles>

LL, DD alanil-fenilglicin alanil- $\beta$-fenilalanin<smiles>CC(=N)C(=O)N[C@H](Cc1ccccc1)C(=O)O</smiles>

LL, DD, LD, DL alanil-fenilalanin

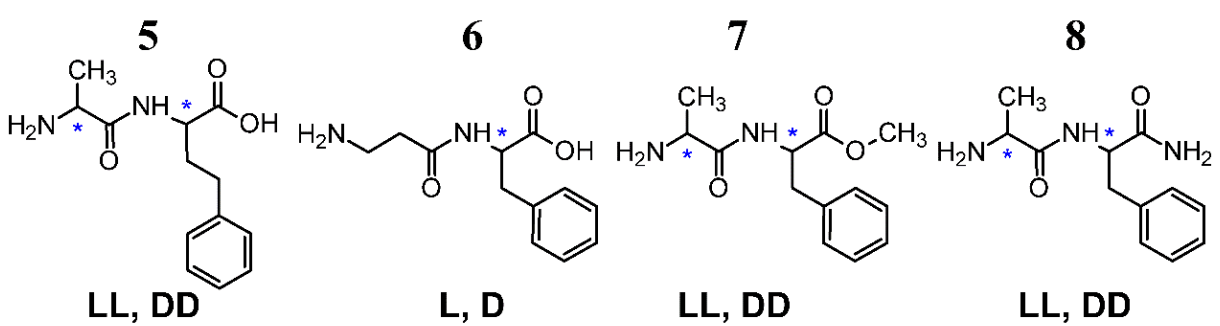
alanil-homofenilalanin $\quad \beta$-alanil-fenilalanin alanil-fenilalaninmetilészter

alanil-fenilalanin-amid

9

10

11

12

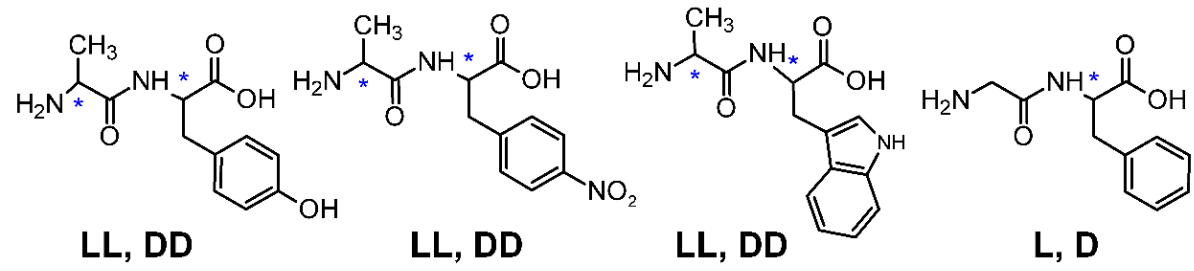

LL, DD

alanil-tirozin alanil-4-nitrofenilalanin

alanil-triptofắn

glicil-fenilalanin

13

14

15 16<smiles>N[C](Cc1ccccc1)C(=O)NCC(=O)O</smiles><smiles>CC(NC(=O)[C@H](N)Cc1ccccc1)C(=O)O</smiles><smiles>NCCCC/C(N)=C(\N)N[C@@H](Cc1ccccc1)C(=O)O</smiles><smiles>CC(C)CC(N)=C(N)C(=O)N[C@@H](CC(C)C)C(=O)O</smiles>

L, D<smiles>[14CH3][18OH]</smiles>

LL, DD

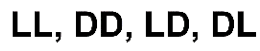

fenilalanil-glicin fenilalanil-alanin

lizil-fenilalanin
6. ábra A vizsgált dipeptid vegyületek szerkezete

\section{Bázikus és amfolit indol analógok}

17<smiles>c1ccc2c(c1)CCN[C+]2c1c[nH]c2ccccc12</smiles>

$3-(1,2,3,4-$ tetrahidroizokinolin1-il)-indol
18<smiles>O=C(O)c1[nH]c2ccccc2c1C1=NCCc2ccccc21</smiles>

$3-(1,2,3,4-$ tetrahidroindol-2-karbonsav
19

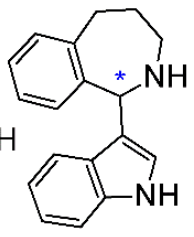

$3-(2,3,4,5-$ tetrahidro- $1 \mathrm{H}-$ 1-il)-indol indol-2-karbonsav
20

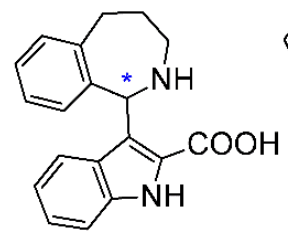

3- $(2,3,4,5-$

tetrahidro-1H-

benz $[\mathrm{c}]$ azepin-1-il)
indol-2-karbonsav

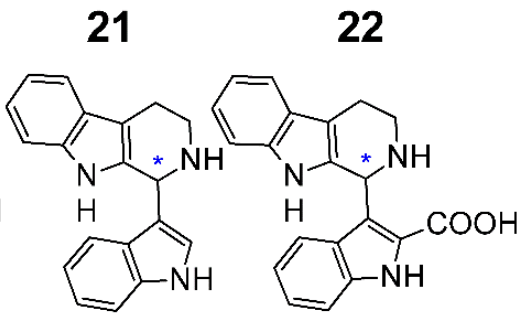

3-(1,2,3,4- 3- $(1,2,3,4-$ tetrahidro- 3 - tetrahidro- $\beta$-karbolin

karbolin-1-il)- -1-il)-indol-2indol karbonsav

7. ábra A vizsgált bázikus és amfolit indol vegyületek szerkezete 


\section{1,2,3,4-tetrahidroizokinolin és 1-naftol származékok}

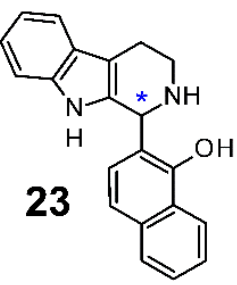

2-(1,2,3,4-tetrahidro- $\beta$ karbolin-1-il)-1-naftol

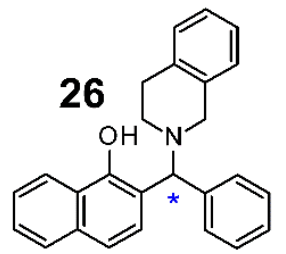

2-(2-benzil-1,2,3,4tetrahidroizokinolin)1-naftol

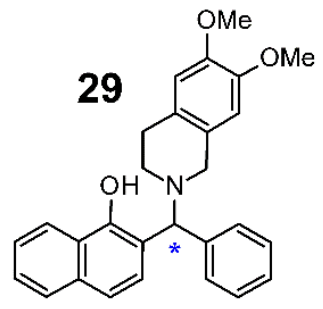

2-(2-benzil-6,7-dimetoxi- 2-(2-(4-klórbenzil)-6,7-dimetoxi1,2,3,4-tetrahidroizokinolin)- 1,2,3,4-tetrahidroizokinolin)1-naftol

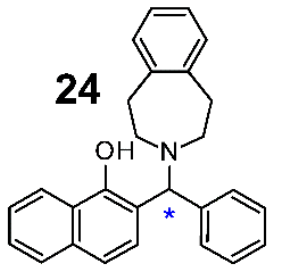

2-(3-benzil-2,3,4,5-tetrahidro$1 H$-benz[d]azepin)-1-naftol

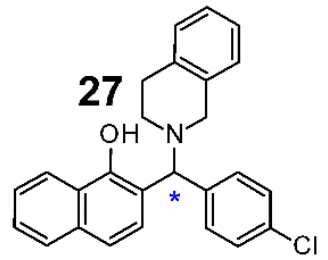

2-(2-(4-klórbenzil)-1,2,3,4tetrahidroizokinolin)1-naftol

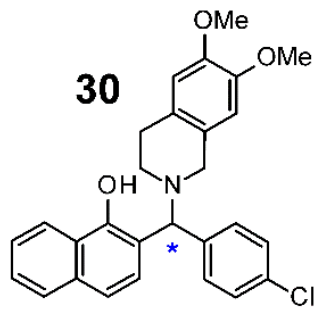

1-naftol<smiles>Oc1c([C@@H](c2ccccc2)N2CCc3ccccc3C2)ccc2ccccc12</smiles>

2-(3-benzil-2,3,4,5-tetrahidro$1 H$-benz[c]azepin)-1-naftol<smiles>COc1ccc([C@H](c2ccc3ccccc3c2O)N2Cc3ccccc3C2)cc1</smiles>

2-(2-(4-metoxibenzil)1,2,3,4-tetrahidroizokinolin)1-naftol<smiles>COc1ccc(C(c2ccc3ccccc3c2O)N2CCc3cc(OC)c(OC)cc3C2)cc1</smiles>

2-(2-(4-metoxibenzil)-6,7dimetoxi-1,2,3,4tetrahidroizokinolin)1-naftol

8. ábra A vizsgált tetrahidroizokinolin és 1-naftol származékok szerkezete

\subsection{Felhasznált vegyszerek}

Az alkalmazott HPLC tisztaságú oldószereket, savakat és bázisokat, $n$-hexán, acetonitril $(\mathrm{MeCN})$, metanol $(\mathrm{MeOH})$, etanol (EtOH), propán-1-ol (PrOH), propán-2-ol (2-PrOH), 1butanol $(\mathrm{BuOH}), 2$-metil-propán-2-ol $(t-\mathrm{BuOH})$, tetrahidrofurán (THF), etil-amin (EA), dietil-amin (DEA), dietanol-amin (DEOA), trietil-amin (TEA), hangyasav (FA), ecetsav $(\mathrm{AcOH})$ a VWR International (VWR International, Leuven, Belgium) forgalmazza. A felhasznált folyékony szén-dioxid élelmiszer-minőségü volt és a Messer Hungarogáz Kft. (Budapest, Magyarország) gyártotta.

\subsection{Alkalmazott berendezések}

Méréseim során három különböző kromatográfiás rendszert alkalmaztam:

Az I. rendszer egy 1100-as sorozatszámú Agilent Technologies (Waldbronn, Németország) HPLC volt, amelyet egy oldószer gázmentesítő, pumpa, automata 
mintaadagoló, kolonna termosztát, egy ötcsatornás UV-Vis-detektor és egy ESA Biosciences Inc. koronakisülési detektor (Corona CAD, Chelmsford, MA, USA) alkotott. Az adatok gyűjjtéséhez és kiértékeléséhez ChemStation adatfeldolgozó szoftvert használtam.

A II. rendszer Waters 1525 bináris HPLC pumpát, Waters kolonna termosztátot, Waters 2487 kétcsatornás UV-Vis-detektort, Waters 717 plus automata mintaadagolót és Empower 2 adatfeldolgozó szoftvert tartalmazott (Waters, Milford, MA, USA).

A III. rendszer egy Waters Acquity UPC ${ }^{2}$ (Waters Corporation, Milford, MA, USA) kromatográfiás rendszer volt, mellyel az SFC méréseket végeztem. Ezt a rendszert egy oldószer gázmentesítő, pumpa, automata mintaadagoló, kolonna termosztát, fotodióda soros detektor, egy szén-dioxid nyomásszabályzó és az Empower 2 adatfeldolgozó szoftver alkotja.

A hőmérsékletfüggés vizsgálata során vagy az említett kromatográfiás rendszerek termosztátját, vagy egy Alpha RA 8 (Lauda, Németország) folyadék termosztátot használtam. A tömegmérésekhez egy Pioneer PA 214 C (Ohaus, USA) digitális mérleget használtam. A minta oldás elősegítésére egy Rotring Sonic Cleaner ultrahangos fürdő (Rotring Gmbh, Hamburg, Németország) állt rendelkezésemre. Víztisztításhoz egy Ultrapure Water System, Puranity TU UV/UF (VWR International, Leuven, Belgium) rendszert használtam.

\subsection{Alkalmazott folyadékkromatográfiás állófázisok}

\section{Cinkóna alkaloid alapú állófázisok}

Cinkóna alkaloid alapú állófázist tartalmaznak a Chiral Technologies Europe (CTE, Illkirch, Franciaország), által forgalmazott Chiralpak $Q N-A X$, Chiralpak $Q D-A X$, Chiralpak ZWIX(+), Chiralpak ZWIX(-) oszlopok. A kolonnák fizikai paraméterei azonosak: $150 \mathrm{~mm}$ $\times 3,0 \mathrm{~mm}$, a szemcseátmérő $3 \mu \mathrm{m}$.

\section{Poliszacharid alapú állófázisok}

A kémiailag kötött poliszacharid típusú oszlopok szelektorai: Chiralpak IB, cellulóz trisz(3,5-dimetilfenilkarbamát); Chiralpak IC, cellulóz trisz-(3,5-diklórfenilkarbamát); Chiralpak IA, amilóz trisz-(3,5-dimetilfenilkarbamát), Chiralpak ID, amilóz trisz-(3-klórfenilkarbamát); Chiralpak IE, amilóz trisz-(3,5-diklórfenilkarbamát); Chiralpak IF, amilóz trisz-(3-klór-4-metilfenilkarbamát); Chiralpak IG, amilóz trisz-(3-klór-5metilfenilkarbamát). A poliszacharid alapú oszlopokat szintén a CTE forgalmazza, fizikai paramétereik: $250 \mathrm{~mm} \times 4,6 \mathrm{~mm}$, szemcseátmérő: $5 \mu \mathrm{m}$. 


\section{EREDMÉNYEK ÉS ÉRTÉKELÉSÜK}

Az értekezésben bemutatott eredmények két széles körben használt királis állófáziscsalád müködési mechanizmusainak mélyebb megismerésére szolgálnak. A cinkóna alkaloid alapú szelektorok ioncserélőként alakítanak ki hatékony, elsődleges kölcsönhatásokat az elválasztandó vegyületekkel, míg a poliszacharid alapú szelektorok jellemzően a semleges, ionizálható funkciós csoportokat nem tartalmazó vegyületek elválasztására használtak. Így kevés olyan alkalmas vegyület van, amely egyszerre vizsgálható az eltérő működési mechanizmusú szelektorokkal. Emellett fontos megjegyezni, hogy a királis felismerésért felelős számos kölcsönhatást csak változatos szerkezetű vegyületek felhasználásával lehet átfogóan tanulmányozni, így érthetővé válik, hogy miért nem vizsgáltam minden vegyületet az összes tanulmányozott állófázison.

A későbbiekben feltüntetett ábrák és táblázatok az ismételhetőséget jellemző szórást nem tartalmazzák. A vizsgált adatok általában két-három párhuzamos mérésből keletkeztek és a változások alapvető irányát mutatják be. Az így kapott adatok változása a meghatározó, ezért ezek eredete és eredményeinek elemzése szempontjából az egyes adatpontok szórása kevésbé releváns. Általánosságban kijelenthető, hogy a dolgozatban bemutatott kísérletek során a retenciós tényezők relatív szórása 2 - 4\%-os érték közé esett.

A vizsgált vegyületek néhány jellemző enantioszelektív elválasztását bemutató kromatogramok a függelék F10 és F11 ábrákon láthatók.

\subsection{A mozgófázis összetétel hatása a királis elválasztásra}

\subsubsection{A mozgófázis összetétel hatása a királis elválasztásra cinkóna alkaloid alapú szelektorok esetén}

A vizsgált királis szelektorok eltérő működési mechanizmusa miatt a mozgófázis összetételének érdemi hatását állófázis típusként különböző eluensek alkalmazásával lehet feltérképezni. A cinkóna alkaloid alapú állófázisokat jellemzően poláris-ionos módban (PIM) alkalmazzák, vagyis a mozgófázis fó alkotói poláris szerves oldószerek (pl.: $\mathrm{MeOH}$, $\mathrm{MeCN}$ ), melyekhez kis mennyiségben sav és/vagy bázis módosítókat, illetve vizet adhatnak. A $\mathrm{MeOH}$, protikus karaktere révén, jelentősen csökkentheti a szelektor és az elválasztandó komponensek között az ionos kölcsönhatások és a H-hidak kialakulását. Emellett a $\mathrm{MeOH}$ a poláris molekulákat könnyen szolvatálja, így mennyisége a mozgófázisban közvetlenül befolyásolhatja a retenciós időt. Ezzel szemben az aprotikus MeCN kevésbé jól oldja a poláros komponenseket, elősegíti az ionos és gyengítheti a $\pi$ - $\pi$ kölcsönhatások kialakulását. A $\mathrm{MeOH}$ és $\mathrm{MeCN}$ eltérően befolyásolják a kromatográfiás rendszerben kialakuló 
kölcsönhatásokat, ezért mozgófázisbeli arányukkal a vizsgált komponensek retenciója és az állófázis szelektivitása szabályozható. Az acetonitrilhez hasonlóan poláris aprotikus oldószerként használható a THF is, ha a $\mathrm{MeOH} / \mathrm{MeCN}$ rendszer nem biztosít megfelelő elválasztást [60].

Cinkóna alkaloid alapú állófázisok esetén, a mozgófázis összetételének elválasztásra gyakorolt hatását, biológiailag aktív dipeptidekkel, valamint bázikus és amfolit indol vegyületekkel vizsgáltam. Mozgófázisként poláris szerves oldószerek $(\mathrm{MeOH}, \mathrm{MeCN}$, THF) különböző arányú elegyét használtam, melyek sav és bázis módosítókat állandó koncentrációban tartalmaztak. Az ioncserélő állófázisok esetén, ha külön nincs feltüntetve, a mozgófázisban található sav koncentrációja kétszerese volt a hozzáadott bázis koncentrációjának, így a savfelesleg biztosította a vizsgált vegyületek és a szelektor megfelelő ionizációját.

\subsubsection{A kromatográfiás paraméterek változása a $\mathrm{MeOH} / \mathrm{MeCN} \quad 0-100$ v/v tartományban}

Az alanil-triptofán (11) dipeptid felhasználásával a $Z W I X(+)$ és $Z W I X(-)$ kolonna esetén megvizsgáltam milyen hatással van a kromatográfiás paraméterekre, ha a $\mathrm{MeOH} / \mathrm{MeCN}$ összetételt 0-100 v/v tartományban változtatom (9. ábra). A 9. ábrán látható, hogy kisebb, mint $20 \nu \% \mathrm{MeOH}$ tartalom esetén a visszatartás extrém mértékben növekszik, a szelektivitás jelentősen lecsökken, valamint az enantiomerek elválása fokozatosan megszünik. A visszatartás folyamatos növekedésének feltételezhetően az az oka, hogy a $\mathrm{MeOH}$ tartalom csökkenésével a vizsgált vegyületeket és a szelektort körülvevő szolvátburok vastagsága lecsökken, ezért az ionos kölcsönhatások felerösödnek. Mivel az ionos kölcsönhatások nem enantioszelektívek, ezért előtérbe kerülésükkel párhuzamosan a szelektivitás és a felbontás is lecsökken. A $Z W I X(+)$ és $Z W I X(-)$ oszlopokon mért eltérö szelektivitás és felbontás értékeket feltehetőleg sztérikus okok, illetve a diasztereomer viszonyban levő állófázisokon kialakuló H-híd és $\pi$ - $\pi$ kölcsönhatások eltérése okozzák.

A $20 v \%$-nál kisebb MeOH tartalom mellett jellemzően a $80 v \%$-ot meghaladó $\mathrm{MeOH}$ tartalom használata sem célszerü, mivel az gyakran drasztikusan lecsökkenti a vizsgált komponensek visszatartását. A túlzottan kicsi visszatartás nem kedvező, mert így az enantioszelektív kölcsönhatások is csak kevés ideig fejtik ki hatásukat. Ezért a többi vegyület vizsgálatakor, a mozgófázis jellemzően legalább $20 v \%$ és legfeljebb $80 v \%$ MeOH-t tartalmazott. 

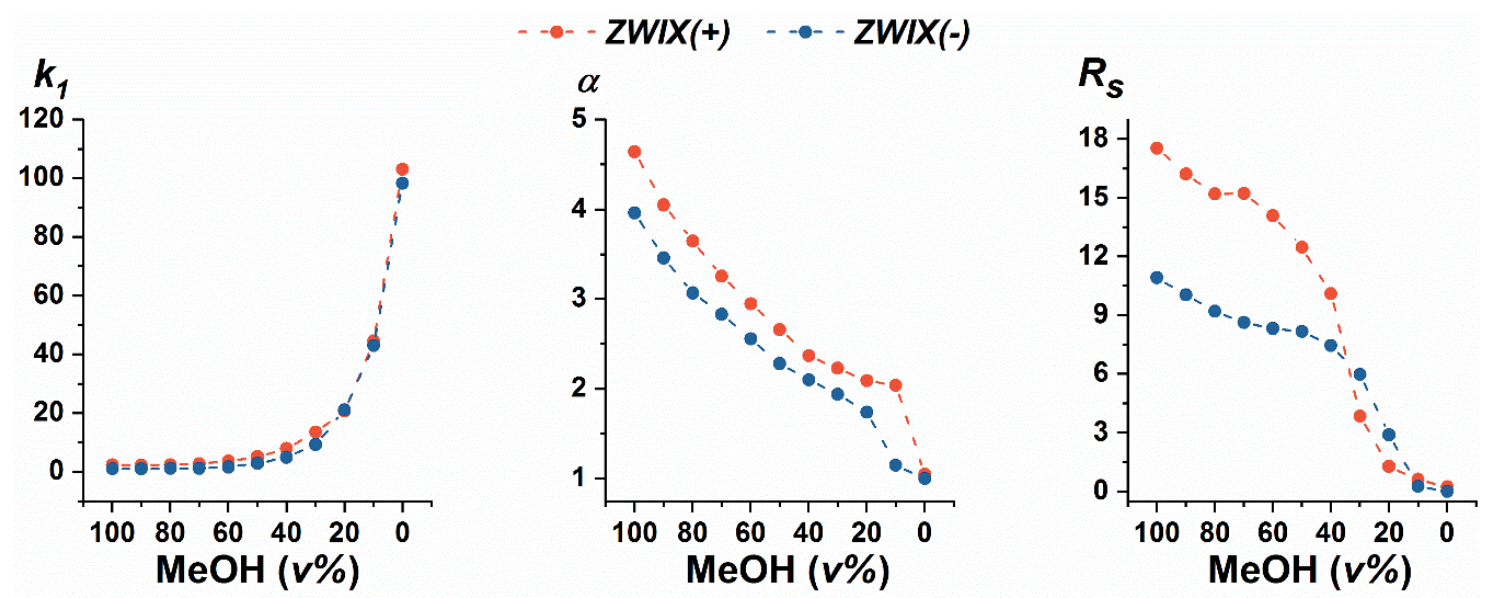

9. ábra A kromatográfiás paraméterek változása a teljes $\mathrm{MeOH} / \mathrm{MeCN}(100 / 0-0 / 100 v / v)$ mozgófázis összetétel tartomány esetén

Kromatográfiás körülmények: kolonna, ZWIX(+) és ZWIX(-); mozgófázis, MeOH/MeCN (100/0, 10/90, 20/80, 30/70, 40/60, 50/50, 60/40, 70/30, 80/20, 90/10, 0/100 v/v) és DEA (25 mM) és FA (50 mM); áramlási sebesség, $0,6 \mathrm{ml}$ perc ${ }^{-1}$; detektálás, $230 \mathrm{~nm}$; hőmérséklet, $25^{\circ} \mathrm{C}$; vizsgált vegyület, 11.

\subsubsection{A mozgófázis összetétel változtatás hatásának összehasonlítása ikerionos és monoionos állófázisok esetén}

A kinin alapú $Z W I X(+)$ és $Q N-A X$, valamint a kinidin alapú $Z W I X(-)$ és $Q D-A X$ kolonnák összehasonlításával megfigyelhető, hogy a mozgófázis összetételének változtatása milyen hatással van az enantoszelektivitásra az azonos alkaloidra épülő ikerionos és monoionos állófázisok esetén. Ennek vizsgálatára aromás és alifás dipeptideket választottam: (2) alanilfenilglicin, (6) $\beta$-alanil-fenilalanin, (9) alanil-tirozin, (11) alanil-triptofán, (16) leucil-leucin, a kapott eredményeket a 10. és F1 ábrán mutatom be.

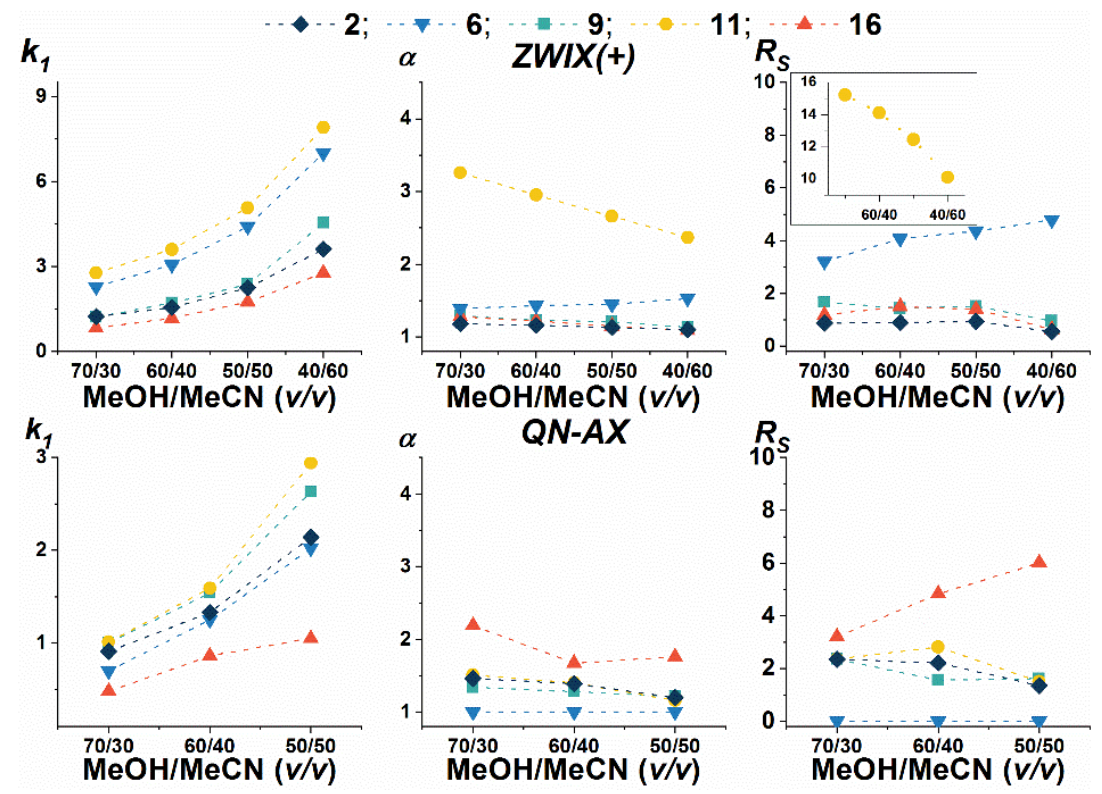

10. ábra $A$ kromatográfiás paraméterek változása kinin alapú állófázisok esetén

Kromatográfiás körülmények: kolonna, $Z W I X(+)$ és $Q N-A X$; mozgófázis, $Z W I X(+), \mathrm{MeOH} / \mathrm{MeCN}(70 / 30$, $60 / 40,50 / 50,40 / 60 v / v)$ és DEA (25 mM) és FA (50 mM), $Q N-A X, \mathrm{MeOH} / \mathrm{MeCN}(50 / 50,40 / 60,30 / 70 v / v)$ és DEA (25 mM) és FA (50 mM); áramlási sebesség, 0,6 ml perc ${ }^{-1}$; detektálás, $230 \mathrm{~nm}$; hömérséklet, $25^{\circ} \mathrm{C}$. 
A 10. és függelék F1 ábrán megfigyelhető, hogy a MeOH tartalom csökkenés hatására a visszatartás növekszik, a szelektivitás, kevés kivételtől eltekintve csökken vagy alig változik. Ezzel szemben a felbontás értékek vegyes tendenciákat követnek, ikerionos állófázisok esetén többnyire keveset változnak vagy csökkennek, míg monoionos állófázisok esetén növekvő értékek is előfordulnak. Emellett érdemes kiemelni, hogy ikerionos állófázisok esetén jelentősen nagyobb a vizsgált vegyületek visszatartása, mint monoionos állófázisok esetén. Azonban a nagyobb visszatartással együtt járó hosszabb kölcsönhatási idő a szelektor és az enantiomerek között, a később tárgyalt kivételektől eltekintve, nem okozott jelentős szelektivitás és felbontásbeli különbséget az ikerionos és monoionos állófázisok között. Ez a jelenség egyértelmüen alátámasztja, hogy az ikerionos állófázisok esetén nagyobb mértékben fellépő nem szelektív ionos kölcsönhatások önmagukban nem képesek javítani az enantioszelektivitást, ehhez más kölcsönhatásokra is szükség van.

$\mathrm{Az}$ ikerionos állófázisok kiemelkedő szelektivitással és felbontással rendelkeznek az alanil-triptofán (11) esetén, míg monoionos állófázisoknál ezek az értékek jellemzően nem különböznek számottevően a többi vegyület esetén tapasztaltaktól. Ez a dipeptid az egyetlen, amely kondenzált gyürüs aromás rendszert tartalmaz, ezért a $\pi$ - $\pi$ kölcsönhatások enantioszelektív irányító hatása itt tapasztalható a legnagyobb mértékben. Emellett a $\mathbf{1 1}$ dipeptid indolgyürüt tartalmaz, melynek szekunder aminocsoportja $\left(\mathrm{pK}_{\mathrm{s} \text { (aq.) }} \approx 16\right.$ [120]) protonálódik a mozgófázisban található sav hatására, így két, pozitív töltésü funkciós csoportja révén több lehetősége van ionos kölcsönhatások kialakítására az ikerionos állófázis negatív szulfonsavcsoportjával, mint a többi komponensnek. Ez a kétszeres pozitív töltés és a nagyméretű aromás oldallánc együttesen okozza a $\mathbf{1 1}$ vegyület hatékony enantiomer felismerését az ikerionos szelektorokon. Ezzel kapcsolatos, hogy az MeCN tartalom növekedésével a szelektivitás és a felbontás értékek jelentősen csökkennek a $\mathbf{1 1}$ dipeptid esetén ikerionos oszlopokon, amit feltehetően a $\pi$ - $\pi$ kölcsönhatások gyengülésének és a nem enantioszelektív ionos kölcsönhatások erösödésének együttes hatása okoz.

A leucil-leucin (16), mint alifás oldalláncú dipeptid, lehetővé teszi a kis méretü, aromás csoportot nem tartalmazó dipeptidek kromatográfiás tulajdonságainak tanulmányozását. A 10. ábrán megfigyelhető, hogy az ikerionos szelektorral a 16 vegyületre az aromás funkciós csoportot tartalmazó vegyületekhez hasonló szelektivitást és felbontást kaptam. Ettől eltérően monoionos szelektor esetén kiemelkedő a szelektivitás és felbontás értéke, mely a $\mathrm{MeOH}$ tartalom csökkentésével még növekvő tendenciát is mutat a $Q N-A X$ oszlopon. Ennek valószínűleg az az oka, hogy a molekula szerkezetéből adódó mozgékonysága megkönnyíti a szelektorhoz való kapcsolódását és az illeszkedést gátló sztérikus hatások lecsökkennek. 
Természetesen arról sem szabad megfeledkezni, hogy az anioncserélő állófázis szelektoráról hiányzó negatív töltésü funkciós csoport miatt az ionos kölcsönhatások kevésbé fejtik ki hatásukat. Az aromás csoport hiánya a visszatartás mértékében is megmutatkozik, a 16 leucil-leucin retenciója a legkisebb mind a négy állófázis esetén, függetlenül a mozgófázis összetételtöl.

Az ikerionos állófázisok számottevő szelektivitással és felbontással rendelkeznek a $6 \beta$ alanil-fenilalanin esetén, mely értékek a MeOH tartalom csökkentésével enyhén növekednek (10. ábra). Ezzel szemben a 6 dipeptid nem vált el a $Q N-A X$ oszlopon, míg a $Q D-A X$ oszlopon mért szelektivitás és felbontás értékek ennél a vegyületnél a legkisebbek, melyeken a mozgófázis összetétel változtatás sem módosít (függelék F1 ábra). A 6 dipeptid az $N$ terminálisán $\beta$-aminosavat tartalmaz, míg a többi vizsgált dipeptid $\alpha$-aminosavakból épül fel, így feltehetőleg ez az eltérő szerkezet okozza a kimagasló szelektivitás és felbontás értékeket az ikerionos állófázisokon. Ezt a megfigyelést kutatócsoportunk korábbi $\beta$ aminosavakkal végzett vizsgálatai is megerösítik [121-123]. Emellett a $\mathrm{MeOH}$ tartalom csökkenés hatására az ionos és H-híd kölcsönhatások is felerösödnek, melyek együttes hatása okozza a jelentős enantioszelektivitást. A monoionos állófázisok esetén a hiányzó negatív töltésü funkciós csoport miatt az ionos kölcsönhatások kevésbé érvényesülnek, valamint a dipeptidek $N$-terminálisán található pozitív töltésű funkciós csoport érdemben nem befolyásolja a királis felismerést. Ezt bizonyítja, hogy a mozgófázis összetétel változtatás monoionos szelektor esetén nem módosítja jelentősen a szelektivitást és felbontást.

$\mathrm{Az}$ ikerionos és monoionos kolonnák jellemzése során megvizsgáltam az oszlophatékonyságot jellemző elméleti tányérszám alakulását a mozgófázis összetétel változásának függvényében (függelék F1 táblázat). A felbontás számos esetben az elméleti tányérszám értékek változását követte, azonban előfordult ellentétes tendencia is, ami a szelektivitás és retenciós tényező hatásához köthető. MeCN-t tartalmazó eluens esetén általános tendencia nem figyelhető meg az elméleti tányérszám változásokra nézve.

\subsubsection{A tetrahidrofurán tartalom hatása a kromatográfiás paraméterekre}

Királis ioncserélő állófázisok esetén a THF használata, mint mozgófázis alkotó szerves oldószer, számos esetben vezetett a szelektivitás és felbontás növekedéséhez [60, 62, 124, 125]. Ezért dipeptid vegyületekkel megvizsgáltam, hogy milyen tendenciák figyelhetők meg kinin alapú $Z W I X(+)$ és $Q N-A X$, valamint a kinidin alapú $Z W I X(-)$ és $Q D-A X$ kolonnák esetén, ha $\mathrm{MeOH} / \mathrm{MeCN}$ helyett $\mathrm{MeOH} / \mathrm{THF}$ összetételü mozgófázist használok (11. és 
függelék F2 ábra). Az 5.1.1.2-es fejezethez hasonlóan a 2, 6, 9, 11, 16 dipeptideket tanulmányoztam a THF tartalmú eluensrendszerrel.
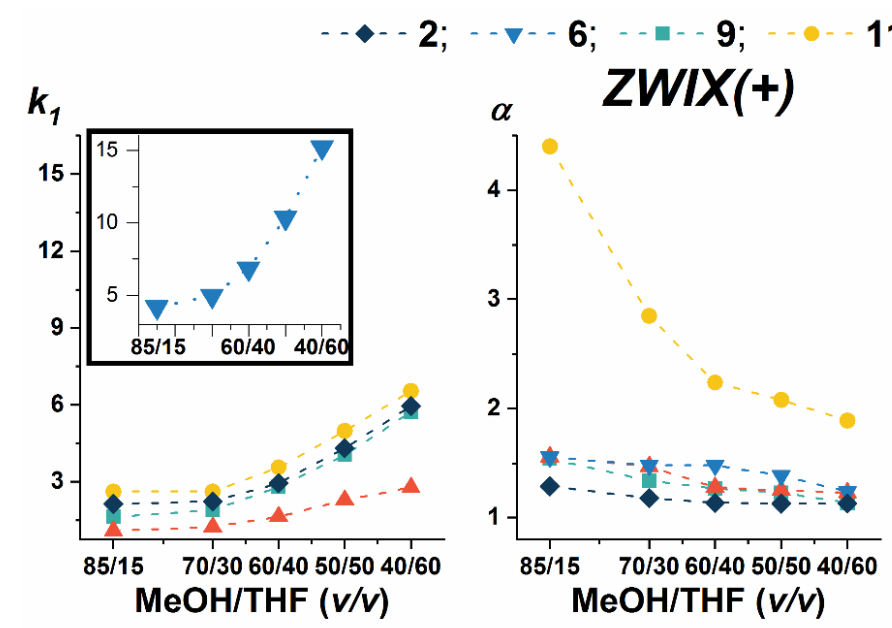

$11 ;-\cdots-16$
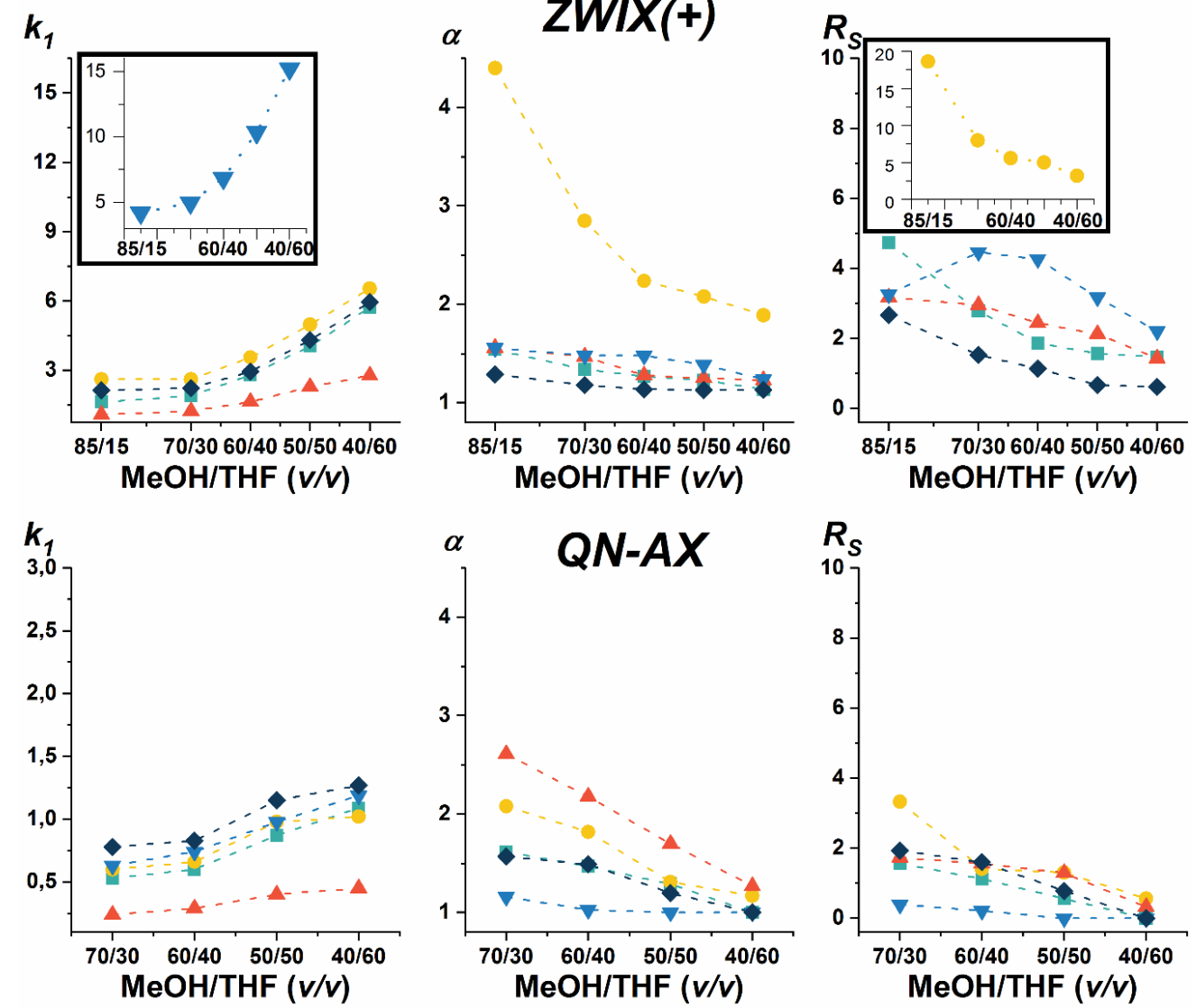

11. ábra $A T H F$ tartalom hatása a kromatográfiás paraméterek változására

Kromatográfiás körülmények: kolonna, ZWIX(+) és $Q N-A X$; mozgófázis, ZWIX(+) esetén MeOH/THF (85/15, 70/30, 60/40, 50/50, 40/60 v/v) és DEA (25 mM) és FA (50 mM), $Q N$-AX esetén MeOH/THF (70/30, 60/40, $50 / 50,40 / 60 v / v)$ és DEA $(25 \mathrm{mM})$ és FA $(50 \mathrm{mM})$; áramlási sebesség, $0,6 \mathrm{ml}^{\text {perc }}{ }^{-1}$; detektálás, $230 \mathrm{~nm}$; hömérséklet, $25^{\circ} \mathrm{C}$.

$A z$ 5.1.1.2. fejezetben bemutatott mérésekhez képest az ebben a fejezetben áttekintett mérések körülményei csak a mozgófázis összetételében térnek el, így a $\mathrm{MeOH} / \mathrm{MeCN}$ és a $\mathrm{MeOH/THF} \mathrm{mozgófázis} \mathrm{összetétel} \mathrm{változtatás} \mathrm{eredményei} \mathrm{összevethetők.} \mathrm{A} \mathrm{11.} \mathrm{és} \mathrm{függelék}$ F2 ábrán látható, hogy a THF tartalom növekedése mindegyik ioncserélő oszlopon az összes vizsgált anyag esetén a visszatartás növekedésével és a szelektivitás és felbontás csökkenésével jár együtt. Az eltérő szerkezetű vegyületek kromatográfiás paramétereinek változását tekintve összességében ugyanazok a tendenciák figyelhetők meg, mint a $\mathrm{MeOH} / \mathrm{MeCN}$ rendszer esetében, ami a kromatográfiás rendszerben kialakuló kölcsönhatások hasonlóságát támasztja alá. 
A MeCN-nél tapasztaltakhoz képest eltérésként figyelhető meg a $6 \beta$-alanil-fenilalanin jelentősen nagyobb visszatartása ikerionos állófázisokon THF használata esetén, amit valószínüleg a szolvatációs viszonyok különbözősége és sztérikus hatások okoznak. További eltérést jelent a $Q N-A X$ oszlopon a $\mathbf{1 6}$ alifás leucil-leucin szelektivitás és felbontás értékeinek változása. A 16 dipeptid THF-nal történő mérése során nem különbözik jelentősen a monoionos és ikerionos állófázisok szelektivitás és felbontás értékei. Emellett THF esetén, azonos állófázison összehasonlítva a szelektivitás és felbontás értékeket az alifás és aromás oldalláncú dipeptidek esetén nem tapasztalható jelentős különbség. Ez alól egyedül a $\mathbf{1 1}$ dipeptid ZWIX(+) oszlopon tapasztalt kromatográfiás viselkedése jelentett kivételt.

A THF alkalmazása esetén is megvizsgáltam az eluensösszetétel változtatás hatását az elméleti tányérszám értékekre, ennek adatai a függelék F2 táblázatban találhatók. Áttekintve az adatokat, a felbontás értékek szinte kivétel nélkül az elméleti tányérszám értékekkel együtt változtak, vagyis a THF tartalom növekedésével csökkent az oszlop hatékonyság. Tehát a szakirodalomban leírtakhoz képest az általam vizsgált vegyületek esetén nem tapasztalható, hogy az eluens THF tartalmának növelése az ioncserélő állófázisok királis elválasztóképességét érdemben javítaná.

\subsubsection{Az eluensösszetétel hatása az elválasztásra poliszacharid alapú szelektorok esetén}

A hordozó felületéhez kémiailag kötött módosított poliszacharid alapú kolonnák jelenleg négyféle típusú mozgófázissal használhatók: normál fázisú, fordított fázisú, poláris-szerves és folyékony szén-dioxidot tartalmazó [40]. Mindegyik eluensrendszer egymástól eltérő előnyökkel és hátrányokkal rendelkezik, közülük leggyakrabban a normál fázisú körülményeket alkalmazzák. Normál fázisú mozgófázis esetén a fő komponens jellemzően apoláros szénhidrogén (pl.: n-hexán, n-heptán), melyhez kis molekulatömegü alkoholt, tetrahidrofuránt vagy egyéb módosítót adnak [86]. Emellett gyakori, hogy kis mennyiségben (1 v\% alatt) alkil-amint adnak az eluenshez. Ennek az az oka, hogy a szilikagél hordozó felületén lévő szabad szilanolcsoportok felületén az aminocsoportot tartalmazó komponensek megkötődhetnek, így ezek elúciós profilja torzulhat. Az alkil-amin hozzáadásával a szilanolcsoportok szabad kötőhelyei telíthetők, így a vizsgált komponensekkel nem lépnek kölcsönhatásba.

A poliszacharid alapú állófázisok esetén a mozgófázis összetételének hatását bázikus indol, valamint 1-naftol származékokkal vizsgáltam. Irodalmi ismeretek alapján a mozgófázishoz HPLC technika esetén $0,1 v \%$, SFC technika esetén 20 mM DEA-t adtam. 


\subsubsection{A mozgófázis alkotók anyagi minőségének hatása az elválasztásra}

A kromatográfiás paraméterek változását a 21 és $\mathbf{2 3}$ vegyületek Chiralpak $I A$ és $I B$ állófázisokon való elválasztásával vizsgáltam. A 21 és a $\mathbf{2 3}$ vegyületek szerkezetének az alapja az 1,2,3,4-tetrahidro- $\beta$-karbolin molekula, melyhez a 21 esetén indol, míg a $\mathbf{2 3}$ vegyület esetén 1-naftol van kapcsolva. Az IA oszlop szelektora amilóz, míg az IB oszlopé cellulóz alapú, melyek trisz-(3,5-dimetilfenil-karbamát) módosítót tartalmaznak. A mozgófázist alkotó alkohol anyagi minőségének hatását EtOH, 1-PrOH, 2-PrOH, BuOH és $t$ - $\mathrm{BuOH}$ felhasználásával vizsgáltam, ennek eredményei a 12. és függelék F3 ábrán láthatók.
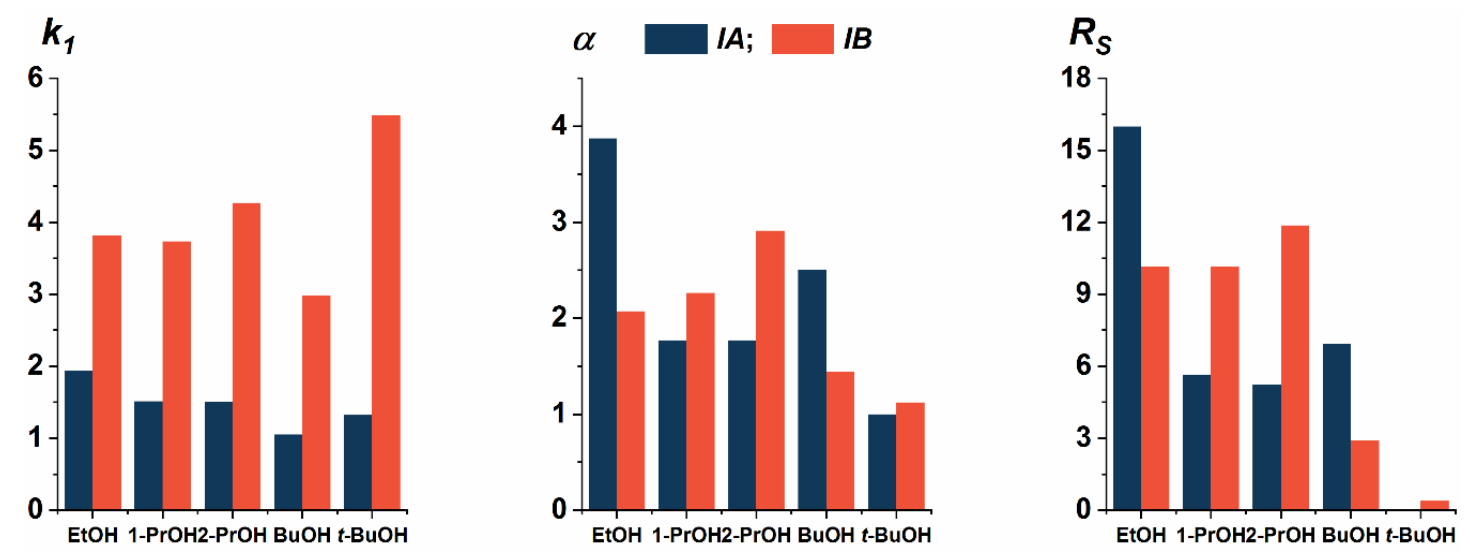

12. ábra $A z$ alkohol anyagi minőségének hatása a kromatográfiás paraméterekre a $\mathbf{2 3}$ vegyület esetén

Kromatográfiás körülmények: kolonna, $I A, I B$; mozgófázis, $n$-hexán/alkohol/DEA $(70 / 30 / 0,1 v / v / v)$; áramlási sebesség, 1,0 ml perc ${ }^{-1}$; detektálás, 215-250 nm; hőmérséklet, szobahőmérséklet.

Mindkét vegyület esetén megfigyelhető, hogy a cellulóz alapú állófázison a visszatartás szinte minden esetben nagyobb, mint az amilóz alapú szelektoron. Emellett a $\mathbf{2 3}$ vegyület $k_{l}$ értéke minden vizsgált alkohol esetén több, mint kétszerese az IB kolonnán, mint az $I A$ kolonnán. Ezt a számottevő retenciós különbséget feltehetően a poliszacharidok térszerkezetének különbözősége okozza. A helikális amilóz alapú IA kolonna esetén a $\mathbf{2 3}$ vegyület kevésbé tud hozzáférni a szelektorhoz, mint a lineáris szerkezetü $I B$-n, ezért kisebb a visszatartás.

Megfigyelhető, hogy az alkohol szénláncának növekedésével (EtOH, 1-PrOH, BuOH) a visszatartás enyhén csökkent mindkét kolonnán, mindkét vizsgált komponens esetén. Ez a viselkedés azzal magyarázható, hogy a szénlánc hosszának növekedésével az alkohol polaritása csökken, így jobban képes szolvatálni a jellemzően apoláros szerkezetü vegyületeket, így csökken az állófázison eltöltött idejük. Az $I B$ kolonna esetén megfigyelhető, hogy az alkohol rendüségének növekedésével (EtOH, 2-PrOH, $t$-BuOH) a $k_{l}$ 
értéke növekszik, a $t$-BuOH esetén kimagasló értéket elérve. Ez a változás feltehetőleg a magasabb rendü alkoholok csökkenő szolvatáló képességéből ered.

A szelektivitást vizsgálva látható, hogy mindkét vegyület esetén az IA oszlop kimagasló értékkel rendelkezik EtOH használatakor, valamint a 21 vegyületet esetén, a szelektivitás értéke az alkohol anyagi minőségétől függetlenül viszonylag szük tartományban mozog. A szelektivitás változást többek között az egyre apolárosabb alkoholok növekvő szolvatációs készsége, illetve a királis felismerésben fontos szerepet betöltő királis üregek környezetének megváltoztatása okozza [126, 127]. Vagyis az egyenes, illetve elágazó szénláncú alkoholok eltérő mértékben és módon változtatják meg a poliszacharid szelektor szerkezetét. Ennek hatására a felbontás értékek is jelentősen változnak az alkalmazott alkoholtól függően. Ezért a mozgófázisban található alkohol minősége és mennyisége egyaránt előre nem jelezhető módon képes alakítani a szelektor enantiomerfelismerő-képességét. Ez az észrevétel egyezik a poliszacharid alapú állófázisok normál fázisú használatáról leírtakkal [128, 129]. Az általunk vizsgált vegyületeknél az EtOH és a 2-PrOH alkalmazása eredményezte a leghatékonyabb elválasztást.

\subsubsection{A mozgófázis összetétel hatása a kromatográfiás paraméterekre}

Az eluens alkoholtartalmának elválasztásra gyakorolt hatását szintén a 21 (indol) és $\mathbf{2 3}$ (1-naftol) vegyületekkel vizsgáltam. Állófázisként az amilóz alapú Chiralpak $I A, I E$ és $I G$ oszlopokat választottam. Így összehasonlítható, hogy azonos alapszerkezetü poliszacharidok milyen hatást fejtenek ki az elválasztásra a fenil-karbamát szubsztituensek módosítása révén: $I A$ - trisz-(3,5-dimetilfenil-karbamát; IG - trisz-(3-klór-5-metilfenil-karbamát); IE trisz-(3,5-diklórfenil-karbamát). Eluensként az 5.1.2.1. fejezetben leírtak alapján a $n$ hexán/2-PrOH összetételü mozgófázist használtam 0,1 v\% DEA tartalommal. Az így kapott eredmények a 13. ábrán láthatók.

A visszatartást tekintve tipikus normál fázisú kromatográfiás viselkedés figyelhető meg, vagyis az apoláris $n$-hexán tartalom növelése az elúciós idők jelentős növekedését okozta. Emellett jól megfigyelhető mindkét vegyület esetén, hogy a szelektoron található klór szubsztituens számának csökkentése növeli a visszatartást, $k_{l}$ : $I E<I G<I A$.

A szelektivitás értékek a 21 anyagnál alig változtak, a 23 vegyület esetén jelentősen, míg a felbontás értékek mindkét anyag esetén növekedtek a hexán tartalommal. Bár a retenciós idő mindkét vegyület esetén az $I A$ kolonnán a legnagyobb, azonban az $I G$ oszlop eredményezte a legnagyobb szelektivitás és felbontás érték növekedést. 

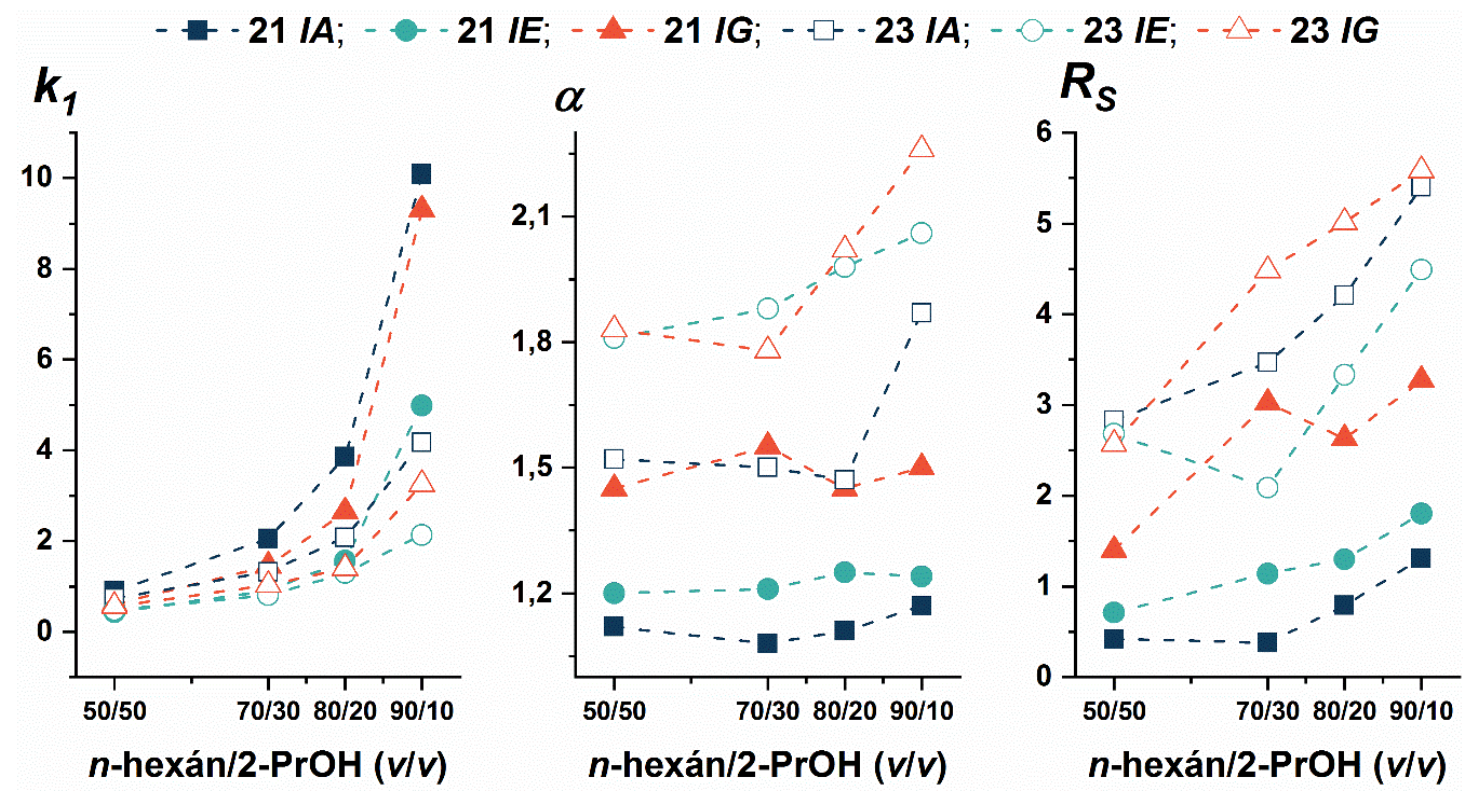

13. ábra Az eluensösszetétel hatása az elválasztásra poliszacharid alapú állófázisok esetén Kromatográfiás körülmények: kolonna, $I A, I E, I G$; mozgófázis, $n$-hexán/2-PrOH (50/50, 70/30, 80/20, 90/10 $v / v)$ és DEA (0,1 v\%); áramlási sebesség, $1,0 \mathrm{ml} \mathrm{perc}^{-1}$; detektálás $215-250 \mathrm{~nm}$; hőmérséklet, szobahőmérséklet.

\subsubsection{A mozgófázis összetétel hatása SFC technika esetén}

\subsubsection{Az SFC és HPLC technika mozgófázis összetétel hatásának összehasonlítása} cinkóna alkaloid alapú szelektorok esetén

Az SFC technika királis elválasztásra való használata kiemelkedő népszerüséggel bír az királis gyógyszervegyületek, illetve a természetben előforduló gyógyhatású anyagok vizsgálata során [65]. A királis vegyületek elválasztására SFC technika és cinkóna alkaloid alapú állófázisok alkalmazásával néhány esetben korábban már sor került $[66,130,131]$. A cinkóna alkaloid alapú állófázisok müködésének mélyebb megismerését segíti, ha megfelelő vegyületek alkalmazásával megvizsgáljuk az SFC és HPLC technika esetén a kromatográfiás viselkedést.

A mozgófázis összetétel változtatás hatásának összehasonlítását SFC és HPLC technika esetén a 17 bázikus és 18 amfolit indol analógokkal $Z W I X(+)$ és $Z W I X(-)$ oszlopokon végeztem el (14. ábra). 

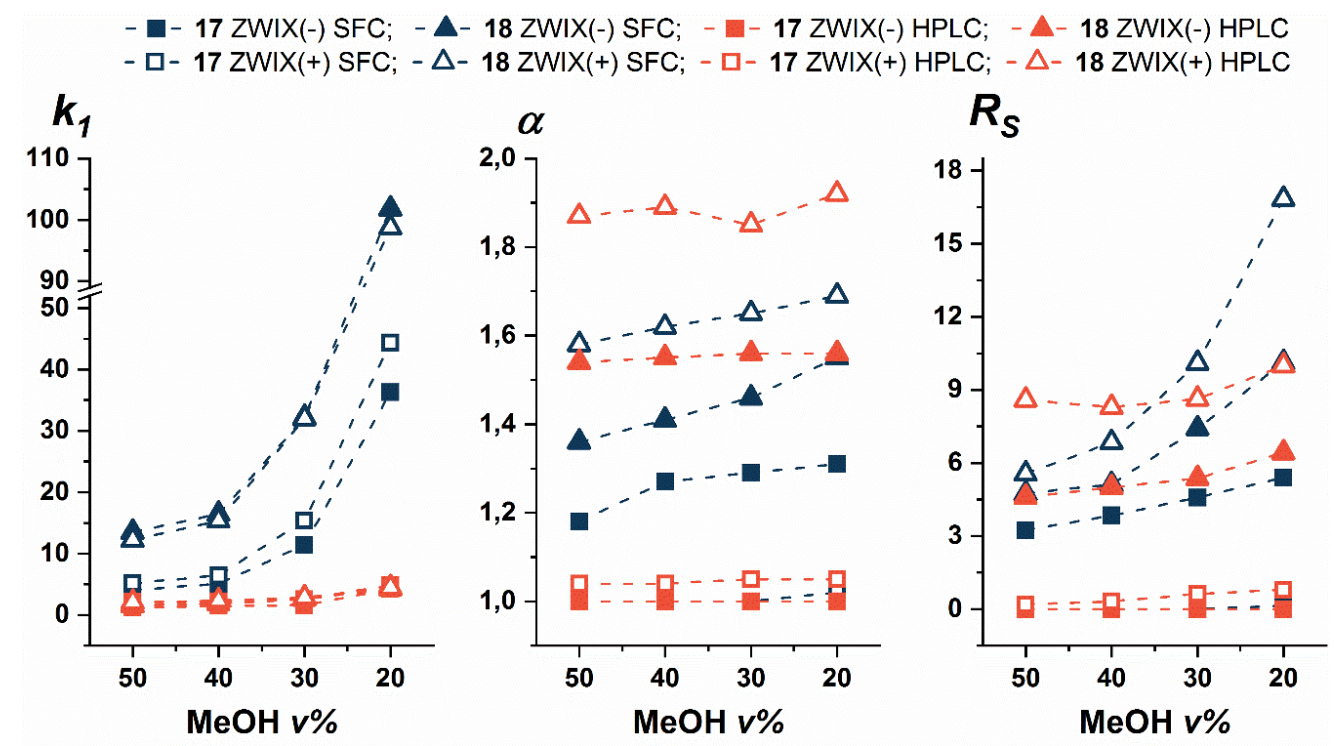

14. ábra SFC és HPLC eluensösszetétel változtatás hatása az elválasztásra

Kromatográfiás körülmények: kolonna, $Z W I X(+)$ és $Z W I X(-)$; mozgófázis, HPLC esetén, MeOH/MeCN (50/50, 40/60, 30/70, 20/80 v/v) és DEA (30 mM) és FA (60 mM), SFC esetén, $\mathrm{MeOH} / \mathrm{CO}_{2}(50 / 50,40 / 60$, 30/70, 20/80 v/v) és DEA (30 mM) és FA (60 mM); áramlási sebesség, HPLC esetén, 0,6 $\mathrm{ml}^{\text {perc }}{ }^{-1}$, SFC esetén 2,0 $\mathrm{ml} \mathrm{perc}^{-1}$; detektálás, $215-250 \mathrm{~nm}$; hömérséklet, HPLC esetén szobahömérséklet, SFC esetén $40^{\circ} \mathrm{C}$; SFC ellennyomás, 150 bar.

A 14. ábrán megfigyelhető, hogy a metanol tartalom csökkenésével a visszatartás minden esetben növekszik, ami egyezik a korábbi vizsgálatok eredményeivel [125, 131]. Ez a növekedés az SFC technika esetén kiváltképp drasztikus, a $k_{1}$ érték közel 10-szeresére növekszik a MeOH tartalom 30 v\%-os csökkentésével. A visszatartás növekedést feltehetőleg ugyanazok a kölcsönhatások okozzák mindkét technikánál, a MeOH tartalom csökkenésével az ionos kölcsönhatások felerősödnek. Az ionos kölcsönhatások meghatározó szerepét támasztja alá az is, hogy a cinkóna alkaloid szerkezetétől függetlenül, a karboxilcsoportot tartalmazó 18 anyag esetén figyelhető meg a legnagyobb visszatartás. Míg a HPLC technika esetén nincs jelentős különbség a bázikus és amfolit komponensek visszatartásában, addig az SFC esetén a bázikus komponens visszatartása minden esetben kisebb, mint az amfolité. Ezt feltehetően a kettős ionpár kölcsönhatás SFC körülmények közötti felerösödése okozza.

A szelektivitást és a felbontást vizsgálva jellemzően alig változtak az értékek vagy kis mértékben javultak a $\mathrm{MeOH}$ tartalom csökkenésével. A javuló elválásokat valószínűleg a MeOH tartalom csökkenés hatására felerősödő H-híd kölcsönhatások okozzák. Egyedül a 18 anyag felbontás értéke változott jelentősen SFC technika esetén. Itt észrevehető, hogy a karboxilcsoport jelenlétéböl adódó kölcsönhatások nagyobb hatással vannak az elválasztásra SFC technika esetén, mint a HPLC technikánál. Emellett, bár az SFC és a HPLC technika $k_{l}$ 
értékei majdnem egy nagyságrendben különböznek, azonban a szelektivitás és felbontás értékek sokkal kisebb tartományban változnak. További különbség a HPLC és SFC eredmények között, hogy a 17 bázikus indol vegyület HPLC esetén nem vagy csak alig válik el, míg SFC esetén ZWIX(-) oszlopon jól elválasztható. Vagyis az ikerionos ZWIX kolonna képes jó hatásfokkal kationcserélőként működni SFC körülmények között. Emellett megfigyelhető, hogy a $\mathbf{1 8}$ amfolit komponensre meghatározott szelektivitás és felbontás értékek minden esetben nagyobbak, mint a 17 bázikus komponens esetén tapasztaltak. Ez szintén a karboxilcsoport enantioszelektivitást növelö hatásáról árulkodik az ikerionos szelektorok esetén.

Összehasonlítva a HPLC és SFC adatokat ugyanarra a komponensre nézve, a $\mathbf{1 7}$ anyag esetén egyedül a $Z W I X(-)$ oszlopon SFC körülmények esetén tapasztalható kiugró szelektivitás és felbontás. Ezzel szemben, a $\mathbf{1 8}$ komponensnél a HPLC technika nagyobb szelektivitást eredményez, mint az SFC technika.

\subsubsection{Az SFC mozgófázis alkotók anyagi minőségének vizsgálata poliszacharid alapú} állófázisok esetén

Az SFC és HPLC technika királis elválasztásra való alkalmazását a legtöbb esetben a normál fázisú körülmények között, poliszacharid alapú állófázisokon hasonlították össze [66]. Ennek egyrészt a poliszacharid alapú állófázisok széleskörü elterjedtsége az oka, illetve, az a kézenfekvő feltételezés, hogy a hexán és a szén-dioxid apoláris oldószerként hasonló kromatográfiás viselkedést mutatnak. Ez a népszerü feltételezés azonban nem minden esetben egyezik a valósággal. A poliszacharid alapú szelektorok esetén az eltérő típusú eluens alapjaiban változtathatja meg az enantioszelektivitásért felelős kölcsönhatásokat [132]. Ezért a poliszacharid alapú állófázisok elválasztási sajátságainak SFC technikával történő vizsgálatakor nem törekedtem a normál fázisú körülmények lehető legpontosabb megismétlésére, inkább az SFC technika során fellépő egyedi kromatográfiás jelenségek mögött meghúzódó összetett mechanizmusok felderítését helyeztem előtérbe.

Az SFC mozgófázist alkotó alkohol anyagi minőségének hatását az elválasztásra a 21 és 23 vegyületekkel az amilóz alapú $I A, I E$ és $I G$ állófázisokon vizsgáltam $\mathrm{MeOH}, \mathrm{EtOH}, 1$ PrOH és 2-PrOH felhasználásával (15. és függelék F4 ábra). 

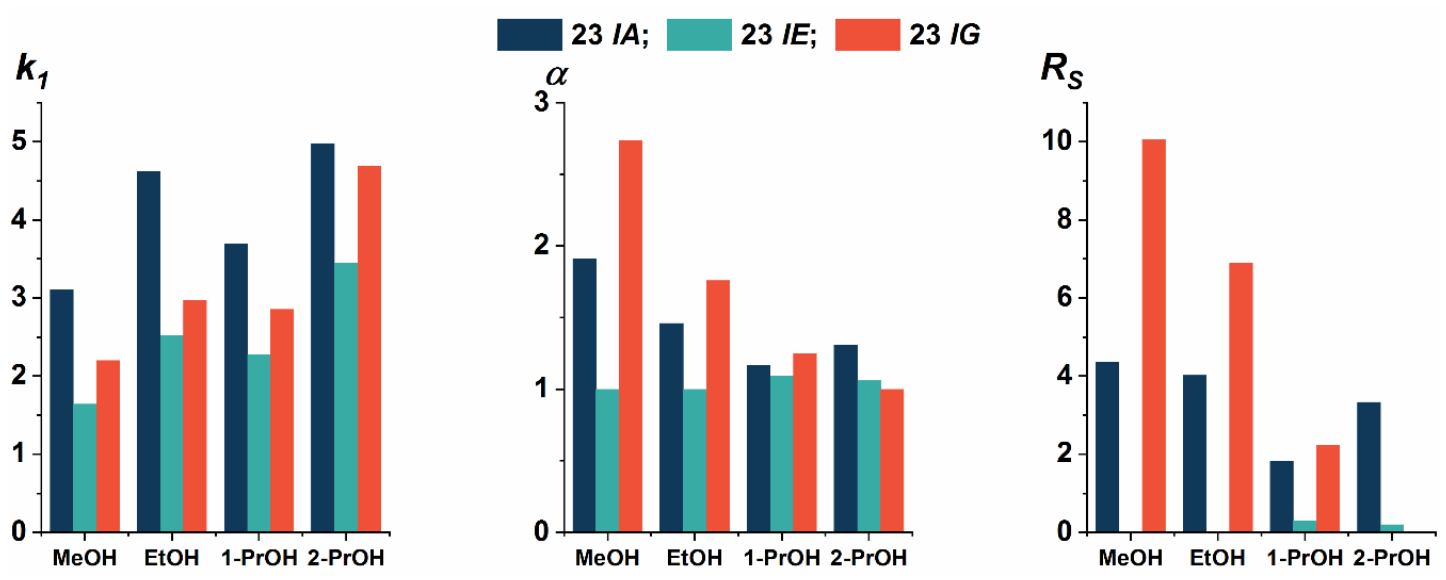

15. ábra Az SFC mozgófázist alkotó alkohol anyagi minőségének hatása az elválasztásra Kromatográfiás körülmények: kolonna, $I A, I E, I G$; mozgófázis, $\mathrm{MeOH} / \mathrm{CO}_{2}(50 / 50 v / v)$ és DEA $(20 \mathrm{mM})$; áramlási sebesség, $2,0 \mathrm{ml}_{\text {perc }}^{-1}$; detektálás, $215-250 \mathrm{~nm}$; hőmérséklet, $40^{\circ} \mathrm{C}$; ellennyomás 150 bar.

A 15. és függelék $\mathbf{F} 4$ ábrán látható, hogy mindkét anyag esetén oszloponként jelentősen eltérők a kromatográfiás adatok. Általánosságban elmondható, hogy a trisz-3,5-dimetilfenilkarbamát módosítót tartalmazó IA oszlopon volt a legnagyobb a komponensek visszatartása, valamint, hogy kevés kivételtől eltekintve, a visszatartás $I E<I G<I A$ sorrendben növekedett. Vagyis a szelektort módosító metilcsoportok számának növekedésével párhuzamosan nött a visszatartás. A metilcsoportok számának növekedésével apolárisabbá válik az állófázis, ami a szintén apoláris karakterü molekulák stabilabb megkötődéséhez vezet.

A szelektivitást és felbontást vizsgálva, kevés általános érvényű megállapítást lehet tenni. Jellemzően a MeOH alkalmazásakor figyelhető meg a legnagyobb szelektivitás, továbbá az IE oszlop esetén az alkohol minőségétől szinte függetlenül alig jelentkezik királis felismerés mind a 23, mind a 21 vegyületnél. Az $I A$ és $I G$ kolonnán a 23 , illetve az $I G$ kolonnán a 21 anyagot vizsgálva egyaránt megfigyelhető, hogy az alkohol szénlánc hosszának vagy elágazásainak növelése a szelektivitás csökkenését okozza. Ennek az az oka, hogy az alkohol polaritását csökkenti a szénlánc hosszának, illetve az elágazások számának növekedte. Mivel az eluenst alkotó alkohol polaritása hatással van a poliszacharid lánc, illetve a vizsgált komponensek szolvatációjára, illetve a királis felismerésben résztvevő királis üregek kialakulására, így a polaritás változás közvetlen hatással van a szelektivitásra $[126,127]$. A felbontás értékek a szelektivitáshoz hasonlóan változnak és az $I A$ és $I G$ oszlop esetén kimagasló hatékonyság is elérhető. Tehát a poliszacharid alapú állófázisok használatakor az SFC technika alkalmazása esetén is igaz, hogy az eluensben található alkohol anyagi minősége képes megváltoztatni a szelektor elválasztási sajátságait. 
A normál fázisú mozgófázis esetén kapott eredményekkel (12. és függelék F3 ábra) összehasonlítva az SFC technikával kapott adatokat, látható, hogy azonos állófázis és vizsgált vegyület alkalmazása ellenére az alkohol anyagi minősége eltérő hatást fejt ki a két technika esetén. Erre példa, hogy az EtOH kimagasló szelektivitást és felbontást eredményez normál fázisú körülmények között az IA oszlopon, míg SFC esetén a MeOH és a 2-PrOH is hasonló vagy akár nagyobb enantioszelektivitást biztosít. Továbbá, míg normál fázis esetén az eluenshez adott alkohol polaritásának csökkenése a szelektivitás növekedését okozta (pl.: 23 vegyület $I B$ oszlop EtOH, 1-PrOH, 2-PrOH), SFC technika alkalmazásakor ennek ellenkezője tapasztalható. Vagyis a királis vegyületek poliszacharid alapú állófázison SFC technikával való elválasztásakor nem lehet kizárólag a széleskörben használt normál fázisú eluenssel végzett mérések alapján előre jelezni az elválasztás mértékét.

Poliszacharid alapú állófázisok SFC technikával történő alkalmazása esetén is igaz, hogy a csúcsalakot javíthatja megfelelő alkil-amin mozgófázishoz történő adagolása [133]. SFC technika esetén a szén-dioxid tartalom miatt gyakran savas karakterü a mozgófázis (látszólagos $\mathrm{pH} \approx 5$ [81]), melyet a kromatográfiában megszokott kis mennyiségben hozzáadott bázis nem képes lúgos kémhatásra változtatni, inkább csak a látszólagos $\mathrm{pH}$ értéket stabilizálja [134]. A hozzáadott bázis mennyiségének hatását széles tartományban vizsgálták és így jelentős hatékonyságnövekedés volt tapasztalható [135]. Azonban érdemes megemlíteni, hogy a hozzáadott bázis anyagi minőségének is változatos hatása lehet a kromatográfiás rendszerre [136, 137].

Az SFC mozgófázishoz adott bázis anyagi minőségének hatását a kromatográfiás sajátságokra $I A, I E$ és $I G$ állófázisokon a 21 és $\mathbf{2 3}$ vegyületekkel EA, DEA, TEA és DEOA bázisok felhasználásával vizsgáltam (16. és függelék F5 ábra). A mozgófázist alkotó alkoholnak az előzőekben tárgyalt eredmények alapján a MeOH-t választottam.
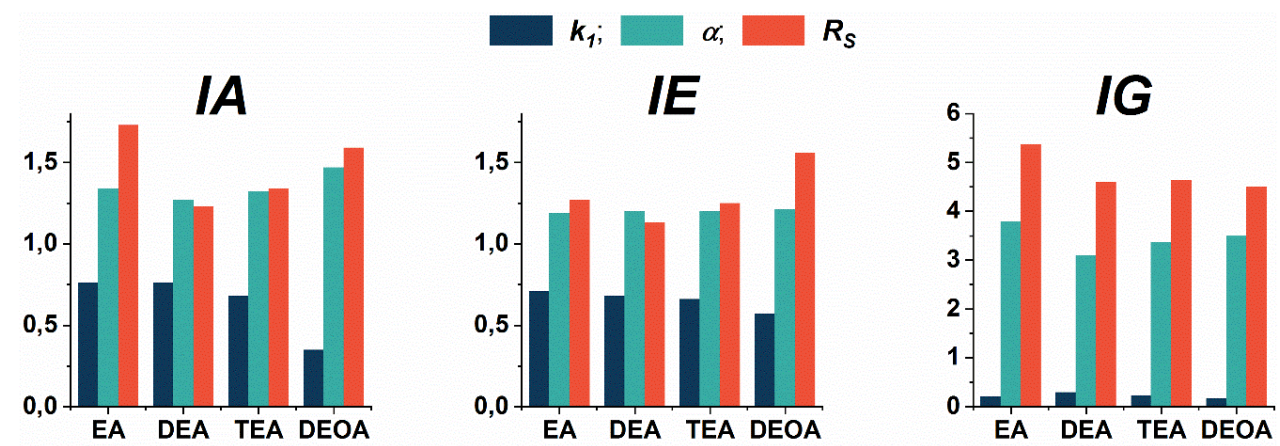

16. ábra $\mathrm{Az}$ SFC mozgófázishoz adott alkil-aminok anyagi minőségének hatása az elválasztásra a $\mathbf{2 1}$ vegyület esetén

Kromatográfiás körülmények: kolonna, $I A, I E, I G$; mozgófázis, $\mathrm{MeOH} / \mathrm{CO}_{2}(50 / 50 v / v)$ és EA vagy DEA vagy TEA vagy DEOA (20 mM); áramlási sebesség, $2,0 \mathrm{ml}$ perc ${ }^{-1}$; detektálás $215-250 \mathrm{~nm}$; hömérséklet, $40{ }^{\circ} \mathrm{C}$; ellennyomás 150 bar. 
A 16. és függelék $\mathbf{F 5}$ ábrán látható, hogy az alkalmazott bázisok, a szerkezetüktől gyakorlatilag függetlenül, az adott állófázison szinte minden esetben nagyon hasonló kromatográfiás eredményeket adtak. Kimagasló felbontást tapasztaltam az IA oszlopon DEOA alkalmazása esetén a $\mathbf{2 3}$ anyagra, azonban ugyanez a bázis az $I G$ oszlopon már sokkal rosszabb felbontást eredményez. Általánosságban elmondható, hogy a legkisebb felbontás minden bázis esetén az IE oszlopon volt megfigyelhetö, a $\mathbf{2 3}$ vegyület esetén ezen az oszlopon nincs királis felismerés. Mindkét vegyület esetén az $I G$ oszlopon kiemelkedően nagy felbontás érhető el, ezt a vizsgált bázisok anyagi minősége érdemben nem befolyásolja. Összevetve az alkalmazott szelektor szerkezetét és az eluensben található bázis anyagi minőségét, nem tapasztalható, hogy a kromatográfiás paraméterek egyértelmű trenddel leírható módon változnának. Tapasztalataim alapján kijelenthető, hogy az általam vizsgált vegyületek esetén az SFC mozgófázishoz adott kis molekulatömegü alkil-amin bázisok anyagi minősége poliszacharid alapú szelektorok alkalmazásakor az elválasztási tulajdonságokat érdemben nem befolyásolja, de adagolásuk mindenképp szükséges a torzításmentes csúcsalak eléréséhez.

\subsubsection{Az SFC mozgófázis összetétel hatása az enantioszelektivitásra poliszacharid alapú állófázisok esetén}

Az SFC mozgófázis alkotók anyagi minőségének hatása mellett a mozgófázis összetétel hatását is megvizsgáltam a poliszacharid alapú állófázisok SFC technikával történő használata esetén. Mozgófázisnak az 5.1.3.2. fejezetben bemutatott eredmények alapján a $\mathrm{MeOH} / \mathrm{CO}_{2}$ eluensrendszert választottam, melyhez $20 \mathrm{mM}$ DEA-t adtam. A 21 és 23 anyagot használva az elválasztásokat amilóz alapú $I A, I E$ és $I G$ állófázisokon vizsgáltam (17. ábra).
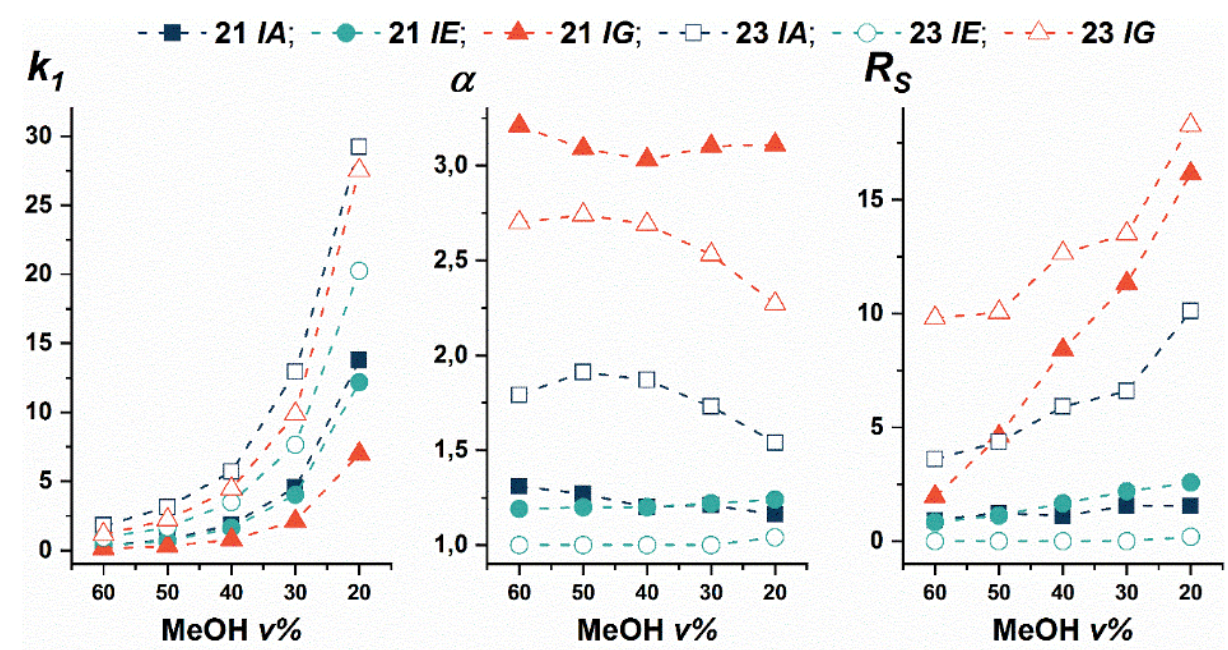

17. ábra SFC eluensösszetétel hatása az elválasztásra poliszacharid alapú állófázisok esetén

Kromatográfiás körülmények: kolonna, $I A, I E, I G$; mozgófázis, $\mathrm{MeOH} / \mathrm{CO}_{2}(60 / 40,50 / 50,40 / 60,30 / 70,80 / 20$ $v / v)$ és DEA $(20 \mathrm{mM})$; áramlási sebesség, $2,0 \mathrm{ml} \mathrm{perc}^{-1}$; detektálás, $215-250 \mathrm{~nm}$; hömérséklet, $40{ }^{\circ} \mathrm{C}$; ellennyomás 150 bar. 
A 17. ábrán látható, hogy a $\mathrm{MeOH}$ tartalom csökkentése minden esetben a retenciós idők növekedéséhez vezetett, vagyis a normál fázishoz hasonló viselkedés tapasztalható.

Ezzel szemben a szelektivitás és a felbontás ettől eltérő módon változott. A legtöbb esetben a $\mathrm{MeOH}$ tartalom csökkenésével a szelektivitás alig változott, míg a 23 anyag esetén az $I A$ és $I G$ kolonnán maximum görbe írja le a változást. Ezzel szemben a felbontás meredeken nőtt mindkét vegyület esetén az $I G$ oszlopon, valamint a $\mathbf{2 3}$ anyag esetén az $I A$ oszlopon. Feltehetőleg a MeOH tartalom csökkenésével elötérbe kerülö H-híd kölcsönhatás és a szelektorok térszerkezetének változása okozza ezt az egyedi kromatográfiás viselkedést. Ezekben az esetekben a normálfázisú mérésekhez képest jelentősen nagyobb felbontás érhető el. A többi esetben a szelektivitás és a felbontás értékek alig változnak. Emellett észrevehető, hogy a 21 vegyület esetén a szelektivitás mindhárom kolonnán hasonló változást mutat, mint a normál fázis esetén: az eluenst széles tartományában változtatva értékük alig változik, és az $I G$ oszlopon jelentősen nagyobb az elválasztás mértéke (13. ábra).

Az amilóz alapú poliszacharid állófázisok közül mindkét vegyület esetén az $I E$ kolonna rendelkezett a legkisebb enantioszelektivitással, ami jelentős eltérést mutat a normál fázisban tapasztaltakhoz képest. Ez alapján kijelenthető, hogy SFC technikát alkalmazva, a vizsgált komponensek esetén a trisz-(3,5-diklórfenil-karbamát) módosított poliszacharid állófázis nem rendelkezik jelentős enantiomerfelismerő-képességgel, függetlenül a vizsgált mozgófázis összetételétől vagy az alkalmazott alkohol anyagi minőségétől.

\subsection{A mozgófázishoz adott ionos módosítók mennyiségének hatása az elválasztásra}

A mozgófázishoz adott savak és bázisok biztosítják az elválasztandó vegyületek és a szelektor állandó értékü ionizáltságát, valamint ioncserélő állófázisok esetén uralkodó szerepet töltenek be az elválasztásban. Ioncserélö állófázisok esetén a kromatográfiás rendszerben található ionok versengenek a szelektor ionos kötőhelyeiért, így az ionos módosítók mennyiségével a vizsgált komponensek retenciós idői hangolhatók [31, 138]. Az eluensben található ionok közül az elválasztandó ionnal azonos töltésűeket ellenionnak nevezzük, az ellentétes töltésűek a kíséröionok. Tehát egy anioncserélő állófázis esetén az eluenshez adott savból származó anionok ellenionoknak tekinthetők, míg az esetleg hozzáadott bázisból származó kationok a kísérő ionok.

Ikerionos állófázis esetén az elválasztandó vegyületek funkciós csoportja határozza meg, hogy mit tekintünk ellen- és mit kísérő ionnak. Amfolit vegyület és ikerionos szelektor esetén az eluenshez adott sav és bázis összetett hatással lehet a szelektor és a vizsgált 
komponens között kialakuló kettős ionpár kölcsönhatásra. Ilyen esetben a rendszerben fellépő ionos kölcsönhatások jellemzéséhez különösen fontos az ellen- és kísérő ionok egyértelmü definiálása.

Az ioncserélő állófázisok esetén a kromatográfiás rendszer jellemzésére leggyakrabban a sztöchiometrikus helyettesítési modellt használják [31, 60, 138-140]. A modell alapja a 13. egyenlet,

$\lg k=\lg K_{Z}-Z \lg$ Cellenion,

ahol $k$ a retenciós tényező, $K_{Z}$ a rendszer állandó, $Z$ az elválasztandó ionok és az ellenionok töltésének aránya (ún. effektív töltés) és $c_{\text {ellenion }}$ az ellenion koncentráció. Ez alapján látható, hogy ha a modell érvényes a kromatográfiás rendszerre, akkor a retenciós tényező logaritmusa az ellenion koncentráció logaritmusának függvényében ábrázolva egyenest ad, amelynek meredeksége az effektív töltéssel arányos.

\subsubsection{A mozgófázishoz adott ellen- és kísérő ionok jelenlétének hatása}

A cinkóna alkaloid alapú ioncserélő állófázisok esetén az eluenshez adott sav és bázis hatásának vizsgálatához a 11 alanil-triptofán amfolit dipeptidet használtam. Az ikerionos kolonnák szelektora egyaránt tartalmaz kation- és anioncserélő funkciós csoportokat, így fennáll a lehetőség, hogy azok ellenionként viselkedve lehetővé tegyék a vizsgált vegyület elúcióját sav vagy bázis hozzáadása nélkül. Az amfolit vegyület esetén mind a kationos, mind az anionos funkciós csoport lehetőséget teremt a szelektorral való kölcsönhatásra. Így az 5.1.1.2. fejezet eredményei alapján az ikerionos $Z W I X(+)$ és $Z W I X(-)$ kolonnákon $\mathrm{MeOH} / \mathrm{MeCN}(50 / 50 v / v)$ összetételü eluenst alkalmazva összehasonlítottam az elválasztási tulajdonságokat, ha az eluens nem tartalmaz ionos módosítót, $25 \mathrm{mM}$ DEA-t, $25 \mathrm{mM}$ FA-t vagy $25 \mathrm{mM}$ DEA-t és $50 \mathrm{mM}$ FA-t tartalmaz (18. és függelék F6 ábra). Irodalmi tapasztalatok alapján, ikerionos állófázisokat használva amfolit vegyületek vizsgálatára, a hozzáadott ionok anyagi minősége csekély eltérést okoz a kromatográfiás rendszer tulajdonságaiban, ezért nem vizsgáltam a hozzáadott sav és bázis anyagi minőségének hatását [31, 92, 141]. 

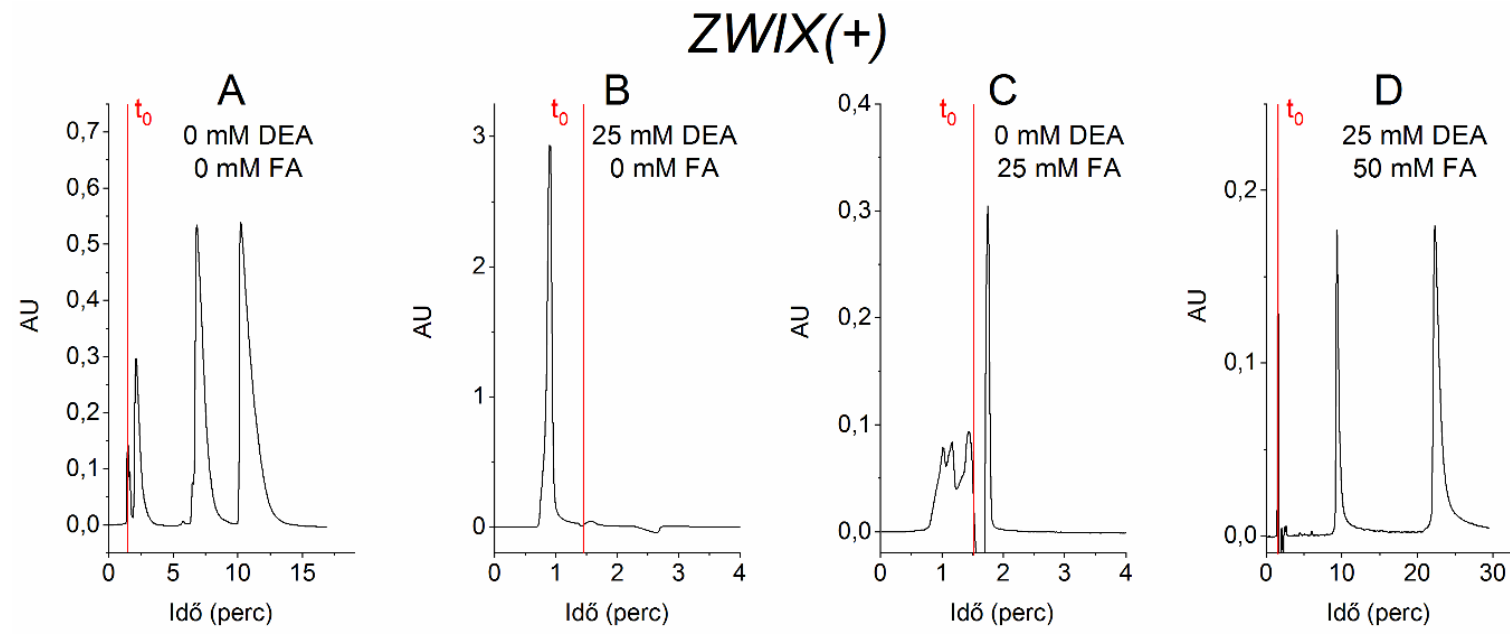

18. ábra A mozgófázishoz adott sav, illetve bázis hatása az elválasztásra

Kromatográfiás körülmények: kolonna, ZWIX(+); mozgófázis, MeOH/MeCN (50/50 v/v) és DEA (0 vagy 25 $\mathrm{mM}$ ) és FA (0 vagy $25 \mathrm{mM}$ vagy $50 \mathrm{mM}$ ); áramlási sebesség, 0,6 ml perc ${ }^{-1}$; detektálás, 221-280 nm; hömérséklet, $25^{\circ} \mathrm{C}$.

A 18. (A) és függelék F6 (A) ábrán látható az elválasztás eredménye, ha az eluens nem tartalmaz ionos módosítót. Ekkor a szelektoron található negatív töltésű szulfonsavcsoport ellenionként viselkedik a dipeptid karboxilcsoportjával szemben, illetve kötőhelyként a részben protonált aminocsoportokat tekintve. Emellett, a szelektor és elválasztandó vegyület, részben protonált aminocsoportjai szintén ellenion szerepet tölthetnek be a királis felismerés folyamata során. Ezért a vizsgált vegyület megkötődhet a szelektoron, így az ionos módosítók hiányában is lehetséges részleges vagy teljes elválasztást elérni. Azonban a hozzáadott sav és/vagy bázis hiányában sem a szelektor, sem az állófázis ellenőrzött (állandó) ionos állapota nem biztosított, így a retenciós idők is mérésről mérésre változnak.

Abban az esetben, ha az eluens csak bázist tartalmaz (18. (B) és függelék F6 (B) ábra), akkor mind a szelektor, mind a vizsgált dipeptid aminocsoportja deprotonált állapotú, így köztük kettős ionpár kölcsönhatás nem alakulhat ki. Emellett a szelektoron található szulfonsavcsoport és a $\mathbf{1 1}$ vegyület karboxilcsoportja egyaránt negatív töltésü, így azok kölcsönös taszítása következtében a $\mathbf{1 1}$ vegyület gyakorlatilag visszatartás nélkül haladt keresztül a kolonnán. Mivel még a holtidőnél is kevesebb idő alatt eluálódott a vizsgált anyag, ezért feltételezhető, hogy a méretkizárásos kromatográfiához hasonlóan, a vizsgált dipeptid nem képes behatolni az állófázis pórusaiba.

Ha az eluens csak savat tartalmaz (18. (C) és függelék F6 (C) ábra), akkor a szelektor és a 11 vegyületen található aminocsoportok protonáltak és pozitív töltésűek. Emellett a szelektor szulfonsavcsoportja és a dipeptid szabad karboxilcsoportja részben protonált. Így 
ez esetben csekély visszatartás figyelhető meg, azonban a pozitív töltésű funkciós csoportok jelentős taszítása nem teszi lehetővé a megfelelő királis felismerést.

Ha az eluens savat és bázist egyaránt tartalmaz (18. (D) és függelék F6 (D) ábra), akkor a szelektor és az amfolit dipeptid között lehetséges a kettős ionpár kölcsönhatás kialakulása. Ennek következtében lehetővé válik a királis felismerés és az enantiomerek sikeres elválasztása. Az ionos módosítót nem tartalmazó méréshez képest látható, hogy az enantiomerek később eluálódtak, valamint az enantioszelektivitás is jelentősen javult, az ilyen körülmények között végzett mérések jól ismételhetők voltak. A sav és bázis arány változtatás hatását korábban több alkalommal vizsgálták [92, 142], és általában a 2:1-hez savfelesleg vezetett a legnagyobb enantioszelektivitáshoz, ezért én is ezt az arányt alkalmaztam.

Ezen eredmények alapján kijelenthető, hogy az ikerionos cinkóna alkaloid alapú állófázisok esetén, az ismételhető enantioszelektív elválasztáshoz nélkülözhetetlen a sav és bázis módosítók egyidejü hozzáadása a mozgófázishoz.

\subsubsection{A mozgófázishoz adott ellen- és kísérő ionok mennyiségének hatása az elválasztásra ikerionos és monoionos állófázisok esetén}

A cinkóna alkaloid alapú állófázisok alkalmazásakor, ha az ionos kölcsönhatások meghatározók az elválasztás során, akkor a mozgófázishoz adott sav és bázis mennyiségével szabályozható a vizsgált komponensek visszatartása. Ez esetben a sztöchiometrikus helyettesítési modellel vizsgálhatók a rendszerben végbemenő folyamatok.

Ezek mélyebb megismeréséhez összehasonlítottam, hogy az azonos alkaloidra épülő ikerionos és monoionos állófázisok esetén a sav és bázis mennyiségének változtatása milyen hatással van az elválasztásra. Állófázisként a kinidin alapú $Z W I X(-)$ és $Q D-A X$, valamint a kinin alapú $Z W I X(+)$ és $Q N-A X$ kolonnákat használtam. Mozgófázisnak, az 5.1.1.2. fejezetben bemutatott eredmények alapján, a $\mathrm{MeOH} / \mathrm{MeCN}(50 / 50 \quad v / v)$ összetételt választottam, melyhez ionos módosítóként hozzáadtam DEA-t 6,25 mM - $100 \mathrm{mM}$ koncentráció tartományban, valamint FA-t 12,5 mM - 200 mM koncentráció tartományban. A hozzáadott sav mennyisége minden esetben kétszerese volt a bázisnak. Vizsgált vegyületként az 5.1.1.2. fejezetben is alkalmazott 2, 6, 9, 11 és 16 dipeptideket választottam. Mivel a vizsgált négy állófázis közül kettő anioncserélő, ezért ellenionként az FA-t és kísérő ionként a DEA-t használtam. Az így kapott eredmények a 19. és függelék F7 ábrán láthatók. 


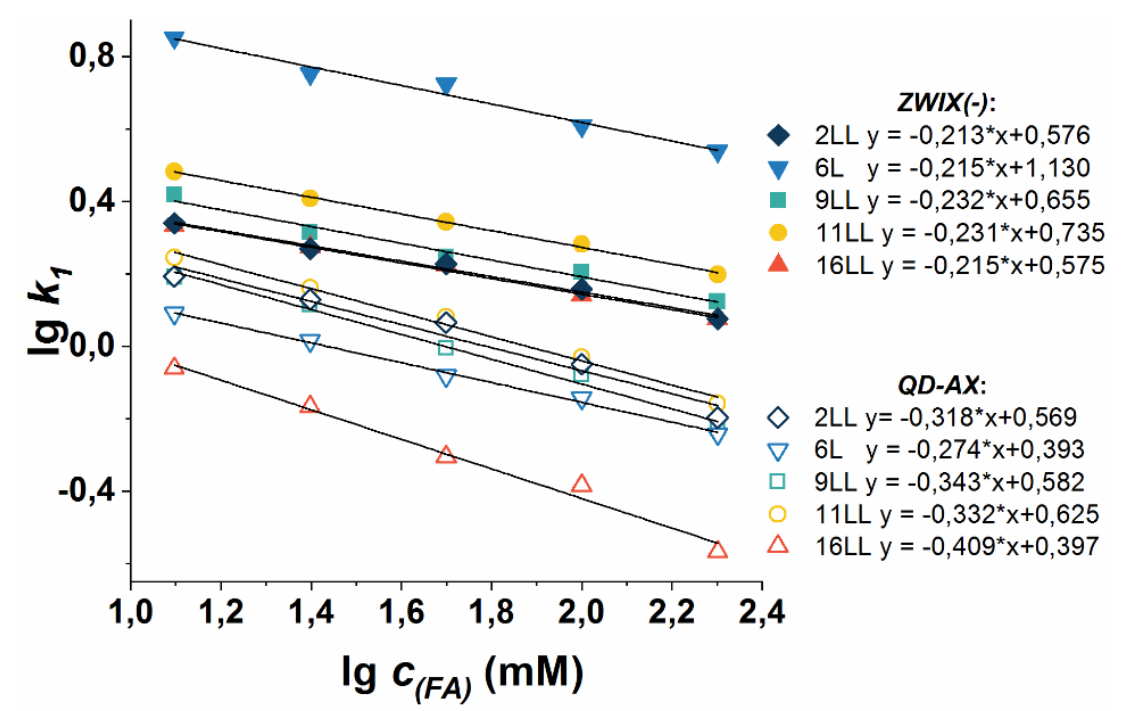

19. ábra Az eluenshez adott sav és bázis mennyiségének hatása az elválasztásra

Kromatográfiás körülmények: kolonna, $Z W I X(-)$ és $Q D-A X$; mozgófázis, MeOH/MeCN $(50 / 50 v / v)$ és DEA/FA $(6,25 / 12,5,12,5 / 25,25 / 50,50 / 100$ és $100 / 200(\mathrm{mM} / \mathrm{mM}))$; áramlási sebesség, 0,6 $\mathrm{ml} \mathrm{perc}{ }^{-1}$; detektálás, $221-280 \mathrm{~nm}$; hömérséklet, $25^{\circ} \mathrm{C}$.

A 19. és függelék F7 ábrán egyaránt megfigyelhető, hogy az ellenion koncentráció növelés hatására a retenciós idők minden esetben csökkentek, ahogy az az ioncserélö állófázisok esetén jellemző. Emellett az is észrevehető, hogy az elsőként eluálódó enantiomer retenciós tényezőjének tízes alapú logaritmusa lineárisan változik az ellenion koncentráció tízes alapú logaritmusával. Így látható, hogy a sztöchiometrikus helyettesítési modell mind a monoionos, mind az ikerionos állófázisok esetén jól leírja a vizsgált vegyületek kromatográfiás viselkedését. Kevés kivételtől eltekintve megfigyelhető, hogy az ábrázolt adatokra illesztett egyenesek meredeksége független a vizsgált vegyületek szerkezetétől. Emellett általánosan igaz, hogy az illesztett egyenesek meredeksége nagyobb negatív értékü monoionos állófázisok esetén, mint az ikerionos szelektorok esetén. Ez a megfigyelés egybevág az irodalomban korábban leírtakkal [31, 141, 142], és bemutatja, hogy az ikerionos állófázisok esetén kevésbé függ a visszatartás az ellenion koncentrációtól, mint monoionos szelektorok esetén.

Továbbá észrevehető, hogy azonos ellenion koncentrációnál, az ikerionos szelektorok esetén mindig nagyobb volt a komponensek visszatartása, mint a megfelelő anioncserélő oszlopok esetén. Ez a különbség a szelektorokon található kötőhelyek számának eltérésével magyarázható. Az ikerionos szelektorok több ionos kölcsönhatás kialakítására képes funkciós csoportot tartalmaznak, mint a monoionos szelektorok, így több ionos kölcsönhatást alakíthatnak ki az amfolit vegyületekkel. Ezért ikerionos szelektorok esetén nagyobb a visszatartás mértéke a monoionosokhoz képest. 
Minden kolonna esetén teljesült a vizsgált vegyületekre, hogy az eluens sav és bázis tartalmának módosítása alig változtatta a szelektivitás és felbontás értékeket. Így megállapítható, hogy a vizsgált koncentráció tartományban a királis felismerés folyamata független a mozgófázisban található sav és bázis koncentrációjától. Ezek alapján, a vizsgált vegyületek és oszlopok esetén teljesül, hogy az enantioszelektivitás számottevő változása nélkül az ellenion koncentráció változtatással szabályozható az elválasztandó komponensek visszatartása.

\subsubsection{Az SFC és HPLC mozgófázishoz adott ellen- és kísérő ionok hatásának összehasonlítása cinkóna alkaloid alapú állófázisok esetén}

Az SFC technika mozgófázisa jelentősen eltérő fizikai és kémiai sajátságokkal jellemezhető, mint a hasonló összetételü HPLC mozgófázis [66, 70]. A két technika mozgófázisának különbözősége jelentősen eltérő kromatográfiás viselkedéshez vezethet. Ez a jelenség jól megfigyelhető az ioncserén alapuló kromatográfiás elválasztások esetén.

Ha az SFC mozgófázis alkoholt tartalmaz, akkor a szubkritikus állapotú folyékony széndioxid alkoxikarbonsav képződéséhez vezető reakcióba lép vele [82]. Így, a HPLC technikával ellentétben, az SFC technika mozgófázisa akkor is tartalmazhat ellenionokat, ha savat nem adtunk a mozgófázishoz. Ennek legfőbb előnye a preparatív kromatográfiában figyelhető meg. Ha nincs elegendő nyomás alatt az eluens, hogy a szén-dioxid folyékony halmazállapotú legyen, akkor az eluensből távozó szén-dioxid hatására a korábban képződött alkoxikarbonsav visszaalakul szén-dioxidra és alkoholra. Így SFC technika esetén lehetséges az ioncserén alapuló kromatográfiás elválasztás anélkül, hogy az elválaszott komponenseket a visszamaradt savas karakterü anyagoktól tisztítani kelljen. Azonban ilyen esetben a retenciós idő nem szabályozható az ellenion koncentráció változtatással, ezért biztosan hosszabb mérési időkre kell számítani, mint sav hozzáadása esetén.

A mozgófázishoz adott ellen- és kísérőionok hatásának további megismerése érdekében összehasonlítottam az SFC és a HPLC technika esetén a mozgófázishoz adott sav és bázis mennyiség változtatásának hatását. Állófázisként az ikerionos $Z W I X(+)$ és $Z W I X(-)$ kolonnákat használtam és a bázikus 17 és az amfolit 18 vegyületeket vizsgáltam. Mozgófázisként, az 5.1.3.1. fejezet eredményei alapján, SFC technika esetén $\mathrm{MeOH} / \mathrm{CO}_{2}$ (30/70 v/v), HPLC technika esetén MeOH/MeCN (30/70 v/v) összetételt használtam. A mozgófázishoz FA-t és DEA-t adtam 2:1-es savfelesleg arányban 7,5/15;15/30; 30/60 és 60/120 (mM/mM) koncentrációkban. Mivel a 17 komponens bázikus kémhatású, ezért 
ellenionként a DEA-t választottam. Az így kapott eredmények a 20. és függelék F8 ábrán láthatók.

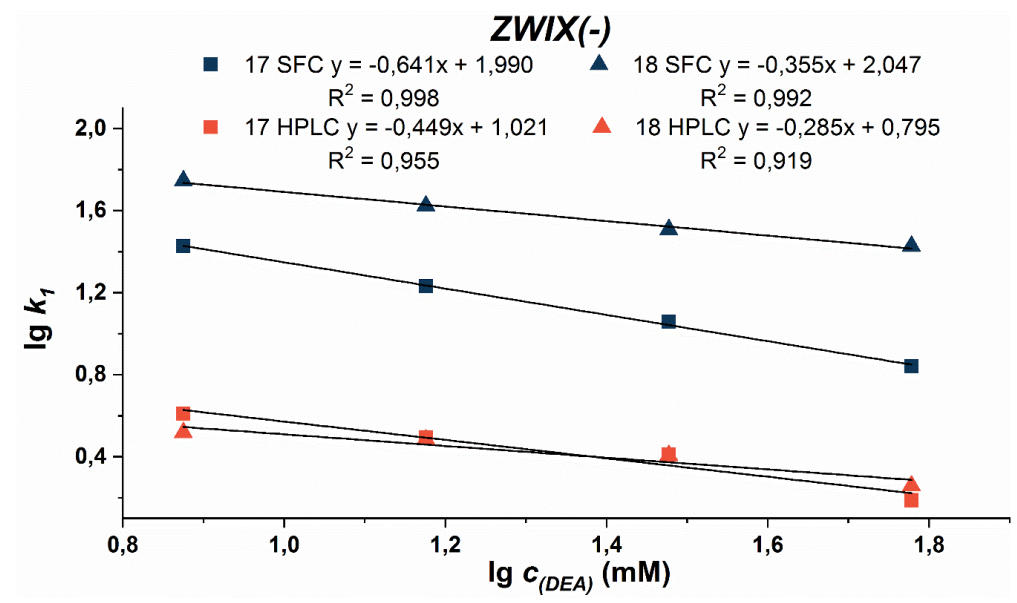

20. ábra Az SFC és a HPLC mozgófázishoz adott sav és bázis hatásának összehasonlítása Kromatográfiás körülmények: kolonna, $Z W I X(-)$; mozgófázis, HPLC esetén $\mathrm{MeOH} / \mathrm{MeCN}(30 / 70 v / v)$ és DEA/FA (7,5/15, 15/30, 30/60 és 60/120 (mM/mM)), SFC esetén MeOH/CO 2 (30/70 v/v) és DEA/FA (7,5/15, 15/30, 30/60 és 60/120 (mM/mM)); áramlási sebesség, HPLC, 0,6 $\mathrm{ml} \mathrm{perc}^{-1}$, SFC, $2 \mathrm{ml} \mathrm{perc}{ }^{-1}$, detektálás, 221$280 \mathrm{~nm}$; hömérséklet, HPLC, $25^{\circ} \mathrm{C}$, SFC $40^{\circ} \mathrm{C}$; ellennyomás 150 bar.

A 20. és függelék F8 ábrán egyaránt megfigyelhető, az 5.2.2. fejezetben leírtakhoz hasonlóan, hogy mindkét vegyület esetén az elsőként eluálódó enantiomer retenciós tényezőjének tízes alapú logaritmusa lineárisan változik az ellenion koncentráció tízes alapú logaritmusával. Vagyis a sztöchiometrikus helyettesítési modell mind az SFC, mind a HPLC technika esetén egyaránt érvényes. Emellett mindkét vizsgált kolonnánál észrevehető, hogy HPLC technika esetén a bázikus és az amfolit molekulák hasonló visszatartással rendelkeznek. Ezzel szemben az SFC technikánál a bázikus 17 vegyület nagyobb visszatartással rendelkezik, mint az amfolit komponens mindkét kolonnán. További hasonlóság az 5.2.2. fejezethez, hogy az ellenion koncentráció növelés hatására a visszatartás minden esetben csökkent, míg a szelektivitás és a felbontás értékek jelentősen nem változtak.

Emellett az is megfigyelhető, hogy a „monoionos” szerkezetü 17 vegyület esetén minden esetben nagyobb negatív értékü a mért adatokra illesztett egyenes meredeksége, mint az amfolit 18 vegyület esetén. Ez alapján, ikerionos szelektorok esetén, az amfolit vegyület visszatartása kevésbé függ a mozgófázis ellenion koncentrációjától, mint az egyféle funkciós csoporttal rendelkező 17 komponens visszatartása. Ennek oka feltehetőleg a 18 vegyületnél kialakuló kettős ionpár kölcsönhatás következtében kialakuló stabilabb megkötődés. A 20. és függelék F8 ábrán látható adatokra illesztett meredekségek hasonlóak az ikerionos kolonnákon korábban mért adatokhoz $[125,131]$. Ez alapján, az ikerionos kolonnákon a lg $k_{1}-\lg c_{\text {ellenion }}$ függvényekre illesztett egyenesek meredeksége abszolútértékben mindig 
nagyobb, ha a szelektor monoionos ioncserélöként funkcionál, mint ha ikerionos módban müködik. A fentiek alapján kijelenthető, hogy ikerionos kolonnáknál, a mozgófázishoz adott sav és bázis mennyiségének változtatására végbemenő kromatográfiás folyamatok jól leírhatók a sztöchiometrikus helyettesítési modellel mind az SFC, mind a HPLC technika esetén.

\subsection{A molekula szerkezet és a kromatográfiás jellemzők összefüggései}

A megfelelö vegyületek rendszerezett kromatográfiás vizsgálatával mélyebb betekintés nyerhető arról, hogy hogyan befolyásolja az elválasztást meghatározó folyamatokat a vizsgált komponensek szerkezete. A biológiai és gyógyszeripari jelentőséggel rendelkező vegyületek kiválóan alkalmasak ilyen összefüggések megismerésére, mert az optimális biológiai hatásért felelős molekulaszerkezet felderítéséhez gyakran számos analóg szerkezetü vegyület létrehozása szükséges. E vegyületek összehasonlító kromatográfiás vizsgálata megmutatja, hogy a molekulaszerkezet változtatás hatására hogyan változnak a retenciós sajátságok, milyen kölcsönhatások felelősek az elválasztásért, valamint mely szelektor a legalkalmasabb az adott vegyületcsalád elválasztására. Így nemcsak a királis szelektorok müködéséről szerezhetők ismeretek, hanem az analitikai gyakorlat számára is hasznosítható tapasztalatok gyüjthetők.

\subsubsection{A cinkóna alkaloid alapú állófázisok szerkezetének hatása az elválasztásra}

A cinkóna alkaloid alapú állófázisok szerkezetének hatását a retenciós sajátságokra 20 biológiailag aktív dipeptid enantiomerpár vizsgálatával határoztam meg. Az 5.1.1-es és az 5.2.2-es fejezet eredményei alapján mozgófázisként a $\mathrm{MeOH} / \mathrm{MeCN}(50 / 50 v / v)$ és a $\mathrm{MeOH} / \mathrm{THF}(70 / 30 v / v)$ mozgófázis összetételt választottam, melyek egyaránt 25 mM DEAt és 50 mM FA-t tartalmaztak. Állófázisként a korábban bemutatott $Z W I X(+), Z W I X(-), Q N-$ $A X$ és $Q D-A X$ kolonnát használtam. Az így kapott eredmények az 5. táblázatban és a függelék F3 és F4 táblázatban láthatók. Mivel a $\mathrm{MeOH} / \mathrm{MeCN}$ és a $\mathrm{MeOH} / \mathrm{THF}$ mozgófázissal kapott eredmények esetén jellemzően hasonló irányú változások figyelhetők meg, ezért kijelenthetö, hogy az MeCN és a THF eluensalkotók cseréje, hasonló elúciós erősségű mozgófázis összetétel esetén, nem befolyásolja érdemben az enantioszelektivitást. 


\begin{tabular}{|c|c|c|c|c|c|c|c|c|}
\hline \multirow[t]{2}{*}{ Vegyület } & $k_{1}$ & $\alpha$ & $R s$ & \multirow{2}{*}{$\begin{array}{l}\text { Elúciós } \\
\text { sorrend }\end{array}$} & $k_{1}$ & $\alpha$ & $\boldsymbol{R} s$ & \multirow{2}{*}{$\begin{array}{l}\text { Elúciós } \\
\text { sorrend }\end{array}$} \\
\hline & \multicolumn{3}{|c|}{$Z W I X(+)$} & & & \multicolumn{2}{|c|}{$Z W I X(-)$} & \\
\hline 1 & 2,60 & 1,03 & 0,29 & $\mathrm{DD}<\mathrm{LL}$ & 1,30 & 1,35 & 1,24 & $\mathrm{LL}<\mathrm{DD}$ \\
\hline 1 & 2,13 & 1,14 & 0,97 & $\mathrm{DL}<\mathrm{LD}$ & 1,26 & 1,03 & 0,21 & $\mathrm{LD}<\mathrm{DL}$ \\
\hline 2 & 2,25 & 1,13 & 0,94 & $\mathrm{DD}<\mathrm{LL}$ & 1,35 & 1,17 & 1,15 & $\mathrm{LL}<\mathrm{DD}$ \\
\hline 3 & 2,24 & 1,09 & 0,90 & $\mathrm{LL}<\mathrm{DD}$ & 1,31 & 1,00 & 0,00 & - \\
\hline 4 & 2,43 & 1,13 & 1,03 & $\mathrm{DD}<\mathrm{LL}$ & 1,79 & 1,12 & 0,80 & $\mathrm{LL}<\mathrm{DD}$ \\
\hline 4 & 1,91 & 1,12 & 0,53 & $\mathrm{DL}<\mathrm{LD}$ & 2,47 & 1,17 & 1,29 & $\mathrm{LD}<\mathrm{DL}$ \\
\hline 5 & 2,47 & 1,00 & 0,00 & - & 1,36 & 1,20 & 0,90 & $\mathrm{LL}<\mathrm{DD}$ \\
\hline 6 & 4,41 & 1,45 & 4,36 & $\mathrm{D}<\mathrm{L}$ & 3,73 & 1,34 & 2,50 & $\mathrm{~L}<\mathrm{D}$ \\
\hline 7 & 0,10 & 1,00 & 0,00 & - & 0,10 & 1,00 & 0,00 & - \\
\hline 8 & 1,55 & 1,00 & 0,00 & - & 1,01 & 1,12 & 0,55 & $\mathrm{LL}<\mathrm{DD}$ \\
\hline 9 & 2,37 & 1,21 & 1,52 & $\mathrm{DD}<\mathrm{LL}$ & 1,44 & 1,42 & 1,30 & $\mathrm{LL}<\mathrm{DD}$ \\
\hline 10 & 2,64 & 1,28 & 1,96 & $\mathrm{DD}<\mathrm{LL}$ & 1,72 & 1,46 & 2,00 & $\mathrm{LL}<\mathrm{DD}$ \\
\hline 11 & 3,43 & 2,21 & 7,09 & $\mathrm{DD}<\mathrm{LL}$ & 1,73 & 1,96 & 3,50 & $\mathrm{LL}<\mathrm{DD}$ \\
\hline 12 & 3,16 & 1,00 & 0,00 & - & 1,36 & 1,19 & 0,53 & $\mathrm{~L}<\mathrm{D}$ \\
\hline 13 & 2,74 & 1,33 & 3,21 & $\mathrm{D}<\mathrm{L}$ & 2,37 & 1,26 & 2,00 & $\mathrm{~L}<\mathrm{D}$ \\
\hline 14 & 2,90 & 1,55 & 2,55 & $\mathrm{DD}<\mathrm{LL}$ & 2,65 & 1,40 & 2,94 & $\mathrm{LL}<\mathrm{DD}$ \\
\hline 14 & 2,31 & 1,44 & 2,71 & $\mathrm{DL}<\mathrm{LD}$ & 1,96 & 1,17 & 0,97 & $\mathrm{LD}<\mathrm{DL}$ \\
\hline 15 & 1,86 & 1,28 & 1,95 & $\mathrm{DD}<\mathrm{LL}$ & 2,53 & 1,12 & 0,94 & $\mathrm{LL}<\mathrm{DD}$ \\
\hline 16 & 2,67 & 1,15 & 1,40 & $\mathrm{DD}<\mathrm{LL}$ & 1,23 & 1,17 & 0,63 & $\mathrm{LL}<\mathrm{DD}$ \\
\hline 16 & 1,50 & 1,24 & 1,77 & $\mathrm{DL}<\mathrm{LD}$ & 0,72 & 1,16 & 0,53 & $\mathrm{DL}<\mathrm{LD}$ \\
\hline \multicolumn{5}{|c|}{$Q N-A X$} & \multicolumn{4}{|c|}{$Q D-A X$} \\
\hline 1 & 0,60 & 1,00 & 0,00 & - & 0,60 & 1,75 & 1,07 & $\mathrm{LL}<\mathrm{DD}$ \\
\hline 1 & 0,49 & 1,00 & 0,00 & - & 0,63 & 1,00 & 0,00 & - \\
\hline 2 & 0,91 & 1,46 & 2,35 & $\mathrm{DD}<\mathrm{LL}$ & 1,08 & 1,52 & 2,44 & $\mathrm{LL}<\mathrm{DD}$ \\
\hline 3 & 0,25 & 1,00 & 0,00 & - & 0,48 & 1,00 & 0,00 & - \\
\hline 4 & 0,96 & 1,25 & 1,82 & $\mathrm{DD}<\mathrm{LL}$ & 0,96 & 1,40 & 2,43 & $\mathrm{LL}<\mathrm{DD}$ \\
\hline 4 & 0,76 & 1,00 & 0,00 & - & 1,00 & 1,00 & 0,00 & - \\
\hline 5 & 0,98 & 1,00 & 0,00 & - & 0,95 & 1,30 & 1,56 & $\mathrm{LL}<\mathrm{DD}$ \\
\hline 6 & 0,70 & 1,00 & 0,00 & - & 0,95 & 1,15 & 1,05 & $\mathrm{~L}<\mathrm{D}$ \\
\hline 7 & $*$ & - & - & - & $*$ & - & - & - \\
\hline 8 & $*$ & - & - & - & $*$ & - & - & - \\
\hline 9 & 1,00 & 1,34 & 2,36 & $\mathrm{DD}<\mathrm{LL}$ & 0,88 & 1,48 & 2,47 & $\mathrm{LL}<\mathrm{DD}$ \\
\hline 10 & 1,26 & 1,25 & 1,88 & $\mathrm{DD}<\mathrm{LL}$ & 1,63 & 1,09 & 0,82 & $\mathrm{LL}<\mathrm{DD}$ \\
\hline 11 & 1,01 & 1,51 & 2,36 & $\mathrm{DD}<\mathrm{LL}$ & 1,12 & 1,58 & 2,35 & $\mathrm{LL}<\mathrm{DD}$ \\
\hline 12 & 1,01 & 1,00 & 0,00 & - & 0,90 & 1,49 & 1,89 & $\mathrm{~L}<\mathrm{D}$ \\
\hline 13 & 1,08 & 1,14 & 0,63 & $\mathrm{D}<\mathrm{L}$ & 0,93 & 1,28 & 1,52 & $\mathrm{~L}<\mathrm{D}$ \\
\hline 14 & 1,02 & 1,52 & 4,36 & $\mathrm{DD}<\mathrm{LL}$ & 0,99 & 2,01 & 4,73 & $\mathrm{LL}<\mathrm{DD}$ \\
\hline 14 & 2,58 & 1,00 & 0,00 & - & 2,01 & 1,00 & 0,00 & - \\
\hline 15 & 0,41 & 1,00 & 0,00 & - & 0,54 & 1,71 & 2,14 & $\mathrm{LL}<\mathrm{DD}$ \\
\hline 16 & 0,48 & 2,19 & 3,20 & $\mathrm{DD}<\mathrm{LL}$ & 0,55 & 2,37 & 4,00 & $\mathrm{LL}<\mathrm{DD}$ \\
\hline 16 & 0,39 & 1,00 & 0,00 & - & 0,54 & 1,00 & 0,00 & - \\
\hline
\end{tabular}

5. táblázat $\mathrm{A}$ vizsgált dipeptidek kromatográfiás paraméterei cinkóna alkaloid alapú állófázisokon $\mathrm{MeOH} / \mathrm{MeCN}$ eluens esetén

Kromatográfiás körülmények: kolonna, $Z W I X(+), Z W I X(-), Q N-A X$ és $Q D-A X$; mozgófázis, $\mathrm{MeOH} / \mathrm{MeCN}$ $(50 / 50 v / v)$ és DEA $(25 \mathrm{mM})$ és FA $(50 \mathrm{mM})$; áramlási sebesség, $0,6 \mathrm{ml}$ perc $^{-1}$; detektálás, 221-280 nm; hőmérséklet, $25^{\circ} \mathrm{C}$; * holtidő elötti elúció. 
Az alábbiakban összefoglalom a szelektor szerkezete és a vizsgált dipeptidek retenciós viselkedése közötti legfontosabb összefüggéseket.

- Az 1, 4, 14 és 16 dipeptideket tekintve a homokirális (LL, DD) enantiomerek jellemzően nagyobb visszatartást és enantioszelektivitást tapasztaltam, mint a heterokirális (LD, DL) sztereoizomerek esetén.

- A 2, 4 és 5 dipeptidek szerkezete a $C$-terminális mellett található oldallánc hosszúságában különbözik, sorrendjük a lánchossz alapján: $2<\mathbf{4}<\mathbf{5}$. Az azonos szerkezetü oldallánc hosszának növekedésével az anioncserélő oszlopokon minden esetben csökkent a szelektivitás és a felbontás. Ikerionos oszlopok esetén ilyen egyértelmü tendencia nem figyelhető meg, ami arra utal, hogy a kationcserélő funkciós csoporttal kialakuló kölcsönhatások képesek ellensúlyozni az enantioszelektivitás csökkenését.

- Összehasonlítva az egyetlen metiléncsoportban különböző 2 és 3 vegyület kromatográfiás adatait látható, hogy minden esetben kisebb a $\mathbf{3}$ vegyület visszatartása, valamint a ZWIX(+) kolonnát kivéve, megszünt az enantioszelektivitás. A metiléncsoport „,beillesztésének” hatására a 3 vegyület esetén megváltozott a szén-szén kötés körül a szabad rotáció. Így a kiralitáscentrum és a szelektorral erős ionos kölcsönhatást kialakító karboxilcsoport közötti távolság növekedése, illetve a szerkezeti merevség csökkenése a királis felismerés elvesztéséhez vezetett.

- Összevetve a 4, 7 és 8 dipeptidek kromatográfiás sajátságait, kijelenthető, hogy a vizsgált vegyületek karboxilcsoportja jelentős hatással van az enantiomerek megkülönböztetési folyamatára. A 4 vegyület karboxilcsoportjának metilészterré alakítása a 7-es, míg a karboxilcsoport amidálása a 8 vegyülethez vezet. A 7 vegyületet egyik kolonna sem volt képes elválasztani, míg az ikerionos szelektorok a $\mathbf{8}$ vegyület esetén rendelkeztek némi enantioszelektivitással. Emellett a szabad karboxilcsoport hiányában a $\mathbf{7}$ és $\mathbf{8}$ vegyületek visszatartása gyakorlatilag minimálisra csökkent, anioncserélő szelektor esetén még a holtidőnél is hamarabb eluálódtak. Ezt feltehetőleg a szelektor és a peptid protonált aminocsoportjai között fellépő taszítás okozta.

- A 4 és a 14 dipeptidet azonos aminosavak alkotják, azonban azok sorrendje a molekulán belül ellentétes. A 14 vegyület $N$-terminálisa közelében található aromás gyürü szinte minden esetben nagyobb visszatartást eredményezett, mint a 4 vegyület esetében. A retenciót befolyásoló hatás mellett az is megfigyelhetö, hogy a 14 vegyület jellemzően nagyobb szelektivitással és felbontással vált el, mint a 4 vegyület. Ezért megállapítható, 
hogy a dipeptidet felépítő aminosavak sorrendje jelentős hatással van a királis felismerésre.

- Az aromás oldallánc hatására az 1, 4 és a 11 vegyületek kromatográfiás sajátságainak összehasonlításával világíthatunk rá. Az 1 vegyület aromás gyürüt nem tartalmaz, a 4 vegyület egy fenilcsoportot, míg a 11 vegyület egy kondenzált gyürüs indolt tartalmaz. Így a vizsgált komponensekben az $N$-terminálist alkotó aminosav megegyezik, míg a $C$ terminális aminosavon az aromás jelleg az $1<\mathbf{4}<\mathbf{1 1}$ sorrendben növekszik. Ez a trend szinte minden esetben illik a vegyületek szelektivitásának és felbontásának növekedési sorrendjére. Emellett az is megfigyelhetö, hogy a legnagyobb visszatartással minden esetben a 11 vegyület rendelkezik. Ezeknek az eredményeknek az lehet a magyarázata, hogy az aromás oldallánc révén $\pi$ - $\pi$ és H-híd kölcsönhatások alakulhatnak ki a szelektor és az elválasztandó enantiomerek között, melyek jó hatással vannak a királis felismerésre. Az itt megfigyelt változásokat alátámasztják az aromás aminosavak viselkedéséről szerzett korábbi ismeretek [143]. Ezek alapján kijelenthetö, hogy az aromás oldallánc jelenléte és az aromás gyürü tagszámának növelése cinkóna alkaloid alapú állófázisok esetén elősegíti a királis felismerést.

- A dipeptidek $C$-terminálisa közelében található aromás csoportok módosítása szintén jelentős hatással lehet az elválasztásra. A 4 vegyület fenilcsoportjához para helyzetben hidroxilcsoportot kötve a 9, míg nitrocsoportot kötve a $\mathbf{1 0}$ dipeptid jön létre. Áttekintve ikerionos szelektorok esetén az adatokat, az elválasztás jelentős javulása figyelhető meg 4<9< 10 sorrendben. A hidroxilcsoport H-híd kötéseket hozhat létre, a nitrocsoport pedig $\pi$-savas karakterü, így az aromás kinolin rendszerrel $\pi$ - $\pi$ kölcsönhatásokat alakíthat ki, ami jelentősen segítheti a királis felismerést. Anioncserélő szelektorok esetén a kromatográfiás adatok jellemzően kevésbé különböztek ezeknél a vegyületeknél, így egyértelmű irányú változás nem állapítható meg.

- Ha egy peptid valamelyik aminosavát akirális glicin aminosavra cserélik, akkor a királis centrumok számának csökkenése mellett a királis felismerést befolyásoló sztérikus gátlás mértéke is csökken, mivel a glicin nem tartalmaz oldalláncot [144, 145]. Ennek a cserének a hatása vizsgálható a 4 (alanil-fenilalanin) és a 12 (glicil-fenilalanin), illetve a $\mathbf{1 4}$ (fenilalanil-alanin) és a $\mathbf{1 3}$ (fenilalanil-glicin) vegyületek esetén. Az akirális aminosav beépítésének hatására mindkét esetben jelentősen csökkent az elválasztás mértéke.

Ezzel szemben, ikerionos kolonnák esetén, a 4 és a 6 ( $\beta$-alanil-fenilalanin) vegyület elválasztási sajátságainak összehasonlításakor ellentétes tendencia figyelhető meg. A 6 vegyület oldallánc nélküli $\beta$-alanilt tartalmaz az $N$-terminálison, melynek hatására mind 
a visszatartás, mind a felbontás jelentősen nőtt. Vagyis ikerionos szelektorok esetén, a dipeptid $N$-terminálisának környezete jelentősen javíthatja az enantioszelektivitást, függetlenül attól, hogy kiralitás centrum található-e a közelében. Anioncserélő oszlop esetén a dipeptid $N$-terminális aminosav és a szelektor között nem alakul ki vonzó kölcsönhatás, így feltehetőleg sztérikus hatások miatt, a kiralitás centrum hiánya csökkenti a szelektivitást.

Áttekintve az azonos mozgófázis összetétellel mért adatokat, megállapítható, hogy a kinin alapú $Z W I X(+)$ és $Q N-A X$ állófázisok esetén az 1-11 dipeptideket tekintve a $k_{1}$ jellemzően nagyobb, míg a szelektivitás és a felbontás általában kisebb volt, mint a kinidin alapú $Z W I X(-)$ és $Q D-A X$ kolonnák esetén. Emellett fontos megemlíteni, hogy a heterokirális 1 és 14, valamint a homokirális 3 és 16 dipeptideket kivéve, a szabad karboxilcsoportot tartalmazó vegyületeket sikeresen el lehet választani az anioncserélő kolonnákon is.

A függelék F4 táblázata alapján összehasonlítva az oszlophatékonyságot jellemző elméleti tányérszámra vonatkozó adatokat látható, hogy azonos mozgófázis összetétel esetén, az ikerionos állófázisoknak szinte kivétel nélkül nagyobb a hatékonysága, mint a monoionos állófázisoknak, ami jellemzően nagyobb enantioszelektivitást eredményezett. Ezt az eltérést feltehetőleg az ikerionos szelektor esetén fellépő kettős ionpárképződés, sztérikus hatások és H-kötések együttes hatása okozza.

A vizsgált kinin és kinidin alapú állófázisok gyakran jellemezhetők pszeudoenantiomer viselkedéssel. Ezt a jelenséget a tanulmányozott dipeptideknél is igazoltam. A kinin alapú állófázisok esetén szinte mindig az $N$-terminális közelében $\mathrm{D}$ konfigurációjú királis centrumot tartalmazó enantiomer eluálódott elöször, ezzel szemben kinidin-alapú szelektorok esetén az ellentétes konfigurációjú enantiomernek volt kisebb visszatartása. E szabálytól eltérően viselkedett a 3 vegyület $Z W I X(+)$ és a heterokirális 16 vegyület a $Z W I X(-)$ oszlopon $\mathrm{MeOH} / \mathrm{MeCN}$ mozgófázis esetén, illetve a heterokirális $\mathbf{4}$ vegyület anioncserélő oszlopokon $\mathrm{MeOH} / \mathrm{THF}$ mozgófázis alkalmazásakor. A $\mathrm{MeOH} / \mathrm{MeCN}$ és a $\mathrm{MeOH} / \mathrm{THF}$ mozgófázis rendszerek cseréje nem változtatta meg az enantiomerek elúciós sorrendjét. Függetlenül attól, hogy monoionos vagy ikerionos az alkalmazott állófázis, a vizsgált dipeptidek enantiomer sorrendje nem változott az azonos cinkóna alkaloid alapú szelektorok esetén. Mivel a monoionos szelektorok csak a dipeptidek szabad karboxilcsoportjával képesek erős vonzó kölcsönhatást kialakítani, ezért kijelenthető, hogy a $C$-terminális közelében lévő királis szénatom konfigurációja meghatározó az enantiomer sorrend kialakulásánál. 
Az 1, 4, 14 és 16 dipeptidekből mind a négy lehetséges enantiomer rendelkezésemre állt, így a 4 diasztereomer elválasztásával a szelektorok diasztereoszelektivitása is összehasonlítható volt. Ez esetben megfigyelhető, hogy a cinkóna alkaloid alapú állófázisok diasztereomer vegyületek elválasztására való használatára kevésbé volt hatékony a THF tartalmú mozgófázis alkalmazása. $\mathrm{MeOH} / \mathrm{MeCN}$ eluensrendszerrel $Z W I X(+)$ állófázison az 1, 14 és 16, míg $Z W I X(-)$ állófázison az 1, 4, 14 dipeptideket sikerült diasztereoszelektíven elválasztani. Ehhez képest a MeOH/THF eluensrendszerrel a $Z W I X(+)$ állófázison az 1, 4, 16, míg $Z W I X(-)$ állófázison a $\mathbf{1 6}$ dipeptid enantiomerei váltak el. Az anioncserélő állófázisokkal a diasztereomereket nem lehetett egymástól elválasztani. A diasztereomerek sikeres elválasztását bemutató néhány kromatogram a 21. ábrán látható. Ezek a példák jól illusztrálják a cinkóna alkaloid alapú állófázisok sokoldalú használhatóságát.
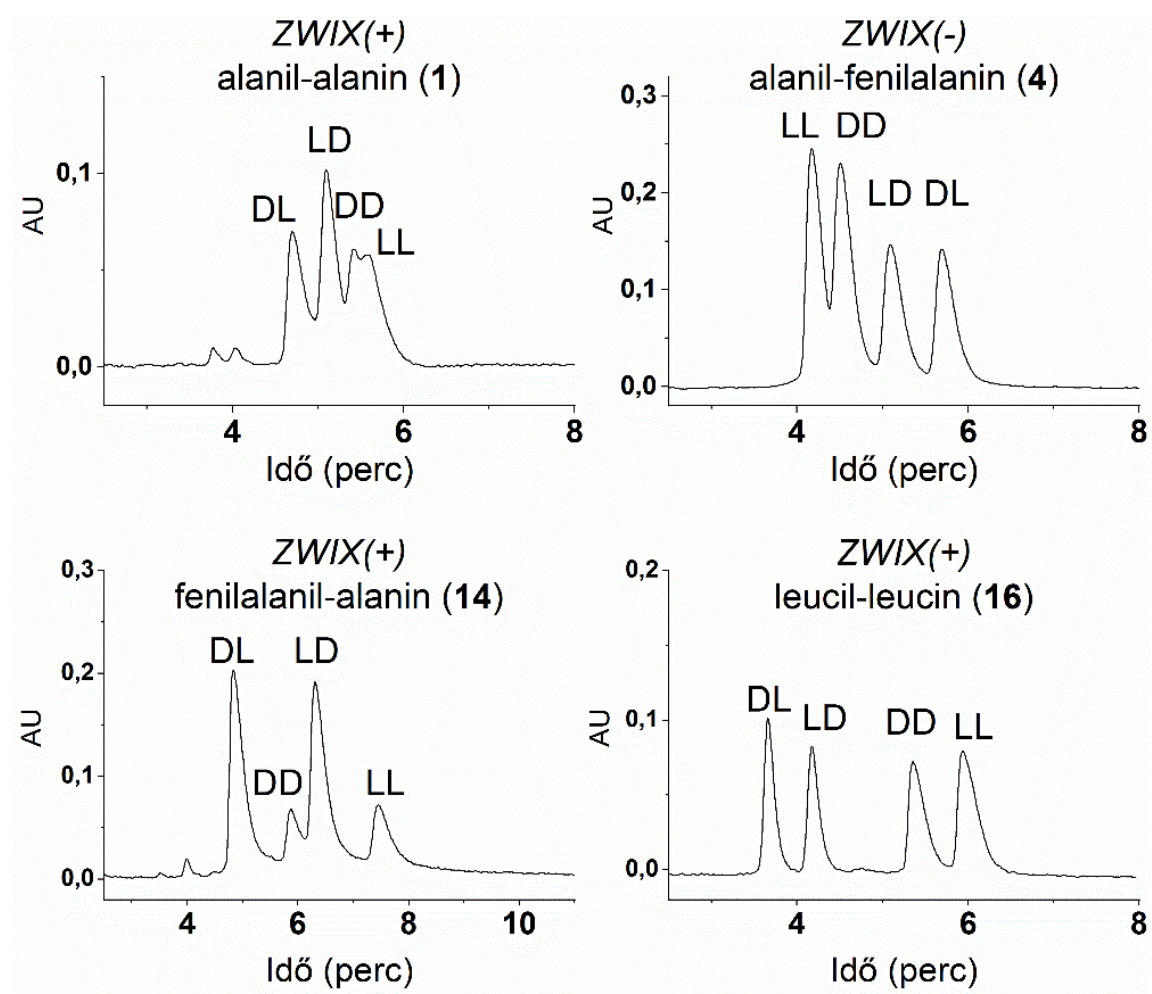

21. ábra Az ikerionos szelektorok enantio- és diasztereoszelektív elválasztóképessége Kromatográfiás körülmények: kolonna, $Z W I X(+)$, és $Z W I X(-)$; mozgófázis, MeOH/MeCN (50/50 v/v) és DEA $(25 \mathrm{mM})$ és FA ( $50 \mathrm{mM}$ ); áramlási sebesség, $0,6 \mathrm{ml} \mathrm{perc}{ }^{-1}$; detektálás, $221-280 \mathrm{~nm}$; hőmérséklet, $25^{\circ} \mathrm{C}$.

\subsubsection{A poliszacharid alapú állófázisok szerkezete és a kromatográfiás viselkedés összefüggése}

A poliszacharid alapú állófázisok szerkezete és a vizsgált vegyületek retenciós sajátságai közötti kapcsolat felderítése érdekében normál fázisú mozgófázist alkalmazva azonos körülmények között megvizsgáltam a 17-31 vegyületek elválasztási tulajdonságait. Állófázisként az $I A, I B, I C, I D, I E, I F$ és $I G$ kolonnákat használtam, mozgófázisként pedig az 5.1.2. fejezet eredményei alapján $n$-hexán/2-PrOH $(80 / 20 v / v)$ és $\operatorname{DEA}(0,1 \quad v \%)$ 
mozgófázis rendszert. A 24 és $\mathbf{2 5}$ vegyületek esetén a megfelelő visszatartás érdekében csökkentettem az eluenserősséget, ezért e komponensek elválasztásához $n$-hexán/2-PrOH $(98 / 2 v / v)$ és DEA $(0,1 v \%)$ mozgófázist használtam. Az így kapott eredmények a 6. táblázatban láthatók. Mivel a jelentősen polárisabb, karboxilcsoportot tartalmazó 18, 20 és 22 vegyületek nem rendelkeztek visszatartással normál fázisú mozgófázis esetén, ezért e vegyületek adatait a 6. táblázat nem tartalmazza.

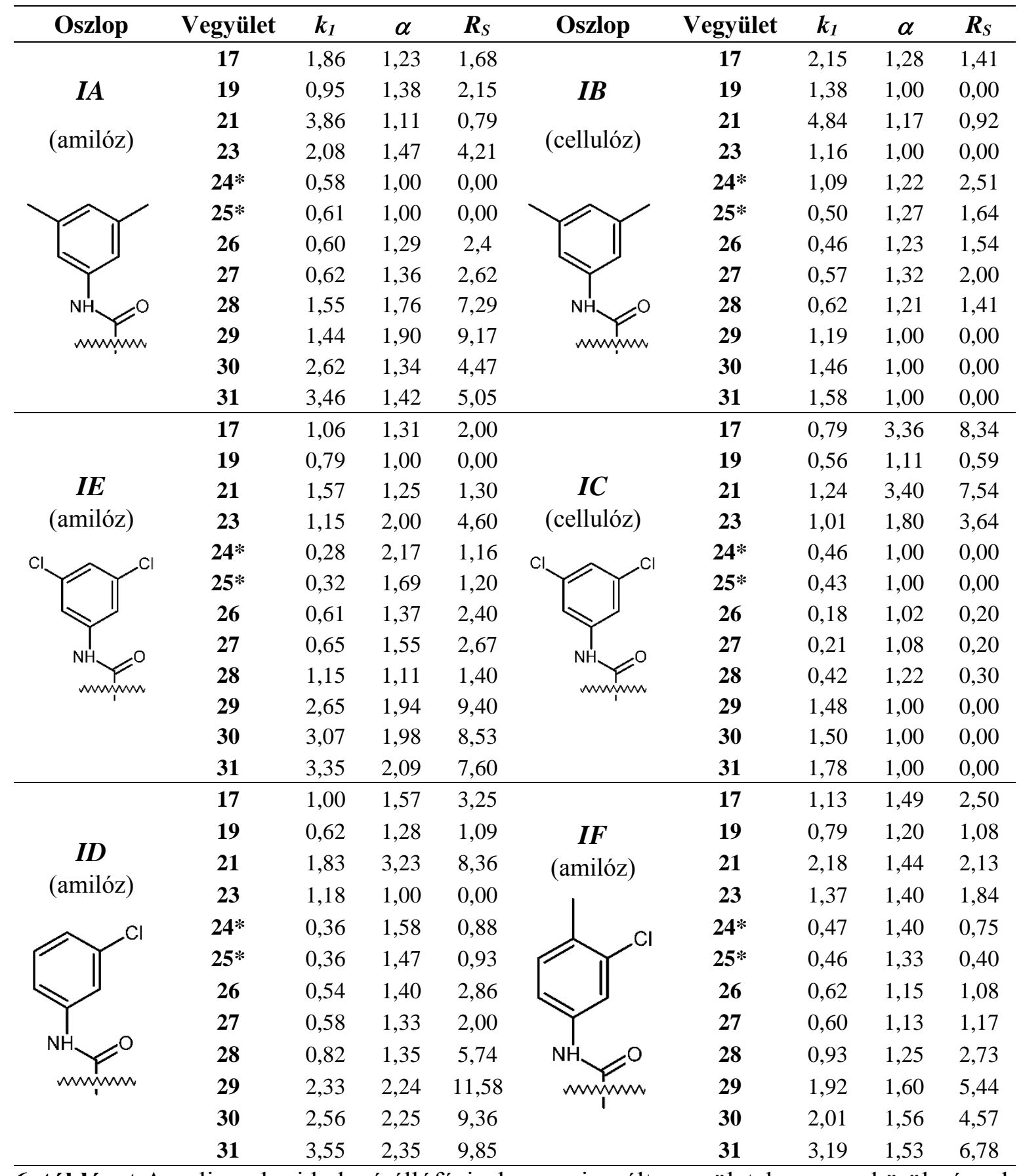

6. táblázat $A$ poliszacharid alapú állófázisokon a vizsgált vegyületek azonos körülmények között mért kromatográfiás adatai

Kromatográfiás körülmények: kolonna, $I A, I B, I C, I D, I E, I F, I G$; mozgófázis, $n$-hexán/2-PrOH $(80 / 20 v / v)$ és DEA $(0,1 v \%)$ vagy * $n$-hexán/2-PrOH $(98 / 2 v / v)$ és DEA $(0,1 v \%)$; áramlási sebesség, $1,0 \mathrm{ml}$ perc $^{-1}$; detektálás, 215-250 nm; hőmérséklet, szobahőmérséklet. 


\begin{tabular}{ccccc}
\hline Oszlop & Vegyület & $\boldsymbol{k}_{\boldsymbol{I}}$ & $\boldsymbol{\alpha}$ & $\boldsymbol{R}_{\boldsymbol{S}}$ \\
\hline & $\mathbf{1 7}$ & 1,46 & 1,37 & 2,44 \\
& $\mathbf{1 9}$ & 0,80 & 1,47 & 2,67 \\
$\mathbf{I G}$ & $\mathbf{2 1}$ & 2,65 & 1,45 & 2,63 \\
(amilóz) & $\mathbf{2 3}$ & 1,40 & 2,02 & 7,58 \\
& $\mathbf{2 4}$ & 0,60 & 1,22 & 1,03 \\
& $\mathbf{2 5 *}$ & 1,00 & 1,00 & 0,00 \\
& $\mathbf{2 6}$ & 0,76 & 1,80 & 4,67 \\
& $\mathbf{2 7}$ & 0,78 & 1,64 & 3,65 \\
& $\mathbf{2 8}$ & 0,90 & 1,25 & 1,65 \\
& $\mathbf{2 9}$ & 2,97 & 1,11 & 1,62 \\
& $\mathbf{3 0}$ & 3,41 & 1,60 & 6,75 \\
& $\mathbf{3 1}$ & 3,67 & 1,55 & 6,52 \\
\hline
\end{tabular}

6. táblázat (folytatás) A poliszacharid alapú állófázisokon a vizsgált vegyületek azonos körülmények között mért kromatográfiás adatai

Kromatográfiás körülmények: kolonna, $I A, I B, I C, I D, I E, I F, I G$; mozgófázis, $n$-hexán/2-PrOH $(80 / 20 v / v)$ és DEA $(0,1 v \%)$ vagy * $n$-hexán/2-PrOH $(98 / 2 v / v)$ és DEA $(0,1 v \%)$; áramlási sebesség, $1,0 \mathrm{ml}$ perc $^{-1}$; detektálás, 215-250 nm; hömérséklet, szobahőmérséklet.

A 17, 19 és 21 vegyületek kromatográfiás adatait összehasonlítva, a legkisebb visszatartást és enantioszelektivitást jellemzően a 19 vegyület esetén tapasztaltam. Vagyis a szelektor szerkezetétől függetlenül a 19 vegyület benzazepin gyürüje illeszkedett legkevésbé a vizsgált polimerláncokhoz. Ezt a megfigyelést támasztja alá a 24 és 25 vegyület retenciós viselkedése is. Mindkét anyag benzazepin gyürüt tartalmaz, és csak a jelentősen kevesebb alkoholt tartalmazó eluens esetén figyelhető meg visszatartás, illetve királis felismerés.

A 26 és 27, illetve 28 vegyületek összehasonlításával a klór, valamint a H-híd kialakítására képes metoxicsoport hatása vizsgálható. A funkciós csoportok hozzáadásának hatására az enantioszelektivitás jellemzően növekedett, vagy csak keveset változott. Ez alól kivételt képez az IG oszlop, ahol csökkenés figyelhető meg. A 29 és 30, illetve 31 vegyületek esetén egyértelmủen leírható változás a szelektivitásban nem tapasztalható.

Egybevetve a 26 és 29, 27 és 30, valamint a 28 és 31 vegyületek retenciós sajátságait, megfigyelhető a dimetoxicsoport hozzáadásának elválasztásra gyakorolt hatása. Amennyiben sikeres volt az elválasztás, a dimetoxicsoport hatására jellemzően jelentősen növekedett a szelektivitás és a felbontás. Ez alapján a H-híd kölcsönhatások kialakítására képes csoportok számának növelése a vizsgált vegyületeken fokozhatja a poliszacharid alapú állófázisok enantiomerfelismerő-képességét.

Összevetve az azonos poliszacharid alapú, de eltérően módosított szelektorokat, megfigyelhető a módosító szubsztituensek hatása. A trisz-(3,5-dimetilfenil-karbamát)-ot 
tartalmazó $I A$ és $I B$ oszlopon kapott eredményeket a trisz-(3,5-diklórfenil-karbamát)-ot tartalmazó $I E$ és $I C$ kolonnákon meghatározott adatokkal összevetve, a metilcsoportokat tartalmazó kolonnákon volt nagyobb a visszatartás. Ezzel szemben az enantioszelektivitás általában a klórt tartalmazó kolonnákon volt jelentősebb.

$\mathrm{Az}$ is megfigyelhető, hogy az azonos módosítót tartalmazó amilóz és cellulóz alapú szelektorok ( $I A$ és $I B$, illetve $I E$ és $I C$ ) összehasonlítása esetén a 17, 19 és 21 vegyületekre nézve jellemzően a cellulóz alapú állófázisok nyújtottak nagyobb enantioszelektivitást, míg a 23-31 vegyületek esetén az amilóz alapú szelektorok voltak hatékonyabbak. A poliszacharid lánc térszerkezetének elválasztásra gyakorolt kimagasló hatása is megfigyelhető az amilóz alapú $I E$ és a cellulóz alapú $I C$ kolonnák összehasonlításával. Az IC kolonnán a 24-31 vegyületek nem, vagy csak kis mértékben válnak el, míg az IE kolonnán kimagasló $\left(R_{S}>9\right)$ elválasztás is megfigyelhető. Vagyis a szelektort alkotó poliszacharid és annak módosító szubsztituensei egyaránt jelentős hatással vannak az elválasztandó vegyületek kromatográfiás viselkedésére.

Mind a hét vizsgált állófázison kapott kromatográfiás adatokat áttekintve megállapítható, hogy a 17, 19 és 21 vegyületek esetén jellemzően a klór szubsztituenst tartalmazó szelektorok biztosították a legnagyobb enantioszelektivitást. Így a klór atomok okozta $\pi-\pi$ és H-híd kölcsönhatás változások, a szakirodalommal összhangban [146], feltehetőleg elősegítik a királis felismerés folyamatát. A 6. táblázat adatai alapján, számos esetben az $I E$ oszlop volt a leghatékonyabb állófázis, azonban minden olyan vegyületet, melyet az $I E$ oszlopon nem sikerült jelentős mértékben elválasztani, más kolonnát használva sikerült hatékonyan elválasztani.

A vizsgált komponensek szerkezete mellett a molekula térfogata is hatással lehet a szelektorral való kölcsönhatásra. Ezt bizonyítja a 26-31 vegyületek, melyek térfogatát a Marvin Sketch v. 17.28-as programmal számoltam ki, majd azt a hozzájuk tartozó elsőként eluálódó enantiomer retenciós tényezőjének függvényében ábrázoltam (22. ábra).

A 26, 27 és 28, illetve a 29, 30 és 31 anyagok mindössze egy klór vagy egy metoxi funkciós csoporttal térnek el egymástól. A 22. ábrán jól megfigyelhető, hogy az azonos alapvázú molekulák térfogatának növekedésével minden állófázison nőtt a visszatartás mértéke. Feltehetőleg a méretnövekedés hatására a vizsgált molekulák hatékonyabban illeszkednek a poliszacharid lánchoz, ez okozza a visszatartás növekedést. Mivel minden állófázison azonos tendencia tapasztalható, így kijelenthető, hogy a visszatartás növekedés és a molekulaméret között kapcsolat van. 

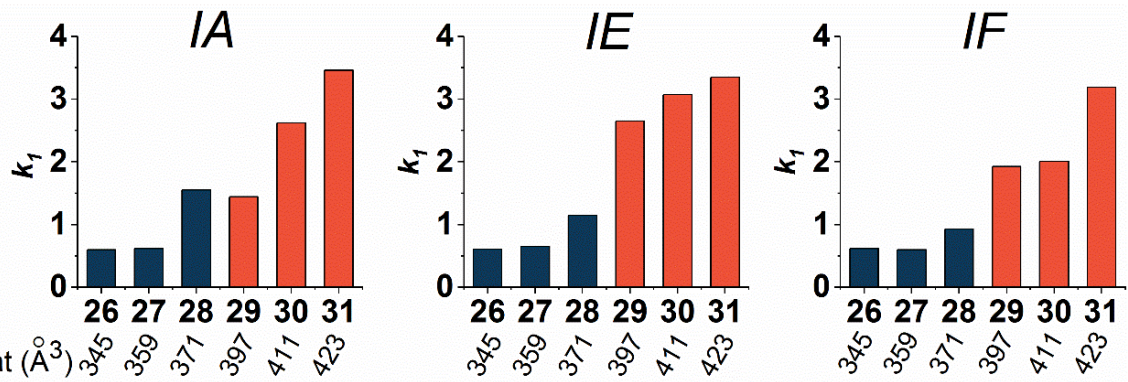

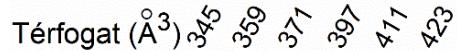
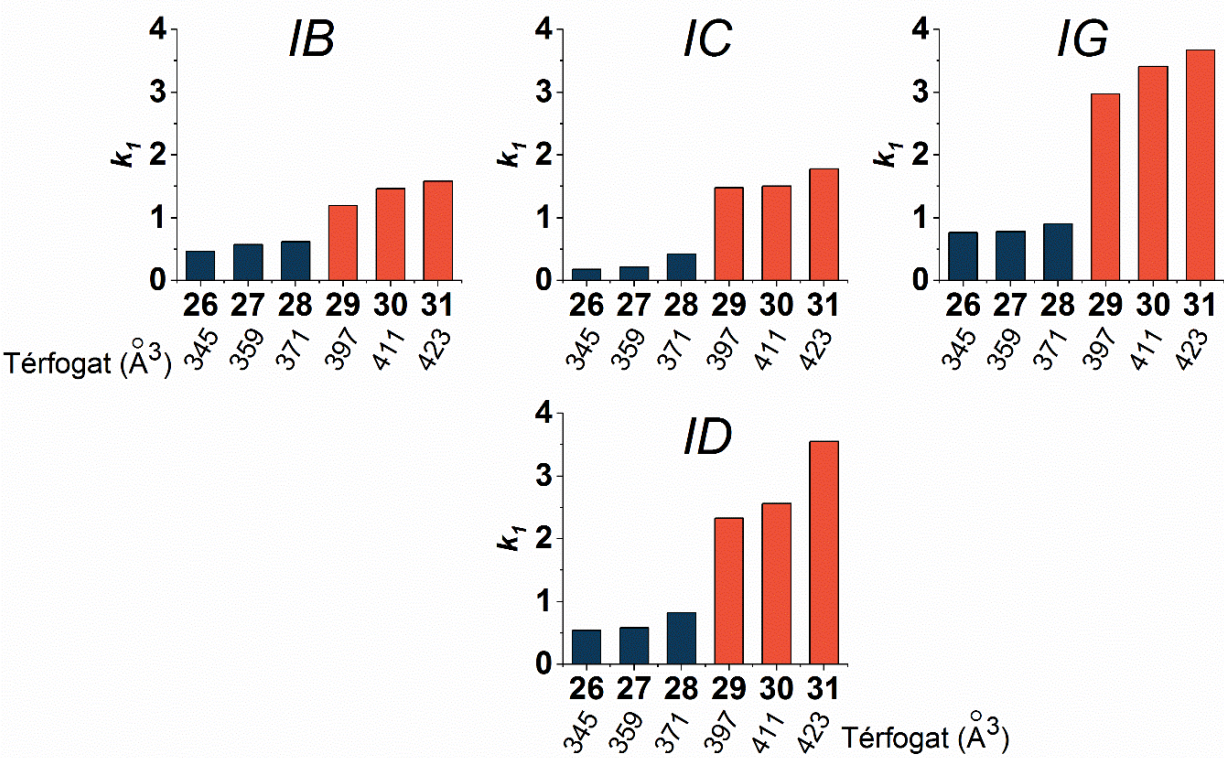

22. ábra A molekulatérfogat és az elsőként eluálódó enantiomer retenciós tényezőjének kapcsolata

Kromatográfiás körülmények: kolonna, $I A, I B, I C, I D, I E, I F$ és $I G$; mozgófázis, $n$-hexán/2-PrOH $(80 / 20 v / v)$ és DEA (0,1 v\%); áramlási sebesség, $1,0 \mathrm{ml}_{\text {perc }}{ }^{-1}$; detektálás, 215-250 nm; hömérséklet, szobahőmérséklet.

5.3.3. A királis szelektorok szerkezete és a kromatográfiás paraméterek összefüggése SFC technika esetén

\subsubsection{Az SFC és HPLC technika összehasonlítása cinkóna alkaloid alapú állófázisok alkalmazásával}

Az SFC technika alkalmazásakor számos tényező hatással lehet a királis állófázison kialakuló kölcsönhatásokra, illetve a szelektor szerkezetének megváltozására. Ezért a királis szelektorok müködésének további megismerése céljából összehasonlítottam a cinkóna alkaloid alapú állófázisok kromatográfiás viselkedését a 17-22 bázikus és amfolit indol analógok elválasztásával HPLC és SFC technikát használva. Állófázisként a $Z W I X(+)$ és $Z W I X(-)$ kolonnát, mozgófázisként a 5.1.3. és 5.2.3. fejezetben bemutatott eredmények alapján, HPLC esetén MeOH/MeCN $(30 / 70 v / v)$ és DEA (30 mM) és FA (60 mM), SFC esetén $\mathrm{MeOH} / \mathrm{CO}_{2}(30 / 70 v / v)$ és DEA (30 mM) és FA (60 mM) összetételt használtam. Az így kapott eredményeket a 7. táblázat foglalja össze. 


\begin{tabular}{cccc|ccc}
\hline \multirow{2}{*}{ Vegyület } & \multicolumn{3}{c|}{ HPLC } & \multicolumn{3}{c}{$\boldsymbol{S} \boldsymbol{C}$} \\
& $\boldsymbol{k}_{\boldsymbol{I}}$ & $\boldsymbol{\alpha}$ & $\boldsymbol{R}_{\boldsymbol{S}}$ & $\boldsymbol{k}_{\boldsymbol{I}}$ & $\boldsymbol{\alpha}$ & $\boldsymbol{R}_{\boldsymbol{S}}$ \\
\hline $\mathbf{7}$ & 1,58 & 1,00 & 0,00 & 11,44 & 1,29 & 4,58 \\
$\mathbf{1 8}$ & 2,57 & 1,56 & 5,36 & 32,23 & 1,46 & 7,41 \\
$\mathbf{1 9}$ & 1,33 & 1,00 & 0,00 & 8,59 & 1,00 & 0,00 \\
$\mathbf{2 0}$ & 3,95 & 1,22 & 2,93 & 27,69 & 1,22 & 3,94 \\
$\mathbf{2 1}$ & 2,50 & 1,11 & 1,03 & 48,62 & 3,29 & 4,79 \\
$\mathbf{2 2}$ & 4,27 & 1,31 & 3,88 & 90,49 & 1,16 & 3,03 \\
\hline \multicolumn{7}{c}{$\boldsymbol{Z W I X ( + )}$} \\
$\mathbf{1 7}$ & 2,59 & 1,05 & 0,63 & 15,41 & 1,00 & 0,00 \\
$\mathbf{1 8}$ & 2,82 & 1,85 & 6,63 & 31,97 & 1,65 & 10,09 \\
$\mathbf{1 9}$ & 1,95 & 1,00 & 0,00 & 12,19 & 1,00 & 0,00 \\
$\mathbf{2 0}$ & 3,51 & 1,11 & 1,82 & 22,91 & 1,05 & 0,99 \\
$\mathbf{2 1}$ & 3,40 & 1,00 & 0,00 & 46,08 & 1,00 & 0,00 \\
$\mathbf{2 2}$ & 4,32 & 1,53 & 4,84 & 88,21 & 1,36 & 6,08 \\
\hline
\end{tabular}

7. táblázat $\mathrm{A}$ cinkóna alkaloid alapú állófázisok elválasztási tulajdonságainak összehasonlítása SFC és a HPC technika alkalmazása esetén

Kromatográfiás körülmények: kolonna, ZWIX(+) és ZWIX(-); mozgófázis, HPLC esetén, MeOH/MeCN (30/70 $v / v)$ és DEA (30 mM) és FA (60 mM), SFC esetén, $\mathrm{MeOH} / \mathrm{CO}_{2}(30 / 70 v / v)$ és DEA (30 mM) és FA (60 mM); áramlási sebesség, HPLC esetén, 0,6 $\mathrm{ml} \mathrm{perc}^{-1}$, SFC esetén 2,0 $\mathrm{ml}_{\text {perc }}{ }^{-1}$; detektálás, 215-250 nm; hőmérséklet, HPLC esetén szobahőmérséklet, SFC esetén $40^{\circ} \mathrm{C}$; SFC ellennyomás 150 bar.

A 7. táblázat adatai alapján látható, hogy SFC technika alkalmazása esetén általában egy nagyságrenddel nagyobbak a retenciós tényezők, mint a HPLC technika esetén, ami az ionos kölcsönhatások felerősödésére utal. Ezt az elképzelést támasztja alá a karboxilcsoportot tartalmazó vegyületek jelentős visszatartása, melyek a szelektor szerkezetétől függetlenül minden esetben kiemelkedően nagy értékek. Azonban fontos megjegyezni, hogy a két eluensrendszer eluenserősségét nehéz közvetlenül összehasonlítani. A bázikus és amfolit vegyületek visszatartásbeli különbsége igazolja a kettős ionpár kölcsönhatás kialakulását. A kiugróan nagy visszatartás ellenére a szelektivitás és a felbontás értékek jelentősen nem térnek el SFC és HPLC technika esetén. Ez arra utal, hogy a királis felismerést meghatározó kölcsönhatások cinkóna alkaloid alapú állófázisok esetén függetlenek az alkalmazott technikától. A bázikus vegyületekkel ellentétben az amfolit vegyületeket minden esetben sikerült elválasztani, így megállapítható, hogy az ikerionos szelektorok hatékonyságát jelentősen segíti, ha a kiindulási vegyület karboxilcsoportot tartalmaz.

Összehasonlítva a $Z W I X(+)$ és $Z W I X(-)$ kolonna adatait, látható, hogy a $Z W I X(+)$ kolonnán jellemzően a HPLC technika okozott nagyobb visszatartást, míg SFC technika esetén, a $Z W I X(-)$ kolonna alakított ki erösebb kölcsönhatást a vizsgált vegyületekkel. A szelektivitást és felbontást tekintve a két állófázis hasonló hatékonysággal müködött. 
A 7. táblázat eredményei alapján megállapítható, hogy a cinkóna alkaloid alapú állófázisok monoionos és ikerionos módban, SFC és HPLC technikával egyaránt használhatók, így kiválóan alkalmasak az ionos vegyületek széleskörü elválasztásra.

\subsubsection{A poliszacharid alapú állófázisok vizsgálata SFC technika alkalmazásával}

A poliszacharid alapú állófázisok vizsgálatához azonos körülmények között elválasztottam a 17-31 vegyületeket hét darab poliszacharid alapú királis kolonnán. Az elválasztáshoz az 5.1.3. fejezetben bemutatott adatok alapján, a $\mathrm{MeOH} / \mathrm{CO}_{2}(50 / 50 v / v)$ és DEA (20 mM) eluensösszetételt és az $I A, I B, I C, I D, I E, I F$ és $I G$ állófázisokat használtam. Az így kapott eredményeket a 8. táblázat mutatja be. A 8. táblázat SFC adatainak elemzéséhez számos esetben a HPLC technikával kapott 6. táblázat eredményeivel hasonlítom őket össze. Az így összehasonlított adatok azonos állófázisok és vegyületek felhasználásával, de jelentősen eltérő mozgófázisokkal készültek. Ez esetben nem a konkrét kromatográfiás adatok közvetlen egybevetése a célom, hanem a két eltérő technika esetén megfigyelt kromatográfiás adatok változásának felderítése és a változást okozó kölcsönhatások megismerése. 


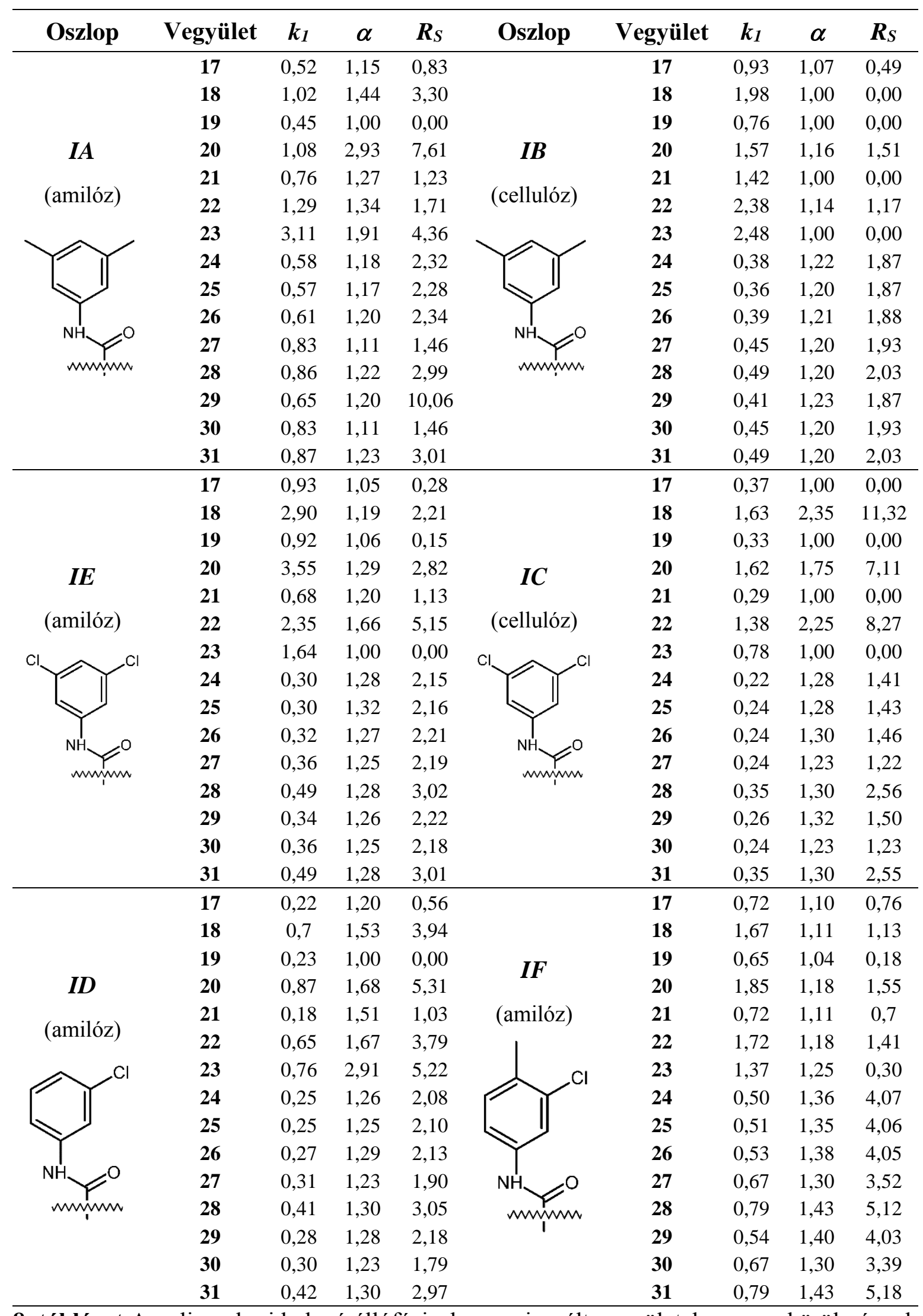

8. táblázat A poliszacharid alapú állófázisokon a vizsgált vegyületek azonos körülmények között mért kromatográfiás adatai

Kromatográfiás körülmények: kolonna, $I A, I B, I C, I D, I E, I F, I G$; mozgófázis, $\mathrm{MeOH} / \mathrm{CO}_{2}(50 / 50 v / v)$ és DEA (20 mM); áramlási sebesség, $2,0 \mathrm{ml} \mathrm{perc}{ }^{-1}$; detektálás, $215-250 \mathrm{~nm}$; hömérséklet, $40^{\circ} \mathrm{C}$; ellennyomás 150 bar. 


\begin{tabular}{ccccc}
\hline Oszlop & Vegyület & $\boldsymbol{k}_{\boldsymbol{I}}$ & $\boldsymbol{\alpha}$ & $\boldsymbol{R}_{\boldsymbol{S}}$ \\
\hline & $\mathbf{1 7}$ & 0,33 & 1,51 & 1,71 \\
& $\mathbf{1 8}$ & 1,05 & 3,60 & 12,63 \\
& $\mathbf{1 9}$ & 0,38 & 1,39 & 0,79 \\
$\mathbf{I G}$ & $\mathbf{2 0}$ & 1,21 & 1,00 & 0,00 \\
(amilóz) & $\mathbf{2 1}$ & 0,29 & 3,09 & 4,60 \\
& $\mathbf{2 2}$ & 1,00 & 4,05 & 8,79 \\
& $\mathbf{2 3}$ & 2,20 & 2,74 & 10,06 \\
& $\mathbf{2 4}$ & 0,92 & 1,46 & 4,71 \\
& $\mathbf{2 5}$ & 0,88 & 1,40 & 6,19 \\
& $\mathbf{2 6}$ & 0,92 & 1,46 & 6,22 \\
& $\mathbf{2 7}$ & 1,08 & 1,36 & 5,16 \\
& $\mathbf{2 8}$ & 1,39 & 1,58 & 6,71 \\
& $\mathbf{2 9}$ & 0,95 & 1,50 & 6,11 \\
& $\mathbf{3 0}$ & 1,08 & 1,36 & 5,15 \\
& $\mathbf{3 1}$ & 1,38 & 1,59 & 2,47 \\
\hline
\end{tabular}

8. táblázat (folytatás) A poliszacharid alapú állófázisokon a vizsgált vegyületek azonos körülmények között mért kromatográfiás adatai

Kromatográfiás körülmények: kolonna, $I A, I B, I C, I D, I E, I F, I G$; mozgófázis, $\mathrm{MeOH} / \mathrm{CO}_{2}(50 / 50 v / v)$ és DEA (20 mM); áramlási sebesség, $2,0 \mathrm{ml} \mathrm{perc}^{-1}$; detektálás, $215-250 \mathrm{~nm}$; hömérséklet, $40^{\circ} \mathrm{C}$; ellennyomás 150 bar.

A bázikus és amfolit 17 és 18, 19 és 20, 21 és 22 vegyületek SFC-s adatait összehasonlítva megfigyelhetö, hogy a karboxilcsoport hatására a $k_{l}$ értékek gyakorlatilag minden esetben legalább duplájára nőttek. Az amfolit vegyületek általában nagyobb szelektivitással és felbontással rendelkeztek, mint a megfelelő bázikus analógjuk. Ez jelentős eltérés a HPLCvel kapott eredményektől, mivel normál fázisú körülmények között az amfolit 18, 20 és 22 vegyületek nem rendelkeztek visszatartással. Tehát az SFC-vel való elválasztás során, az eltérő mérési körülmények függvényében, jelentősen különböző mértékü hatással rendelkeznek a visszatartást és enantioszelektivitást okozó kölcsönhatások.

Az eltérő kromatográfiás sajátságok egyik oka lehet az SFC esetén in situ képződő alkoxikarbonsav jelenléte az eluensben [82, 83], illetve a szelektor felszínén feltételezhetően kialakuló alkohol felhalmozódás és polaritásváltozás [79].

A 23-31 anyagok eredményeit összehasonlítva, a 23 vegyület kivételével, csekély visszatartás jellemző $\left(0,22<k_{l}<1,39\right)$. A $\mathbf{2 4 - 3 1}$ vegyületek szelektivitása szük tartományban változott $(1,00-1,59)$ és nem mutatott közvetlen kapcsolatot a molekulaszerkezettel. A kiterjedt aromás rendszerrel jellemezhető $\beta$-karbolint tartalmazó $\mathbf{2 3}$ vegyület esetén a 24-31 vegyületekhez képest kiemelkedő visszatartás és szelektivitás figyelhető meg, amit feltehetőleg sztérikus hatások, illetve H-híd és $\pi$ - $\pi$ kölcsönhatások eredményeznek. 
A 26-31 anyagok molekulatérfogata és visszatartásuk kapcsolata SFC technika esetén a függelék F9 ábrán látható. A függelék F9 ábrán is megfigyelhető a HPLC-nél tapasztalt eredmény (22. ábra), vagyis azonos alapváz esetén a térfogattal párhuzamosan nő a visszatartás. Azonban az SFC technika esetén a retenciós tényezők sokkal szűkebb tartományban változnak, így ennek minden kétséget kizáró igazolásához további mérések szükségesek.

Az $I A$ és $I B$, illetve az $I E$ és $I C$ szelektorokkal kapott adatok összehasonlításával az amilóz és a cellulóz alapváz hatása vizsgálható. A 17-22 anyagokat tekintve a dimetil módosítót tartalmazó szelektorok esetén az amilóz alapú IA kolonna egyértelműen nagyobb enantioszelektivitást biztosít, mint az $I B$, míg az $I E$ és $I C$ kolonna hasonló hatékonysággal választotta el az enantiomereket. A 23-31 vegyületeket vizsgálva jellemzően az amilóz alapú szelektorok okoztak nagyobb szelektivitást és felbontást, közülük az $I G$ kolonna emelhetö ki.

Emellett megfigyelhető, hogy azonos alapvázú, de különböző funkciós csoporttal módosított szelektorokat összehasonlítva ( $I A$ és $I E$, illetve $I B$ és $I C$ ), nincs jelentős különbség az állófázisok enantioszelektivitásában.

Áttekintve a hét szelektoron SFC-vel kapott kromatográfiás adatokat, jellemzően a klór szubsztituenst tartalmazó kolonnák biztosították a legnagyobb felbontást. Mivel a klór atomok hatására az aromás gyürün csökken az elektronsürüség, illetve a H-híd kölcsönhatásokat is befolyásolhatja [146], így megállapítható, hogy a HPLC technikához hasonlóan, az SFC esetén is nagy hatással vannak a királis felismerésre a H-híd és $\pi$ - $\pi$ kölcsönhatások. Összességében az SFC technika több esetben eredményezett sikeres elválasztást, mint a HPLC, azonban a HPLC technika révén is számos esetben alapvonalra történő elválasztás volt elérhető.

A vizsgált poliszacharid alapú állófázisok SFC módban használva kiváló enantiomerfelismerő-képességgel rendelkeztek és még olyan anyagok esetén is sikeres elválasztáshoz vezettek, amelyek normál fázisú körülmények között nem rendelkeztek visszatartással. Így megállapítható, hogy a módosított poliszacharid alapú kolonnák HPLC és SFC technika esetén egyaránt használhatók. Emellett az is kijelenthető, hogy az eltérö módban való használatuk esetén a királis felismerést okozó kölcsönhatások különbözhetnek. Így poliszacharid alapú szelektorok esetén egyik technika sem helyettesítheti minden esetben a másikat, hanem inkább egymást kiegészítő használatuk biztosítja a sikeres enantiomer elválasztás lehetőségét. 


\subsection{A hőmérséklet hatása a királis kromatográfiás rendszerekre}

\subsubsection{A hőmérséklet hatása az elválasztásra cinkóna alkaloid alapú állófázisok esetén}

A királis felismerés termodinamikai hátterének megismerése érdekében négy cinkóna alkaloid alapú állófázison tanulmányoztam dipeptid vegyületek kromatográfiás sajátságainak változását a hőmérséklet függvényében. A $Z W I X(+), Z W I X(-), Q N-A X$ és $Q D$ $A X$ állófázisokon $\mathrm{MeOH} / \mathrm{MeCN}(50 / 50 v / v)$ és DEA $(25 \mathrm{mM})$ és FA $(50 \mathrm{mM})$, illetve $\mathrm{MeOH} / \mathrm{THF}(70 / 30 v / v)$ és DEA (25 mM) és FA (50 mM) mozgófázis rendszerekkel a 2, 6 , 9, 11 és 16 dipeptideket $5-50^{\circ} \mathrm{C}$ tartományban tanulmányoztam.

Az elválasztásokat jellemző kromatográfiás értékek a függelék F5-F8 táblázatokban találhatók. A van’t Hoff egyenlet alapján, a függelék F5-F8 táblázatok adataiból, a szelektivitás természetes alapú logaritmus adatait a hőmérséklet reciprokának függvényében ábrázoltam és a kapott adatsorra illesztett egyenes értékeiből kiszámoltam az elválasztás látszólagos termodinamikai értékeit. Ezek az eredmények a 9. táblázatban és a függelék F9 táblázatban láthatók. A 9. és függelék F9 táblázatok eredményei látszólagos termodinamikai adatokat tartalmaznak, mivel a kiszámításuk alapját képező kromatográfiás paraméterek enantioszelektiv és nem enantioszelektív kölcsönhatások együttes hatásából erednek.

A függelék F5-F8 táblázatok adatai alapján a hőmérséklet növelésének hatására, a mozgófázistól függetlenül, $Z W I X(+)$ kolonnán minden esetben a $k_{1}$ és a szelektivitás is csökkent, míg a többi állófázist tekintve jellemzően a $k_{l}$ nőtt és a szelektivitás csökkent. Ezek alapján a $Z W I X(+)$ kolonna esetén I-es típusú, míg a többi állófázis esetén többnyire III-as típusú kromatográfiás viselkedés figyelhető meg. Emellett látható, hogy a felbontás értékek is szinte kivétel nélkül csökkentek a hömérséklet növekedésével, ami a termodinamikai hatás növekvő jelentőségére utal. Kivételként említhető a ZWIX(-) oszlopon a 11 vegyület, ami esetén a felbontás maximum görbe szerint változik mindkét eluens alkalmazásakor. Ez a viselkedés ritka, de nem példa nélküli [147], és azzal magyarázható, hogy alacsony hőmérsékleten az anyagátadási folyamatok lassulnak, így feltehetőleg kisebb az oszlop hatékonysága, míg magasabb hőmérsékleten a csökkenő szelektivitás vezet kisebb felbontáshoz. Mivel a vizsgált anyagok általában azonos módon viselkedtek a hőmérsékletváltoztatás hatására, ezért feltehetőleg a szelektor térszerkezete határozza meg a kromatográfiás viselkedést. Ezt támasztja alá az is, hogy a $\mathrm{MeOH} / \mathrm{MeCN}$ és $\mathrm{MeOH} / \mathrm{THF}$ mozgófázis rendszerek szinte azonos retenciós viselkedést mutattak a hőmérsékletváltoztatás függvényében. 


\begin{tabular}{|c|c|c|c|c|c|c|}
\hline Vegyület & $\begin{array}{l}-\Delta\left(\Delta \mathbf{H}^{\mathbf{0}}\right) \\
(\mathbf{k J} / \mathbf{m o l})\end{array}$ & $\begin{array}{c}-\Delta\left(\Delta \mathbf{S}^{\mathbf{o}}\right) \\
\left(\mathbf{J} /\left(\mathbf{m o l}^{*} \mathbf{K}\right)\right.\end{array}$ & $\begin{array}{c}\text { Korrelációs } \\
\text { koeffíciens } \\
\left(R^{2}\right)\end{array}$ & $\begin{array}{c}-\mathbf{T} x \Delta\left(\Delta \mathbf{S}^{0}\right)_{298 K} \\
\quad(\mathbf{k J} / \mathbf{m o l})\end{array}$ & $\begin{array}{c}-\Delta\left(\Delta \mathbf{G}^{\mathbf{0}}\right) 298 \mathrm{~K} \\
(\mathbf{k J} / \mathbf{m o l})\end{array}$ & $Q$ \\
\hline \multicolumn{7}{|c|}{$Z W I X(+)$} \\
\hline 2 & 0,6 & 1,1 & 0,995 & 0,3 & 0,3 & 1,8 \\
\hline 6 & 2,6 & 5,7 & 0,998 & 1,7 & 0,9 & 1,5 \\
\hline 9 & 1,1 & 2,0 & 0,993 & 0,6 & 0,5 & 1,8 \\
\hline 11 & 5,4 & 11,7 & 0,999 & 3,5 & 1,9 & 1,5 \\
\hline 16 & 0,6 & 0,7 & 0,960 & 0,2 & 0,4 & 2,9 \\
\hline \multicolumn{7}{|c|}{ ZWIX(-) } \\
\hline 2 & 1,6 & 3,7 & 0,991 & 1,1 & 0,5 & 1,5 \\
\hline 6 & 2,0 & 3,6 & 0,999 & 1,1 & 0,9 & 1,9 \\
\hline 9 & 2,5 & 5,4 & 0,993 & 1,6 & 0,9 & 1,6 \\
\hline 11 & 4,3 & 8,8 & 0,997 & 2,6 & 1,7 & 1,6 \\
\hline 16 & 0,9 & 1,6 & 0,990 & 0,5 & 0,4 & 1,9 \\
\hline \multicolumn{7}{|c|}{$Q N-A X$} \\
\hline 2 & 2,9 & 6,6 & 0,959 & 2,0 & 0,9 & 1,5 \\
\hline $6^{*}$ & 3,6 & 6,8 & 0,997 & 2,0 & 1,6 & 1,8 \\
\hline 9 & 7,2 & 22,1 & 0,969 & 6,6 & 0,6 & 1,1 \\
\hline 11 & 7,1 & 20,7 & 0,988 & 6,2 & 0,9 & 1,1 \\
\hline 16 & 14,6 & 42,9 & 0,978 & 12,8 & 1,8 & 1,1 \\
\hline \multicolumn{7}{|c|}{$Q D-A X$} \\
\hline 2 & 4,9 & 13,0 & 0,997 & 3,9 & 1,0 & 1,3 \\
\hline 6 & 2,1 & 5,6 & 0,994 & 1,7 & 0,4 & 1,2 \\
\hline 9 & 4,2 & 10,9 & 0,991 & 3,2 & 1,0 & 1,3 \\
\hline 11 & 6,5 & 17,8 & 0,993 & 5,3 & 1,2 & 1,2 \\
\hline 16 & 7,8 & 18,0 & 0,994 & 5,3 & 2,5 & 1,5 \\
\hline
\end{tabular}

9. táblázat Termodinamikai adatok cinkóna alkaloid alapú állófázisok és $\mathrm{MeOH} / \mathrm{MeCN}$ mozgófázisrendszer alkalmazása esetén

Kromatográfiás körülmények: kolonna, ZWIX(+), ZWIX(-), $Q N-A X$ és $Q D-A X$; mozgófázis, MeOH/MeCN $(50 / 50 \mathrm{v} / \mathrm{v})$ és DEA $(25 \mathrm{mM})$ és FA $(50 \mathrm{mM})$; áramlási sebesség, $0,6 \mathrm{ml}$ perc $^{-1}$; detektálás, 221-280 $\mathrm{nm}$; hömérséklet-tartomány, $5-50{ }^{\circ} \mathrm{C} ; R^{2}$, ln $\alpha$ és $1 / \mathrm{T}$ függvények korrelációs koeffíciense; $* \mathrm{~T}=5-20^{\circ} \mathrm{C} ; Q=$ $\Delta\left(\Delta H^{\circ}\right) / 298 \times \Delta\left(\Delta S^{\circ}\right)$.

A van’t Hoff egyenlet alapján az $\ln \alpha-1 / T$ függvényében ábrázolt adatok minden esetben lineárisan változtak, vagyis a hőmérséklet-változtatás hatására a szelektor szerkezetében, illetve a királis felismerés folyamatában nem következett be jelentős változás $[84,148]$. A standard entalpiaváltozás különbség értéke $\left(\Delta\left(\Delta \mathbf{H}^{\mathbf{0}}\right)\right)$ megmutatja, hogy milyen könnyen kerülnek a vizsgált enantiomerek a mozgófázisból az állófázisra. A 9. és függelék F9 táblázatok adatainak összehasonlításából látható, hogy a $\Delta\left(\Delta \mathbf{H}^{\mathbf{0}}\right)$ értékek ikerionos szelektorokon -0,6 és -6,0 kJ/mol között, míg anioncserélő állófázisokon -2,1 és - $15,6 \mathrm{~kJ} / \mathrm{mol}$ tartományban változtak. Ikerionos állófázison a 11, míg anioncserélő szelektoron a $\mathbf{1 6}$ vegyület rendelkezett a legnegatívabb $\Delta\left(\Delta \mathbf{H}^{\mathbf{0}}\right)$ értékekkel. Minél negatívabb az entalpiatag, 
annál hatékonyabban megy végbe az enantiomer megkötődése a szelektoron, illetve annál nagyobb az átmeneti komplexet kialakító kölcsönhatások erőssége [92]. Emellett megfigyelhető, hogy minden esetben a kiemelkedő $\Delta\left(\Delta \mathbf{H}^{\mathbf{o}}\right)$ értékekhez társultak a legnagyobb entrópiaváltozás különbségek. Az entrópiaváltozás ikerionos szelektorokon $-0,7$ és -12,0 J/(mol*K), anioncserélő állófázisokon -5,6 és $-42,9 \mathrm{~J} /\left(\mathrm{mol}^{*} \mathrm{~K}\right)$ között változott. Negatív $\Delta\left(\Delta \mathbf{S}^{\mathbf{0}}\right)$ értéket az átmeneti komplex kialakulását kísérő rendezetlenség csökkenés, illetve a megkötött enantiomerek szabadsági fokának a csökkenése eredményezi. Az ioncserélő állófázisokat összehasonlítva a kinidin alapú kolonnákon jellemzően nagyobb entalpia- és entrópiaváltozások tapasztalhatók, mint a kinin alapúakon. Említést érdemel az is, hogy az entalpia és entrópiatagok szélesebb tartományban változtak anioncserélő szelektorok esetén, mint ikerionos kolonnákon. Ez az eltérő viselkedés arra utal, hogy az ikerionos szelektorokon kialakuló kettős ionpár kölcsönhatás jelentősen képes csökkenteni a hőmérséklet-változtatás hatását az elválasztásra. Azonban az entalpia és entrópiatagok összehasonlítása alapján az elválasztást meghatározó folyamatok minden szelektor és mozgófázis esetén azonosak voltak, mivel minden vizsgált vegyület esetén entalpia vezérelt $(Q>1)$ elválasztás figyelhető meg.

A tárgyalt eredmények alapján kijelenthető, hogy a hőmérséklet-változtatás a vizsgált vegyületek és a szelektor szerkezetétől függően eltérően hat a királis felismerés folyamatára, a hőmérséklet-változtatás révén hatékonyabbá tehető a királis vegyületek elválasztása.

\subsubsection{A hőmérséklet hatása az elválasztásra poliszacharid alapú szelektorok esetén}

A poliszacharid alapú állófázisok termodinamikai viselkedésének megismeréséhez normál fázisú körülmények között 10 és $50{ }^{\circ} \mathrm{C}$-os hőmérséklet-tartományban változtatva a hőmérsékletet tanulmányoztam a $\mathbf{2 1}$ és $\mathbf{2 3}$ vegyületek enantioszelektív elválasztását. A 21 és 23 vegyületek szerkezete egyaránt tartalmazza a kiterjedt aromás rendszerrel bíró 1,2,3,4tetrahidro- $\beta$-karbolin molekulát, így számos királis kölcsönhatást tud kialakítani a vizsgált szelektorokkal. Az elválasztásokat az 5.1.2. fejezetben bemutatott eredmények alapján $n$ hexán/2-PrOH $(70 / 30 \quad v / v)$ és DEA $(0,1 \quad v \%)$ mozgófázissal hét poliszacharid alapú állófázison $(I A, I B, I C, I D, I E, I F$ és $I G)$ vizsgáltam. A hőmérséklet-változtatás hatását a kromatográfiás adatokra a függelék F10 táblázata mutatja be. A hőmérsékletnövelés hatására az enantiomerek visszatartása és a szelektivitás minden esetben csökkent. Ez egyezik az 1,2,3,4-tetrahidro- $\beta$-karbolint tartalmazó vegyületek esetén korábban megfigyelt kromatográfiás viselkedéssel [149]. A felbontás a 21 anyag esetén jellemzően nő míg a 23 vegyület esetén általában csökken a hőmérsékletnövelés hatására. A hőmérsékletnövelés 
hatására csökkenő felbontás gyakran megfigyelhető jelenség, mivel az elválasztandó komponensek megkötődése az állófázison általában exoterm folyamat [84], így a nagy hőmérséklet sok esetben nem kedvező az elválasztáshoz. A hőmérséklettel párhuzamosan növekvő felbontást feltehetőleg a csúcsszimmetria, illetve az anyagátasási folyamatok hatékonyságnövekedése okozza.

\begin{tabular}{|c|c|c|c|c|c|c|}
\hline Vegyület & $\begin{array}{c}-\Delta\left(\Delta \mathbf{H}^{\mathbf{0}}\right) \\
(\mathbf{k J} / \mathbf{m o l})\end{array}$ & $\begin{array}{c}-\Delta\left(\Delta \mathbf{S}^{\mathbf{o}}\right) \\
(\mathbf{J} /(\mathbf{m o l} * \mathbf{K})\end{array}$ & $\begin{array}{c}\text { Korrelációs } \\
\text { koeffíciens } \\
\left(R^{2}\right)\end{array}$ & $\begin{array}{c}-\mathrm{T} x \Delta\left(\Delta \mathbf{S}^{0}\right)_{298 \mathrm{~K}} \\
(\mathbf{k J} / \mathbf{m o l})\end{array}$ & $\begin{array}{c}-\Delta\left(\Delta \mathbf{G}^{\mathbf{0}}\right)_{298 \mathrm{~K}} \\
(\mathbf{k J J} / \mathbf{m o l})\end{array}$ & $Q$ \\
\hline \multicolumn{7}{|c|}{$I A$} \\
\hline 21 & \multicolumn{6}{|c|}{ szelektivitás változás kísérleti hibánál kisebb $(1,11-1,10)$} \\
\hline 23 & 7,3 & 21,7 & 0,982 & 6,5 & 0,8 & 1,1 \\
\hline \multicolumn{7}{|c|}{ IB } \\
\hline 21 & \multicolumn{6}{|c|}{ szelektivitás változás kísérleti hibánál kisebb $(1,20-1,21)$} \\
\hline 23 & 10,0 & 25,5 & 0,993 & 7,6 & 2,4 & 1,3 \\
\hline \multicolumn{7}{|c|}{$I C$} \\
\hline 21 & 7,2 & 14,0 & 0,999 & 4,2 & 3,0 & 1,7 \\
\hline 23 & 4,3 & 10,4 & 0,992 & 3,1 & 1,2 & 1,4 \\
\hline \multicolumn{7}{|c|}{$I D$} \\
\hline 21 & 8,6 & 19,2 & 0,999 & 5,7 & 2,9 & 1,5 \\
\hline 23 & & & & & & \\
\hline \multicolumn{7}{|c|}{$\frac{\text { nincs eivalas }}{\boldsymbol{I} \boldsymbol{E}}$} \\
\hline 21 & 1,2 & 2,3 & 0,993 & 0,7 & 0,5 & 1,7 \\
\hline 23 & 3,9 & 8,1 & 0,989 & 2,4 & 1,5 & 1,6 \\
\hline \multicolumn{7}{|c|}{$I F$} \\
\hline 21 & 3,7 & 9,2 & 0,999 & 2,7 & 1,0 & 1,4 \\
\hline 23 & 4,4 & 12,1 & 0,999 & 3,6 & 0,8 & 1,2 \\
\hline \multicolumn{7}{|c|}{$I G$} \\
\hline 21 & 1,3 & 1,1 & 0,987 & 0,3 & 1,0 & 4,3 \\
\hline 23 & 6,8 & 17,4 & 0,999 & 5,2 & 1,6 & 1,3 \\
\hline
\end{tabular}

10. táblázat Termodinamikai paraméterek poliszacharid alapú állófázisokon normál fázisú mozgófázis rendszert alkalmazva

Kromatográfiás körülmények: kolonna, $I A, I B, I C, I D, I E, I F$ és $I G$; mozgófázis, $n$-hexán/2-PrOH $(70 / 30 v / v)$ és DEA $(0,1 v \%)$; áramlási sebesség, $1,0 \mathrm{ml}$ perc ${ }^{-1}$; detektálás, $215-250 \mathrm{~nm}$; hömérséklet-tartomány, $5-50{ }^{\circ} \mathrm{C}$; $R^{2}, \ln \alpha$ és $1 /$ T függvények korrelációs koeffíciense; $Q=\Delta\left(\Delta H^{\circ}\right) / 298 \times \Delta\left(\Delta S^{\circ}\right)$.

A függelék F10 táblázat adataiból, a van’t Hoff egyenlet alapján meghatározott látszólagos termodinamikai paramétereket a 10. táblázat foglalja össze. Mivel az 1/T függvényében ábrázolt $\ln \alpha$ adatok minden esetben lineárisan változtak, ezért feltételezhető, hogy a vizsgált hőmérséklet-tartományban a szelektor szerkezetében, illetve a királis felismerés mechanizmusában nem következett be jelentős változás. A standard entalpiaváltozás különbség értéke $\left(\Delta\left(\Delta \mathbf{H}^{\mathbf{0}}\right)\right)$ hasonló tartományban változott mindkét 
vegyületnél. A 21 vegyület esetén a $\Delta\left(\Delta \mathbf{H}^{\mathbf{0}}\right)$ érték -1,2 és $-8,6 \mathrm{~kJ} / \mathrm{mol}$ között, míg a 23 anyagnál -3,9 és $-10 \mathrm{~kJ} / \mathrm{mol}$ között változott. A standard entrópiaváltozás különbség $\left(\Delta\left(\Delta \mathbf{S}^{\mathbf{0}}\right)\right)$ szélesebb tartományban változott, -1,1 és $-19,2 \mathrm{~J} /\left(\mathrm{mol}^{*} \mathrm{~K}\right)$ között a 21 vegyület, illetve $-8,1$ és $-25,5 \mathrm{~J} /\left(\mathrm{mol}^{*} \mathrm{~K}\right)$ között a 23 anyag esetén.

Áttekintve a szelektorok szerkezetét, látható, hogy a trisz-(3,5-dimetilfenil-karbamát)-ot tartalmazó $I A$ és $I B$ kolonnán nagyon kis hatással van 21 vegyület elválasztására a hőmérséklet-változtatás. Tehát a szelektor alapvázától függetlenül, a trisz-(3,5-dimetilfenilkarbamát) szelektorral kialakuló kölcsönhatások kevésbé függenek a hömérséklettől, mint a klór szubsztituenst tartalmazó szelektorral kialakuló kölcsönhatások. A többi kolonnán meghatározott termodinamikai értékek hasonló mértékben változtak mindkét anyag esetén. Vagyis a cellulóz és az amilóz alapváz szerkezete azonos módon hat az elválasztásra a hőmérséklet-változtatás során. Emellett az is kijelenthető, hogy a szelektor alapvázát módosító csoportok térszerkezete csekély mértékben befolyásolja a kromatográfiás sajátságok változását a hőmérséklet-változtatás függvényében. Az entalpia- és entrópiaváltozás összehasonlítása alapján az elválasztást meghatározó folyamatok minden oszlop esetén azonosak voltak és mindkét vizsgált vegyület esetén entalpiavezérelt $(Q>1)$ elválasztás figyelhető meg.

\subsubsection{A hőmérséklet hatása az elválasztásra SFC technika esetén}

\subsubsection{A hőmérséklet hatása SFC technika és cinkóna alkaloid alapú szelektorok alkalmazása esetén}

A hőmérséklet-változtatás sokrétű hatást fejthet ki az SFC technikával végzett királis elválasztásra. Ha az alkalmazott mozgófázis kis mennyiségü módosítót tartalmaz, vagyis a sürüsége kicsi, akkor a hőmérséklet emelés hatására kezdetben általában nő a visszatartás mértéke [66]. Ezt a HPLC technikától eltérő viselkedést az eluens sürüségének további csökkenése és a szelektor felületén adszorbeált mozgófázis réteg csökkenésének együttes hatása okozza. A hőmérséklet további emelése a visszatartás csökkenéséhez vezethet, eluens módosítótól, ellennyomástól és a vizsgált anyagtól függően, mivel az elválasztandó komponensek illékonysága csökkenti a visszatartást. Ezzel szemben a sok módosítót tartalmazó nagy sürüségű SFC eluens esetén a hőmérséklet emelése jellemzően a visszatartás csökkenését okozza. Mivel számos egyedi tényező eredő hatása vezet a királis elválasztáshoz SFC technika esetén, ezért nem minden esetben célszerü a HPLC és SFC technikával kapott termodinamikai adatokat közvetlenül összehasonlítani [66]. 
A cinkóna alkaloid alapú állófázisok SFC technikával történő használata során megvizsgáltam a hőmérséklet-változtatás hatását az elválasztásra kis és nagy sürüségü mozgófázis alkalmazása esetén. Ehhez mozgófázisként, az 5.1.3. fejezet adatai alapján a 17 és 18 vegyület esetén $\mathrm{CO}_{2} / \mathrm{MeOH} 70 / 30(v / v)$ és DEA (30 mM) és FA (60 mM), míg a 26 és 27 vegyület esetén $\mathrm{CO}_{2} / \mathrm{MeOH} 95 / 5(v / v)$ és DEA $(30 \mathrm{mM})$ és FA $(60 \mathrm{mM})$ összetételt használtam. Mivel a 26 és 27 vegyületek csak egy tercier amincsoportot tartalmaznak, ezért az ioncserélő állófázisok esetén a visszatartást meghatározó ionos kölcsönhatások jelentősen gyengébb hatást tudnak kifejteni rájuk. Így ezek a vegyületek $Z W I X(+)$ és $Z W I X(-)$ állófázisokat használva kisebb elúciós erősségü, kis sürüségü mozgófázissal is elválaszthatók. Az SFC technikával 20-50 ${ }^{\circ} \mathrm{C}$ hőmérséklet-tartományban végzett elválasztások kromatográfiás adatait az F11 táblázat foglalja össze.

A függelék F11 táblázatban látható, hogy a nagy sűrüségü mozgófázist alkalmazva (17 és 18 vegyület), a hömérséklet növelés hatására a visszatartás és a szelektivitás minden esetben csökkent. Ezzel szemben a kis sürüségü eluens esetén a hőmérsékletnövelés hatására a visszatartás növekedett, míg a szelektivitás csökkent. Vagyis függetlenül az alkalmazott szelektorok szerkezetétől, az SFC mozgófázis sürüségünek hatására a visszatartás a szakirodalomban leírtakkal összhangban változik [66]. Mindkét szelektoron megfigyelhetö, hogy nagy sürüségü eluens esetén a felbontás értékek viszonylag szük tartományban változtak, míg kis sủrüségủ eluenst használva csökkentek a hőmérsékletnövelés hatására.

\begin{tabular}{|c|c|c|c|c|c|c|c|}
\hline Vegyület & Eluens & $\begin{array}{l}-\Delta\left(\Delta \mathbf{H}^{0}\right) \\
(\mathbf{k J} / \mathbf{m o l})\end{array}$ & $\begin{array}{c}-\Delta\left(\Delta \mathbf{S}^{\mathbf{0}}\right) \\
(\mathbf{J} /(\mathbf{m o l} * \mathbf{K})\end{array}$ & $\begin{array}{c}\text { Korrelációs } \\
\text { koeffíciens } \\
\left(R^{2}\right)\end{array}$ & $\begin{array}{c}-\mathrm{T} x \Delta\left(\Delta \mathbf{S}^{\mathrm{o}}\right)_{298 \mathrm{~K}} \\
\quad(\mathrm{~kJ} / \mathbf{m o l})\end{array}$ & $\begin{array}{c}-\Delta\left(\Delta \mathbf{G}^{0}\right)_{298 \mathrm{~K}} \\
(\mathbf{k J} / \mathbf{m o l})\end{array}$ & $Q$ \\
\hline & \multicolumn{7}{|c|}{$Z W I X(+)$} \\
\hline 17 & $\mathrm{a}$ & \multicolumn{6}{|c|}{ szelektivitás változás kísérleti hibánál kisebb $(1,00-1,02)$} \\
\hline 18 & a & 3,0 & 5,5 & 0,987 & 1,6 & 1,4 & 1,9 \\
\hline 26 & $\mathrm{~b}$ & 1,4 & 4,0 & 0,994 & 1,2 & 0,2 & 1,2 \\
\hline 27 & $\mathrm{~b}$ & 0,8 & 2,1 & 0,992 & 0,6 & 0,2 & 1,3 \\
\hline \multicolumn{8}{|c|}{$Z W I X(-)$} \\
\hline 17 & a & 1,2 & 1,6 & 0,991 & 0,5 & 0,7 & 2,4 \\
\hline 18 & $\mathrm{a}$ & 2,3 & 3,8 & 0,992 & 1,1 & 1,2 & 2,1 \\
\hline 26 & $\mathrm{~b}$ & 0,8 & 1,9 & 0,996 & 0,6 & 0,2 & 1,3 \\
\hline 27 & $\mathrm{~b}$ & 0,9 & 1,9 & 0,987 & 0,6 & 0,3 & 1,5 \\
\hline
\end{tabular}

11. táblázat Termodinamikai paraméterek cinkóna alkaloid alapú állófázisok és SFC technika alkalmazása esetén

Kromatográfiás körülmények: kolonna, $Z W I X(+)$ és $Z W I X(-)$; mozgófázis, a, $\mathrm{CO}_{2} / \mathrm{MeOH} 70 / 30(v / v)$ és DEA (30 mM) és FA (60 mM), b, $\mathrm{CO}_{2} / \mathrm{MeOH}$ 95/5 ( $\left.v / v\right)$ és DEA (30 mM) és FA (60 mM); áramlási sebesség, 2,0 $\mathrm{ml}$ perc ${ }^{-1}$; detektálás, $215-250 \mathrm{~nm}$; hömérséklet-tartomány, $20-50{ }^{\circ} \mathrm{C}$; ellennyomás 150 bar; $R^{2}$, ln $\alpha$ és $1 / \mathrm{T}$ függvények korrelációs koeffíciense; $Q=\Delta\left(\Delta H^{\circ}\right) / 298 \times \Delta\left(\Delta S^{\circ}\right)$.

A függelék F11 táblázat adataiból a van’t Hoff egyenlet segítségével kiszámoltam a királis elválasztást jellemző látszólagos termodinamikai paramétereket, ezeket a 
11. táblázat foglalja össze. Az $1 / \mathrm{T}$ függvényében ábrázolt $\ln \alpha$ adatok mindkét oszlopon lineárisan változtak, vagyis a hömérséklet-változtatás hatására sem a királis felismerés folyamatában, sem a szelektor szerkezetében nem következett be számottevő változás. Mind a $\Delta\left(\Delta \mathbf{H}^{\mathbf{0}}\right)$ értékek (-0,8 és $\left.-3 \mathrm{~kJ} / \mathrm{mol}\right)$, mind a $\Delta\left(\Delta \mathbf{S}^{\mathbf{0}}\right)$ értékek (-1,9 és $\left.-5,5 \mathrm{~J} /\left(\mathrm{mol}^{*} \mathrm{~K}\right)\right)$ szük tartományban változtak. Tehát a hőmérséklet-változtatás csekély mértékben befolyásolta az elválasztandó komponensek megkötődését az állófázison. Az entalpia- és entrópiaváltozás értékeket összehasonlítva látható, hogy az elválasztás mindkét oszlop esetén, az eluenstől függetlenül, entalpiavezérelt volt. Vagyis a bázikus 17 vegyület és az amfolit 18 anyag ionos kölcsönhatásai határozzák meg a retenciós viselkedést, melyet a hőmérséklet-változtatás kevésbé befolyásol.

\subsubsection{A hőmérséklet hatása SFC technika és poliszacharid alapú szelektorok alkalmazása esetén}

A poliszacharid alapú állófázisok SFC technikával történő használata során a hőmérséklet-változás jelentős hatással lehet a királis felismerés folyamatára [150]. E hatások megismerése és megértése érdekében tanulmányoztam négy poliszacharid alapú királis állófázison a 17-22 és 26-29 vegyületek kromatográfiás sajátságait a hőmérséklet-változtatás függvényében. A 17-22 vegyületek lehetőséget adnak analóg szerkezetü aromás rendszert tartalmazó bázikus és amfolit vegyületek kromatográfiás viselkedésének összehasonlítására. A 26-29 vegyületek vizsgálatával a klór és metoxicsoportok hozzáadásának elválasztásra gyakorolt hatása ismerhető meg. Emellett az $I A, I B, I C$ és $I E$ kolonnák alkalmazása lehetőséget teremt a cellulóz és amilóz alapváz, illetve a trisz-(3,5-dimetilfenil-karbamát) és trisz-(3,5-diklórfenil-karbamát) módosítók hatásának összehasonlítására. A hőmérsékletváltoztatást $20-50{ }^{\circ} \mathrm{C}$-os tartományban vizsgáltam. Az így kapott kromatográfiás adatokat a függelék F12-F15 táblázatok mutatják be.

A függelék F12-F15 táblázatokban látható, hogy a hömérsékletnövelés hatására a $k_{l}$ értékek minden esetben csökkentek. A szelektivitás értékek a hőmérsékletnövelés hatására jellemzően csökkentek vagy csekély mértékben változtak. Ez alól a legtöbb kivétel az IE kolonna esetén figyelhető meg, melynél a 17, 19, 26, 27 és 29 vegyületekre meghatározott szelektivitás enyhén növekedett a hőmérséklettel. A felbontás az enantioszelektivitáshoz hasonlóan jellemzően csökkent a hőmérséklet emelés hatására, azonban néhány esetben növekvő értékek is megfigyelhetők voltak.

A függelék F12-F15 táblázatok kromatográfiás adatait felhasználva a van’t Hoff egyenlet alapján kiszámoltam az elválasztásokat jellemző látszólagos termodinamikai értékeket, melyek a 12. táblázatban láthatók. Az $\ln \alpha-1 / \mathrm{T}$ függvény mind a négy oszlopon, minden vizsgált vegyület esetén lineárisan illeszthető, vagyis a hőmérséklet-változtatás 
hatására a királis felismerés folyamatában, valamint a szelektor szerkezetében nem következett be jelentős változás. A $\Delta\left(\Delta \mathbf{H}^{\mathbf{0}}\right)$ értékek $(-3,6$ és $1,8 \mathrm{~kJ} / \mathrm{mol})$, illetve a $\Delta\left(\Delta \mathbf{S}^{\mathbf{o}}\right)$ értékek (-6,4 és $\left.7 \mathrm{~J} /\left(\mathrm{mol}^{*} \mathrm{~K}\right)\right)$ jellemzően szük tartományban változtak, kivéve az $I A$ oszlopon elválasztott 18, 20 és 22 amfolit vegyületek esetén. Minden esetben a negatív $\Delta\left(\Delta \mathbf{H}^{\mathbf{0}}\right)$ értékekhez negatív $\Delta\left(\Delta \mathbf{S}^{\mathbf{0}}\right)$ társult és az elválasztás entalpiavezérelt $(Q>1)$ volt.

Ezzel szemben a pozitív $\Delta\left(\Delta \mathbf{H}^{\mathbf{0}}\right)$ értékek mellé minden esetben pozitív $\Delta\left(\Delta \mathbf{S}^{\mathbf{0}}\right)$ társult. A pozitív entalpia- és entrópiaváltozás értékek esetén rendhagyó kromatográfiás viselkedés figyelhető meg, a hömérsékletnövelés hatására a $k_{l}$ csökken, míg a szelektivitás növekszik. Erre példák az $I B$ oszlopon mért 22, $I C$ oszlopon mért 26 és 29, valamint az $I E$ oszlopon mért 17, 19, 26, 27 és 29 vegyületek. E szokatlan termodinamikai viselkedést feltehetőleg az entrópiatag jelentős hozzájárulása okozza. $\mathrm{Az}$ enantiomerek állófázison való megkötődése során a rendszer rendezetlensége, illetve a szabadsági fokok száma csökken. Azonban a megkötődés során a szelektor és az elválasztandó vegyület szolvátburkának egy része lehasad és a tömbfázisba kerül, így a rendszer teljes rendezetlensége és a szabadsági fokok száma növekszik. Ez az utóbbi hatás határozza meg a királis elválasztás folyamatát a rendhagyó viselkedés során. Ezt támasztja alá az is, hogy a felsorolt kivételek esetén az entrópiaváltozás értékek nagyobbak, mint az entalpiaváltozásból származó energia felszabadulás $(Q<1)$, tehát az elválasztás entrópiavezéreltként jellemezhető. Ez a viselkedés arra utal, hogy SFC technika esetén a királis felismerésért felelős kötőhelyek környezetére jelentős hatást gyakorolhat a folyékony szén-dioxid. Ezt a megfigyelést erősíti az IC kolonnán vizsgált bázikus és amfolit 17-22 vegyületek is. Annak ellenére, hogy poliszacharid alapú szelektorok esetén a királis felismerés folyamatában nem töltenek be meghatározó szerepet az ionos kölcsönhatások említést érdemel, hogy a bázikus 17, 19, 21 vegyületek esetén nincs királis felismerés, míg az amfolit 18, 20, 22 vegyületek enantiomerei elválnak.

Összevetve az amilóz és cellulóz alapú állófázisokat ( $I A$ és $I B$, illetve $I E$ és $I C$ ), termodinamikai szempontból nem látható jellegzetes különbség köztük. Ezzel szemben, a trisz-(3,5-dimetilfenil-karbamát) módosító hatását a trisz-(3,5-diklórfenil-karbamát) hatásával összevetve ( $I A$ és $I E, I B$ és $I C$ ) látható, hogy a 26-29 vegyületek esetén a klórt tartalmazó szelektorokon több esetben entrópiavezérelt elválasztás figyelhető meg. Ez alapján, a szelektoron található metilcsoportok klórra cserélésével, jelentősen megváltoztatható az elválasztás energetikai folyamata. Vagyis megállapítható, hogy SFC technika esetén a klór csoport által kialakított kölcsönhatások jelentős hatással vannak az elválasztás folyamatára. 


\begin{tabular}{|c|c|c|c|c|c|c|}
\hline Vegyület & $\begin{array}{l}-\Delta\left(\Delta \mathbf{H}^{0}\right) \\
(\mathbf{k J} / \mathbf{m o l})\end{array}$ & $\begin{array}{c}-\Delta\left(\Delta \mathbf{S}^{\mathbf{o}}\right) \\
\left(\mathbf{J} /\left(\mathbf{m o l} \mathbf{l}^{* \mathbf{K}}\right)\right.\end{array}$ & $\begin{array}{c}\text { Korrelációs } \\
\text { koeffíciens } \\
\left(R^{2}\right)\end{array}$ & $\begin{array}{c}-\mathrm{T} x \Delta\left(\Delta \mathrm{S}^{\mathrm{o}}\right)_{298 \mathrm{~K}} \\
\quad(\mathrm{~kJ} / \mathrm{mol})\end{array}$ & $\begin{array}{c}-\Delta\left(\Delta \mathbf{G}^{\mathbf{0}}\right)_{298 \mathrm{~K}} \\
(\mathbf{k J} / \mathbf{m o l})\end{array}$ & $Q$ \\
\hline \multicolumn{7}{|c|}{ IA } \\
\hline 17 & \multicolumn{6}{|c|}{ szelektivitás változás kísérleti hibánál kisebb $(1,18-1,20)$} \\
\hline 18 & 15,0 & 45,4 & 0,991 & 13,5 & 1,5 & 1,1 \\
\hline 19 & \multicolumn{6}{|c|}{ nincs elválás } \\
\hline 20 & 35,9 & 106,8 & 0,991 & 31,8 & 4,10 & 1,1 \\
\hline 21 & 3,6 & 9,3 & 0,993 & 2,8 & 0,8 & 1,3 \\
\hline 22 & 15,4 & 47,4 & 0,993 & 14,1 & 1,4 & 1,1 \\
\hline 26 & 1,0 & 1,5 & 0,999 & 0,4 & 0,6 & 2,5 \\
\hline 27 & 1,0 & 2,4 & 0,996 & 0,7 & 0,3 & 1,4 \\
\hline 28 & 1,8 & 4,1 & 0,995 & 1,2 & 0,6 & 1,5 \\
\hline 29 & 0,9 & 1,2 & 0,990 & 0,4 & 0,5 & 2,3 \\
\hline \multicolumn{7}{|c|}{$I B$} \\
\hline 17 & 1,0 & 2,7 & 0,993 & 0,8 & 0,2 & 1,3 \\
\hline 18 & & & nincs elválás & & & \\
\hline 19 & & & nincs elválás & & & \\
\hline 20 & 2,9 & 7,6 & 0,992 & 0,9 & 2,0 & 3,2 \\
\hline 21 & & & nincs elválás & & & \\
\hline 22 & $-1,8$ & $-7,0$ & 0,995 & $-2,1$ & 0,3 & 0,9 \\
\hline 26 & 0,8 & 0,6 & 0,992 & 0,2 & 0,6 & 4,0 \\
\hline 27 & 0,7 & 0,7 & 0,995 & 0,2 & 0,5 & 3,5 \\
\hline 28 & 0,7 & 0,6 & 0,999 & 0,2 & 0,5 & 3,5 \\
\hline 29 & 0,8 & 0,7 & 0,992 & 0,2 & 0,6 & 4,0 \\
\hline \multicolumn{7}{|c|}{$I C$} \\
\hline 17 & & & nincs elválás & & & \\
\hline 18 & 2,3 & 0,2 & 0,998 & 0,1 & 2,2 & 23 \\
\hline 19 & & & nincs elválás & & & \\
\hline 20 & 1,5 & 0,2 & 0,998 & 0,1 & 1,4 & 15 \\
\hline 21 & & & nincs elválás & & & \\
\hline 22 & 2,2 & 0,2 & 0,999 & 0,1 & 2,1 & 22 \\
\hline 26 & $-1,0$ & $-6,0$ & 0,991 & $-1,8$ & 0,8 & 0,6 \\
\hline 27 & 0,8 & 0,7 & 0,998 & 0,2 & 0,6 & 4,0 \\
\hline 28 & 0,9 & 0,2 & 0,994 & 0,1 & 0,8 & 9,0 \\
\hline 29 & $-0,9$ & $-5,5$ & 0,998 & $-1,6$ & 0,7 & 0,6 \\
\hline \multicolumn{7}{|c|}{$I E$} \\
\hline 17 & $-1,2$ & $-4,5$ & 0,997 & $-1,3$ & 0,1 & 0,9 \\
\hline 18 & 0,5 & 0,2 & 0,999 & 0,1 & 0,4 & 5,0 \\
\hline 19 & $-0,9$ & $-3,7$ & 0,996 & $-1,1$ & 0,2 & 0,8 \\
\hline 20 & 2,5 & 6,0 & 0,998 & 1,8 & 0,7 & 3,6 \\
\hline 21 & 1,4 & 3,1 & 0,997 & 0,9 & 0,5 & 1,6 \\
\hline 22 & 3,3 & 6,4 & 0,999 & 1,9 & 1,4 & 1,7 \\
\hline 26 & $-0,6$ & $-4,3$ & 0,991 & $-1,3$ & 0,7 & 0,5 \\
\hline 27 & $-0,9$ & $-5,0$ & 0,995 & $-1,5$ & 0,6 & 0,6 \\
\hline 28 & $-0,1$ & $-2,8$ & 0,999 & $-0,8$ & 0,7 & 0,1 \\
\hline 29 & $-0,6$ & $-4,4$ & 0,993 & $-1,3$ & 0,7 & 0,9 \\
\hline
\end{tabular}

12. táblázat Termodinamikai adatok poliszacharid alapú állófázisok és SFC technika esetén Kromatográfiás körülmények: kolonna, $I A, I B$, IC és $I E$; mozgófázis, $\mathrm{CO}_{2} / \mathrm{MeOH} 50 / 50(v / v)$ és DEA (20 mM); áramlási sebesség, 2,0 $\mathrm{ml} \mathrm{perc}^{-1}$; detektálás, $215-250 \mathrm{~nm}$; hőmérséklet-tartomány, $20-50^{\circ} \mathrm{C}$; ellennyomás 150 bar; $R^{2}, \ln \alpha$ és $1 /$ T függvények korrelációs koeffíciense; $Q=\Delta\left(\Delta H^{\circ}\right) / 298 \times \Delta\left(\Delta S^{\circ}\right)$. 


\section{6. ÖSSZEFOGLALÁS}

Munkám során változatos működési mechanizmusú királis kolonnák elválasztóképességét tanulmányoztam biológiai és gyógyszeripari szempontból jelentős vegyületek sztereoizomerjeinek elválasztásával. A kromatográfiás körülmények rendszerezett változtatásával vizsgáltam a királis felismerés folyamatát nagyhatékonyságú folyadékkromatográfia (HPLC) és szuperkritikus folyadékkromatográfia (SFC) alkalmazása esetén.

\section{A cinkóna alkaloid alapú szelektorok alkalmazásával megvizsgáltam a mozgófázis összetétel hatását a királis elválasztásra.}

Meghatároztam a cinkóna alkaloid alapú állófázisok esetén széles körben alkalmazott poláris-ionos $\mathrm{MeOH} / \mathrm{MeCN}$ eluensrendszer összetételének korlátait HPLC technika használatakor. Az eluens legalább $20 v \%$ és legfeljebb $80 v \% \mathrm{MeOH}$-t szükséges, hogy tartalmazzon a gyakorlatban is hasznosítható királis elválasztáshoz. Kimutattam, hogy minden vizsgált vegyület esetében, az összes vizsgált ioncserélő állófázison, a $\mathrm{MeOH}$ tartalom csökkentésének hatására a vizsgált vegyületek visszatartása nőtt. A HPLC mozgófázisában található MeCN-t helyettesítettem hasonlóan poláris aprotikus THF-nal, azonban ez jellemzően nem növelte az állófázisok elválasztóképességet.

Bázikus és amfolit vegyületek monoionos és ikerionos állófázisokon való elválasztása során igazoltam az ikerionos állófázisokon kialakuló kettős ionpár kölcsönhatás jelenlétét. Ez a hatás a HPLC és az SFC technika esetén egyaránt a visszatartás jelentős növekedését okozta. A HPLC és SFC technika összehasonlításával megállapítottam, hogy a $\mathrm{MeOH}$ tartalom csökkentésének hatására a nem enantioszelektív ionos kölcsönhatások az SFC technika esetén jelentősen felerősödtek, így a vizsgált vegyületek kiemelkedő visszatartással rendelkeztek. Azonban a két technika enantiomer megkülönböztető képessége nem tért el meghatározóan egymástól.

\section{Poliszacharid alapú szelektorokat alkalmazva felderítettem az eluensösszetétel változtatás hatását a királis elválasztásra.}

A módosított poliszacharid alapú állófázisokat normál fázisú körülmények között használva megvizsgáltam az eluensben található alkohol mennyiségének és anyagi minőségének hatását az elválasztásra. Megfigyeltem, hogy HPLC technika esetén az alkohol szénláncának növekedésével ( $\mathrm{EtOH}, 1-\mathrm{PrOH}, \mathrm{BuOH})$ a visszatartás jellemzően enyhén csökkent, azonban a szelektivitás és felbontás értékek többnyire rendszertelen módon változtak. A vizsgált vegyületek esetén az eluens alkoholtartalmának csökkentése a 
visszatartás és a felbontás növekedéséhez vezetett, valamint a szelektoron található klór szubsztituens számának csökkentése szintén növelte a visszatartást.

Az SFC technika esetén az eluensben található alkohol anyagi minősége a HPLC technikánál tapasztaltaktól eltérő kromatográfiás viselkedést okozott, azonban a szelektor polaritását meghatározó klór szubsztituens számának csökkentése ez esetben is növelte a visszatartást. Az SFC mozgófázishoz adott alkil-amin módosítók összehasonlítása alapján a hozzáadott bázis anyagi minősége jelentősen nem befolyásolta az elválasztási tulajdonságokat. A mozgófázis alkoholtartalmának csökkentése SFC technika esetén is a visszatartás növekedését eredményezte, azonban a felbontás a HPLC-nél megfigyeltektől eltérően, az alkalmazott szelektor szerkezetétől függően változott.

\section{Áttekintettem a HPLC és SFC technika mozgófázisához adott ionos módosítók hatását cinkóna alkaloid alapú kolonnák esetén.}

A királis vegyületek cinkóna alkaloid alapú ioncseréló állófázisokkal való elválasztásakor a kromatográfiás rendszerben található ionok mennyisége meghatározza az enantiomerek visszatartását. Az alanil-triptofán amfolit dipeptid HPLC-s vizsgálatával igazoltam, hogy ikerionos kolonnák használatakor az ismételhető enantioszelektív elválasztáshoz nélkülözhetetlen a sav és bázis módosítók egyidejű hozzáadása a mozgófázishoz.

A sav és bázis módosítók koncentrációjának változtatásával a vizsgált vegyületek szerkezetétöl függetlenül mind HPLC, mind SFC használatakor, a sztöchiometrikus helyettesítési modellel leírható a vizsgált vegyületek kromatográfiás viselkedése. A HPLC és SFC technika esetén egyaránt igazoltam, hogy ikerionos állófázisok használatakor a bázikus vegyületekhez képest az amfolit vegyületek visszatartása kevésbé függ a hozzáadott módosítók mennyiségétől.

\section{Számos vegyület felhasználásával megvizsgáltam a cinkóna alkaloid alapú kolonnák használatakor a molekulaszerkezet és a kromatográfiás jellemzők összefüggéseit.}

A változatos összetételü és szerkezetű amfolit dipeptid vegyületek HPLC technikával meghatározott kromatográfiás adatai alapján ikerionos szelektorok esetén a dipeptid $\mathrm{N}$ terminálisának környezete jelentősen javíthatja az enantioszelektivitást, függetlenül attól, hogy található-e kiralitás centrum a közelében. Emellett megfigyeltem, hogy a dipeptid $C$ terminálisának közelében található oldallánc aromás jellegének növelése, illetve az aromás gyürü funkciós csoportokkal való bővítése, H-híddal, $\pi$ - $\pi$ kölcsönhatások kialakításával és sztérikus hatások révén, jelentősen növelheti az állófázis enantiomerfelismerő képességét. 
Dipeptid vegyületek diasztereomerjeinek elválasztásával bővítettem az ikerionos állófázisok felhasználási körét. A HPLC és SFC technika összehasonlítása alapján megállapítottam, hogy a szelektivitás és felbontás értékek nem tértek el jelentősen egymástól, így a királis felismerést meghatározó kölcsönhatások függetlenek az alkalmazott technikától.

\section{Tanulmányoztam a poliszacharid alapú kolonnák alkalmazásakor a vizsgált}

\section{komponensek szerkezete és a retenciós sajátságok közötti kapcsolatot.}

A HPLC és az SFC technika vizsgálata alapján megállapítottam, hogy a királis felismerés folyamatára egyaránt meghatározó hatással van a poliszacharid alaplánc szerkezete, illetve a hozzá kapcsolt módosítók minősége és térállása. HPLC technika normál fázisú körülmények közötti használatakor a jelentősen poláris amfolit indol vegyületek nem rendelkeznek visszatartással, míg az SFC technika alkalmazásával sikeresen elválaszthatók. Így a két technika használata során a királis felismerésért felelős kölcsönhatások a kromatográfiás körülmények függvényében különböznek.

$\mathrm{Az}$ 1,2,3,4-tetrahidroizokinolin-vázas származékok molekulatérfogatának növelése a vegyületek visszatartásának emelkedéséhez vezetett. HPLC használatakor nagyobb, SFC esetén enyhébb visszatartás növekedést figyeltem meg, amik alapján a vizsgált vegyületek mérete eltérő mértékben van hatással a visszatartásra. Összességében az SFC technika többször eredményezett sikeres elválasztást, mint a HPLC, azonban a HPLC technika használatával is számos esetben elérhető volt az alapvonalra történő elválasztás.

\section{Megvizsgáltam a hőmérséklet hatását az elválasztásra cinkóna alkaloid alapú állófázisok használatakor.}

HPLC technikával a hömérséklet változtatás hatását azonos kolonnán vizsgálva megállapítottam, hogy a tanulmányozott komponensek általában azonos kromatográfiás sajátságokkal bírtak, ezért a szelektor térszerkezete határozza meg a kromatográfiás viselkedést. Minden kolonna esetén a hőmérséklet növelés hatására a szelektivitás értékek csökkentek, miközben a visszatartás, a $Z W I X(+)$ kolonnán csökkent, a többi állófázis használatakor pedig növekedett.

A HPLC-s adatokkal ellentétben megállapítottam, hogy az SFC technika használatakor a szelektor térszerkezetétől függetlenül a mozgófázis sürüsége határozza meg a visszatartás alakulását. Nagy sűrüségü eluenst alkalmazva a visszatartás mindig csökkent a hőmérséklet növelés hatására, míg kis sürüségü eluens használatakor a visszatartás növekedett. Az SFC 
technika esetén, a HPLC-hez hasonlóan, a hőmérséklet emelés hatására a szelektivitás minden alkalommal csökkent.

A van’t Hoff egyenlet segítségével kiszámoltam a királis elválasztást jellemző látszólagos termodinamikai paramétereket. Ezek alapján a hőmérséklet-változtatás hatására a királis felismerés mechanizmusában nem történt változás és mindkét technikánál kizárólag entalpiavezérelt elválasztás volt megfigyelhető.

Meghatároztam a poliszacharid alapú kolonnák alkalmazásakor a hőmérsékletváltoztatás elválasztásra gyakorolt hatását.

A poliszacharid alapú állófázisok használatakor, a HPLC és az SFC technikánál egyaránt, minden alkalommal csökkent a vizsgált komponensek visszatartása a hőmérséklet növelés hatására. A szelektivitás HPLC esetén mindig, az SFC technikát használva általában ellentétesen változott a hőmérséklettel. A van’t Hoff egyenlet segítségével kiszámolt látszólagos termodinamikai paraméterek alapján a hőmérséklet növelés hatására csökkenő szelektivitás entalpiavezérelt elválasztásra jellemző. Az SFC technika esetén megfigyelhető hőmérséklettel párhuzamosan változó szelektivitás értékek entrópiavezérelt elválasztásokat jellemeznek. Ezek alapján megállapítható, hogy a királis felismerésért felelős kötőhelyek környezetére jelentős hatást gyakorolhat a folyékony szén-dioxid. A hőmérséklet-változtatás hatására az elválasztás mechanizmusa egyik módszernél sem változott.

Méréseim alapján kijelenthető, hogy a HPLC és SFC módszerek egymást kiegészítő technikaként jól használhatók királis vegyületek enantioszelektív elválasztására. 


\section{SUMMARY}

During my work I investigated the separation performance of chiral columns with diverse operating principle by separating the stereoisomers of biologically and pharmaceutically important compounds. I studied the chiral recognition mechanism by systematically changing the chromatographic conditions of high-performance liquid chromatography (HPLC) and Supercritical fluid chromatography (SFC).

\section{By using cinchona alkaloid-based selectors I investigated the effect of the mobile phase composition on chiral separation.}

I determined the composition limits of the widely used polar-ionic $\mathrm{MeOH} / \mathrm{MeCN}$ eluent system in case of HPLC and cinchona alkaloid-based stationary phases. The eluent should contain at least $20 v \%$ and at most $80 \nu \% \mathrm{MeOH}$ to provide practically useful chiral separation. It was determined that a decrease in $\mathrm{MeOH}$ content in the mobile phase resulted in increased retention times for all the investigated compounds on every ion-exchanger stationary phase. Substitution of the HPLC mobile phase's MeCN content with a similarly aprotic THF did not increase the separation performance.

By separating basic and amphoteric compounds with monoionic and zwitterionic stationary phases the presence of the double ion pairing interaction on zwitterionic stationary phases was established. This interaction leads to a significant increase in retention for both HPLC and SFC methods. By comparing HPLC and SFC separations it was determined that the decrease of $\mathrm{MeOH}$ content lead to stronger non-enantioselective interactions for SFC, hence the measured compounds had outstanding retention. However, the enantiomer recognition ability of the two methods did not differ notably from each other.

\section{By using polysaccharide-based selectors I explored the effect of the mobile phase composition on chiral separation.}

I have examined the effects of the nature and amount of alcohol found in the eluent while using modified polysaccharide-based stationary phases and normal-phase HPLC method. It was established, that the increase of the alcohol's carbon chain length (EtOH, 1-PrOH, $\mathrm{BuOH})$ resulted in a slight decrease of retention, however the selectivity and resolution values have changed mostly unsystematically. Decrease of the mobile phase's alcohol content has caused the increase of the retention and the resolution, what is more, reducing the number of chlorine substituents on the selector has also enhanced the retention.

The effects of the nature of alcohol on the chromatographic behaviour differed under SFC conditions from the HPLC results. However, reducing the number of the polar chlorine 
substituents on the selector has increased the retention under these conditions too. According to the comparison of the alkyl-amine additives in the SFC eluent, the nature of base additives did not affect the properties of the separation. Decreasing the alcohol content of the SFC mobile phase resulted in a retention increase that was similar to the HPLC mode, however, in contrast with the HPLC results, the resolution was dependant on the structure of the selector.

I reviewed the effect of the ionic modifiers added to the HPLC and SFC mobile phases using cinchona alkaloid-based columns.

For the separation of chiral compounds on cinchona alkaloid-based ion-exchanger stationary phases, the concentration of ionic modifiers in the chromatographic system defines the enantiomers' retention. By investigating the amphoteric alanyl-tryptophan dipeptide using the HPLC method it was verified that in order to use zwitterionic columns for repeatable enantioselective separation, it is essential to add acidic and basic modifiers simultaneously to the mobile phase.

By changing the concentration of the acidic and basic modifiers in the mobile phase the chromatographic behaviour of the examined compounds can be described, either using the HPLC or the SFC method with the stoichiometric displacement model irrespectively of the structure of the compounds. It was established for both HPLC and SFC techniques that, in case of using zwitterionic stationary phases, the retention of the amphoteric compounds depends less on the added modifiers concentration than on the basic compounds' retention.

By separating numerous compounds on cinchona alkaloid-based columns, I investigated the correspondence between the compound's structure and the chromatographic parameters.

According to the HPLC chromatographic data of amphoteric dipeptides with diverse structure and composition, in case of zwitterionic selectors, the environment of the $\mathrm{N}$ terminus of the dipeptide can markedly improve enantioselectivity, whether or not a chiral centre is located nearby. In addition, it was observed that the increasing the aromaticity of the sidechain or the substitution on the aromatic ring with functional groups close to the dipeptide's $C$-terminus can significantly increase the enantiomer recognition ability of the stationary phase via H-bonding, $\pi-\pi$ interactions or steric effects.

By separating dipeptide diastereomers the zwitterionic stationary phases scope of use was expanded. Based on the comparison of the HPLC and SFC methods it was established that 
the selectivity and resolution values did not differ markedly from each other, therefore the defining interactions of the chiral recognition are independent of the applied method.

\section{I studied the relationship between the compound's structure and the chromatographic parameters using polysaccharide-based columns.}

By investigating the HPLC and SFC methods it was determined that the structure of the polysaccharide backbone or the nature and spatial position of the connected modifiers are equally important in the chiral recognition process. The highly polar amphoteric indole compounds do not have retention when using normal-phase HPLC methods, while they can be successfully separated by using the SFC method. Hence the interactions responsible for the chiral recognition differ depending on the chromatographic circumstances of the two separation techniques.

Increasing the molecular volume of 1,2,3,4-tetrahydroquinoline based compounds lead to increased retention. The observed retention growth was higher for HPLC than SFC, therefore the retention is affected in varying degrees by molecular volume. Overall, the SFC technique has resulted in successful separation more times than the HPLC methods, however, in many cases baseline separation was also attainable by the use of HPLC methods.

\section{I have examined the influence of temperature on the separation using cinchona alkaloid-based stationary phases.}

Examining the effect of temperature change on HPLC with identical column, I established that the studied components generally had the same chromatographic properties; therefore, the spatial structure of the selector determines the chromatographic behaviour. For each column, the selectivity decreased and the retention increased with increasing temperature, except for the $Z W I X(+)$ column, where the retention decreased.

In contrast to the HPLC data, I found that during the use of the SFC method, the density of the mobile phase determines the change of the retention, regardless of the spatial structure of the selector. By using a high density eluent, the retention always decreased with increasing temperature, while the use of a low density eluent increased retention. In case of the SFC method, just like in case of using the HPLC, the selectivity decreased every time when temperature was increased.

I calculated the apparent thermodynamic parameters of the chiral separation by using the van't Hoff equation. According to these data, the change of the temperature did not cause any change in the chiral recognition process and a solely enthalpy-driven resolution could be observed during both techniques. 


\section{I determined the effect of change in temperature on the separation using polysaccharide-based columns.}

For both HPLC and SFC methods, on every occasion the retention of the investigated compounds decreased with the increase in temperature using polysaccharide-based stationary phases. Selectivity changed inversely with temperature every time while using the HPLC method, and it usually changed during the use of SFC method as well. According to the apparent thermodynamic parameters calculated by the van't Hoff equation, the decreasing selectivity with increasing temperature is a characteristic of enthalpy-driven separation. In case of the SFC technique, the selectivity values varying in parallel with temperature is a characteristic of entropy-driven separation. According to these observations, the liquid carbon-dioxide can have a significant impact on the environment of the binding sites responsible for the chiral recognition. The mechanism of the separation did not change for either method as a result of the temperature change.

According to my measurements it can be stated, that the HPLC and SFC methods can be used successfully as complementary techniques for the enantioseparation of chiral compounds. 


\section{IRODALOMJEGYZÉK}

[1] Budău, M., Hancu, G., Rusu, A., Cârcu-Dobrin, M., Muntean, D. L., Adv. Pharm. Bull. 2017, 7, 495-500.

[2] Darmawan, D., Chiral Analysis. Elsevier, Cambridge 2006.

[3] Bentley, R., Perspect. Biol. Med. 1995, 38, 188-229.

[4] Schurig, V., Differentiation of Enantiomers I. 2013.

[5] Lough, W. J., Wainer, I. W., Chirality in Natural and Applied Science. 2003.

[6] Bijvoet, J. M., Peerdeman, A. F., Van Bommel, A. J., Nature 1951, 168, 271-272.

[7] Allenmark, S., Gawronski, J., Chirality 2008, 20, 606-608.

[8] Hoye, T. R., Jeffrey, C. S., Shao, F., Nat. Protoc. 2007, 2, 2451-2458.

[9] Flack, H. D., Bernardinelli, G., Chirality 2008, 20, 681-690.

[10] Calcaterra, A., D’Acquarica, I., J. Pharm. Biomed. Anal. 2018, 147, 323-340.

[11] Hollósi, M., Laczkó, I., Mayer, Z., A Sztereokémia És Kiroptikai Spektroszkópia Alapjai. Nemzeti Tankönyvkiadó Rt., Budapest 2004.

[12] Ernst, K. H., Phys. Status Solidi Basic Res. 2012, 249, 2057-2088.

[13] Polavarapu, P. L., Chiroptical Spectroscopy : Fundamentals and Applications. Taylor \& Francis, London 2017.

[14] Barron, L. D., Buckingham, A. D., Chem. Phys. Lett. 2010, 492, 199-213.

[15] Tarczay, G., Vass, E., Góbi, S., Magyarfalvi, G., Magy. Kémiai Folyóirat 2013, 119, 53-66.

[16] Polavarapu, P. L., Chirality 2002, 14, 768-781.

[17] Ding, S., Kolbanovskiy, A., Durandin, A., Crean, C., Shafirovich, V., Broyde, S., Geacintov, N. E., Chirality 2009, 21, 1-23.

[18] Poppe, L.; Nagy, J.; Hornyánszky, G., Sztereoszelektív Szintézisek. 2011.

[19] Francotte, E., Lindner, W., Chirality in Drug Research. 2006.

[20] Scriba, G. K. E., Chiral Separations. Methods and Protocols. 2009.

[21] Ilisz, I., Aranyi, A., Pataj, Z., Péter, A., J. Pharm. Biomed. Anal. 2012, 69, 28-41.

[22] Ilisz, I., Berkecz, R., Péter, A., J. Pharm. Biomed. Anal. 2008, 47, 1-15.

[23] Fekete, J., Kormány, R., Fekete, S. (Eds.), Modern Folyadékkromatográfia. KromKorm Kft., Budapest 2017.

[24] Dalgliesh, C. E., J. Chem. Soc. 1952, 3916-3922.

[25] Davankov, V. A., Chirality 1997, 9, 99-102.

[26] Bentley, R., Arch. Biochem. Biophys. 2003, 414, 1-12. 
[27] Lämmerhofer, M., J. Chromatogr. A 2010, 1217, 814-856.

[28] Pirkle, W. H., Pochapsky, T. C., Chem. Rev. 1989, 89, 347-362.

[29] Berthod, A., Anal. Chem. 2006, 78, 2093-2099.

[30] Ma, S., Shen, S., Lee, H., Eriksson, M., Zeng, X., Xu, J., Fandrick, K., Yee, N., Senanayake, C., Grinberg, N., J. Chromatogr. A 2009, 1216, 3784-3793.

[31] Ilisz, I., Bajtai, A., Lindner, W., Péter, A., J. Pharm. Biomed. Anal. 2018, 159, $127-$ 152.

[32] Berthod, A., Chiral Recognition in Separation Methods: Mechanisms and Applications. Springer-Verlag, Berlin 2010.

[33] Maier, N. M., Schefzick, S., Lombardo, G. M., Feliz, M., Rissanen, K., Lindner, W., Lipkowitz, K. B., J. Am. Chem. Soc. 2002, 124, 8611-8629.

[34] Bao, X., Snurr, R. Q., Broadbelt, L. J., Microporous Mesoporous Mater. 2013, 172, $44-50$.

[35] Scriba, G. K. E., TrAC Trends Anal. Chem. 2019, 120, 115639.

[36] Scriba, G. K. E., TrAC - Trends Anal. Chem. 2019, 119, 115628.

[37] Ilisz, I., Bajtai, A., Péter, A., Lindner, W., Methods in Molecular Biology. 2019, pp. 251-277.

[38] Hesse, G., Hagel, R., Chromatographia 1973, 6, 277-280.

[39] Ikai, T., Okamoto, Y., Chem. Rev. 2009, 109, 6077-6101.

[40] Chankvetadze, B., J. Chromatogr. A 2012, 1269, 26-51.

[41] Cavazzini, A., Pasti, L., Massi, A., Marchetti, N., Dondi, F., Anal. Chim. Acta 2011, 706, 205-222.

[42] Shen, J., Ikai, T., Okamoto, Y., J. Chromatogr. A 2014, 1363, 51-61.

[43] Beridze, N., Tsutskiridze, E., Takaishvili, N., Farkas, T., Chankvetadze, B., Chromatographia 2018, 81, 611-621.

[44] Maisuradze, M., Sheklashvili, G., Chokheli, A., Matarashvili, I., Gogatishvili, T., Farkas, T., Chankvetadze, B., J. Chromatogr. A 2019, 1602, 228-236.

[45] Okamoto, Y., Kawashima, M., Hatada, K., J. Chromatogr. A 1986, 363, 173-186.

[46] Yamamoto, C., Okamoto, Y., Bull. Chem. Soc. Jpn. 2004, 77, 227-257.

[47] Ye, Y. K., Bai, S., Vyas, S., Wirth, M. J., J. Phys. Chem. B 2007, 111, 1189-1198.

[48] Kasat, R. B., Wang, N. H. L., Franses, E. I., Biomacromolecules 2007, 8, 1676-1685.

[49] Kasat, R. B., Wee, S. Y., Loh, J. X., Wang, N. H. L., Franses, E. I., J. Chromatogr. B Anal. Technol. Biomed. Life Sci. 2008, 875, 81-92.

[50] McCalley, D. V., J. Chromatogr. A 2002, 967, 1-19. 
[51] Ramawat, K. G., Mérillon, J. M., Natural Products. Springer Berlin Heidelberg, Berlin, Heidelberg 2013.

[52] Achan, J., Talisuna, A. O., Erhart, A., Yeka, A., Tibenderana, J. K., Baliraine, F. N., Rosenthal, P. J., D’Alessandro, U., Malar. J. 2011, 10, 144.

[53] Stork, G., Niu, D., Fujimoto, A., Koft, E. R., Balkovec, J. M., Tata, J. R., Dake, G. R., J. Am. Chem. Soc. 2001, 123, 3239-3242.

[54] Rosini, C., Bertucci, C., Pini, D., Altemura, P., Salvadori, P., Tetrahedron Lett. 1985, 26, 3361-3364.

[55] Lämmerhofer, M., Lindner, W., J. Chromatogr. A 1996, 741, 33-48.

[56] Mandl, A., Nicoletti, L., Lämmerhofer, M., Lindner, W., J. Chromatogr. A 1999, 858, $1-11$.

[57] Péter, A., Grecsó, N., Tóth, G., Fülöp, F., Lindner, W., Ilisz, I., Isr. J. Chem. 2016, $56,1042-1051$.

[58] Calderón, C., Santi, C., Lämmerhofer, M., J. Sep. Sci. 2018, 41, 1224-1231.

[59] Hoffmann, C. V., Pell, R., Lämmerhofer, M., Lindner, W., Anal. Chem. 2008, 80, 8780-8789.

[60] Grecsó, N., Kohout, M., Carotti, A., Sardella, R., Natalini, B., Fülöp, F., Lindner, W., Péter, A., Ilisz, I., J. Pharm. Biomed. Anal. 2016, 124, 164-173.

[61] Grecsó, N., Forró, E., Fülöp, F., Péter, A., Ilisz, I., Lindner, W., J. Chromatogr. A 2016, 1467, 178-187.

[62] Carotti, A., Ianni, F., Sabatini, S., Di Michele, A., Sardella, R., Kaatz, G. W., Lindner, W., Cecchetti, V., Natalini, B., J. Pharm. Biomed. Anal. 2016, 129, 182-189.

[63] Orosz, T., Forró, E., Fülöp, F., Lindner, W., Ilisz, I., Péter, A., J. Chromatogr. A 2018, $1535,72-79$.

[64] Mimini, V., Ianni, F., Marini, F., Hettegger, H., Sardella, R., Lindner, W., Anal. Chim. Acta 2019, 1078, 212-220.

[65] West, C., Anal. Bioanal. Chem. 2018, 410, 6441-6457.

[66] West, C., Curr. Anal. Chem. 2013, 10, 99-120.

[67] Chester, T. L., Pinkston, J. D., Anal. Chem. 2004, 76, 4606-4613.

[68] Taguchi, K., Fukusaki, E., Bamba, T., J. Chromatogr. A 2014, 1362, 270-277.

[69] Taylor, L. T., J. Supercrit. Fluids 2009, 47, 566-573.

[70] Kalíková, K., Šlechtová, T., Vozka, J., Tesařová, E., Anal. Chim. Acta 2014, 821, 133.

[71] Guiochon, G., Tarafder, A., J. Chromatogr. A 2011, 1218, 1037-1114. 
[72] Ren-Qi, W., Teng-Teng, O., Siu-Choon, N., Weihua, T., TrAC - Trends Anal. Chem. 2012, 37, 83-100.

[73] Lesellier, E., West, C., J. Chromatogr. A 2015, 1382, 2-46.

[74] Saito, M., J. Biosci. Bioeng. 2013, 115, 590-599.

[75] Felletti, S., Ismail, O. H., De Luca, C., Costa, V., Gasparrini, F., Pasti, L., Marchetti, N., Cavazzini, A., Catani, M., Chromatographia 2019, 82, 65-75.

[76] Nováková, L., Grand-Guillaume Perrenoud, A., Francois, I., West, C., Lesellier, E., Guillarme, D., Anal. Chim. Acta 2014, 824, 18-35.

[77] Mourier, P. A., Eliot, E., Caude, M. H., Rosset, R. H., Tambute, A. G., Anal. Chem. 1985, 57, 2819-2823.

[78] Carrão, D. B., Perovani, I. S., de Albuquerque, N. C. P., de Oliveira, A. R. M., TrAC Trends Anal. Chem. 2020, 122, 115719.

[79] Siders, P. D., J. Chromatogr. A 2017, 1527, 97-104.

[80] Strubinger, J. R., Song, H., Parcher, J. F., Anal. Chem. 1991, 63, 104-108.

[81] West, C., Melin, J., Ansouri, H., Mengue Metogo, M., J. Chromatogr. A 2017, 1492, $136-143$.

[82] Pell, R., Lindner, W., J. Chromatogr. A 2012, 1245, 175-182.

[83] Andersson, M., Rodriguez-Meizoso, I., Turner, C., Hjort, K., Klintberg, L., J. Supercrit. Fluids 2018, 136, 95-101.

[84] Asnin, L. D., Stepanova, M. V., J. Sep. Sci. 2018, 41, 1319-1337.

[85] Chester, T. L., Coym, J. W., J. Chromatogr. A 2003, 1003, 101-111.

[86] Chankvetadze, B., TrAC - Trends Anal. Chem. 2020, 122, 115709.

[87] Sepsey, A., Horváth, É., Catani, M., Felinger, A., J. Chromatogr. A 2020, 1611, 460594.

[88] Marchetti, N., Cavazzini, A., Pasti, L., Dondi, F., J. Sep. Sci. 2009, 32, NA-NA.

[89] Leśko, M., Åsberg, D., Enmark, M., Samuelsson, J., Fornstedt, T., Kaczmarski, K., Chromatographia 2015, 78, 1293-1297.

[90] Samuelsson, J., Sajonz, P., Fornstedt, T., J. Chromatogr. A 2008, 1189, 19-31.

[91] Matarashvili, I., Kobidze, G., Chelidze, A., Dolidze, G., Beridze, N., Jibuti, G., Farkas, T., Chankvetadze, B., J. Chromatogr. A 2019, 1599, 172-179.

[92] Ilisz, I., Gecse, Z., Lajkó, G., Nonn, M., Fülöp, F., Lindner, W., Péter, A., J. Chromatogr. A 2015, 1384, 67-75.

[93] Panella, C., Ferretti, R., Casulli, A., Cirilli, R., J. Pharm. Anal. 2019, 9, 324-331.

[94] Blackwell, J. A., Stringham, R. W., Chromatographia 1997, 44, 521-528. 
[95] Bandini, M., Eichholzer, A., Angew. Chemie Int. Ed. 2009, 48, 9608-9644.

[96] Kumari, A., Singh, R. K., Bioorg. Chem. 2019, 89, 103021.

[97] Cao, R., Peng, W., Wang, Z., Xu, A., Curr. Med. Chem. 2007, 14, 479-500.

[98] Louis, E. D., Michalec, M., Jiang, W., Factor-Litvak, P., Zheng, W., Neurotoxicology 2014, 40, 52-56.

[99] Herraiz, T., Food Addit. Contam. 2004, 21, 1041-1050.

[100] Alomar, M. L., Rasse-Suriani, F. A. O., Ganuza, A., Cóceres, V. M., Cabrerizo, F. M., Angel, S. O., BMC Res. Notes 2013, 6, 193.

[101] de Carvalho, L. P., Venault, P., Potier, M.-C., Dodd, R. H., Brown, C., Chapouthier, G., Rossier, J., Eur. J. Pharmacol. 1986, 129, 323-332.

[102] de Meester, C., Mutat. Res. Genet. Toxicol. 1995, 339, 139-153.

[103] El Antri, A., Messouri, I., Bouktaib, M., El Alami, R., Bolte, M., El Bali, B., Lachkar, M., Molecules 2004, 9, 650-657.

[104] Forró, E., Schönstein, L., Fülöp, F., Tetrahedron: Asymmetry 2011, 22, 1255-1260.

[105] Antkiewicz-Michaluk, L., Wąsik, A., Michaluk, J., Neurotox. Res. 2014, 25, 1-12.

[106] Singh, I. P., Shah, P., Expert Opin. Ther. Pat. 2017, 27, 17-36.

[107] Huang, M.-H., Wu, S.-N., Wang, J.-P., Lin, C.-H., Lu, S.-I., Liao, L.-F., Shen, A.-Y., Drug Dev. Res. 2003, 60, 261-269.

[108] Holt, R. J., Drugs 1975, 9, 401-405.

[109] Sugahara, S., Fukuhara, K., Tokunaga, Y., Tsutsumi, S., Ueda, Y., Ono, M., Kurogi, K., Sakakibara, Y., Suiko, M., Liu, M.-C., Yasuda, S., J. Toxicol. Sci. 2018, 43, $213-$ 221.

[110] Fosgerau, K., Hoffmann, T., Drug Discov. Today 2015, 20, 122-128.

[111] Russo, A. F., Headache J. Head Face Pain 2017, 57, 37-46.

[112] Carpenter, G., Cohen, S., Trends Biochem. Sci. 1984, 9, 169-171.

[113] Mayer, M., Semetey, V., Gitlin, I., Yang, J., Whitesides, G. M., J. Am. Chem. Soc. 2008, 130, 1453-1465.

[114] Mora, L., Aristoy, M.-C., Toldrá, F., Encyclopedia of Food Chemistry. Elsevier 2019, pp. 381-389.

[115] Malandrino, N., Smith, R. J., in: Belfiore, A., LeRoith, D. (Eds.), Principles of Endocrinology and Hormone Action. Endocrinology. Springer, Cham, New York 2018, pp. 29-42.

[116] Ramos de Armas, R., González Díaz, H., Molina, R., Pérez González, M., Uriarte, E., Bioorg. Med. Chem. 2004, 12, 4815-4822. 
[117] Wilmore, D., Rombeau, J., J. Nutr. 2001, 131, 2447S-2602S.

[118] Santos, S., Torcato, I., Castanho, M. A. R. B., Biopolymers 2012, 98, 288-293.

[119] Lau, J. L., Dunn, M. K., Bioorganic Med. Chem. 2018, 26, 2700-2707.

[120] Bajtai, A., Lajkó, G., Szatmári, I., Fülöp, F., Lindner, W., Ilisz, I., Péter, A., J. Chromatogr. A 2018, 1563, 180-190.

[121] Ilisz, I., Péter, A., Lindner, W., TrAC - Trends Anal. Chem. 2016, 81, 11-22.

[122] Ilisz, I., Grecsó, N., Aranyi, A., Suchotin, P., Tymecka, D., Wilenska, B., Misicka, A., Fülöp, F., Lindner, W., Péter, A., J. Chromatogr. A 2014, 1334, 44-54.

[123] Ilisz, I., Gecse, Z., Pataj, Z., Fülöp, F., Tóth, G., Lindner, W., Péter, A., J. Chromatogr. A 2014, 1363, 169-177.

[124] Zhang, T., Holder, E., Franco, P., Lindner, W., J. Chromatogr. A 2014, 1363, 191199.

[125] Lajkó, G., Orosz, T., Grecsó, N., Fekete, B., Palkó, M., Fülöp, F., Lindner, W., Péter, A., Ilisz, I., Anal. Chim. Acta 2016, 921, 84-94.

[126] Sardella, R., Ianni, F., Lisanti, A., Marinozzi, M., Scorzoni, S., Natalini, B., Biomed. Chromatogr. 2014, 28, 159-167.

[127] Wang, T., Wenslow, R. M., J. Chromatogr. A 2003, 1015, 99-110.

[128] Grecsó, N., Ilisz, I., Gecse, Z., Schönstein, L., Fülöp, F., Péter, A., Biomed. Chromatogr. 2015, 29, 788-796.

[129] Lajkó, G., Orosz, T., Kiss, L., Forró, E., Fülöp, F., Péter, A., Ilisz, I., Biomed. Chromatogr. 2016, 30, 1441-1448.

[130] Raimbault, A., Ma, C. M. A., Ferri, M., Bäurer, S., Bonnet, P., Bourg, S., Lämmerhofer, M., West, C., J. Chromatogr. A 2020, 1612, 460689.

[131] Lajkó, G., Grecsó, N., Tóth, G., Fülöp, F., Lindner, W., Péter, A., Ilisz, I., Molecules 2016, 21, DOI: 10.3390/molecules21111579.

[132] Khater, S., Lozac'h, M.-A., Adam, I., Francotte, E., West, C., J. Chromatogr. A 2016, $1467,463-472$.

[133] Lipka, E., Dascalu, A.-E., Messara, Y., Tsutsqiridze, E., Farkas, T., Chankvetadze, B., J. Chromatogr. A 2019, 1585, 207-212.

[134] Grand-Guillaume Perrenoud, A., Boccard, J., Veuthey, J.-L., Guillarme, D., J. Chromatogr. A 2012, 1262, 205-213.

[135] Speybrouck, D., Doublet, C., Cardinael, P., Fiol-Petit, C., Corens, D., J. Chromatogr. A 2017, 1510, 89-99.

[136] Aranyi, A., Ilisz, I., Péter, A., Fülöp, F., West, C., J. Chromatogr. A 2015, 1387, 123-133. 
[137] Blackwell, J. A., Stringham, R. W., Weckwerth, J. D., Anal. Chem. 1997, 69, 409415.

[138] Lämmerhofer, M., Lindner, W., Adv. Chromatogr. 2008, 46, 1-107.

[139] Kopaciewicz, W., Rounds, M. A., Fausnaugh, J., Regnier, F. E., J. Chromatogr. A 1983, 266, 3-21.

[140] Geng, X., Regnier, F. E., Wang, Y., Chinese Sci. Bull. 2001, 46, 1763-1771.

[141] Pataj, Z., Ilisz, I., Gecse, Z., Szakonyi, Z., Fülöp, F., Lindner, W., Péter, A., J. Sep. Sci. 2014, 37, 1075-1082.

[142] Hoffmann, C. V., Reischl, R., Maier, N. M., Lämmerhofer, M., Lindner, W., J. Chromatogr. A 2009, 1216, 1157-1166.

[143] Scheiner, S., Kar, T., Pattanayak, J., J. Am. Chem. Soc. 2002, 124, 13257-13264.

[144] Czerwenka, C., Lämmerhofer, M., Maier, N. M., Rissanen, K., Lindner, W., Anal. Chem. 2002, 74, 5658-5666.

[145] Czerwenka, C., Lindner, W., Anal. Bioanal. Chem. 2005, 382, 599-638.

[146] Lin, F.-Y., MacKerell, A. D., J. Phys. Chem. B 2017, 121, 6813-6821.

[147] Ilisz, I., Grecsó, N., Misicka, A., Tymecka, D., Lázár, L., Lindner, W., Péter, A., Molecules 2014, 20, 70-87.

[148] Ilisz, I., Grecsó, N., Fülöp, F., Lindner, W., Péter, A., Anal. Bioanal. Chem. 2015, 407, 961-972.

[149] Lajkó, G., Grecsó, N., Megyesi, R., Forró, E., Fülöp, F., Wolrab, D., Lindner, W., Péter, A., Ilisz, I., J. Chromatogr. A 2016, 1467, 188-198.

[150] Åsberg, D., Enmark, M., Samuelsson, J., Fornstedt, T., J. Chromatogr. A 2014, 1374, 254-260. 


\section{KöZLEMÉNYEK LISTÁJA}

\subsection{Az értekezés alapját képező közlemények}

1. A. Bajtai, Gy. Lajkó, I. Szatmári, F. Fülöp, W. Lindner, I. Ilisz, A. Péter Dedicated comparisons of diverse polysaccharide- and zwitterionic Cinchona alkaloidbased chiral stationary phases probed with basic and ampholytic indole analogs in liquid and subcritical fluid chromatography mode

Journal of Chromatography A, 1563, (2018) 180-190

Impakt faktor $_{(2018)}$ : 3,858 (besorolás: Q1)

2. A. Bajtai, Gy. Lajkó, G. Németi, I. Szatmári, F. Fülöp, A. Péter, I. Ilisz

High-performance liquid chromatographic and subcritical fluid chromatographic separation of $\alpha$-arylated $\beta$-carboline, $\mathrm{N}$-alkylated tetrahydroisoquinolines and their bioisosteres on polysaccharide-based chiral stationary phases

Journal of Separation Science, 42, (2019) 2779-2787

Impakt faktor $_{(2019)}$ : 2,878 (besorolás: Q2)

3. A. Bajtai, I. Ilisz, D.H.O. Howan, G. K. Tóth, G.K.E. Scriba, W. Lindner, A. Péter Enantioselective resolution of biologically active dipeptide analogs by high-performance liquid chromatography applying Cinchona alkaloid-based ion-exchanger chiral stationary phases

Journal of Chromatography A, 1611, (2020) 1-12

Impakt faktor: 4,049

Impakt faktor(2019): 4,049 (besorolás: Q1)

Összesített impakt faktor: $\mathbf{1 0 , 7 8 5}$

\subsection{Az értekezés témájához kapcsolódó fel nem használt közlemények}

1. A. Bajtai, B. Fekete, M. Palkó, F. Fülöp, W. Lindner, M. Kohout, I. Ilisz, A. Péter Comparative study on the liquid chromatographic enantioseparation of cyclic $\beta$-amino acids and the related cyclic $\beta$-aminohydroxamic acids on Cinchona alkaloid-based zwitterionic chiral stationary phases

Journal of Separation Science, 41, (2017) 1216-1223

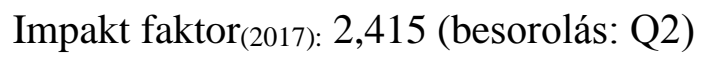


2. I. Ilisz, A. Bajtai, W. Lindner, A. Péter

Liquid chromatographic enantiomer separations applying chiral ion-exchangers based on Cinchona alkaloids

Journal of Pharmaceutical and Biomedical Analysis, 159, (2018) 127-152

Impakt faktor(2018): 2,983 (besorolás: Q1)

3. T. Orosz, A. Bajtai, T.M. Le, D. Tanács, Zs. Szakonyi, F. Fülöp, A. Péter, I. Ilisz

Chiral high-performance liquid and supercritical fluid chromatographic enantioseparations of limonene-based bicyclic aminoalcohols and aminodiols on polysaccharide-based chiral stationary phases

Biomedical Chromatography, 43, (2019) 1-11

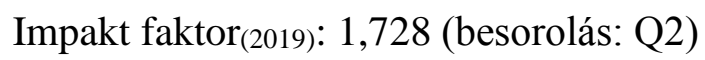

4. I. Ilisz, A. Bajtai, A. Péter, W. Lindner

Chiral Separations: Cinchona Alkaloid-Based Zwitterionic Chiral Stationary Phases Applied for Liquid Chromatographic Enantiomer Separations: An Overview

\section{Chiral Separations-Methods and Protocols}

Szerkesztő: G.K.E. Scriba, 2019, Humana Press, New York, NY, USA, Könyvfejezet

5. I. Ilisz, A. Bajtai, I. Szatmári, F. Fülöp, W. Lindner, A. Péter

Enantioseparation of $\beta$-carboline, tetrahydroisoquinoline and benzazepine analogues of pharmaceutical importance: utilization of chiral stationary phases based on polysaccharides and sulfonic acid modified Cinchona alkaloids in high-performance liquid and subcritical fluid chromatography

Journal of Chromatography A, 1615, (2020) 1-10

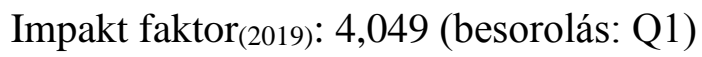

6. A. Bajtai, I. Ilisz, A. Péter, W. Lindner

Liquid chromatographic resolution of natural and racemic Cinchona alkaloid analogues using strong cation- and zwitterion ion-exchange type stationary phases. Qualitative evaluation of stationary phase characteristics and mobile phase effects on stereoselectivity and retention

Journal of Chromatography A, 1609, (2020) 1-13

Impakt faktor(2019): 4,049 (besorolás: Q1) 
7. A. Bajtai, I. Ilisz, R. Berkecz, F. Fülöp, W. Lindner, A. Péter

Polysaccharide-based chiral stationary phases as efficient tools for diastereo- and enantioseparation of natural and synthetic Cinchona alkaloid analogs

Journal of Pharmaceutical and Biomedical Analysis, 193, (2021) 113724

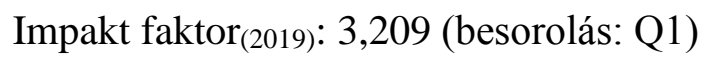

Összes közlemény impakt faktora: 29,218

\subsection{Előadások}

1. I. Ilisz, A. Péter, T. Orosz, A. Bajtai, Gy. Lajkó

Enantiomeric Separations by Ion Exchanger-Based Chiral Stationary Phases

$11^{\text {th }}$ Balaton Symposiumon on High-Performance Separation Methods

2017. szeptember 6-8. Siófok, Magyarország.

2. T. Orosz, E. Forró, F. Fülöp, W. Lindner, Gy. Lajkó, A. Bajtai, A. Péter, I. Ilisz

Enantioseparation of cyclic $\beta$-amino acids on ion-exchanger-based chiral stationary phases

$2^{\text {rd }}$ International Symposium on Analytical and Environmental Problems 2017. október 9-10. Szeged, Magyarország.

3. A. Bajtai, Gy. Lajkó, I. Szatmári, F. Fülöp, W. Lindner, I. Ilisz, A. Péter

Comparative study for the characterization of enantiorecognitions obtained by supercritical fluid chromatography and high-performance liquid chromatography Applications of Supercritical Fluids

2018. május 17. Budapest, Magyarország.

4. A. Bajtai, D. Tanács, T. Orosz, Gy. Lajkó, I. Szatmári, F. Fülöp, W. Lindner, I. Ilisz, A. Péter

Enantiomer separation of chiral tetrahydroisoquinoline analogs by supercritical fluid chromatography and high-performance liquide chromatography

$2^{\text {th }}$ International Symposium on Analytical and Environmental Problems

2018. október 9. Szeged, Magyarország.

5. I. Ilisz, A. Bajtai, A. Péter

Királis szelektorok alkalmazási lehetőségei enantiomerek elválasztására a nagyhatékonyságú folyadékkromatográfiában

Elválasztástudományi vándorgyülés 2018

2018. november 8-10. Tapolca, Magyarország. 
6. A. Bajtai, D. Tanács, E. Forró, F. Fülöp, W. Lindner, A. Péter, I. Ilisz

High-performance liquid chromatographic enantioseparation of some amino compounds with pharmaceutical relevance on ion-exchanger-based chiral stationary phases

26 $^{\text {th }}$ International Symposium on Analytical and Environmental Problems

2020. november 23. Szeged, Magyarország.

\subsection{Poszterek}

1. I. Ilisz, A. Bajtai, Zs. Szakonyi, F. Fülöp, D.W. Armstrong, A. Péter

HPLC enantioseparation of carbocyclic $\beta$-amino acids possessing limonene skeleton on macrocyclic glycopeptide-based chiral stationary phases

$4^{\text {th }}$ International Symposium on High-Performance Liquid Phase Separations and Related Techniques

2017. június 18-22. Prága, Csehország.

2. A. Bajtai, B. Fekete, M. Palkó, F. Fülöp, W. Lindner, A. Péter, I. Ilisz

Application of Cinchona alkaloid-based chiral zwitterionic stationary phases for the enantioseparation of cyclic $\beta$-aminohydroxamic acids

$11^{\text {th }}$ Balaton Symposium on High-Performance Separation Methods

2017. szeptember 6-8. Siófok, Magyarország.

3. T. Orosz, G. Németi, A. Bajtai, Zs. Szakonyi, F. Fülöp, I. Ilisz, A. Péter

Chiral high-performance liquide and supercritical fluid chromatographic enantioseparations of limonene-based vicyclic aminoalcohols and aminodiols on polysaccharide chiral stationary phases

$2^{\text {th }}$ International Symposium on Analytical and Environmental Problems

2018. október 8-9. Szeged, Magyarország.

4. A. Bajtai, Gy. Lajkó, D. Tanács, I. Szatmári, F. Fülöp, W. Lindner, I. Ilisz, A. Péter Királis elválasztási mechanizmusok vizsgálata poliszacharid és ikerionos állófázisokon Elválasztástudományi vándorgyülés 2018

2018. november 8-10. Tapolca, Magyarország.

5. T. Orosz, A. Bajtai, G. Németi, Zs. Szakonyi, F. Fülöp, I. Ilisz, A. Péter

Új, limonén alapú biciklusos aminoalkoholok és aminodiolok elválasztása királis folyadékkromatográfiával és szuperkritikus fluid kromatográfiával Elválasztástudományi vándorgyülés 2018

2018. november 8-10. Tapolca, Magyarország. 
6. I. Ilisz, A. Bajtai, I. Szatmári, F. Fülöp, W. Lindner, A. Péter

Chiral high-performance liquid and subctirical fluid chromatography study of some pharmaceutically important $\beta$-carboline tetrahydroisoquinoline and benzazepine analogs $4^{\text {th }}$ International Symposium on High-Performance Liquid Phase Separations and Related Techniques

2019. június 16-20. Milánó, Olaszország.

7. A. Péter, A. Bajtai, G. Tóth, W. Lindner, G.K.E. Scriba, I. Ilisz, Comparative study of enantioseparations of natural and unnatural dipeptides on Cinchona alkaloid based chiral stationary phases

$4^{\text {th }}$ International Symposium on High-Performance Liquid Phase Separations and Related Techniques

2019. június 16-20. Milánó, Olaszország.

8. A. Bajtai, A. Péter, W. Lindner, I. Ilisz

Application of Polysaccharide-based Chiral Stationary Phases for the Enantioseparation of Natural and Synthetic Cinchona Alkaloid Analogues

$12^{\text {th }}$ Balaton Symposium on High-Performance Separation Methods

2019. szeptember 11-13. Siófok, Magyarország. 


\section{KöSZÖNETNYILVÁNÍTÁS}

Ezúton szeretném hálás köszönetemet kifejezni témavezetőmnek, Prof. Dr. Ilisz István intézetvezető egyetemi tanárnak, hogy lehetőséget biztosított a Gyógyszeranalitikai Intézetben doktori munkám elvégzésére. Szakmai segítsége, támogatása és inspirálása meghatározta az elmúlt négy évemet. Közös munkánk során példamutatása nemcsak szakmailag, hanem emberileg is követendő mintaként állt elöttem.

Hálásan köszönöm Prof. Dr. Péter Antal emeritus professzornak, hogy bármikor fordulhattam hozzá segítségért és fáradtságot nem ismerve mindig a rendelkezésemre állt. Iránymutatása és hasznos tanácsai mindig új lendületet adtak a nehézségeken való túl jutáshoz.

Köszönettel tartozom Prof. Dr. Fülöp Ferenc akadémikusnak, Dr. Szatmári István egyetemi docensnek és munkatársaiknak, hogy kiváló munkájuk eredményeivel az én kutatásom előrejutását is segítették.

Köszönöm Prof. Dr. Galbács Gábor tanszékvezető egyetemi tanárnak, hogy a Szervetlen és Analitikai Kémiai Tanszéken kezdhettem meg kutatómunkám és biztosította a zavartalan munkavégzést.

Köszönöm egykori és jelenlegi munkatársaimnak Lajkó Gyulának, Dr. Orosz Tímeának, illetve Tanács Dániel és Németi Gábor PhD hallgatóknak a szakmai közremüködést és bíztatást.

Hálával gondolok a Gyógyszeranalitikai Intézet valamennyi dolgozójára a munkám során nyújtott segítségért és szakmai támogatásért.

Megtiszteltetés volt Veletek a közös munka.

Végezetül szeretném kifejezni mélységes hálámat családom és párom iránt, akik mindig mellettem álltak és segítették tanulmányaimat. Támogatásuk minden teher elviselését könnyebbé tette, amelyet sosem feledek. 


\section{FÜGGELÉK}

$$
-2 ;--1-2 ;-16
$$
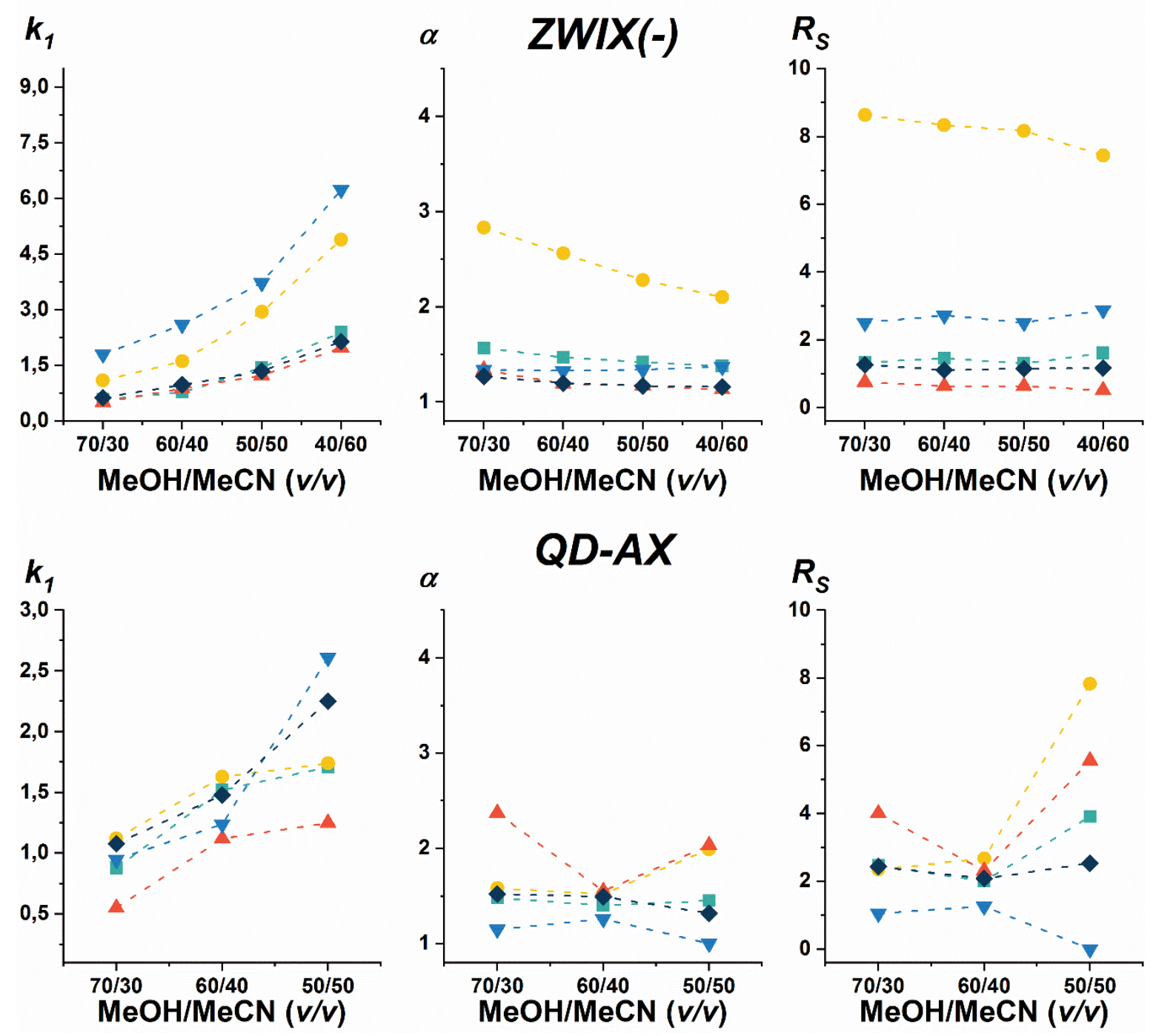

F1 ábra A kromatográfiás paraméterek változása kinidin alapú állófázisok esetén

Kromatográfiás körülmények: kolonna, ZWIX(-) és $Q D-A X$; mozgófázis, ZWIX(-) esetén MeOH/MeCN (70/30, 60/40, 50/50, 40/60 v/v) és DEA (25 mM) és FA (50 mM), $Q D-A X$ esetén MeOH/MeCN (50/50, 40/60, $30 / 70 v / v)$ és DEA (25 mM) és FA (50 mM); áramlási sebesség, 0,6 ml perc ${ }^{-1}$; detektálás, $230 \mathrm{~nm}$; hőmérséklet, $25^{\circ} \mathrm{C}$. 


\begin{tabular}{|c|c|c|c|c|c|c|c|c|c|c|}
\hline & $N_{l} / m$ & $N_{2} / m$ & $N_{1} / m$ & $N_{2} / m$ & $N_{1} / m$ & $N_{2} / m$ & $N_{1} / m$ & $N_{2} / m$ & $N_{1} / m$ & $N_{2} / m$ \\
\hline & \multicolumn{10}{|c|}{$Z W I X(+)$} \\
\hline $\begin{array}{c}\text { Eluens } \\
\mathrm{MeOH} / \mathrm{MeCN} \\
\end{array}$ & \multicolumn{2}{|c|}{2} & \multicolumn{2}{|c|}{6} & \multicolumn{2}{|c|}{9} & \multicolumn{2}{|c|}{11} & \multicolumn{2}{|c|}{16} \\
\hline $70 / 30$ & 17813 & 14773 & 19893 & 14093 & 19133 & 17700 & 22913 & 19800 & 14647 & 13867 \\
\hline $60 / 40$ & 18300 & 15547 & 22222 & 16239 & 17587 & 14596 & 19364 & 13286 & 21369 & 17123 \\
\hline $50 / 50$ & 19140 & 14880 & 23207 & 17407 & 15447 & 12640 & 17993 & 10367 & 22707 & 13873 \\
\hline \multirow[t]{2}{*}{$40 / 60$} & 10653 & 8087 & 26147 & 18114 & 10400 & 7533 & 8253 & 7427 & 19447 & 12547 \\
\hline & \multicolumn{10}{|c|}{$Z W I X(-)$} \\
\hline $70 / 30$ & 16513 & 12927 & 24147 & 14947 & 7367 & 6080 & 21047 & 16000 & 11427 & 10220 \\
\hline $60 / 40$ & 19020 & 12707 & 26117 & 12947 & 12387 & 9393 & 21563 & 15812 & 8987 & 6593 \\
\hline $50 / 50$ & 24267 & 14680 & 30560 & 13133 & 12680 & 10320 & 18498 & 15104 & 9900 & 7920 \\
\hline \multirow[t]{2}{*}{$40 / 60$} & 28053 & 18143 & 29060 & 13678 & 18727 & 9627 & 13080 & 12453 & 11367 & 8253 \\
\hline & \multicolumn{10}{|c|}{$Q N-A X$} \\
\hline $50 / 50$ & 20713 & 14380 & 13007 & - & 22440 & 21213 & 24907 & 9940 & 12187 & 10147 \\
\hline $40 / 60$ & 21691 & 17360 & 11487 & - & 27800 & 23145 & 23118 & 21093 & 18540 & 16258 \\
\hline \multirow[t]{2}{*}{$30 / 70$} & 14920 & 9173 & 11227 & - & 29780 & 26400 & 18807 & 16327 & 22320 & 15607 \\
\hline & \multicolumn{10}{|c|}{$Q D-A X$} \\
\hline $50 / 50$ & 17727 & 14593 & 17320 & 11700 & 27293 & 25473 & 16540 & 15620 & 17907 & 15400 \\
\hline $40 / 60$ & 15780 & 13413 & 14360 & 13620 & 26873 & 21920 & 12560 & 10767 & 11633 & 16253 \\
\hline $30 / 70$ & 12867 & 9493 & 9740 & - & 9327 & 7647 & 9660 & 9220 & 17820 & 14360 \\
\hline
\end{tabular}

F1 táblázat $\mathrm{Az}$ elméleti tányérszámok változása a $\mathrm{MeOH} / \mathrm{MeCN}$ mozgófázis összetétel függvényében cinkóna alkaloid alapú állófázisok esetén

Kromatográfiás körülmények: kolonna, $Z W I X(+), Z W I X(-), Q N-A X$ és $Q D-A X$; mozgófázis, $Z W I X(+)$ és $Z W I X(-)$ esetén $\mathrm{MeOH} / \mathrm{MeCN}$ (70/30, 60/40, 50/50, 40/60 v/v) és DEA (25 mM) és FA (50 mM), $Q N$-AX és $Q D$-AX esetén $\mathrm{MeOH} / \mathrm{MeCN}(50 / 50,40 / 60,30 / 70 v / v)$ és DEA ( $25 \mathrm{mM})$ és FA (50 mM); áramlási sebesség, $0,6 \mathrm{ml}$ perc ${ }^{-1}$; detektálás, $230 \mathrm{~nm}$; hőmérséklet, $25^{\circ} \mathrm{C}$. 
$---2 ;--\nabla--6 ;---9$;
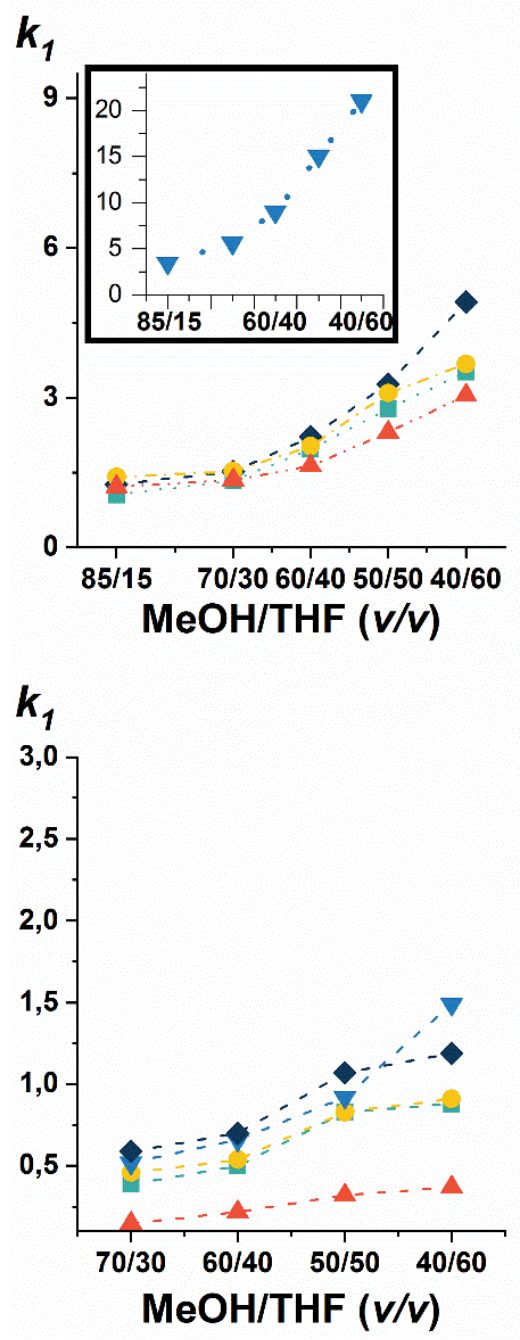
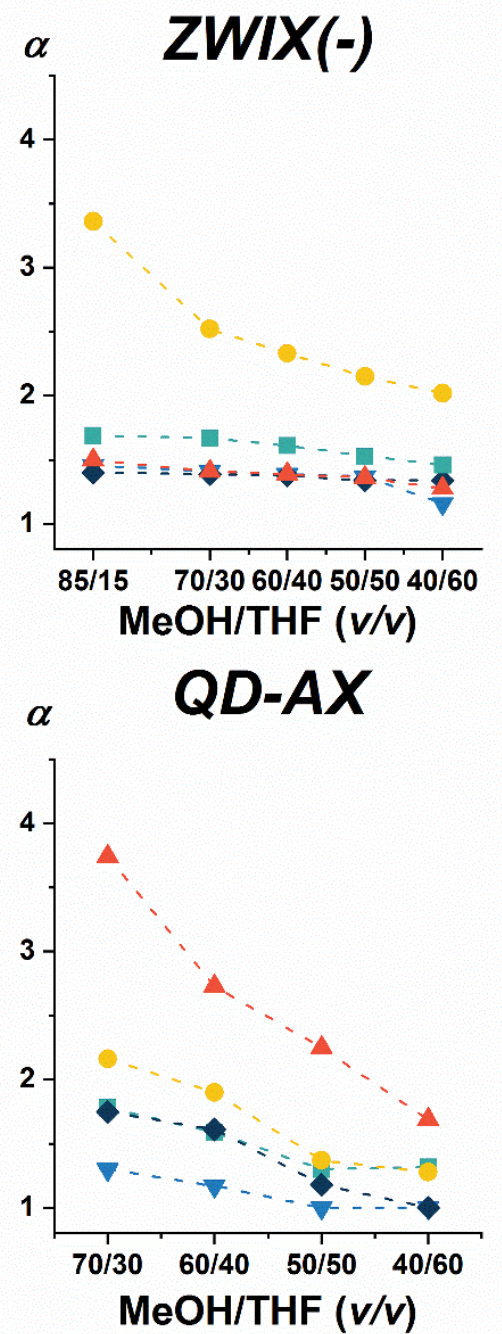

$11 ;--16$
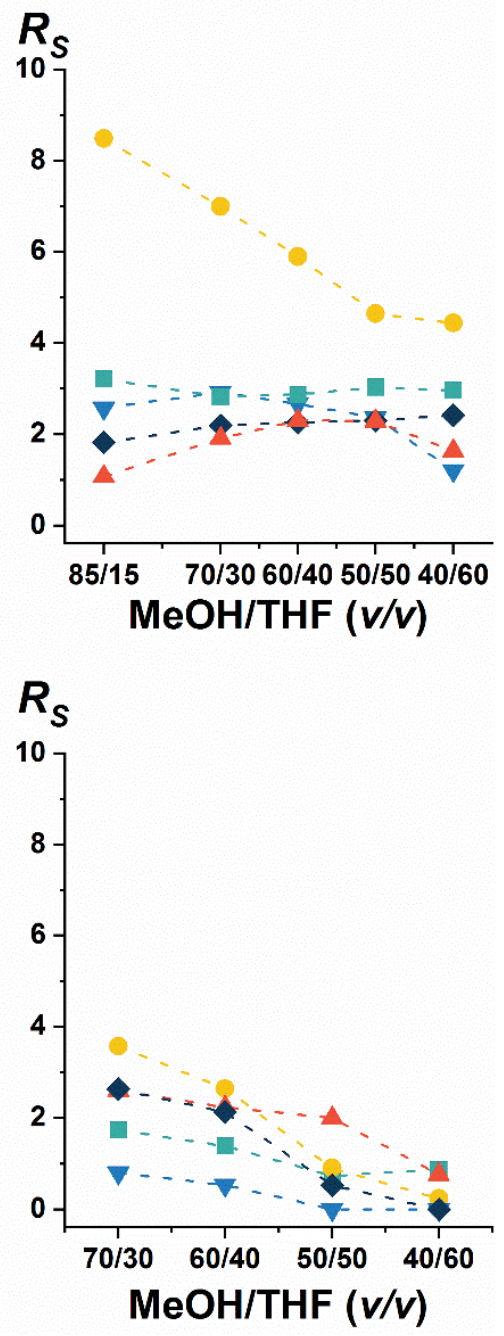

F2 ábra A THF tartalom hatása a kromatográfiás paraméterek változására

Kromatográfiás körülmények: kolonna, ZWIX(-) és $Q D$-AX; mozgófázis, ZWIX(-) esetén MeOH/THF (85/15, $70 / 30,60 / 40,50 / 50,40 / 60 v / v)$ és DEA (25 mM) és FA (50 mM), $Q D$-AX esetén MeOH/THF (70/30, 60/40, 50/50, 40/60 v/v) és DEA $(25 \mathrm{mM})$ és FA $(50 \mathrm{mM})$; áramlási sebesség, $0,6 \mathrm{ml}_{\text {perc }}{ }^{-1}$; detektálás, $230 \mathrm{~nm}$; hömérséklet, $25^{\circ} \mathrm{C}$. 


\begin{tabular}{|c|c|c|c|c|c|c|c|c|c|c|}
\hline & $N_{1} / m$ & $N_{2} / m$ & $N_{l} / m$ & $N_{2} / m$ & $N_{I} / m$ & $N_{2} / m$ & $N_{l} / m$ & $N_{2} / m$ & $N_{I} / m$ & $N_{2} / m$ \\
\hline & \multicolumn{10}{|c|}{$Z W I X(+)$} \\
\hline $\begin{array}{c}\text { Eluens } \\
\mathrm{MeOH} / \mathrm{THF}\end{array}$ & \multicolumn{2}{|c|}{2} & \multicolumn{2}{|c|}{6} & \multicolumn{2}{|c|}{9} & \multicolumn{2}{|c|}{11} & \multicolumn{2}{|c|}{16} \\
\hline $85 / 15$ & 27160 & 18960 & 24300 & 20169 & 30333 & 21767 & 30680 & 21433 & 21317 & 9860 \\
\hline $70 / 30$ & 27880 & 18713 & 25691 & 22169 & 27880 & 18713 & 20007 & 15353 & 18933 & 11861 \\
\hline $60 / 40$ & 25027 & 17644 & 22207 & 20327 & 23560 & 16153 & 14073 & 9800 & 13733 & 9900 \\
\hline $50 / 50$ & 20780 & 10920 & 16873 & 13493 & 21720 & 15827 & 10087 & 8633 & 12227 & 8273 \\
\hline \multirow[t]{2}{*}{$40 / 60$} & 17900 & 9473 & 10040 & 6760 & 18340 & 12227 & 9813 & 7793 & 11440 & 6720 \\
\hline & \multicolumn{10}{|c|}{$Z W I X(-)$} \\
\hline $85 / 15$ & 12211 & 11293 & 16284 & 10522 & 16233 & 14113 & 15380 & 12927 & 12967 & 8213 \\
\hline $70 / 30$ & 12933 & 12540 & 16927 & 8467 & 15433 & 15100 & 13907 & 12947 & 13447 & 10307 \\
\hline $60 / 40$ & 13587 & 12511 & 16260 & 8100 & 15364 & 14822 & 13127 & 12052 & 15691 & 12420 \\
\hline $50 / 50$ & 12933 & 12540 & 13393 & 8453 & 16234 & 16647 & 11391 & 10900 & 15120 & 13860 \\
\hline \multirow[t]{2}{*}{$40 / 60$} & 12147 & 8340 & 13447 & 7593 & 15787 & 15387 & 10847 & 9453 & 12107 & 10211 \\
\hline & \multicolumn{10}{|c|}{$Q N-A X$} \\
\hline $60 / 40$ & 12140 & 10253 & 5420 & 4160 & 8113 & 7553 & 19880 & 9107 & 7547 & 4113 \\
\hline $50 / 50$ & 8207 & 6540 & 4340 & 2793 & 7933 & 5607 & 17260 & 9473 & 10568 & 8561 \\
\hline $40 / 60$ & 7827 & 5573 & 3540 & - & 5447 & 3593 & 16480 & 8233 & 9267 & 7207 \\
\hline \multirow[t]{2}{*}{$30 / 70$} & 4633 & - & 3527 & - & 4207 & - & 12100 & 5593 & 6213 & 4180 \\
\hline & \multicolumn{10}{|c|}{$Q D-A X$} \\
\hline $60 / 40$ & 14581 & 13793 & 7913 & 7673 & 9947 & 8673 & 13053 & 9900 & 13527 & 13387 \\
\hline $50 / 50$ & 12553 & 10927 & 6927 & 5420 & 9287 & 7880 & 11500 & 6553 & 13293 & 9540 \\
\hline $40 / 60$ & 7080 & 5380 & 4020 & - & 6193 & 5247 & 8593 & 7560 & 11300 & 7260 \\
\hline $30 / 70$ & 6207 & - & 3227 & - & 6820 & 5407 & 7580 & 5393 & 11553 & 6793 \\
\hline
\end{tabular}

F2 táblázat $\mathrm{Az}$ elméleti tányérszámok változása a $\mathrm{MeOH} / \mathrm{THF}$ mozgófázis összetétel függvényében cinkóna alkaloid alapú állófázisok esetén

Kromatográfiás körülmények: kolonna, $Z W I X(+), Z W I X(-), Q N-A X$ és $Q D-A X$; mozgófázis, $Z W I X(+)$ és $Z W I X(-)$ esetén MeOH/THF (85/15, 70/30, 60/40, 50/50, 40/60 v/v) és DEA (25 mM) és FA (50 mM), QN-AX és $Q D-A X$ esetén MeOH/THF (70/30, 60/40, 50/50, 40/60 v/v) és DEA ( $25 \mathrm{mM})$ és FA (50 mM); áramlási sebesség, $0,6 \mathrm{ml}$ perc ${ }^{-1}$; detektálás, $230 \mathrm{~nm}$, hömérséklet, $25^{\circ} \mathrm{C}$. 

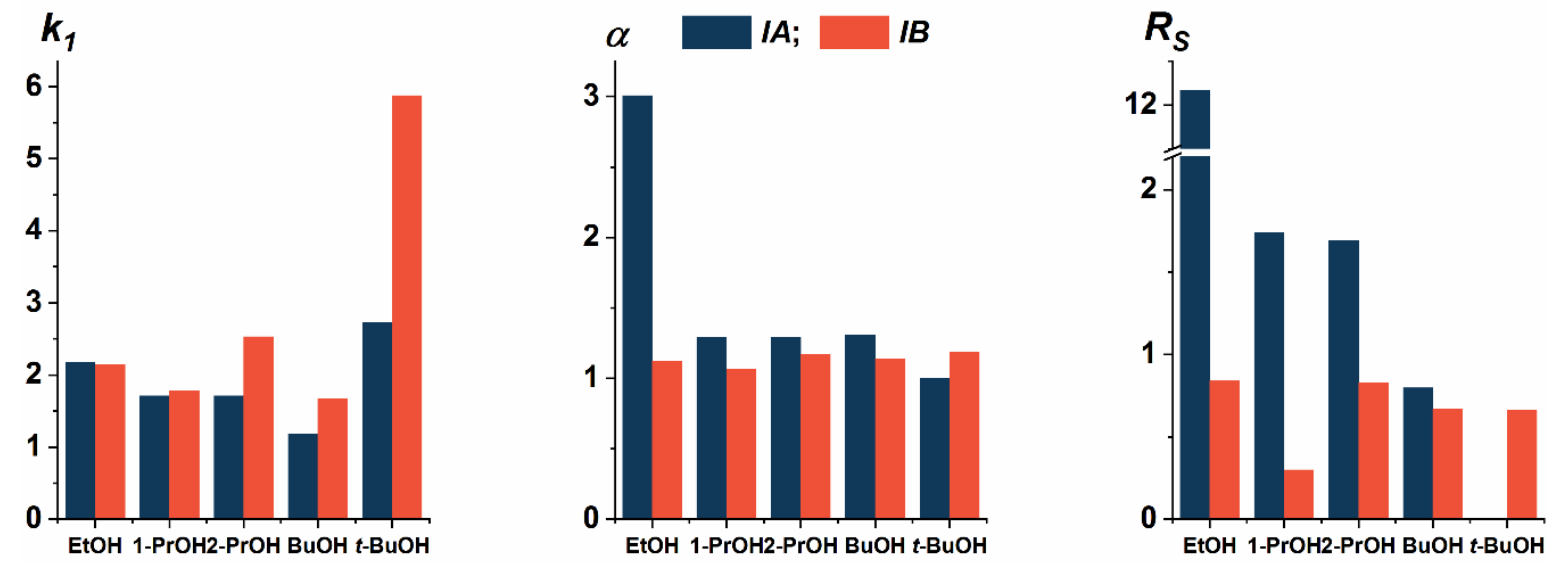

F3 ábra Az alkohol anyagi minőségének hatása a kromatográfiás paraméterekre a 21 vegyület esetén

Kromatográfiás körülmények: kolonna, IA, IB; mozgófázis, $n$-hexán/alkohol/DEA (70/30/0,1 v/v/v); áramlási sebesség, 1,0 ml perc ${ }^{-1}$; detektálás, 215-250 nm; hőmérséklet, szobahőmérséklet.
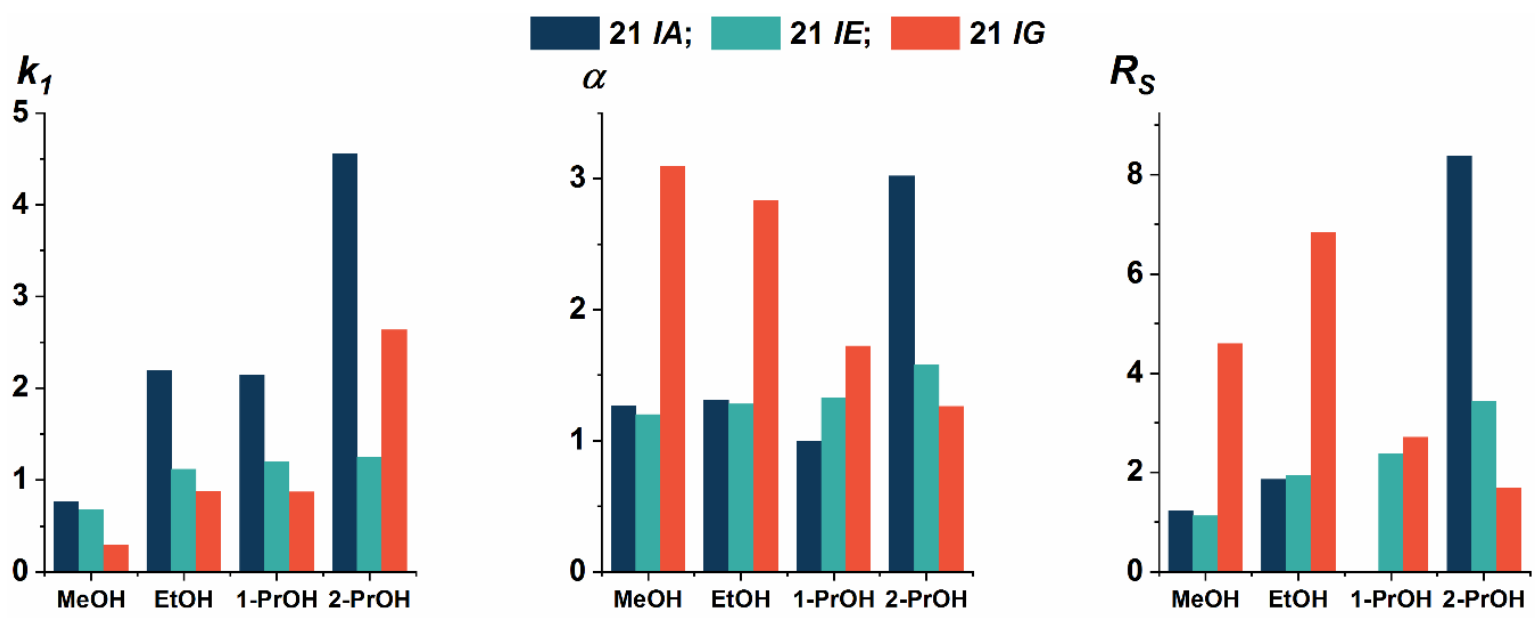

F4 ábra Az SFC mozgófázist alkotó alkohol anyagi minőségének hatása az elválasztásra Kromatográfiás körülmények: kolonna, $I A, I E, I G$; mozgófázis, $\mathrm{MeOH} / \mathrm{CO}_{2}(50 / 50 v / v)$ és DEA $(20 \mathrm{mM})$; áramlási sebesség, $2,0 \mathrm{ml}$ perc ${ }^{-1}$; detektálás, $215-250 \mathrm{~nm}$; hömérséklet, $40^{\circ} \mathrm{C}$, ellennyomás 150 bar. 

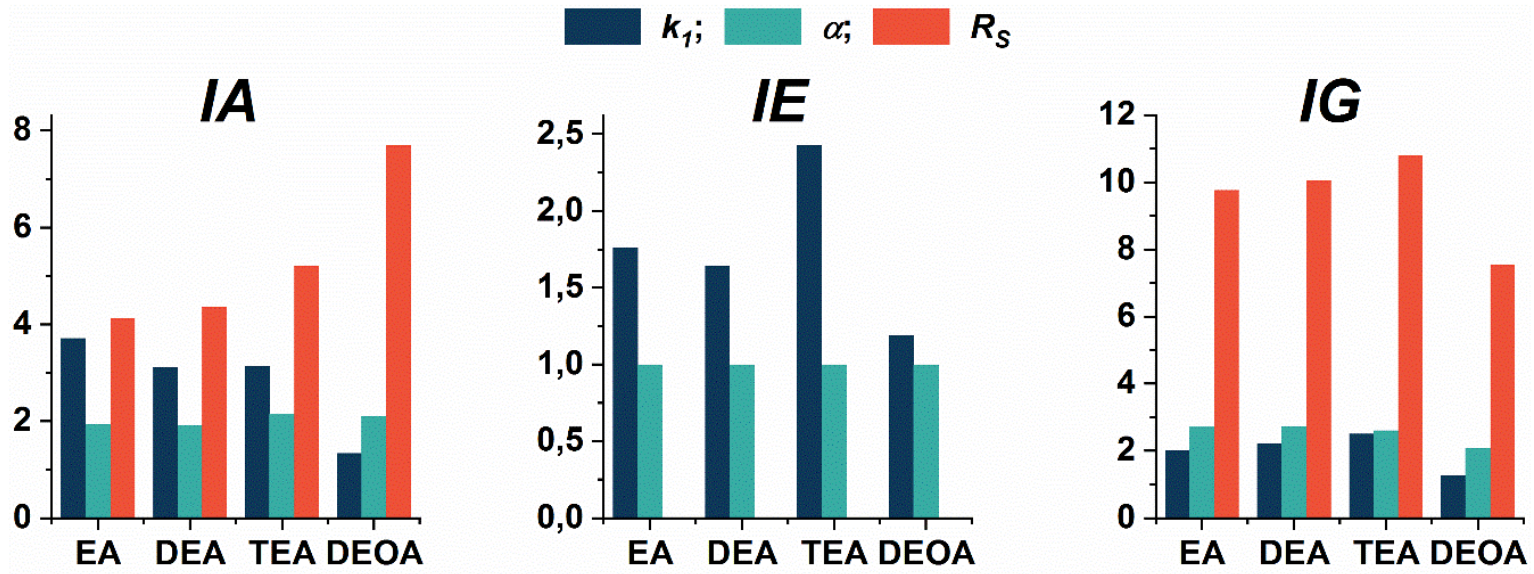

F5 ábra $\mathrm{Az}$ SFC mozgófázishoz adott alkil-aminok anyagi minőségének hatása az elválasztásra 23 vegyület esetén

Kromatográfiás körülmények: kolonna, $I A, I E, I G$; mozgófázis, $\mathrm{MeOH} / \mathrm{CO}_{2}(50 / 50 v / v)$ és EA vagy DEA vagy TEA vagy DEOA (20 mM); áramlási sebesség, $2,0 \mathrm{ml}$ perc ${ }^{-1}$; detektálás, $215-250 \mathrm{~nm}$; hömérséklet, $40{ }^{\circ} \mathrm{C}$, ellennyomás 150 bar.
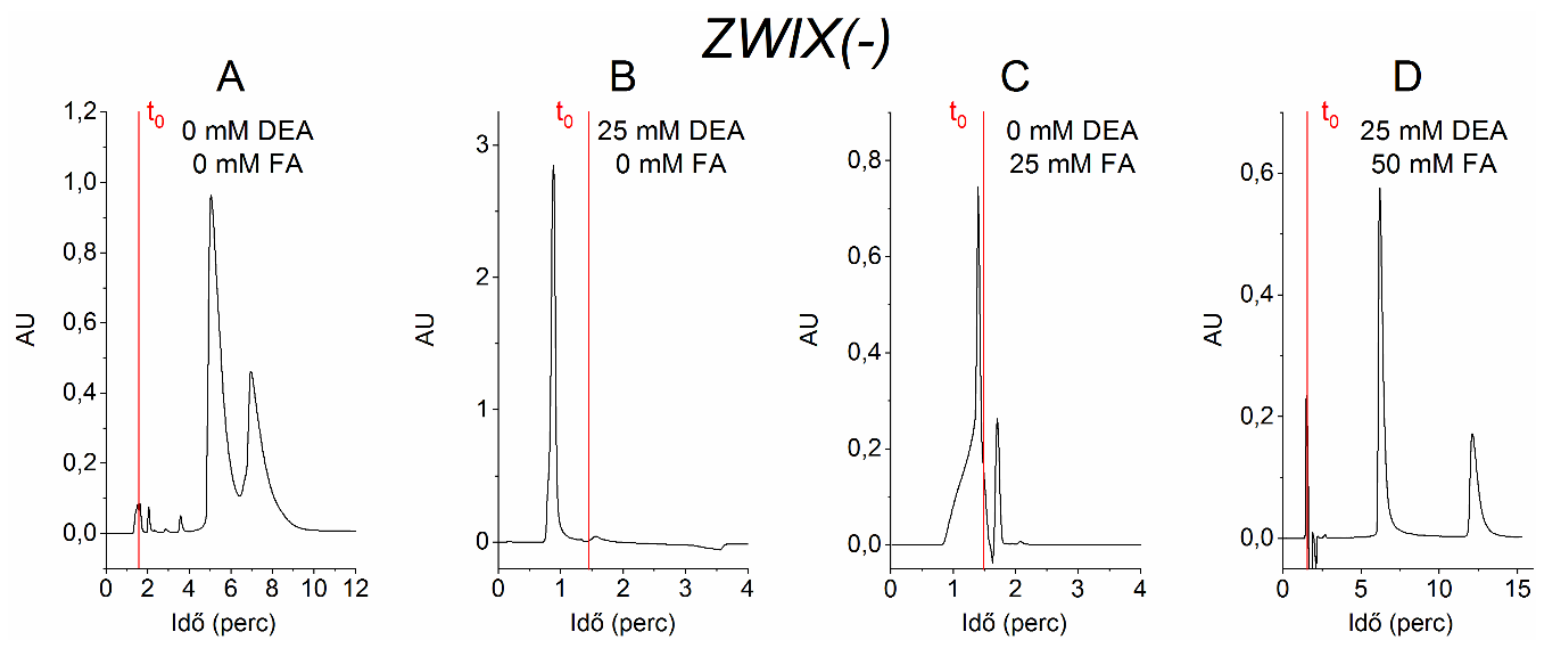

F6 ábra A mozgófázishoz adott sav, illetve bázis hatása az elválasztásra

Kromatográfiás körülmények: kolonna, ZWIX(-); mozgófázis, MeOH/MeCN (50/50 v/v) és DEA (0 vagy 25 $\mathrm{mM}$ ) és FA (0 vagy 25 vagy $50 \mathrm{mM}$ ); áramlási sebesség, $0,6 \mathrm{ml} \mathrm{perc}^{-1}$; detektálás, 221-280 nm; hömérséklet, $25^{\circ} \mathrm{C}$. 


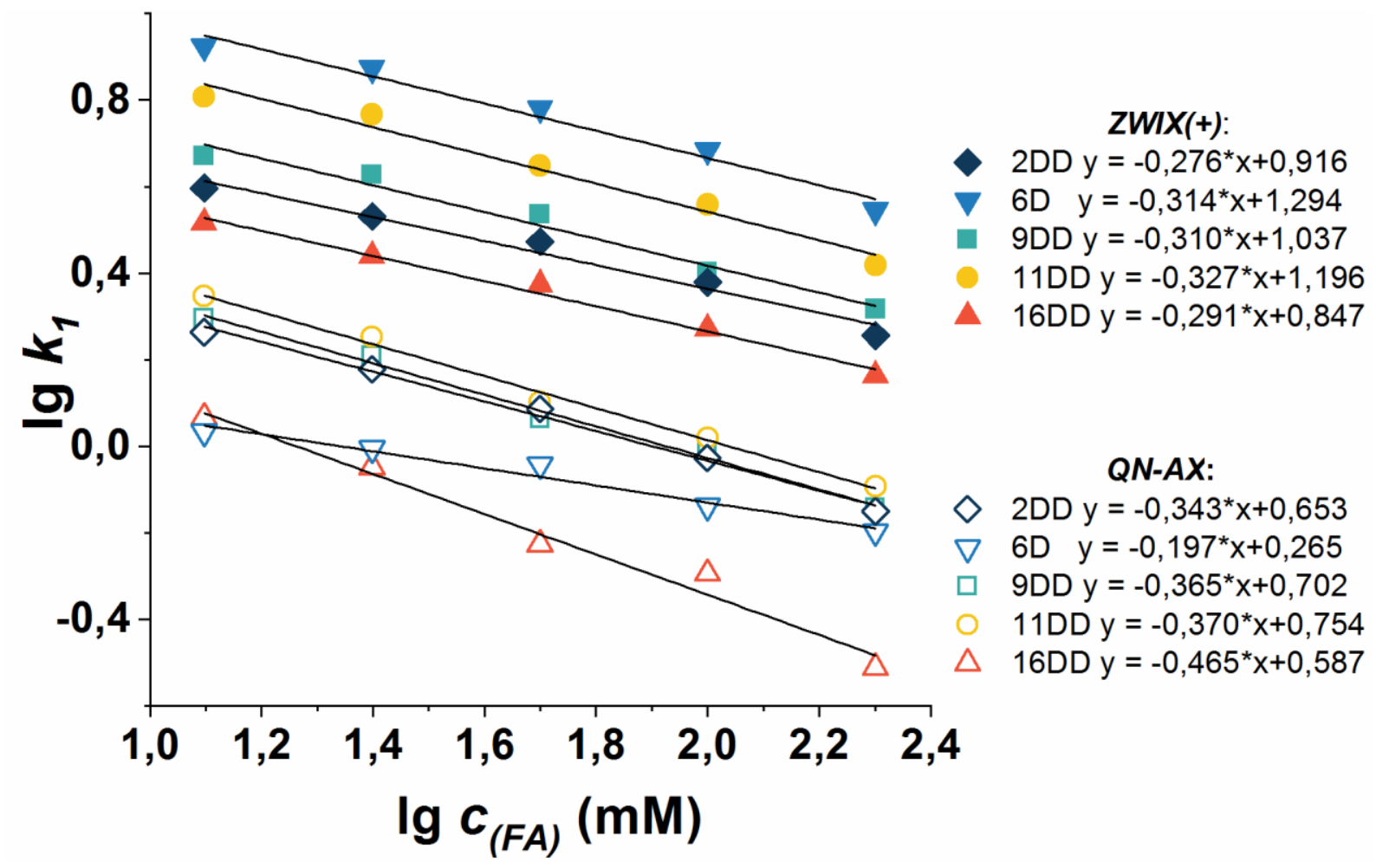

F7 ábra Az eluenshez adott sav és bázis mennyiségének hatása az elválasztásra

Kromatográfiás körülmények: kolonna, $Z W I X(+)$ és $Q N-A X$; mozgófázis, $\mathrm{MeOH} / \mathrm{MeCN}(50 / 50 v / v)$ és DEA/FA $(6,25 / 12,5,12,5 / 25,25 / 50,50 / 100$ és 100/200 $(\mathrm{mM} / \mathrm{mM}))$; áramlási sebesség, 0,6 $\mathrm{ml} \mathrm{perc}^{-1}$; detektálás, $221-280 \mathrm{~nm}$; hömérséklet, $25^{\circ} \mathrm{C}$.

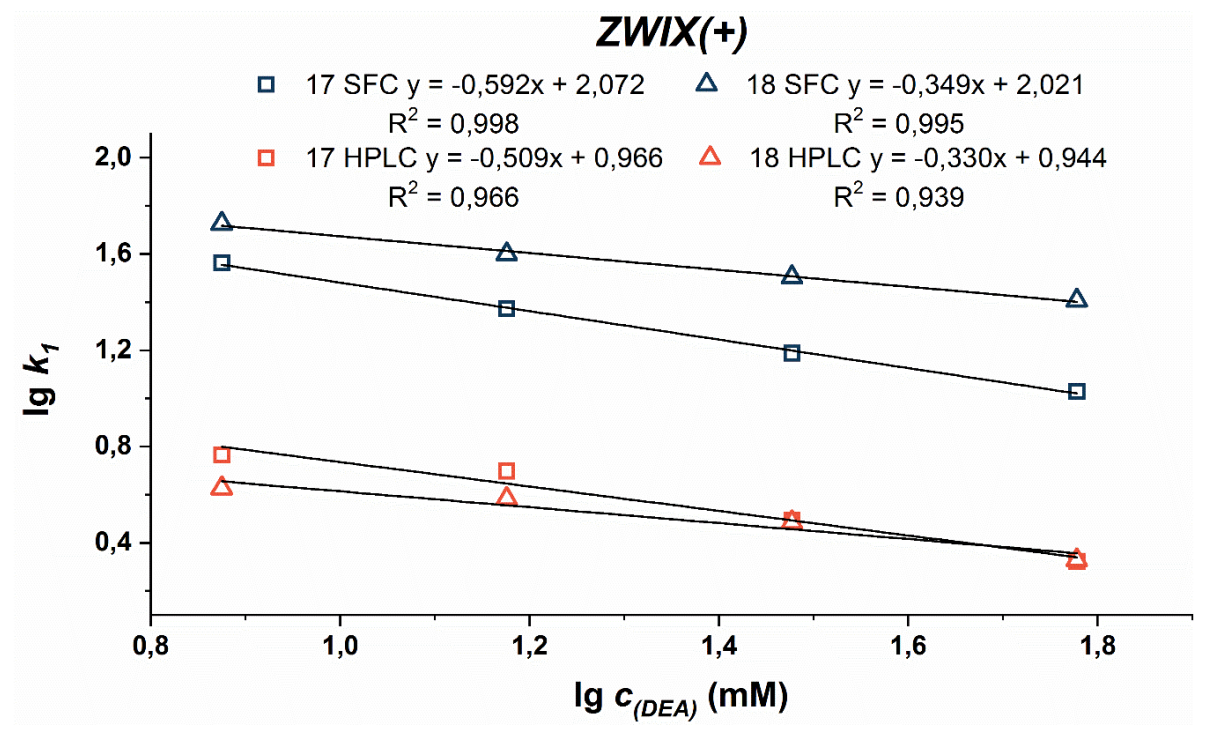

F8 ábra Az SFC és a HPLC mozgófázishoz adott sav és bázis hatásának összehasonlítása Kromatográfiás körülmények: kolonna, $Z W I X(+)$; mozgófázis, MeOH/MeCN (30/70 v/v) és DEA/FA (7,5/15, $15 / 30,30 / 60$ és 60/120 $(\mathrm{mM} / \mathrm{mM}))$ vagy $\mathrm{MeOH} / \mathrm{CO}_{2}(30 / 70 v / v)$ és DEA/FA $(7,5 / 15,15 / 30,30 / 60$ és 60/120 $(\mathrm{mM} / \mathrm{mM})$ ); áramlási sebesség, HPLC, 0,6 ml perc ${ }^{-1}$, SFC $2 \mathrm{ml}_{\text {perc }}^{-1}$; detektálás 221-280 nm; hőmérséklet, HPLC $25^{\circ} \mathrm{C}$, SFC $40{ }^{\circ} \mathrm{C}$. 


\begin{tabular}{|c|c|c|c|c|c|c|c|c|}
\hline \multirow[t]{2}{*}{ Vegyület } & $k_{1}$ & $\alpha$ & $R s$ & \multirow{2}{*}{$\begin{array}{l}\text { Elúciós } \\
\text { sorrend }\end{array}$} & $k_{1}$ & $\alpha$ & $R s$ & \multirow{2}{*}{$\begin{array}{l}\text { Elúciós } \\
\text { sorrend }\end{array}$} \\
\hline & \multicolumn{3}{|c|}{ ZWIX(+) } & & & \multicolumn{2}{|c|}{$Z W I X(-)$} & \\
\hline 1 & 1,92 & 1,19 & 1,60 & $\mathrm{DD}<\mathrm{LL}$ & 1,30 & 1,62 & 3,47 & $\mathrm{LL}<\mathrm{DD}$ \\
\hline 1 & 1,82 & 1,09 & 0,80 & $\mathrm{DL}<\mathrm{LD}$ & 1,35 & 1,00 & 0,00 & - \\
\hline 2 & 2,24 & 1,18 & 1,53 & $\mathrm{DD}<\mathrm{LL}$ & 3,28 & 1,34 & 2,19 & $\mathrm{LL}<\mathrm{DD}$ \\
\hline 3 & 2,10 & 1,00 & 0,00 & - & 1,37 & 1,00 & 0,00 & - \\
\hline 4 & 1,78 & 1,20 & 1,79 & $\mathrm{DD}<\mathrm{LL}$ & 1,24 & 1,44 & 1,91 & $\mathrm{LL}<\mathrm{DD}$ \\
\hline 4 & 1,69 & 1,12 & 0,97 & $\mathrm{DL}<\mathrm{LD}$ & 1,26 & 1,00 & 0,00 & - \\
\hline 5 & 2,01 & 1,15 & 1,17 & $\mathrm{DD}<\mathrm{LL}$ & 1,38 & 1,43 & 2,38 & $\mathrm{LL}<\mathrm{DD}$ \\
\hline 6 & 4,96 & 1,68 & 4,47 & $\mathrm{D}<\mathrm{L}$ & 5,64 & 1,41 & 2,92 & $\mathrm{~L}<\mathrm{D}$ \\
\hline 7 & 0,10 & 1,00 & 0,00 & - & 0,10 & 1,00 & 0,00 & - \\
\hline 8 & 1,19 & 1,08 & 0,48 & $\mathrm{DD}<\mathrm{LL}$ & 0,88 & 1,46 & 1,43 & $\mathrm{LL}<\mathrm{DD}$ \\
\hline 9 & 1,90 & 1,34 & 2,79 & $\mathrm{DD}<\mathrm{LL}$ & 1,24 & 1,67 & 2,82 & $\mathrm{LL}<\mathrm{DD}$ \\
\hline 10 & 2,55 & 1,44 & 3,75 & $\mathrm{DD}<\mathrm{LL}$ & 2,00 & 1,97 & 4,84 & $\mathrm{LL}<\mathrm{DD}$ \\
\hline 11 & 2,62 & 2,85 & 8,00 & $\mathrm{DD}<\mathrm{LL}$ & 1,53 & 2,52 & 7,00 & $\mathrm{LL}<\mathrm{DD}$ \\
\hline 12 & 3,03 & 1,00 & 0,00 & - & 1,98 & 1,20 & 0,65 & $\mathrm{~L}<\mathrm{D}$ \\
\hline 13 & 2,59 & 1,44 & 3,79 & $\mathrm{D}<\mathrm{L}$ & 2,34 & 1,29 & 2,24 & $\mathrm{~L}<\mathrm{D}$ \\
\hline 14 & 1,65 & 2,72 & 4,47 & $\mathrm{DD}<\mathrm{LL}$ & 1,22 & 2,05 & 3,69 & $\mathrm{LL}<\mathrm{DD}$ \\
\hline 14 & 1,90 & 1,51 & 2,84 & $\mathrm{DL}<\mathrm{LD}$ & 1,35 & 1,08 & 0,40 & $\mathrm{LD}<\mathrm{DL}$ \\
\hline 15 & 1,70 & 1,69 & 4,18 & $\mathrm{DD}<\mathrm{LL}$ & 2,23 & 1,39 & 3,20 & $\mathrm{LL}<\mathrm{DD}$ \\
\hline 16 & 1,25 & 1,46 & 2,96 & $\mathrm{DD}<\mathrm{LL}$ & 1,15 & 1,41 & 1,91 & $\mathrm{LL}<\mathrm{DD}$ \\
\hline 16 & 1,01 & 1,04 & 0,32 & $\mathrm{DL}<\mathrm{LD}$ & 0,66 & 1,24 & 1,05 & $\mathrm{DL}<\mathrm{LD}$ \\
\hline \multicolumn{5}{|c|}{$Q N-A X$} & \multicolumn{4}{|c|}{$Q D-A X$} \\
\hline 1 & 0,46 & 1,25 & 0,63 & $\mathrm{DD}<\mathrm{LL}$ & 0,34 & 1,51 & 0,63 & $\mathrm{LL}<\mathrm{DD}$ \\
\hline 1 & 0,45 & 1,00 & 0,00 & - & 0,39 & 1,00 & 0,00 & - \\
\hline 2 & 0,78 & 1,57 & 1,93 & $\mathrm{DD}<\mathrm{LL}$ & 0,59 & 1,75 & 2,63 & $\mathrm{LL}<\mathrm{DD}$ \\
\hline 3 & 0,13 & 1,00 & 0,00 & - & 0,17 & 1,00 & 0,00 & - \\
\hline 4 & 0,57 & 1,50 & 1,31 & $\mathrm{DD}<\mathrm{LL}$ & 0,43 & 1,74 & 1,82 & $\mathrm{LL}<\mathrm{DD}$ \\
\hline 4 & 0,43 & 1,20 & 0,33 & $\mathrm{LD}<\mathrm{DL}$ & 0,38 & 1,26 & 0,58 & $\mathrm{DL}<\mathrm{LD}$ \\
\hline 5 & 0,54 & 1,31 & 0,75 & $\mathrm{DD}<\mathrm{LL}$ & 0,39 & 1,56 & 1,19 & $\mathrm{LL}<\mathrm{DD}$ \\
\hline 6 & 0,62 & 1,16 & 0,39 & $\mathrm{D}<\mathrm{L}$ & 0,52 & 1,30 & 0,80 & $\mathrm{~L}<\mathrm{D}$ \\
\hline 7 & $*$ & - & - & - & $*$ & - & - & - \\
\hline 8 & $*$ & - & - & - & $*$ & - & - & - \\
\hline 9 & 0,53 & 1,62 & 1,56 & $\mathrm{DD}<\mathrm{LL}$ & 0,39 & 1,78 & 1,74 & $\mathrm{LL}<\mathrm{DD}$ \\
\hline 10 & 0,93 & 1,27 & 1,33 & $\mathrm{DD}<\mathrm{LL}$ & 0,79 & 1,39 & 1,67 & $\mathrm{LL}<\mathrm{DD}$ \\
\hline 11 & 0,60 & 2,08 & 3,33 & $\mathrm{DD}<\mathrm{LL}$ & 0,46 & 2,16 & 3,58 & $\mathrm{LL}<\mathrm{DD}$ \\
\hline 12 & 0,66 & 1,29 & 0,60 & $\mathrm{D}<\mathrm{L}$ & 0,51 & 1,42 & 0,92 & $\mathrm{~L}<\mathrm{D}$ \\
\hline 13 & 0,43 & 1,36 & 1,18 & $\mathrm{D}<\mathrm{L}$ & 0,41 & 1,37 & 0,94 & $\mathrm{~L}<\mathrm{D}$ \\
\hline 14 & 0,55 & 1,84 & 1,43 & $\mathrm{DD}<\mathrm{LL}$ & 0,38 & 2,67 & 3,50 & $\mathrm{LL}<\mathrm{DD}$ \\
\hline 14 & 1,98 & 1,00 & 0,00 & - & 1,58 & 1,00 & 0,00 & - \\
\hline 15 & 0,30 & 1,00 & 0,00 & - & 0,22 & 2,35 & 1,12 & $\mathrm{LL}<\mathrm{DD}$ \\
\hline 16 & 0,24 & 2,61 & 1,73 & $\mathrm{DD}<\mathrm{LL}$ & 0,15 & 3,74 & 2,60 & $\mathrm{LL}<\mathrm{DD}$ \\
\hline 16 & 0,28 & 1,00 & 0,00 & - & 0,20 & 1,00 & 0,00 & - \\
\hline
\end{tabular}

F3 táblázat Biológiailag aktív dipeptidek kromatográfiás paraméterei és az enantiomerek elúciós sorrendje cinkóna alkaloid alapú állófázisokon MeOH/THF eluens esetén

Kromatográfiás körülmények: kolonna, ZWIX(+), ZWIX(-), QN-AX, QD-AX; mozgófázis, MeOH/THF (70/30 $v / v)$ és DEA $(25 \mathrm{mM})$ és FA $(50 \mathrm{mM})$; áramlási sebesség, $0,6 \mathrm{ml} \mathrm{perc}^{-1}$; detektálás, 221-280 nm; hőmérséklet, $25^{\circ} \mathrm{C}, *$ holtidő előtti elúció. 


\begin{tabular}{|c|c|c|c|c|c|c|c|c|}
\hline \multirow[t]{2}{*}{ Vegyület } & $N_{1} m^{-1}$ & $N_{2} m^{-1}$ & $N_{1} m^{-1}$ & $\mathrm{~N}_{2} \mathrm{~m}^{-1}$ & $N_{I} m^{-I}$ & $N_{2} m^{-1}$ & $N_{1} m^{-1}$ & $N_{2} m^{-I}$ \\
\hline & \multicolumn{2}{|c|}{$\mathrm{MeOH} / \mathrm{MeCN}$} & \multicolumn{2}{|c|}{ MeOH/THF } & \multicolumn{2}{|c|}{ MeOH/MeCN } & \multicolumn{2}{|c|}{ MeOH/THF } \\
\hline \multicolumn{5}{|c|}{$Z W I X(+)$} & \multicolumn{4}{|c|}{$Z W I X(-)$} \\
\hline 1 & 12067 & 6113 & 35027 & 26427 & 7513 & 4793 & 13547 & 7493 \\
\hline 1 & 10847 & 5673 & 25427 & 20920 & 5547 & 3407 & 8347 & - \\
\hline 2 & 19140 & 14880 & 27880 & 18713 & 24267 & 14680 & 12933 & 12540 \\
\hline 3 & 27427 & 20493 & 17333 & - & 21787 & - & 7920 & - \\
\hline 4 & 20553 & 17280 & 29860 & 29213 & 17413 & 12220 & 12027 & 11533 \\
\hline 4 & 13813 & 10760 & 29987 & 23647 & 25447 & 19087 & 13367 & - \\
\hline 5 & 11667 & - & 34847 & 19880 & 11027 & 10320 & 13093 & 12740 \\
\hline 6 & 23207 & 17407 & 29460 & 26780 & 30560 & 13133 & 16927 & 8467 \\
\hline 7 & 6113 & - & 8093 & - & 3880 & - & 7040 & - \\
\hline 8 & 11313 & - & 8793 & 7487 & 5433 & 4467 & 8953 & 8493 \\
\hline 9 & 15447 & 12640 & 28400 & 20120 & 12680 & 10320 & 15433 & 15100 \\
\hline 10 & 8320 & 5607 & 30833 & 29120 & 7380 & 6940 & 16860 & 16340 \\
\hline 11 & 17993 & 16727 & 20007 & 15353 & 23807 & 21987 & 13907 & 12947 \\
\hline 12 & 6440 & - & 9993 & - & 6673 & 5447 & 5733 & 5347 \\
\hline 13 & 28593 & 23840 & 23367 & 20720 & 16560 & 16367 & 23547 & 15793 \\
\hline 14 & 12347 & 11487 & 25380 & 20187 & 11693 & 10487 & 16193 & 11660 \\
\hline 14 & 10000 & 8987 & 12173 & 10820 & 12447 & 7500 & 7513 & 5393 \\
\hline 15 & 14760 & 12473 & 21407 & 17520 & 17533 & 13140 & 27067 & 21333 \\
\hline 16 & 22707 & 13873 & 18933 & 18167 & 9900 & 7920 & 13447 & 10307 \\
\hline 16 & 12140 & 7820 & 17193 & 10740 & 13280 & 6833 & 21040 & 12853 \\
\hline \multicolumn{5}{|c|}{$Q N-A X$} & \multicolumn{4}{|c|}{$Q D-A X$} \\
\hline 1 & 11220 & - & 26573 & 8960 & 23560 & 16907 & 23113 & 9460 \\
\hline 1 & 6387 & - & 4773 & - & 5413 & - & 6720 & - \\
\hline 2 & 20713 & 14380 & 12140 & 10253 & 17727 & 14593 & 19927 & 13793 \\
\hline 3 & 2893 & - & 6253 & - & 1940 & - & 4893 & - \\
\hline 4 & 22747 & 11200 & 10340 & 6387 & 28087 & 19500 & 10693 & 8980 \\
\hline 4 & 3313 & - & 9420 & 4140 & 5240 & - & 8427 & 7707 \\
\hline 5 & 37833 & - & 8993 & 7980 & 23567 & 21473 & 8053 & 6053 \\
\hline 6 & 13007 & - & 5420 & 4160 & 17320 & 11700 & 7913 & 7673 \\
\hline 7 & - & - & - & - & - & - & - & - \\
\hline 8 & - & - & - & - & - & - & - & - \\
\hline 9 & 22440 & 21213 & 8113 & 7553 & 27293 & 25473 & 9947 & 8673 \\
\hline 10 & 30800 & 30393 & 17153 & 14687 & 27200 & 23867 & 16433 & 14027 \\
\hline 11 & 24907 & 9940 & 19880 & 9107 & 16540 & 15620 & 13053 & 9900 \\
\hline 12 & 26847 & - & 6073 & 4227 & 24127 & 19393 & 11987 & 8240 \\
\hline 13 & 9393 & 8193 & 15340 & 13360 & 10140 & 7480 & 8040 & 7533 \\
\hline 14 & 23800 & 12600 & 8160 & 5053 & 20467 & 9727 & 9807 & 8567 \\
\hline 14 & 34133 & - & 35200 & - & 33000 & - & 34820 & - \\
\hline 15 & 23507 & - & 15407 & - & 30480 & 24520 & 16940 & 10427 \\
\hline 16 & 12187 & 10147 & 7547 & 4113 & 17907 & 15400 & 13527 & 13387 \\
\hline 16 & 2753 & - & 5047 & - & 2793 & - & 5940 & - \\
\hline
\end{tabular}

F4 táblázat $\mathrm{Az}$ elméleti tányérszám adatok áttekintése $\mathrm{MeOH} / \mathrm{MeCN}$ és $\mathrm{MeOH} / \mathrm{THF}$ összetételü mozgófázisok és cinkóna alkaloid alapú állófázisok alkalmazása esetén Kromatográfiás körülmények: kolonna, $Z W I X(+), Z W I X(-), Q N-A X$ és $Q D-A X$; mozgófázis, MeOH/MeCN $(50 / 50 v / v)$ és DEA $(25 \mathrm{mM})$ és FA (50 mM), illetve MeOH/THF (70/30 v/v) és DEA (25 mM) és FA (50 mM); áramlási sebesség, $0,6 \mathrm{ml}$ perc ${ }^{-1}$; detektálás, $221-280 \mathrm{~nm}$, hömérséklet, $25^{\circ} \mathrm{C}$. 

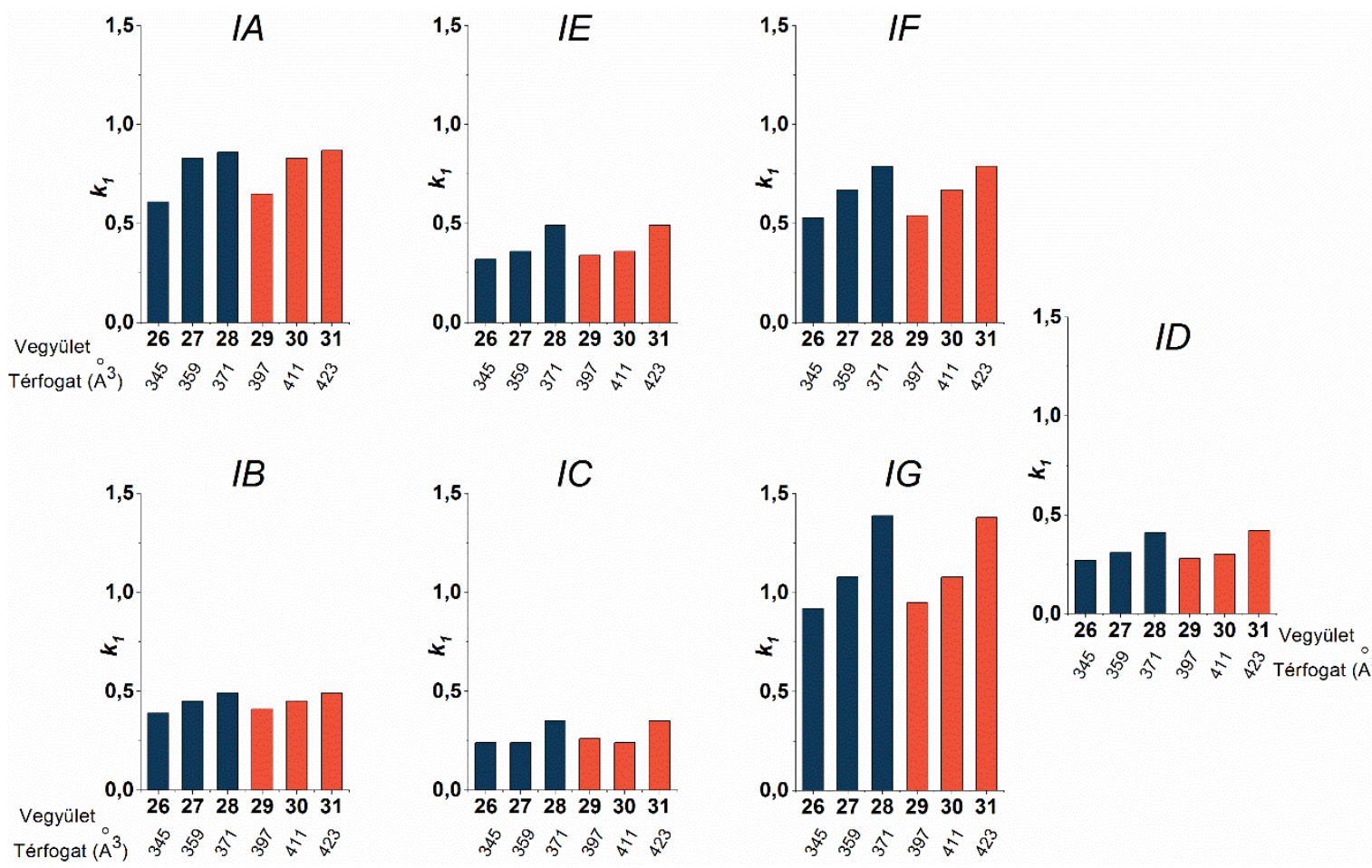
ले के ले के से ॠँ Térfogat $\left(\hat{A}^{3}\right)$

F9 ábra A molekulatérfogat és az elsőként eluálódó enantiomer retenciós tényezőjének kapcsolata SFC technika esetén

Kromatográfiás körülmények: kolonna, $I A, I B, I C, I D, I E, I F, I G$; mozgófázis, $\mathrm{MeOH} / \mathrm{CO}_{2}(50 / 50 v / v)$ és DEA $\left(20 \mathrm{mM}\right.$ ); áramlási sebesség, $2,0 \mathrm{ml}$ perc ${ }^{-1}$; detektálás, $215-250 \mathrm{~nm}$; hömérséklet, $40^{\circ} \mathrm{C}$, ellennyomás 150 bar. 


\begin{tabular}{|c|c|c|c|c|c|c|c|}
\hline \multirow{2}{*}{ Vegyület } & \multirow{2}{*}{$k_{1}, \alpha, R_{S}$} & \multicolumn{6}{|c|}{ Hőmérséklet $\left({ }^{\circ} \mathbf{C}\right)$} \\
\hline & & $5^{\circ} \mathrm{C}$ & $10^{\circ} \mathrm{C}$ & $20^{\circ} \mathrm{C}$ & $30^{\circ} \mathrm{C}$ & $40^{\circ} \mathrm{C}$ & $50^{\circ} \mathrm{C}$ \\
\hline \multicolumn{8}{|c|}{$Z W I X(+)$} \\
\hline \multirow{3}{*}{2} & $k_{1}$ & 2,39 & 2,36 & 2,27 & 2,25 & 2,16 & 2,10 \\
\hline & $\alpha$ & 1,13 & 1,13 & 1,12 & 1,11 & 1,10 & 1,09 \\
\hline & $\boldsymbol{R}_{S}$ & 1,05 & 1,04 & 1,09 & 0,92 & 0,69 & 0,42 \\
\hline \multirow{3}{*}{6} & $k_{1}$ & 5,00 & 4,87 & 4,67 & 4,52 & 4,36 & 4,23 \\
\hline & $\alpha$ & 1,54 & 1,51 & 1,46 & 1,41 & 1,36 & 1,32 \\
\hline & $\boldsymbol{R}_{S}$ & 5,41 & 5,18 & 4,94 & 4,00 & 3,89 & 3,46 \\
\hline \multirow{3}{*}{9} & $k_{1}$ & 2,67 & 2,66 & 2,65 & 2,65 & 2,54 & 2,48 \\
\hline & $\alpha$ & 1,25 & 1,25 & 1,23 & 1,21 & 1,20 & 1,17 \\
\hline & $\boldsymbol{R}_{S}$ & 1,85 & 2,00 & 1,81 & 1,81 & 1,46 & 0,88 \\
\hline \multirow{3}{*}{11} & $k_{1}$ & 3,51 & 3,51 & 3,39 & 3,36 & 3,26 & 3,04 \\
\hline & $\alpha$ & 2,57 & 2,48 & 2,29 & 2,13 & 1,98 & 1,86 \\
\hline & $\boldsymbol{R}_{S}$ & 9,29 & 9,17 & 8,59 & 7,37 & 5,64 & 3,20 \\
\hline \multirow{3}{*}{16} & $k_{1}$ & 1,91 & 1,89 & 1,77 & 1,66 & 1,47 & 1,35 \\
\hline & $\alpha$ & 1,19 & 1,19 & 1,18 & 1,18 & 1,16 & 1,15 \\
\hline & $\boldsymbol{R}_{S}$ & 1,07 & 1,36 & 1,33 & 1,36 & 1,40 & 1,00 \\
\hline \multicolumn{8}{|c|}{$Z W I X(-)$} \\
\hline \multirow{3}{*}{2} & $k_{1}$ & 1,28 & 1,27 & 1,38 & 1,46 & 1,49 & 1,49 \\
\hline & $\alpha$ & 1,29 & 1,28 & 1,25 & 1,22 & 1,20 & 1,17 \\
\hline & $\boldsymbol{R}_{S}$ & 1,33 & 1,43 & 1,31 & 1,17 & 1,00 & 0,85 \\
\hline \multirow{3}{*}{6} & $k_{1}$ & 3,84 & 3,94 & 4,17 & 4,39 & 4,53 & 4,64 \\
\hline & $\alpha$ & 1,53 & 1,51 & 1,47 & 1,43 & 1,39 & 1,36 \\
\hline & $\boldsymbol{R}_{S}$ & 3,12 & 3,20 & 3,45 & 3,80 & 3,36 & 3,56 \\
\hline \multirow{3}{*}{9} & $k_{1}$ & 1,28 & 1,40 & 1,50 & 1,59 & 1,71 & 1,68 \\
\hline & $\alpha$ & 1,54 & 1,52 & 1,47 & 1,43 & 1,36 & 1,33 \\
\hline & $\boldsymbol{R}_{S}$ & 2,00 & 2,07 & 2,22 & 2,07 & 2,00 & 1,15 \\
\hline \multirow{3}{*}{11} & $k_{1}$ & 1,61 & 1,73 & 1,86 & 1,98 & 2,05 & 2,06 \\
\hline & $\alpha$ & 2,17 & 2,12 & 2,00 & 1,89 & 1,78 & 1,68 \\
\hline & $\boldsymbol{R}_{S}$ & 4,87 & 4,96 & 4,87 & 4,78 & 3,46 & 2,14 \\
\hline \multirow{3}{*}{16} & $k_{1}$ & 1,19 & 1,23 & 1,26 & 1,28 & 1,24 & 1,13 \\
\hline & $\alpha$ & 1,21 & 1,20 & 1,19 & 1,18 & 1,16 & 1,15 \\
\hline & $\boldsymbol{R}_{S}$ & 0,55 & 0,76 & 0,79 & 0,73 & 0,77 & 0,70 \\
\hline
\end{tabular}

F5 táblázat A kromatográfiás paraméterek változása a hőmérséklet-változtatás függvényében cinkóna alkaloid alapú állófázisok esetén

Kromatográfiás körülmények: kolonna, $Z W I X(+)$, és $Z W I X(-)$; mozgófázis, MeOH/MeCN (50/50 v/v) és DEA (25 mM) és FA (50 mM); áramlási sebesség, 0,6 $\mathrm{ml} \mathrm{perc}^{-1}$; detektálás, 221-280 nm; hömérséklet-tartomány, 5$50{ }^{\circ} \mathrm{C}$. 


\begin{tabular}{|c|c|c|c|c|c|c|c|}
\hline \multirow{2}{*}{ Vegyület } & \multirow{2}{*}{$k_{1}, \alpha, R_{S}$} & \multicolumn{6}{|c|}{ Hőmérséklet $\left({ }^{\circ} \mathbf{C}\right)$} \\
\hline & & $5^{\circ} \mathrm{C}$ & $10^{\circ} \mathrm{C}$ & $20^{\circ} \mathrm{C}$ & $30^{\circ} \mathrm{C}$ & $40^{\circ} \mathrm{C}$ & $50^{\circ} \mathrm{C}$ \\
\hline \multicolumn{8}{|c|}{$Q N-A X$} \\
\hline \multirow{3}{*}{2} & $k_{1}$ & 0,96 & 0,99 & 0,99 & 1,02 & 0,97 & 0,85 \\
\hline & $\alpha$ & 1,58 & 1,54 & 1,47 & 1,38 & 1,35 & 1,34 \\
\hline & $\boldsymbol{R}_{S}$ & 2,86 & 2,86 & 2,60 & 1,65 & 1,36 & 1,07 \\
\hline \multirow{3}{*}{6} & $k_{1}$ & 0,84 & 0,85 & 0,88 & 0,91 & 0,96 & 1,01 \\
\hline & $\alpha$ & 1,16 & 1,14 & 1,10 & 1,00 & 1,00 & 1,00 \\
\hline & $\boldsymbol{R}_{S}$ & 0,67 & 0,64 & 0,42 & 0,00 & 0,00 & 0,00 \\
\hline \multirow{3}{*}{9} & $k_{1}$ & 0,95 & 0,98 & 1,03 & 1,12 & 1,23 & 1,33 \\
\hline & $\alpha$ & 1,50 & 1,47 & 1,38 & 1,24 & 1,09 & 0,98 \\
\hline & $\boldsymbol{R}_{S}$ & 2,26 & 2,15 & 2,10 & 1,70 & 0,70 & 0,50 \\
\hline \multirow{3}{*}{11} & $k_{1}$ & 1,07 & 1,09 & 1,13 & 1,19 & 1,28 & 1,36 \\
\hline & $\alpha$ & 1,76 & 1,69 & 1,56 & 1,42 & 1,25 & 1,15 \\
\hline & $\boldsymbol{R}_{S}$ & 3,88 & 3,61 & 3,47 & 2,33 & 1,36 & 1,24 \\
\hline \multirow{3}{*}{16} & $k_{1}$ & 0,38 & 0,44 & 0,51 & 0,55 & 0,64 & 0,72 \\
\hline & $\alpha$ & 3,31 & 2,81 & 2,24 & 2,07 & 1,50 & 1,35 \\
\hline & $\boldsymbol{R}_{S}$ & 4,57 & 3,11 & 2,48 & 2,45 & 1,33 & 1,17 \\
\hline \multicolumn{8}{|c|}{$Q D-A X$} \\
\hline \multirow{3}{*}{2} & $k_{1}$ & 0,87 & 0,89 & 0,91 & 0,92 & 0,91 & 0,84 \\
\hline & $\alpha$ & 1,74 & 1,69 & 1,58 & 1,48 & 1,38 & 1,30 \\
\hline & $\boldsymbol{R}_{S}$ & 3,16 & 2,95 & 2,75 & 1,90 & 1,74 & 1,52 \\
\hline \multirow{3}{*}{6} & $k_{1}$ & 0,83 & 0,83 & 0,84 & 0,83 & 0,81 & 0,79 \\
\hline & $\alpha$ & 1,26 & 1,25 & 1,21 & 1,18 & 1,15 & 1,11 \\
\hline & $\boldsymbol{R}_{S}$ & 1,21 & 1,12 & 0,88 & 0,47 & 0,52 & 0,23 \\
\hline \multirow{3}{*}{9} & $k_{1}$ & 0,85 & 0,88 & 0,92 & 0,93 & 0,98 & 0,95 \\
\hline & $\alpha$ & 1,67 & 1,61 & 1,50 & 1,45 & 1,34 & 1,29 \\
\hline & $\boldsymbol{R}_{S}$ & 3,11 & 2,81 & 2,27 & 1,18 & 0,96 & 0,94 \\
\hline \multirow{3}{*}{11} & $k_{1}$ & 1,00 & 1,04 & 1,09 & 1,10 & 1,09 & 1,11 \\
\hline & $\alpha$ & 1,96 & 1,84 & 1,66 & 1,51 & 1,42 & 1,32 \\
\hline & $\boldsymbol{R}_{S}$ & 4,20 & 3,89 & 3,63 & 2,50 & 2,25 & 2,08 \\
\hline \multirow{3}{*}{16} & $k_{1}$ & 0,42 & 0,44 & 0,45 & 0,48 & 0,49 & 0,49 \\
\hline & $\alpha$ & 3,34 & 3,09 & 2,84 & 2,50 & 2,24 & 2,11 \\
\hline & $\boldsymbol{R}_{S}$ & 4,00 & 3,90 & 3,20 & 3,06 & 2,36 & 2,56 \\
\hline
\end{tabular}

F6 táblázat A kromatográfiás paraméterek változása a hőmérséklet-változtatás függvényében cinkóna alkaloid alapú állófázisok esetén

Kromatográfiás körülmények: kolonna, $Q N-A X$, és $Q D-A X$; mozgófázis, $\mathrm{MeOH} / \mathrm{MeCN}(50 / 50 v / v)$ és DEA (25 mM) és FA (50 mM); áramlási sebesség, 0,6 $\mathrm{ml} \mathrm{perc}^{-1}$; detektálás, 221-280 nm; hőmérséklet-tartomány, 5$50{ }^{\circ} \mathrm{C}$. 


\begin{tabular}{|c|c|c|c|c|c|c|c|}
\hline \multirow{2}{*}{ Vegyület } & \multirow{2}{*}{$k_{1}, \alpha, R_{S}$} & \multicolumn{6}{|c|}{ Hőmérséklet $\left({ }^{\circ} \mathbf{C}\right)$} \\
\hline & & $5^{\circ} \mathrm{C}$ & $10^{\circ} \mathrm{C}$ & $20^{\circ} \mathrm{C}$ & $30^{\circ} \mathrm{C}$ & $40^{\circ} \mathrm{C}$ & $50^{\circ} \mathrm{C}$ \\
\hline \multicolumn{8}{|c|}{$Z W I X(+)$} \\
\hline \multirow{3}{*}{2} & $k_{1}$ & 2,42 & 2,36 & 2,26 & 2,17 & 2,05 & 1,91 \\
\hline & $\alpha$ & 1,23 & 1,22 & 1,20 & 1,18 & 1,16 & 1,14 \\
\hline & $\boldsymbol{R}_{S}$ & 1,75 & 1,65 & 1,64 & 1,62 & 1,18 & 0,93 \\
\hline \multirow{3}{*}{6} & $k_{1}$ & 5,85 & 5,58 & 5,09 & 4,62 & 4,28 & 3,96 \\
\hline & $\alpha$ & 1,59 & 1,55 & 1,49 & 1,41 & 1,36 & 1,31 \\
\hline & $\boldsymbol{R}_{S}$ & 5,00 & 4,67 & 4,62 & 4,11 & 3,58 & 2,95 \\
\hline \multirow{3}{*}{9} & $k_{1}$ & 1,87 & 1,83 & 1,83 & 1,84 & 1,81 & 1,70 \\
\hline & $\alpha$ & 1,41 & 1,40 & 1,37 & 1,33 & 1,30 & 1,26 \\
\hline & $\boldsymbol{R}_{S}$ & 2,76 & 2,73 & 2,76 & 2,53 & 1,92 & 1,46 \\
\hline \multirow{3}{*}{11} & $k_{1}$ & 2,45 & 2,44 & 2,48 & 2,46 & 2,41 & 2,31 \\
\hline & $\alpha$ & 3,19 & 3,15 & 2,89 & 2,66 & 2,44 & 2,23 \\
\hline & $\boldsymbol{R}_{S}$ & 9,88 & 9,56 & 9,56 & 9,29 & 8,33 & 4,86 \\
\hline \multirow{3}{*}{16} & $k_{1}$ & 1,39 & 1,35 & 1,25 & 1,18 & 1,07 & 0,96 \\
\hline & $\alpha$ & 1,45 & 1,44 & 1,42 & 1,39 & 1,35 & 1,31 \\
\hline & $\boldsymbol{R}_{S}$ & 2,55 & 2,57 & 2,43 & 2,35 & 2,09 & 2,11 \\
\hline \multicolumn{8}{|c|}{$Z W I X(-)$} \\
\hline \multirow{3}{*}{2} & $k_{1}$ & 1,37 & 1,38 & 1,42 & 1,44 & 1,46 & 1,44 \\
\hline & $\alpha$ & 1,49 & 1,46 & 1,41 & 1,35 & 1,31 & 1,27 \\
\hline & $\boldsymbol{R}_{S}$ & 2,29 & 2,14 & 2,07 & 1,93 & 1,59 & 1,29 \\
\hline \multirow{3}{*}{6} & $k_{1}$ & 5,76 & 5,52 & 5,35 & 5,17 & 4,95 & 4,76 \\
\hline & $\alpha$ & 1,62 & 1,58 & 1,52 & 1,45 & 1,40 & 1,35 \\
\hline & $\boldsymbol{R}_{S}$ & 4,95 & 3,92 & 4,60 & 4,20 & 3,29 & 3,14 \\
\hline \multirow{3}{*}{9} & $k_{1}$ & 1,01 & 1,05 & 1,11 & 1,17 & 1,23 & 1,25 \\
\hline & $\alpha$ & 1,84 & 1,81 & 1,73 & 1,64 & 1,56 & 1,48 \\
\hline & $\boldsymbol{R}_{S}$ & 3,08 & 3,04 & 2,85 & 2,85 & 2,69 & 2,14 \\
\hline \multirow{3}{*}{11} & $k_{1}$ & 1,30 & 1,30 & 1,39 & 1,47 & 1,54 & 1,58 \\
\hline & $\alpha$ & 2,85 & 2,73 & 2,54 & 2,35 & 2,18 & 2,00 \\
\hline & $\boldsymbol{R}_{S}$ & 6,00 & 6,57 & 6,48 & 6,60 & 5,39 & 3,76 \\
\hline \multirow{3}{*}{16} & $k_{1}$ & 0,99 & 0,98 & 0,97 & 0,98 & 0,95 & 0,90 \\
\hline & $\alpha$ & 1,56 & 1,54 & 1,50 & 1,45 & 1,40 & 1,35 \\
\hline & $\boldsymbol{R}_{S}$ & 1,94 & 1,76 & 1,86 & 1,79 & 2,12 & 1,54 \\
\hline
\end{tabular}

F7 táblázat A kromatográfiás paraméterek változása a hőmérséklet-változtatás függvényében cinkóna alkaloid alapú állófázisok esetén

Kromatográfiás körülmények: kolonna, $Z W I X(+)$ és $Z W I X(-)$; mozgófázis, MeOH/THF (70/30 v/v) és DEA (25 mM) és FA (50 mM); áramlási sebesség, 0,6 $\mathrm{ml} \mathrm{perc}^{-1}$; detektálás, 221-280 nm; hőmérséklet-tartomány, 5$50{ }^{\circ} \mathrm{C}$. 


\begin{tabular}{|c|c|c|c|c|c|c|c|}
\hline \multirow{2}{*}{ Vegyület } & \multirow{2}{*}{$k_{1}, \alpha, R_{S}$} & \multicolumn{6}{|c|}{ Hőmérséklet $\left({ }^{\circ} \mathbf{C}\right)$} \\
\hline & & $5^{\circ} \mathrm{C}$ & $10^{\circ} \mathrm{C}$ & $20^{\circ} \mathrm{C}$ & $30^{\circ} \mathrm{C}$ & $40^{\circ} \mathrm{C}$ & $50^{\circ} \mathrm{C}$ \\
\hline \multicolumn{8}{|c|}{$Q N-A X$} \\
\hline \multirow{3}{*}{2} & $k_{1}$ & 0,76 & 0,74 & 0,72 & 0,70 & 0,63 & 0,61 \\
\hline & $\alpha$ & 1,70 & 1,67 & 1,61 & 1,56 & 1,50 & 1,41 \\
\hline & $\boldsymbol{R}_{S}$ & 2,24 & 2,18 & 1,85 & 1,31 & 0,73 & 0,56 \\
\hline \multirow{3}{*}{6} & $k_{1}$ & 0,61 & 0,60 & 0,57 & 0,53 & 0,50 & 0,47 \\
\hline & $\alpha$ & 1,25 & 1,21 & 1,17 & 1,13 & 1,00 & 1,00 \\
\hline & $\boldsymbol{R}_{S}$ & 0,62 & 0,51 & 0,40 & 0,27 & 0,00 & 0,00 \\
\hline \multirow{3}{*}{9} & $k_{1}$ & 0,49 & 0,49 & 0,50 & 0,51 & 0,51 & 0,51 \\
\hline & $\alpha$ & 1,88 & 1,87 & 1,69 & 1,53 & 1,41 & 1,31 \\
\hline & $\boldsymbol{R}_{S}$ & 2,11 & 2,06 & 1,36 & 1,03 & 0,67 & 0,38 \\
\hline \multirow{3}{*}{11} & $k_{1}$ & 0,56 & 0,57 & 0,58 & 0,60 & 0,61 & 0,62 \\
\hline & $\alpha$ & 2,47 & 2,33 & 2,09 & 1,89 & 1,63 & 1,45 \\
\hline & $\boldsymbol{R}_{S}$ & 3,88 & 3,90 & 2,91 & 2,17 & 0,94 & 0,81 \\
\hline \multirow{3}{*}{16} & $k_{1}$ & 0,20 & 0,21 & 0,21 & 0,22 & 0,22 & 0,22 \\
\hline & $\alpha$ & 3,46 & 3,14 & 2,89 & 2,57 & 2,24 & 1,91 \\
\hline & $\boldsymbol{R}_{S}$ & 2,24 & 2,17 & 1,90 & 1,84 & 1,42 & 1,00 \\
\hline \multicolumn{8}{|c|}{$Q D-A X$} \\
\hline \multirow{3}{*}{2} & $k_{1}$ & 0,62 & 0,61 & 0,59 & 0,57 & 0,57 & 0,54 \\
\hline & $\alpha$ & 1,87 & 1,83 & 1,75 & 1,65 & 1,58 & 1,50 \\
\hline & $\boldsymbol{R}_{S}$ & 2,67 & 2,38 & 2,32 & 1,58 & 0,87 & 0,63 \\
\hline \multirow{3}{*}{6} & $k_{1}$ & 0,58 & 0,57 & 0,56 & 0,50 & 0,47 & 0,45 \\
\hline & $\alpha$ & 1,37 & 1,33 & 1,28 & 1,24 & 1,19 & 1,17 \\
\hline & $\boldsymbol{R}_{S}$ & 1,20 & 1,00 & 0,78 & 0,57 & 0,43 & 0,41 \\
\hline \multirow{3}{*}{9} & $k_{1}$ & 0,40 & 0,41 & 0,42 & 0,44 & 0,48 & 0,50 \\
\hline & $\alpha$ & 2,13 & 2,05 & 1,80 & 1,58 & 1,38 & 1,28 \\
\hline & $\boldsymbol{R}_{S}$ & 2,61 & 2,15 & 1,64 & 1,15 & 0,54 & 0,35 \\
\hline \multirow{3}{*}{11} & $k_{1}$ & 0,50 & 0,51 & 0,52 & 0,53 & 0,55 & 0,58 \\
\hline & $\alpha$ & 2,55 & 2,41 & 2,10 & 1,79 & 1,54 & 1,37 \\
\hline & $\boldsymbol{R}_{S}$ & 3,75 & 3,66 & 3,04 & 1,24 & 0,94 & 0,90 \\
\hline \multirow{3}{*}{16} & $k_{1}$ & 0,16 & 0,16 & 0,18 & 0,19 & 0,20 & 0,22 \\
\hline & $\alpha$ & 5,15 & 4,23 & 3,53 & 2,95 & 2,46 & 1,95 \\
\hline & $\boldsymbol{R}_{S}$ & 4,17 & 2,31 & 2,30 & 2,00 & 1,41 & 1,20 \\
\hline
\end{tabular}

F8 táblázat A kromatográfiás paraméterek változása a hőmérséklet-változtatás függvényében cinkóna alkaloid alapú állófázisok esetén

Kromatográfiás körülmények: kolonna, $Q N-A X$, és $Q D-A X$; mozgófázis, MeOH/THF (70/30 v/v) és DEA (25 $\mathrm{mM}$ ) és FA (50 mM); áramlási sebesség, $0,6 \mathrm{ml} \mathrm{perc}^{-1}$; detektálás, 221-280 nm; hömérséklet-tartomány, 5-50 ${ }^{\circ} \mathrm{C}$. 


\begin{tabular}{|c|c|c|c|c|c|c|}
\hline Vegyület & $\begin{array}{l}-\Delta\left(\Delta \mathbf{H}^{\mathbf{o}}\right) \\
(\mathbf{k J} / \mathbf{m o l})\end{array}$ & $\begin{array}{c}-\Delta\left(\Delta \mathbf{S}^{\mathbf{o}}\right) \\
\left(\mathbf{J} /\left(\mathbf{m o l} \mathbf{l}^{*} \mathbf{K}\right)\right.\end{array}$ & $\begin{array}{c}\text { Korrelációs } \\
\text { koeffíciens } \\
\left(R^{2}\right)\end{array}$ & $\begin{array}{c}-\mathrm{T} x \Delta\left(\Delta \mathbf{S}^{0}\right)_{298 \mathrm{~K}} \\
(\mathrm{~kJ} / \mathrm{mol})\end{array}$ & $\begin{array}{c}-\Delta\left(\Delta \mathbf{G}^{\mathbf{0}}\right) 298 \mathrm{~K} \\
(\mathbf{K} \mathbf{J} / \mathbf{m o l})\end{array}$ & $Q$ \\
\hline \multicolumn{7}{|c|}{$Z W I X(+)$} \\
\hline 2 & 1,3 & 3,1 & 0,998 & 0,9 & 0,4 & 1,4 \\
\hline 6 & 3,2 & 7,8 & 0,997 & 2,3 & 0,9 & 1,4 \\
\hline 9 & 1,8 & 3,6 & 0,985 & 1,1 & 0,7 & 1,7 \\
\hline 11 & 6,0 & 11,9 & 0,989 & 3,5 & 2,5 & 1,7 \\
\hline 16 & 1,7 & 2,9 & 0,981 & 0,9 & 0,8 & 2,0 \\
\hline \multicolumn{7}{|c|}{$Z W I X(-)$} \\
\hline 2 & 2,7 & 6,5 & 0,999 & 1,9 & 0,8 & 1,4 \\
\hline 6 & 3,1 & 7,0 & 0,999 & 2,1 & 1,0 & 1,5 \\
\hline 9 & 3,6 & 7,9 & 0,993 & 2,4 & 1,2 & 1,5 \\
\hline 11 & 5,8 & 12,0 & 0,996 & 3,6 & 2,2 & 1,6 \\
\hline 16 & 2,4 & 4,8 & 0,990 & 1,4 & 1,0 & 1,7 \\
\hline \multicolumn{7}{|c|}{$Q N-A X$} \\
\hline 2 & 3,0 & 6,2 & 0,981 & 1,8 & 1,2 & 1,7 \\
\hline $6^{* *}$ & 2,9 & 8,6 & 0,988 & 2,6 & 0,3 & 1,1 \\
\hline 9 & 6,4 & 17,5 & 0,989 & 5,2 & 1,2 & 1,2 \\
\hline 11 & 8,9 & 24,3 & 0,991 & 7,2 & 1,7 & 1,2 \\
\hline 16 & 9,6 & 23,9 & 0,983 & 7,1 & 2,5 & 1,4 \\
\hline \multicolumn{7}{|c|}{$Q D-A X$} \\
\hline 2 & 3,7 & 8,1 & 0,996 & 2,4 & 1,3 & 1,5 \\
\hline 6 & 2,7 & 7,0 & 0,991 & 2,1 & 0,6 & 1,3 \\
\hline 9 & 8,9 & 25,5 & 0,994 & 7,6 & 1,3 & 1,2 \\
\hline 11 & 10,6 & 30,3 & 0,997 & 9,0 & 1,6 & 1,2 \\
\hline 16 & 15,2 & 41,2 & 0,992 & 12,3 & 2,9 & 1,2 \\
\hline
\end{tabular}

F9 táblázat Termodinamikai paraméterek cinkóna alkaloid alapú állófázisok és $\mathrm{MeOH} / \mathrm{THF}$ mozgófázisrendszer alkalmazása esetén

Kromatográfiás körülmények: kolonna, $Z W I X(+), Z W I X(-), Q N-A X$ és $Q D-A X$; mozgófázis, MeOH/THF $(70 / 30 \mathrm{v} / \mathrm{v})$ és DEA $(25 \mathrm{mM})$ és FA $(50 \mathrm{mM})$; áramlási sebesség, 0,6 $\mathrm{ml}$ perc $^{-1}$; detektálás, 221-280 $\mathrm{nm}$; hömérséklet-tartomány, $5-50{ }^{\circ} \mathrm{C} ; R^{2}$, ln $\alpha$ és $1 / \mathrm{T}$ függvények korrelációs koeffíciense. ${ }^{* *} \mathrm{~T}=5-30^{\circ} \mathrm{C}, Q=$ $\Delta\left(\Delta H^{\circ}\right) / 298 \times \Delta\left(\Delta S^{\circ}\right)$. 


\begin{tabular}{|c|c|c|c|c|c|c|}
\hline \multirow{2}{*}{ Vegyület } & \multirow{2}{*}{$k_{1}, \alpha, R_{s}$} & \multicolumn{5}{|c|}{ Hómérséklet $\left({ }^{\circ} \mathbf{C}\right)$} \\
\hline & & $10^{\circ} \mathrm{C}$ & $20^{\circ} \mathrm{C}$ & $30^{\circ} \mathbf{C}$ & $40{ }^{\circ} \mathrm{C}$ & $50^{\circ} \mathbf{C}$ \\
\hline \multicolumn{7}{|c|}{$I A$} \\
\hline \multirow{3}{*}{21} & $k_{1}$ & 2,09 & 2,03 & 1,83 & 1,67 & 1,56 \\
\hline & $\alpha$ & 1,11 & 1,10 & 1,10 & 1,11 & 1,10 \\
\hline & $\boldsymbol{R}_{S}$ & 0,50 & 0,57 & 0,55 & 0,76 & 0,74 \\
\hline \multirow{3}{*}{23} & $k_{1}$ & 1,78 & 1,60 & 1,46 & 1,33 & 1,40 \\
\hline & $\alpha$ & 1,66 & 1,46 & 1,31 & 1,24 & 1,00 \\
\hline & $\boldsymbol{R}_{S}$ & 1,07 & 0,97 & 0,67 & $<0,2$ & 0,00 \\
\hline \multicolumn{7}{|c|}{$I B$} \\
\hline \multirow{3}{*}{21} & $k_{1}$ & 2,65 & 2,32 & 2,05 & 1,85 & 1,66 \\
\hline & $\alpha$ & 1,21 & 1,22 & 1,22 & 1,22 & 1,22 \\
\hline & $\boldsymbol{R} S$ & 0,78 & 0,93 & 1,17 & 1,13 & 1,25 \\
\hline \multirow{3}{*}{23} & $k_{1}$ & 5,95 & 4,83 & 3,87 & 3,17 & 2,62 \\
\hline & $\alpha$ & 3,20 & 2,88 & 2,43 & 2,13 & 1,93 \\
\hline & $\boldsymbol{R} S$ & 8,95 & 8,74 & 6,94 & 4,39 & 2,56 \\
\hline \multicolumn{7}{|c|}{$I C$} \\
\hline \multirow{3}{*}{21} & $k_{I}$ & 0,56 & 0,55 & 0,54 & 0,53 & 0,53 \\
\hline & $\alpha$ & 3,97 & 3,56 & 3,24 & 2,97 & 2,71 \\
\hline & $\boldsymbol{R}_{S}$ & 5,29 & 5,78 & 6,33 & 6,57 & 6,43 \\
\hline \multirow{3}{*}{23} & $k_{1}$ & 0,66 & 0,62 & 0,59 & 0,56 & 0,46 \\
\hline & $\alpha$ & 1,77 & 1,68 & 1,59 & 1,48 & 1,00 \\
\hline & $\boldsymbol{R}_{S}$ & 1,36 & 0,71 & 1,03 & 0,73 & 0,00 \\
\hline \multicolumn{7}{|c|}{$I D$} \\
\hline \multirow{3}{*}{21} & $k_{1}$ & 0,92 & 0,87 & 0,81 & 0,74 & 0,70 \\
\hline & $\alpha$ & 3,83 & 3,35 & 2,97 & 2,70 & 2,43 \\
\hline & $\boldsymbol{R}_{S}$ & 5,32 & 6,26 & 7,53 & 6,96 & 7,40 \\
\hline \multirow{3}{*}{23} & $k_{1}$ & 0,84 & 0,78 & 0,72 & 0,67 & 0,61 \\
\hline & $\alpha$ & 1,00 & 1,00 & 1,00 & 1,00 & 1,00 \\
\hline & $\boldsymbol{R}_{S}$ & 0,00 & 0,00 & 0,00 & 0,00 & 0,00 \\
\hline \multicolumn{7}{|c|}{$I E$} \\
\hline \multirow{3}{*}{21} & $k_{1}$ & 0,87 & 0,81 & 0,77 & 0,72 & 0,68 \\
\hline & $\alpha$ & 1,26 & 1,24 & 1,22 & 1,20 & 1,18 \\
\hline & $\boldsymbol{R}_{S}$ & 1,09 & 1,24 & 1,21 & 0,94 & 0,84 \\
\hline \multirow{3}{*}{23} & $k_{I}$ & 0,92 & 0,84 & 0,75 & 0,69 & 0,69 \\
\hline & $\alpha$ & 1,93 & 1,85 & 1,75 & 1,65 & 1,00 \\
\hline & $\boldsymbol{R}_{S}$ & 1,49 & 1,14 & 1,60 & 0,80 & 0,00 \\
\hline \multicolumn{7}{|c|}{$I F$} \\
\hline \multirow{3}{*}{21} & $k_{I}$ & 1,10 & 1,06 & 0,97 & 0,94 & 0,93 \\
\hline & $\alpha$ & 1,58 & 1,50 & 1,43 & 1,37 & 1,30 \\
\hline & $\boldsymbol{R}_{S}$ & 1,87 & 1,89 & 1,83 & 1,89 & 1,68 \\
\hline & $k_{1}$ & 1,04 & 0,94 & 0,83 & 0,77 & 0,85 \\
\hline 23 & $\alpha$ & 1,51 & 1,42 & 1,34 & 1,26 & 1,00 \\
\hline & $\boldsymbol{R}_{S}$ & 1,19 & 0,84 & 0,97 & 0,56 & 0,00 \\
\hline & & & $I G$ & & & \\
\hline & $k_{I}$ & 1,41 & 1,30 & 1,19 & 1,12 & 1,06 \\
\hline 21 & $\alpha$ & 1,49 & 1,47 & 1,45 & 1,43 & 1,40 \\
\hline & $\boldsymbol{R}_{S}$ & 1,68 & 2,36 & 2,63 & 2,79 & 2,85 \\
\hline & $k_{1}$ & 1,02 & 0,96 & 0,89 & 0,85 & 0,79 \\
\hline 23 & $\alpha$ & 2,20 & 2,01 & 1,83 & 1,67 & 1,54 \\
\hline & $\boldsymbol{R}_{S}$ & 3,05 & 2,70 & 1,83 & 1,31 & 2,33 \\
\hline
\end{tabular}

F10 táblázat $\mathrm{A}$ kromatográfiás paraméterek változása a hőmérséklet-változtatás függvényében poliszacharid alapú állófázisok esetén normál fázisú mozgófázist alkalmazva Kromatográfiás körülmények: kolonna, $I A, I B, I C, I D, I E, I F$ és $I G$; mozgófázis, $n$-hexán/2-PrOH $(70 / 30 v / v)$ és DEA $(0,1 v \%)$; áramlási sebesség, $1,0 \mathrm{ml}$ perc ${ }^{-1}$; detektálás, $215-250 \mathrm{~nm}$; hömérséklet-tartomány, $5-50{ }^{\circ} \mathrm{C}$. 


\begin{tabular}{|c|c|c|c|c|c|c|}
\hline \multirow{2}{*}{ Vegyület } & \multirow{2}{*}{ Eluens } & \multirow{2}{*}{$k_{1}, \alpha, R_{S}$} & \multicolumn{4}{|c|}{ Hőmérséklet $\left({ }^{\circ} \mathbf{C}\right)$} \\
\hline & & & $20^{\circ} \mathrm{C}$ & $30{ }^{\circ} \mathrm{C}$ & $40^{\circ} \mathrm{C}$ & $50^{\circ} \mathrm{C}$ \\
\hline \multicolumn{7}{|c|}{$Z W I X(+)$} \\
\hline \multirow{3}{*}{17} & \multirow{3}{*}{$\mathrm{a}$} & $k_{1}$ & 15,47 & 15,13 & 14,50 & 13,96 \\
\hline & & $\alpha$ & 1,00 & 1,00 & 1,01 & 1,02 \\
\hline & & $\boldsymbol{R}_{S}$ & 0,00 & 0,00 & $<0,2$ & $<0,2$ \\
\hline \multirow{3}{*}{18} & \multirow{3}{*}{$\mathrm{a}$} & $k_{1}$ & 33,20 & 31,26 & 29,65 & 28,47 \\
\hline & & $\alpha$ & 1,79 & 1,73 & 1,66 & 1,59 \\
\hline & & $\boldsymbol{R}_{S}$ & 9,59 & 11,06 & 10,59 & 10,51 \\
\hline \multirow{3}{*}{26} & \multirow{3}{*}{$\mathrm{b}$} & $k_{1}$ & 3,98 & 4,06 & 4,17 & 4,27 \\
\hline & & $\alpha$ & 1,10 & 1,09 & 1,06 & 1,04 \\
\hline & & $\boldsymbol{R}_{S}$ & 2,46 & 2,23 & 1,74 & 1,32 \\
\hline \multirow{3}{*}{27} & \multirow{3}{*}{$\mathrm{b}$} & $k_{1}$ & 4,11 & 4,22 & 4,37 & 4,49 \\
\hline & & $\alpha$ & 1,09 & 1,08 & 1,06 & 1,05 \\
\hline & & $\boldsymbol{R}_{S}$ & 2,20 & 2,03 & 1,73 & 1,37 \\
\hline \multicolumn{7}{|c|}{$Z W I X(-)$} \\
\hline \multirow{3}{*}{17} & \multirow{3}{*}{$\mathrm{a}$} & $k_{1}$ & 13,64 & 13,30 & 12,98 & 12,56 \\
\hline & & $\alpha$ & 1,35 & 1,33 & 1,31 & 1,29 \\
\hline & & $\boldsymbol{R}_{S}$ & 4,75 & 4,70 & 4,77 & 4,74 \\
\hline \multirow{3}{*}{18} & \multirow{3}{*}{$\mathrm{a}$} & $k_{1}$ & 37,52 & 36,14 & 34,71 & 33,48 \\
\hline & & $\alpha$ & 1,62 & 1,60 & 1,56 & 1,49 \\
\hline & & $\boldsymbol{R}_{S}$ & 8,61 & 9,25 & 9,66 & 9,03 \\
\hline \multirow{3}{*}{26} & \multirow{3}{*}{$\mathrm{b}$} & $k_{1}$ & 5,14 & 5,34 & 5,56 & 5,77 \\
\hline & & $\alpha$ & 1,12 & 1,11 & 1,10 & 1,08 \\
\hline & & $\boldsymbol{R}_{S}$ & 2,45 & 2,55 & 2,47 & 2,02 \\
\hline \multirow{3}{*}{27} & \multirow{3}{*}{$\mathrm{b}$} & $k_{1}$ & 5,11 & 5,43 & 5,84 & 6,24 \\
\hline & & $\alpha$ & 1,16 & 1,15 & 1,13 & 1,12 \\
\hline & & $\boldsymbol{R}_{S}$ & 3,36 & 3,43 & 3,26 & 2,76 \\
\hline
\end{tabular}

F11 táblázat $\mathrm{A}$ kromatográfiás paraméterek változása a hőmérséklet-változtatás függvényében cinkóna alkaloid alapú állófázisok és SFC technika alkalmazása esetén Kromatográfiás körülmények: kolonna, ZWIX(+) és ZWIX(-); mozgófázis, a, $\mathrm{CO}_{2} / \mathrm{MeOH} 70 / 30(v / v)$ és DEA (30 mM) és FA (60 mM), b, $\mathrm{CO}_{2} / \mathrm{MeOH}$ 95/5 ( $\left.v / v\right)$ és DEA (30 mM) és FA (60 mM); áramlási sebesség, 2,0 $\mathrm{ml}$ perc ${ }^{-1}$; detektálás, $215-250 \mathrm{~nm}$; hömérséklet-tartomány, 20-50 ${ }^{\circ} \mathrm{C}$; ellennyomás, 150 bar. 


\begin{tabular}{|c|c|c|c|c|c|}
\hline \multirow{2}{*}{ Vegyület } & \multirow{2}{*}{$k_{1}, \alpha, R_{S}$} & \multicolumn{4}{|c|}{ Hőmérséklet $\left({ }^{\circ} \mathbf{C}\right)$} \\
\hline & & $20^{\circ} \mathrm{C}$ & $30^{\circ} \mathrm{C}$ & $40^{\circ} \mathrm{C}$ & $50^{\circ} \mathrm{C}$ \\
\hline \multicolumn{6}{|c|}{$I A$} \\
\hline \multirow{3}{*}{17} & $k_{1}$ & 0,48 & 0,41 & 0,36 & 0,32 \\
\hline & $\alpha$ & 1,18 & 1,19 & 1,19 & 1,20 \\
\hline & $\boldsymbol{R}_{S}$ & 0,85 & 1,08 & 0,94 & 1,09 \\
\hline \multirow{3}{*}{18} & $k_{1}$ & 1,06 & 0,88 & 0,76 & 0,68 \\
\hline & $\alpha$ & 1,96 & 1,66 & 1,38 & 1,10 \\
\hline & $\boldsymbol{R}_{S}$ & 4,05 & 4,21 & 3,2 & 1,03 \\
\hline \multirow{3}{*}{19} & $k_{1}$ & 0,38 & 0,34 & 0,31 & 0,29 \\
\hline & $\alpha$ & 1,00 & 1,00 & 1,00 & 1,00 \\
\hline & $\boldsymbol{R}_{S}$ & 0,00 & 0,00 & 0,00 & 0,00 \\
\hline \multirow{3}{*}{20} & $k_{1}$ & 1,14 & 0,95 & 0,82 & 0,73 \\
\hline & $\alpha$ & 6,29 & 4,21 & 2,71 & 1,59 \\
\hline & $\boldsymbol{R}_{S}$ & 9,13 & 10,34 & 9,53 & 3,18 \\
\hline \multirow{3}{*}{21} & $k_{1}$ & 0,69 & 0,65 & 0,64 & 0,61 \\
\hline & $\alpha$ & 1,42 & 1,37 & 1,31 & 1,24 \\
\hline & $\boldsymbol{R}_{S}$ & 1,29 & 1,55 & 1,71 & 1,33 \\
\hline \multirow{3}{*}{22} & $k_{1}$ & 1,35 & 1,17 & 1,01 & 0,94 \\
\hline & $\alpha$ & 1,81 & 1,50 & 1,26 & 1,00 \\
\hline & $\boldsymbol{R}_{S}$ & 1,73 & 1,99 & 1,75 & 0,00 \\
\hline \multirow{3}{*}{26} & $k_{1}$ & 0,73 & 0,58 & 0,47 & 0,36 \\
\hline & $\alpha$ & 1,24 & 1,22 & 1,21 & 1,20 \\
\hline & $\boldsymbol{R}_{S}$ & 3,11 & 2,78 & 2,38 & 1,84 \\
\hline \multirow{3}{*}{27} & $k_{1}$ & 0,98 & 0,80 & 0,66 & 0,52 \\
\hline & $\alpha$ & 1,13 & 1,12 & 1,10 & 1,09 \\
\hline & $\boldsymbol{R}_{S}$ & 1,96 & 1,77 & 1,52 & 1,06 \\
\hline \multirow{3}{*}{28} & $k_{1}$ & 1,06 & 0,85 & 0,68 & 0,53 \\
\hline & $\alpha$ & 1,29 & 1,25 & 1,23 & 1,20 \\
\hline & $\boldsymbol{R}_{S}$ & 4,04 & 3,68 & 3,16 & 2,33 \\
\hline \multirow{3}{*}{29} & $k_{1}$ & 0,73 & 0,58 & 0,47 & 0,36 \\
\hline & $\alpha$ & 1,24 & 1,22 & 1,21 & 1,20 \\
\hline & $\boldsymbol{R}_{S}$ & 3,10 & 2,75 & 2,35 & 1,82 \\
\hline
\end{tabular}

F12 táblázat $\mathrm{A}$ kromatográfiás paraméterek változása a hőmérséklet-változtatás függvényében poliszacharid alapú állófázisok és SFC technika alkalmazása esetén Kromatográfiás körülmények: kolonna, $I A$; mozgófázis, $\mathrm{CO}_{2} / \mathrm{MeOH} 50 / 50(v / v)$ és DEA $(20 \mathrm{mM})$; áramlási sebesség, 2,0 ml perc ${ }^{-1}$; detektálás, $215-250 \mathrm{~nm}$; hömérséklet-tartomány, $20-50{ }^{\circ} \mathrm{C}$; ellennyomás, 150 bar. 


\begin{tabular}{|c|c|c|c|c|c|}
\hline \multirow{2}{*}{ Vegyület } & \multirow{2}{*}{$k_{1}, \alpha, R_{S}$} & \multicolumn{4}{|c|}{ Hőmérséklet $\left({ }^{\circ} \mathbf{C}\right)$} \\
\hline & & $20^{\circ} \mathrm{C}$ & $30{ }^{\circ} \mathrm{C}$ & $40^{\circ} \mathrm{C}$ & $50^{\circ} \mathrm{C}$ \\
\hline \multicolumn{6}{|c|}{$I B$} \\
\hline \multirow{3}{*}{17} & $k_{1}$ & 1,00 & 0,83 & 0,72 & 0,64 \\
\hline & $\alpha$ & 1,09 & 1,08 & 1,06 & 1,05 \\
\hline & $\boldsymbol{R}_{S}$ & 0,74 & 0,45 & 0,34 & 0,23 \\
\hline \multirow{3}{*}{18} & $k_{1}$ & 2,33 & 1,98 & 1,63 & 1,40 \\
\hline & $\alpha$ & 1,04 & 1,00 & 1,00 & 1,00 \\
\hline & $\boldsymbol{R}_{S}$ & 0,23 & 0,00 & 0,00 & 0,00 \\
\hline \multirow{3}{*}{19} & $k_{1}$ & 0,81 & 0,68 & 0,59 & 0,52 \\
\hline & $\alpha$ & 1,00 & 1,00 & 1,00 & 1,00 \\
\hline & $\boldsymbol{R}_{S}$ & 0,00 & 0,00 & 0,00 & 0,00 \\
\hline \multirow{3}{*}{20} & $k_{1}$ & 1,87 & 1,55 & 1,30 & 1,12 \\
\hline & $\alpha$ & 1,29 & 1,25 & 1,20 & 1,16 \\
\hline & $\boldsymbol{R}_{S}$ & 1,90 & 2,26 & 1,95 & 1,63 \\
\hline \multirow{3}{*}{21} & $k_{1}$ & 1,60 & 1,33 & 1,17 & 1,06 \\
\hline & $\alpha$ & 1,00 & 1,00 & 1,00 & 1,00 \\
\hline & $\boldsymbol{R}_{S}$ & 0,00 & 0,00 & 0,00 & 0,00 \\
\hline \multirow{3}{*}{22} & $k_{1}$ & 2,88 & 2,35 & 1,98 & 1,71 \\
\hline & $\alpha$ & 1,11 & 1,14 & 1,16 & 1,19 \\
\hline & $\boldsymbol{R}_{S}$ & 0,64 & 1,03 & 1,40 & 1,59 \\
\hline \multirow{3}{*}{26} & $k_{1}$ & 0,43 & 0,36 & 0,30 & 0,25 \\
\hline & $\alpha$ & 1,27 & 1,26 & 1,24 & 1,24 \\
\hline & $\boldsymbol{R}_{S}$ & 2,72 & 2,37 & 2,02 & 1,70 \\
\hline \multirow{3}{*}{27} & $k_{1}$ & 0,48 & 0,42 & 0,35 & 0,29 \\
\hline & $\alpha$ & 1,25 & 1,24 & 1,23 & 1,22 \\
\hline & $\boldsymbol{R}_{S}$ & 2,72 & 2,43 & 2,09 & 1,79 \\
\hline \multirow{3}{*}{28} & $k_{1}$ & 0,55 & 0,48 & 0,39 & 0,32 \\
\hline & $\alpha$ & 1,25 & 1,23 & 1,22 & 1,21 \\
\hline & $\boldsymbol{R}_{S}$ & 2,85 & 2,55 & 2,20 & 1,89 \\
\hline \multirow{3}{*}{29} & $k_{1}$ & 0,42 & 0,37 & 0,30 & 0,25 \\
\hline & $\alpha$ & 1,27 & 1,26 & 1,24 & 1,24 \\
\hline & $\boldsymbol{R}_{S}$ & 2,69 & 2,34 & 2,02 & 1,66 \\
\hline
\end{tabular}

F13 táblázat $\mathrm{A}$ kromatográfiás paraméterek változása a hőmérséklet-változtatás függvényében poliszacharid alapú állófázisok és SFC technika alkalmazása esetén Kromatográfiás körülmények: kolonna, $I B$; mozgófázis, $\mathrm{CO}_{2} / \mathrm{MeOH} 50 / 50(v / v)$ és DEA $(20 \mathrm{mM})$; áramlási sebesség, 2,0 ml perc ${ }^{-1}$; detektálás, $215-250 \mathrm{~nm}$; hömérséklet-tartomány, $20-50{ }^{\circ} \mathrm{C}$; ellennyomás, 150 bar. 


\begin{tabular}{|c|c|c|c|c|c|}
\hline \multirow{2}{*}{ Vegyület } & \multirow{2}{*}{$k_{1}, \alpha, R_{S}$} & \multicolumn{4}{|c|}{ Hőmérséklet $\left({ }^{\circ} \mathbf{C}\right)$} \\
\hline & & $20^{\circ} \mathrm{C}$ & $30^{\circ} \mathrm{C}$ & $40^{\circ} \mathrm{C}$ & $50^{\circ} \mathrm{C}$ \\
\hline \multicolumn{6}{|c|}{$I C$} \\
\hline \multirow{3}{*}{17} & $k_{1}$ & 0,34 & 0,31 & 0,29 & 0,27 \\
\hline & $\alpha$ & 1,00 & 1,00 & 1,00 & 1,00 \\
\hline & $\boldsymbol{R}_{S}$ & 0,00 & 0,00 & 0,00 & 0,00 \\
\hline \multirow{3}{*}{18} & $k_{1}$ & 1,70 & 1,53 & 1,42 & 1,37 \\
\hline & $\alpha$ & 2,52 & 2,44 & 2,37 & 2,31 \\
\hline & $\boldsymbol{R}_{S}$ & 10,01 & 11,01 & 11,42 & 12,49 \\
\hline \multirow{3}{*}{19} & $k_{1}$ & 0,30 & 0,27 & 0,25 & 0,23 \\
\hline & $\alpha$ & 1,00 & 1,00 & 1,00 & 1,00 \\
\hline & $\boldsymbol{R}_{S}$ & 0,00 & 0,00 & 0,00 & 0,00 \\
\hline \multirow{3}{*}{20} & $k_{1}$ & 1,63 & 1,51 & 1,43 & 1,40 \\
\hline & $\alpha$ & 1,85 & 1,81 & 1,77 & 1,74 \\
\hline & $\boldsymbol{R}_{S}$ & 6,31 & 6,73 & 7,12 & 7,47 \\
\hline \multirow{3}{*}{21} & $k_{1}$ & 0,23 & 0,22 & 0,22 & 0,24 \\
\hline & $\alpha$ & 1,00 & 1,00 & 1,00 & 1,00 \\
\hline & $\boldsymbol{R}_{S}$ & 0,00 & 0,00 & 0,00 & 0,00 \\
\hline \multirow{3}{*}{22} & $k_{1}$ & 1,36 & 1,27 & 1,23 & 1,22 \\
\hline & $\alpha$ & 2,41 & 2,34 & 2,28 & 2,22 \\
\hline & $\boldsymbol{R}_{S}$ & 6,80 & 7,78 & 8,51 & 9,27 \\
\hline \multirow{3}{*}{26} & $k_{1}$ & 0,23 & 0,19 & 0,15 & 0,13 \\
\hline & $\alpha$ & 1,37 & 1,39 & 1,41 & 1,42 \\
\hline & $\boldsymbol{R}_{S}$ & 1,43 & 1,32 & 1,31 & 1,29 \\
\hline \multirow{3}{*}{27} & $k_{1}$ & 0,29 & 0,24 & 0,22 & 0,19 \\
\hline & $\alpha$ & 1,26 & 1,24 & 1,23 & 1,22 \\
\hline & $\boldsymbol{R}_{S}$ & 1,23 & 1,14 & 0,82 & 0,65 \\
\hline \multirow{3}{*}{28} & $k_{1}$ & 0,35 & 0,30 & 0,26 & 0,23 \\
\hline & $\alpha$ & 1,39 & 1,38 & 1,36 & 1,35 \\
\hline & $\boldsymbol{R}_{S}$ & 2,72 & 2,53 & 2,36 & 2,17 \\
\hline \multirow{3}{*}{29} & $k_{1}$ & 0,23 & 0,19 & 0,16 & 0,13 \\
\hline & $\alpha$ & 1,37 & 1,39 & 1,40 & 1,42 \\
\hline & $\boldsymbol{R}_{S}$ & 1,44 & 1,48 & 1,38 & 1,35 \\
\hline
\end{tabular}

F14 táblázat $\mathrm{A}$ kromatográfiás paraméterek változása a hőmérséklet-változtatás függvényében poliszacharid alapú állófázisok és SFC technika alkalmazása esetén Kromatográfiás körülmények: kolonna, $I C$; mozgófázis, $\mathrm{CO}_{2} / \mathrm{MeOH} 50 / 50(v / v)$ és DEA $(20 \mathrm{mM})$; áramlási sebesség, 2,0 ml perc ${ }^{-1}$; detektálás, $215-250 \mathrm{~nm}$; hömérséklet-tartomány, $20-50{ }^{\circ} \mathrm{C}$; ellennyomás, 150 bar. 


\begin{tabular}{|c|c|c|c|c|c|}
\hline \multirow{2}{*}{ Vegyület } & \multirow{2}{*}{$k_{1}, \alpha, R_{S}$} & \multicolumn{4}{|c|}{ Hőmérséklet $\left({ }^{\circ} \mathbf{C}\right)$} \\
\hline & & $20^{\circ} \mathrm{C}$ & $30{ }^{\circ} \mathrm{C}$ & $40^{\circ} \mathrm{C}$ & $50^{\circ} \mathrm{C}$ \\
\hline \multicolumn{6}{|c|}{$I E$} \\
\hline \multirow{3}{*}{17} & $k_{1}$ & 1,05 & 0,88 & 0,74 & 0,63 \\
\hline & $\alpha$ & 1,03 & 1,05 & 1,06 & 1,08 \\
\hline & $\boldsymbol{R}_{S}$ & 0,12 & 0,26 & 0,37 & 0,49 \\
\hline \multirow{3}{*}{18} & $k_{1}$ & 3,55 & 2,95 & 2,47 & 2,13 \\
\hline & $\alpha$ & 1,21 & 1,20 & 1,19 & 1,19 \\
\hline & $\boldsymbol{R}_{S}$ & 1,78 & 2,09 & 2,41 & 2,46 \\
\hline \multirow{3}{*}{19} & $k_{1}$ & 1,13 & 0,92 & 0,75 & 0,64 \\
\hline & $\alpha$ & 1,07 & 1,08 & 1,10 & 1,11 \\
\hline & $\boldsymbol{R}_{S}$ & 0,15 & 0,20 & 0,26 & 0,43 \\
\hline \multirow{3}{*}{20} & $k_{1}$ & 4,08 & 3,53 & 3,05 & 2,69 \\
\hline & $\alpha$ & 1,36 & 1,32 & 1,27 & 1,24 \\
\hline & $\boldsymbol{R}_{S}$ & 2,71 & 2,96 & 2,88 & 2,83 \\
\hline \multirow{3}{*}{21} & $k_{1}$ & 0,71 & 0,63 & 0,55 & 0,50 \\
\hline & $\alpha$ & 1,25 & 1,22 & 1,20 & 1,18 \\
\hline & $\boldsymbol{R}_{S}$ & 1,47 & 1,38 & 1,14 & 0,90 \\
\hline \multirow{3}{*}{22} & $k_{1}$ & 2,62 & 2,30 & 2,01 & 1,80 \\
\hline & $\alpha$ & 1,79 & 1,72 & 1,64 & 1,58 \\
\hline & $\boldsymbol{R}_{S}$ & 4,76 & 4,85 & 5,09 & 4,99 \\
\hline \multirow{3}{*}{26} & $k_{1}$ & 0,36 & 0,28 & 0,22 & 0,18 \\
\hline & $\alpha$ & 1,31 & 1,32 & 1,33 & 1,34 \\
\hline & $\boldsymbol{R}_{S}$ & 2,48 & 2,30 & 1,97 & 1,74 \\
\hline \multirow{3}{*}{27} & $k_{1}$ & 0,37 & 0,31 & 0,25 & 0,21 \\
\hline & $\alpha$ & 1,28 & 1,30 & 1,31 & 1,32 \\
\hline & $\boldsymbol{R}_{S}$ & 2,10 & 2,14 & 2,11 & 1,96 \\
\hline \multirow{3}{*}{28} & $k_{1}$ & 0,54 & 0,45 & 0,37 & 0,30 \\
\hline & $\alpha$ & 1,32 & 1,32 & 1,32 & 1,32 \\
\hline & $\boldsymbol{R}_{S}$ & 3,07 & 2,99 & 2,80 & 2,53 \\
\hline \multirow{3}{*}{29} & $k_{1}$ & 0,36 & 0,28 & 0,22 & 0,17 \\
\hline & $\alpha$ & 1,31 & 1,32 & 1,33 & 1,34 \\
\hline & $\boldsymbol{R}_{S}$ & 2,50 & 2,25 & 1,97 & 1,72 \\
\hline
\end{tabular}

F15 táblázat $\mathrm{A}$ kromatográfiás paraméterek változása a hőmérséklet-változtatás függvényében poliszacharid alapú állófázisok és SFC technika alkalmazása esetén Kromatográfiás körülmények: kolonna, $I E$; mozgófázis, $\mathrm{CO}_{2} / \mathrm{MeOH} 50 / 50(v / v)$ és DEA $(20 \mathrm{mM})$; áramlási sebesség, 2,0 ml perc ${ }^{-1}$; detektálás, $215-250 \mathrm{~nm}$; hömérséklet-tartomány, $20-50{ }^{\circ} \mathrm{C}$; ellennyomás, 150 bar. 

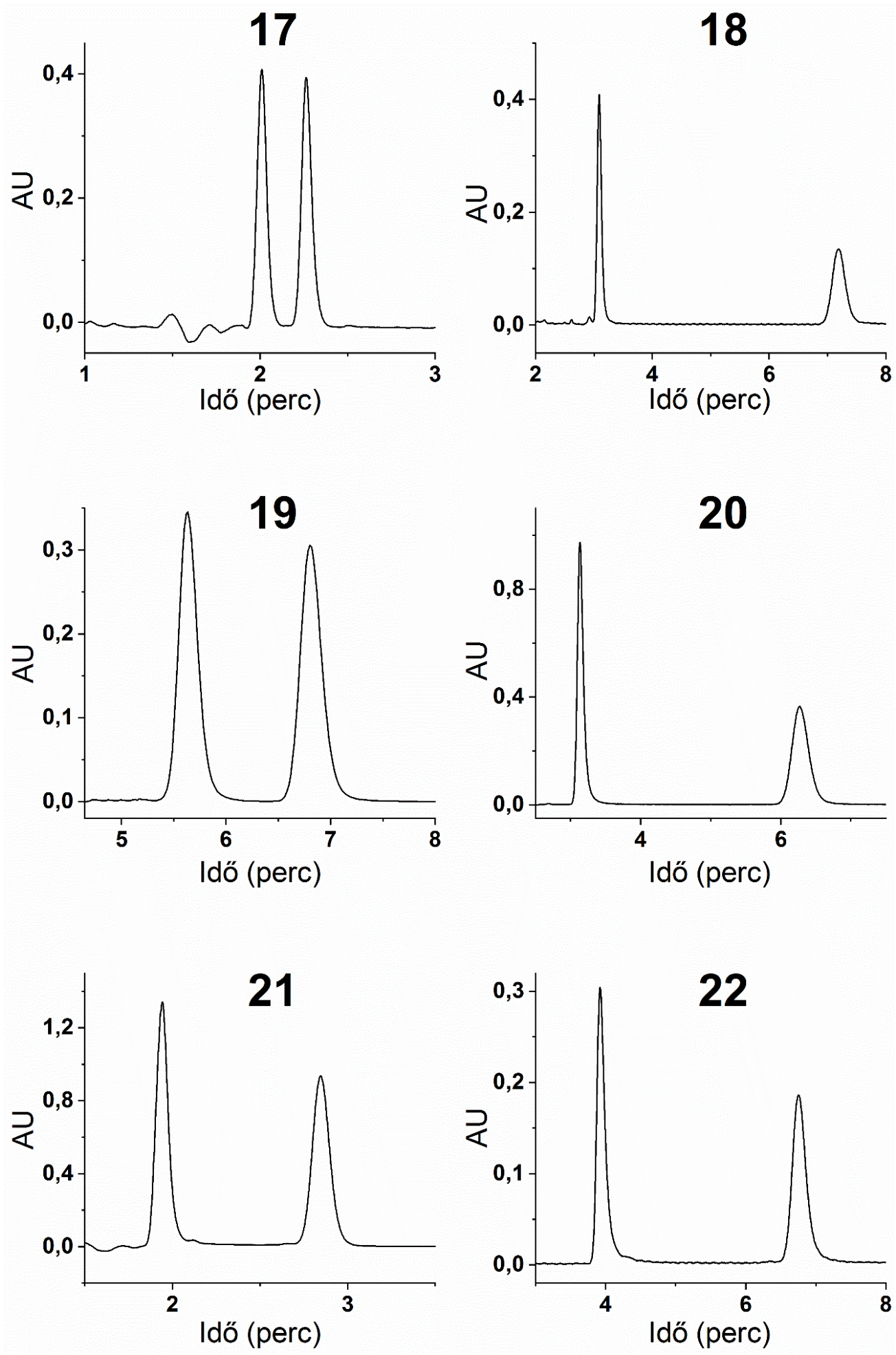

F10 ábra Bázikus és amfolit indol analógok válogatott kromatogramjai

Kromatográfiás körülmények: kolonna, $Z W I X(-) 18$ esetén, $I G$ 17, 19, 21 esetén, IC 20 és 22 esetén; mozgófázis, $\mathrm{CO}_{2} / \mathrm{MeOH} 70 / 30(v / v)$ és DEA $(30 \mathrm{mM})$ és FA $(60 \mathrm{mM}) 18$ esetén, $\mathrm{CO}_{2} / \mathrm{MeOH} 50 / 50(v / v)$ és DEA $(20 \mathrm{mM})$ 17, 20, 21 és 22 esetén, $n$-hexán/2-PrOH $(80 / 20 v / v)$ és DEA $(0,1 v \%) 19$ esetén; áramlási sebesség, 2,0 ml perc ${ }^{-1} \mathbf{1 7}, \mathbf{1 8}, \mathbf{2 0}, 21$ és 22 esetén, $1,0 \mathrm{ml} \mathrm{perc}^{-1} 19$ esetén; detektálás $215-250 \mathrm{~nm}$, hőmérséklet, $40{ }^{\circ} \mathrm{C} \mathbf{1 7}, \mathbf{1 8}, \mathbf{2 0}, 21$ és 22 esetén, szobahőmérséklet 19 esetén; SFC ellennyomás 150 bar. 

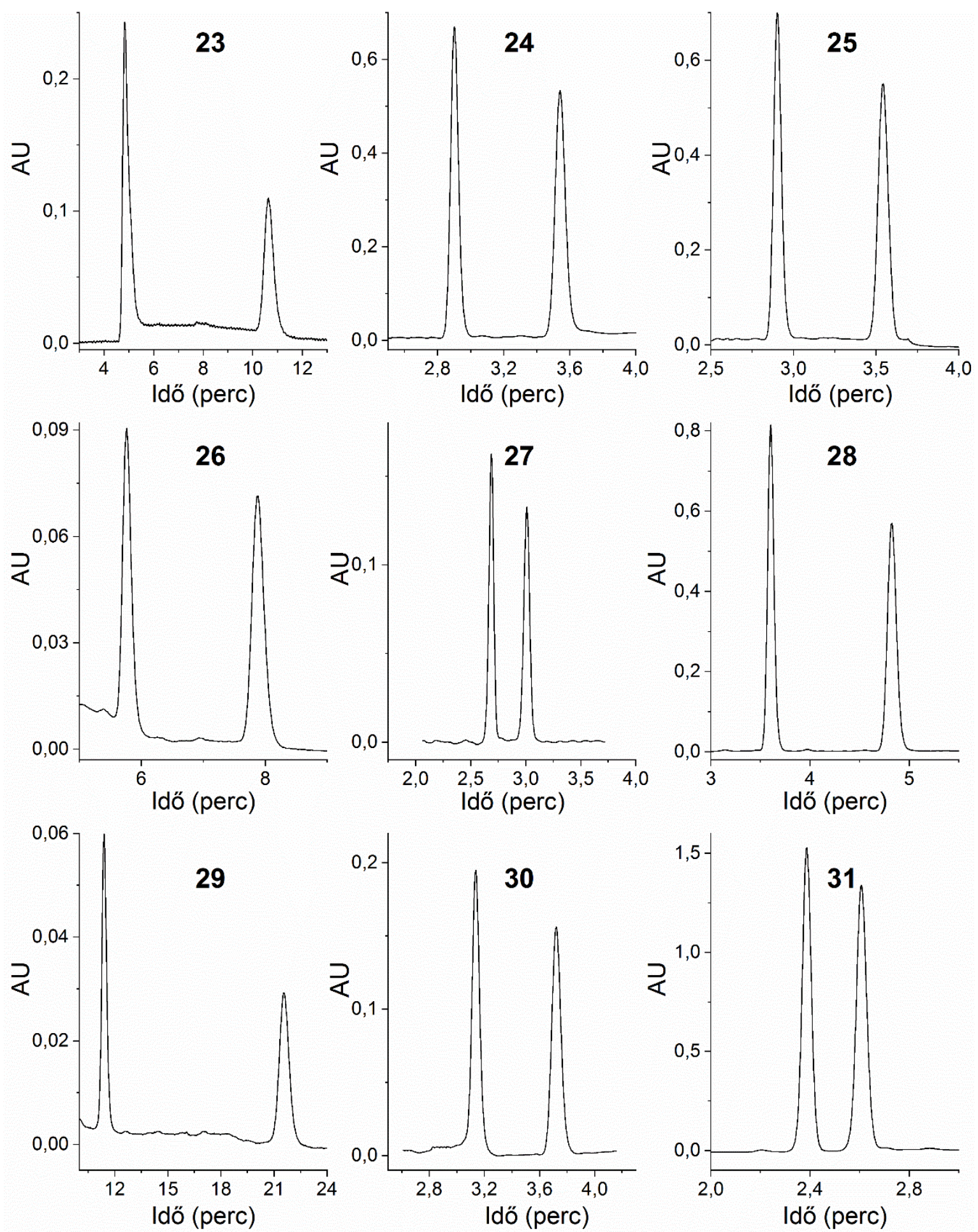

F11 ábra 1,2,3,4-tetrahidroizokinolin és 1-naftol származékok válogatott kromatogramjai

Kromatográfiás körülmények: kolonna, $I G$ 23, 24, 25, 26, 28 és 30 esetén, IF 27 esetén, ID 29 esetén, IE 31 esetén; mozgófázis, $\mathrm{CO}_{2} / \mathrm{MeOH} 50 / 50(v / v)$ és DEA $(20 \mathrm{mM}) \mathbf{2 3}, \mathbf{2 4}, \mathbf{2 5}, \mathbf{2 7}, \mathbf{2 8}, \mathbf{3 0}$ és 31 esetén, $n$-hexán/2PrOH $(80 / 20 v / v)$ és DEA $(0,1 v \%) 26$ és 29 esetén; áramlási sebesség, 2, $0 \mathrm{ml} \mathrm{perc}^{-1} \mathbf{2 3}, \mathbf{2 4}, \mathbf{2 5}, \mathbf{2 7}, \mathbf{2 8}, \mathbf{3 0}$ és 31 esetén, $1,0 \mathrm{ml}$ perc $^{-1} \mathbf{2 6}$ és 29 esetén; detektálás $215-250 \mathrm{~nm}$, hömérséklet, $40^{\circ} \mathrm{C} \mathbf{2 3}, \mathbf{2 4}, \mathbf{2 5}, \mathbf{2 7}, \mathbf{2 8}, 30$ és 31 esetén, szobahömérséklet 26 és 29 esetén; SFC ellennyomás 150 bar. 